UNIVERSIDADE ESTADUAL PAULISTA “JÚLIO DE MESQUITA FILHO” INSTITUTO DE BIOCIÊNCIAS, LETRAS E CIÊNCIAS EXATAS

LILIANE SANTANA

MOTIVAÇÕES FUNCIONAIS DA GRADAÇÃO ENTRE CONSTRUÇÕES ENCAIXADAS NOMINAIS E VERBAIS

SÃO JOSÉ DO RIO PRETO 


\section{MOTIVAÇÕES FUNCIONAIS DA GRADAÇÃO ENTRE CONSTRUÇÕES ENCAIXADAS NOMINAIS E VERBAIS}

Tese de Doutorado apresentada ao Programa de Pósgraduação em Estudos Linguísticos, do Instituto de Biociências, Letras e Ciências Exatas - UNESP/São José do Rio Preto, como requisito para obtenção do título de Doutor em Estudos Linguísticos.

Área de Concentração: Análise Linguística

Orientador: Prof. Dr. Roberto Gomes Camacho

Bolsas: FAPESP (Processo no. 06/50145-1)

CAPES (Processo n ${ }^{\circ} .4498-07-0$ )

São José do Rio Preto 
Santana, Liliane.

Motivações funcionais da gradação entre construções encaixadas nominais e verbais / Liliane Santana. - São José do Rio Preto : [s.n.], 2010 .

261 f. : il. ; $30 \mathrm{~cm}$.

Orientador: Roberto Gomes Camacho

Tese (doutorado) - Universidade Estadual Paulista, Instituto de

Biociências, Letras e Ciências Exatas

1. Linguística. 2. Funcionalismo (Linguística). 3. Análise linguística (Linguística). 4. Gramática funcional. 5. Oração completiva. I. Camacho, Roberto Gomes. II. Universidade Estadual Paulista, Instituto de Biociências, Letras e Ciências Exatas. III. Título.

CDU $-81^{\prime} 1$

Ficha catalográfica elaborada pela Biblioteca do IBILCE

Campus de São José do Rio Preto - UNESP 


\section{LILIANE SANTANA}

\section{MOTIVAÇÕES FUNCIONAIS DA GRADAÇÃO ENTRE CONSTRUÇÕES ENCAIXADAS NOMINAIS E VERBAIS}

Tese de Doutorado apresentada ao Programa de Pósgraduação em Estudos Linguísticos, do Instituto de Biociências, Letras e Ciências Exatas - UNESP/São José do Rio Preto, como requisito para obtenção do título de Doutor em Estudos Linguísticos.

Área de Concentração: Análise Linguística

Orientador: Prof. Dr. Roberto Gomes Camacho

Bolsas: FAPESP (Processo $n^{\circ}$. 06/50145-1); CAPES (Processo no. 4498-07-0)

Data da aprovação: 18/01/2010

Membros componentes da Banca Examinadora:

Prof. Dr. Roberto Gomes Camacho - Orientador

UNESP - Universidade Estadual Paulista

Prof. Dr. Sebastião Carlos Leite Gonçalves

UNESP - Universidade Estadual Paulista

Profa. Dra. Cláudia Nívea Roncarati de Souza

UFF - Universidade Federal Fluminense

Profa. Dra. Flávia Bezerra de Menezes Hirata-Vale

UFSCar - Universidade Federal de São Carlos

Profa. Dra. Vânia Cristina Casseb Galvão

UFG - Universidade Federal de Goiás 


\section{AGRADECIMENTOS}

Ao Roberto, pela disposição em me orientar com paciência e resignação durante os mais de oito anos em que trabalhamos juntos, pelos ensinamentos, pelo incentivo, pela dedicação, pela

cumplicidade e pela amizade. Durante a dura caminhada, foi com ele que compartilhei os momentos de completa euforia com a tese e, também, os momentos de descontentamento. Foi dele que ouvi que, para um pesquisador consciente, a insatisfação está incluída no pacote e ajuda a encontrar as melhores soluções no final. Se, ao término deste trabalho (e dos outros), encontramos as melhores soluções, certamente, ele é o maior responsável;

Ao Lachlan, supervisor de meu estágio no ILTEC (Lisboa/Portugal), pela dedicação, pela atenção e pela disponibilidade em discutir vários pontos deste trabalho. Se suas explicações não se encontram nesta tese ou encontram-se de forma torta, a responsabilidade é toda minha;

Aos professores Cláudia Nívea Roncarati de Souza (UFF), Flávia Bezerra de Menezes Hirata-Vale (UFSCar), Vânia Cristina Casseb Galvão (UFG) e Sebastião Carlos Leite Gonçalves (UNESP), membros da Banca Examinadora desta tese, pelas críticas e sugestões que me permitiram aparar as arestas e aprimorar a forma e o conteúdo deste trabalho;

Aos colegas do Grupo de Pesquisa em Gramática Funcional, pelas discussões de aspectos importantes para o desenvolvimento deste trabalho e também de minha formação como pesquisadora;

Aos professores Maria Helena Mira Mateus e Carlos A. M. Gouveia, por me acolherem no seio da família iltequiana e pela atenção que me dispensaram durante a realização do estágio no ILTEC. Meu carinho à Isabel, pela presteza com que me atendeu, ao José Pedro, por salvar o meu computador, ao Sóstenes e à Marta, meus companheiros de sala, e, especialmente, aos brazucas Roberto e Mário, pela conversa fiada e sempre muito animada;

Aos meus pais, Valter e Neuza, e à minha irmã, Ana Maria, espectadores atentos de minha trajetória, por estarem sempre ao meu lado, desejando vivamente o meu sucesso;

Aos pequenos Amanda e Pedro, pelos momentos de pura bagunça, diversão e enorme carinho, sem os quais, certamente, a labuta teria sido muitíssimo mais dura; 
Aos meus amigos e companheiros de vida e de luta, João Paulo, Chá, Thi, Claytão, Vá,

Boizão, Fer, Ito, Lê, Carol, Fino, Beta, Melo e Leo, pela torcida constante e, principalmente, pelo sonho conjunto;

À FAPESP - Fundação de Amparo à Pesquisa do Estado de São Paulo, pelo apoio financeiro, sem o qual seria difícil a conclusão desta tese;

À CAPES - Coordenação de Aperfeiçoamento de Pessoal do Ensino Superior, pelo apoio financeiro que possibilitou a realização do estágio no ILTEC;

A todos aqueles que, direta ou indiretamente, contribuíram para o desenvolvimento deste trabalho, meu sincero reconhecimento. 
SANTANA, L. Motivações funcionais da gradação entre construções encaixadas nominais e verbais. 2010. 261 f. Tese (Doutorado em Estudos Linguísticos) - Instituto de Biociências, Letras e Ciências Exatas, Universidade Estadual Paulista, São José do Rio Preto, 2010.

\section{RESUMO}

O principal objetivo desta tese é o estudo da variação escalar entre construções verbais e nominais que figuram como complemento de orações hierarquicamente superiores, isto é, orações completivas finitas plenamente desenvolvidas e orações completivas não-finitas com um verbo infinitivo ou com uma nominalização como núcleo. Essas possibilidades de variação fornecem um conjunto de construções alternativas, cuja seleção pode depender de fatores funcionais, embora não exclusivamente. A variação entre construções mais nominais e construções mais verbais e as consequências dela decorrentes são razões que justificam plenamente uma investigação criteriosa das motivações semânticas que regem o funcionamento das construções encaixadas completivas, mediante a atuação dos princípios funcionais de iconicidade e economia (HAIMAN, 1983; CRISTOFARO, 2003) na relação entre a semântica do predicado encaixador de complemento e a codificação morfossintática do predicado encaixado. A principal proposição que conduz a investigação é a de que, para a seleção dos diferentes tipos de complemento, existe uma relação de integração semântica (GIVÓN, 1980, 1990) entre construções completivas e a categoria semântica do predicado encaixador, de modo que a semântica do predicado encaixador é altamente relevante para determinar a categoria morfossintática das predicações dependentes. A relação de gradação entre maior ou menor grau de sentencialidade (LEHMANN, 1988), que se correlaciona ao grau de nominalidade da construção dependente, está vinculada ao nível e à camada de organização estrutural definidos pela Gramática Discursivo-Funcional (HENGEVELD; MACKENZIE, 2008) nos seguintes termos: quanto mais baixa a camada de representação do complemento tanto maior o grau de integração semântica entre o predicado da oração encaixadora e o predicado da oração completiva.

Palavras-chave: predicados encaixadores de complemento, oração completiva, integração semântica. 
SANTANA, L. Functional motivations for the gradiency between nominal and verbal embedded constructions. 2010. 261 f. PhD Thesis ( $\mathrm{PhD}$ degree in Linguistic Studies) Instituto de Biociências, Letras e Ciências Exatas, Universidade Estadual Paulista, São José do Rio Preto, 2010.

\begin{abstract}
The aim of this thesis is to investigate the scalar variation between verbal and nominal constructions which function as complements of hierarchically higher clauses, i.e., finite complement clauses which are fully developed, and non-finite complement clauses which are headed by an infinitive verb or a nominalization. This range of variation provides a set of alternative constructions whose selection may, though not exclusively, depend on functional factors. The variation between more nominal and more verbal constructions and its consequences fully justifies a rigorous investigation of the semantic motivations which govern how embedded complement clauses actually function, by means of the functional principles of iconicity and economy (HAIMAN, 1983; CRISTOFARO, 2003) on the relationship between the semantics of the complement taking predicate and the morphosyntactic encoding of the embedded predicate. The main tenet underlying this investigation is that (i) sorting out different types of complement predicates requires a relation of semantic integration (GIVÓN, 1980, 1990) between complement clause and the semantic category of the complement taking predicate and (ii) such relation is, therefore, highly relevant to determine the morphosyntactic encoding of the dependent predications. The gradient relationship between balancing and deranking sentences, which is correlated to the degree of nominality or sentenciality of the dependent construction (LEHMANN, 1988), is associated with the structural organization of levels and layers defined by Functional Discourse Grammar (HENGEVELD; MACKENZIE, 2008) as follows: the lower the representation level of the complement the higher the degree of semantic integration between the complement taking predicate and the predicate of the embedded clause.
\end{abstract}

Keywords: complement taking predicate; complement clause; semantic integration. 


\section{LISTA DE FIGURAS, QUADROS E GRÁFICOS}

\section{FIGURAS}

Figura 1-1: Dessentencialização .............................................................. 40

Figura 1-2: $\quad$ Funcionalismo e formalismo: autonomia e formalização .................. 50

Figura 2-1: $\quad$ Dessentencialização ................................................................. 65

Figura 2-2: $\quad$ Tipos de construções encaixadas .................................................. 88

Figura 3-1: GDF como parte de uma teoria de interação verbal ........................... 109

Figura 3-2: $\quad$ Arquitetura geral da GDF ..................................................... 110

Figura 6-1: $\quad$ Escala de predicados encaixadores ................................................. 235

\section{QUADROS}

Quadro 1-1: $\quad$ Caracterização do modo verbal da completiva ......................................... 30

Quadro 1-2: $\quad$ Tripartição de orações complexas .................................................................. 43

Quadro 2-1: $\quad$ Hierarquia da ligação ................................................................. 63

Quadro 2-2: $\quad$ Integração semântica .............................................................. 70

Quadro 2-3: Predicados encaixadores segundo Givón (1980) e Cristofaro (2003)/Noonan $(1985)$................................................................. 76

Quadro 2-4: Predicados encaixadores segundo Givón (1980), Cristofaro (2003)/Noonan (1985) e Dik (1997b) ............................................. 77

Quadro 2-5: Comparação entre tipos de predicados encaixadores segundo Dixon (2006), Givón (1980), Cristofaro (2003)/Noonan (1985) e Dik (1997b) ...... 79

Quadro 2-6: Correspondências entre classes de palavras lexicais e gramaticais ..... 83

Quadro 2-7: $\quad$ Tipos de predicados encaixadores considerados para análise ............ 84

Quadro 2-8: $\quad$ Tipos de complementos .......................................................... 90

Quadro 3-1: Categorias semânticas .................................................................. 116

Quadro 3-2: $\quad$ Categorias semânticas …............................................................. 118 
Quadro 3-3: $\quad$ Classificação de orações completivas ................................................ 130

Quadro 5-1: $\quad$ Tipos de predicados encaixadores considerados para análise ............. 158

Quadro 5-2: $\quad$ Tipo de predicados encaixadores e tipo de completiva ..................... 213

Quadro 6-1: $\quad$ Hierarquia da integração semântica ……........................................... 240

Quadro 6-2: $\quad$ Resultados obtidos em comparação às predições de Givón (1980) .... 242

Quadro 6-3: $\quad$ Tipo de entidade e forma assumida ................................................ 244

\section{GRÁFICOS}

Gráfico 5-1: Tipo de predicado encaixador e tipos de complemento

Gráfico 5-2: Predicados encaixadores e complementos verbais (com base no corpus)

Gráfico 5-3: Predicados encaixadores e complementos nominais (com base no corpus) .

Gráfico 5-4: Predicados encaixadores de conhecimento e tipo de complementos .. 182

Gráfico 5-5: Predicados encaixadores de volição e tipo de complementos

Gráfico 5-6: Predicados encaixadores de manipulação e tipo de complementos .... 


\section{LISTA DE TABELAS}

Tabela 5-1: $\quad$ Tipos de completivas segundo o tipo de predicado encaixador .......... 159

Tabela 5-2: $\quad$ Camada de representação do complemento ........................................ 168

Tabela 5-3: $\quad$ Tipo de predicado encaixador e relações temporais ........................... 215

Tabela 5-4: $\quad$ Tipo de predicado encaixador e participantes ................................. 217

Tabela 5-5: $\quad$ Restrição a outros complementos ..................................................... 219 
1: primeira pessoa

2: segunda pessoa

3: terceira pessoa

A: actor

ACC: acusativo

AUX: auxiliar

COND: condicional

CONJ: conjunção

DEF: definido

DIR: direção

FAM: familiar

FUT: futuro

GDF: Gramática Discursivo-Funcional

GF: Gramática Funcional

IMPF: imperfectivo

INCH: incoativo

IND: completiva finita no indicativo

INDC: modo indicativo

INF IMPES: completiva não-finita com infinitivo impessoal como núcleo

INF PES: completiva não-finita com um infinitivo pessoal como núcleo

INV: inverso

LOG: logofórico

M: masculino

NOM: completiva não-finita com uma nominalização como núcleo 
NOMT: nominativo

OBV: obviativo

PFV: perfectivo

PL: plural

POL: polido

PROX: proximativo

PRS: tempo presente

PTCP: particípio

SG: singular

SUBJ: completiva finita no subjuntivo

TAM: tempo, aspecto e modo

TNS: tempo

$\mathrm{U}:$ undergoer 
SUMÁRIO

INTRODUÇÃO

PARTE I - PRESSUPOSTOS TEÓRICOS: A COMPLEMENTAÇÃO NA PERSPECTIVA DISCURSIVO-FUNCIONAL

CAPÍTULO 1 - A NOÇÃO DE COMPLEMENTAÇÃo EM DIFERENTES PERSPECTIVAS

1.1 Considerações iniciais

1.2 A completiva nos compêndios de gramática normativa e descritiva

1.3 O aparato formalista

1.4 O aparato funcionalista

1.5 A opção por uma perspectiva funcionalista para o tratamento da complementação

2.1 Considerações iniciais 54

2.2 O critério funcional-cognitivo para as relações de complementação 55

2.3 A semântica da complementação: as bases da ligação entre o predicado encaixador de complemento e o tipo de completiva

2.3.1 Integração semântica nas relações de complementação 60

2.3.2 Tipos semânticos de verbos e tipos de completivas: classificação das construções segundo a semântica do predicado encaixador

2.4 A gradação entre construções encaixadas verbais e nominais 
2.4.2 Os graus de sentencialidade e de nominalidade 92

2.5 Abordagem funcional para a complementação: enquadramento teórico 99

CAPÍTULO 3 - A GRAMÁTICA DISCURSIVO-FUNCIONAL

3.1 Considerações iniciais 102

3.2 O modelo da Gramática Discursivo-Funcional 103

3.3 As categorias semânticas na Gramática Discursivo-Funcional 113

3.4 O alinhamento na Gramática Discursivo-Funcional 121

\section{CAPÍTULO 4 - UNIVERSO DE PESQUISA E PROCEDIMENTOS} METODOLÓGICOS

4.1 Considerações iniciais

4.2 Considerações sobre metodologia de trabalho: corpus e frequência

4.3 Delimitação do corpus

4.4 Procedimentos metodológicos e técnicas de investigação

\section{CAPÍTULO 5 - DESCRIÇÃO FUNCIONAL DOS TIPOS DE CONSTRUÇÕES} ENCAIXADAS NOMINAIS E VERBAIS

5.1 Considerações iniciais

5.2 Descrição funcional dos tipos de completivas no corpus: aspectos gerais

5.3 Predicados encaixadores e tipos de completivas 
5.3.2 Predicados encaixadores de atitude proposicional

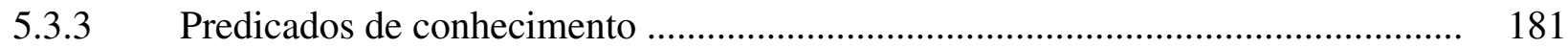

5.3.4 Predicados encaixadores de volição .................................................................. 186

5.3.5 Predicados encaixadores de manipulação ........................................................ 190

5.3.6 Predicados encaixadores de percepção física .................................................. 196

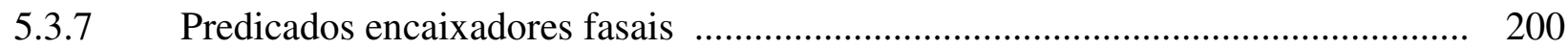

5.3.8 Predicados encaixadores de experiência psicológica ........................................ 206

5.3.9 Predicados encaixadores de tentativa ....................................................... 208

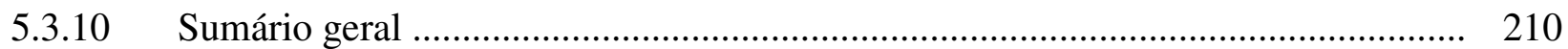

5.4 A determinação de participantes e referência TAM na seleção da completiva ...... 214

PARTE III - GENERALIZAÇÕES E IMPLICAÇÕES TEÓRICAS

CAPÍTULO 6 - MOTIVAÇÕES FUNCIONAIS DA GRADAÇÃO ENTRE CONSTRUÇÕES ENCAIXADAS NOMINAIS E VERBAIS

6.1 Considerações iniciais

6.2 Economia e iconicidade: integração semântica

6.3 Alinhamento representacional e integração semântica ...................................... 246

Considerações finais ........................................................................... 251 


\section{INTRODUÇÃO}

Esta pesquisa tem por objetivo investigar os tipos de orações completivas, distribuídas numa hierarquia entre mais ou menos verbal/nominal, tendo como suporte dados reais de conversação. ${ }^{1}$ Trata-se de um trabalho sobre a gramática da complementação do português brasileiro, mais especificamente sobre construções gramaticalmente disponíveis, com base em determinados tipos de predicados encaixadores verbais, em relação ao papel que essas construções exercem nas estruturas completivas do português. ${ }^{2}$

As línguas podem ter mais de uma expressão morfossintática disponível para a expressão de orações completivas e produzir uma variedade de tipos de construções encaixadas intra e interlinguisticamente (DIK, 1997b). No caso do português, num extremo da escala gradativa verbo/nome, é possível dispor de construções encaixadas verbais e, noutro extremo, de construções equivalentes a um membro prototípico dos nomes, uma nominalização; ${ }^{3}$ nesse continuum entre construções plenamente verbais e construções plenamente nominais, há também construções que oscilam entre as mais verbais e as mais nominais.

O estudo que proponho aqui tem como base a escala de variação entre construções encaixadas que figuram como complemento de orações hierarquicamente superiores, isto é,

\footnotetext{
${ }^{1}$ Neste trabalho, o termo completiva compreende as orações tradicionalmente denominadas orações substantivas objetivas diretas e indiretas, que, por definição, são introduzidas por predicado encaixador de natureza verbal. De acordo com Neves (2000), as orações substantivas são orações que equivalem a um sintagma nominal, isto é, têm as características de um elemento nominal. As orações que interessam para este trabalho são as que funcionam como argumento objeto da oração principal (cf. NEVES, 2000).

${ }^{2}$ Por complementação, entende-se o processo que se instaura entre um tipo de predicado encaixador e a oração dependente resultante.

${ }^{3}$ Ao tratar do caráter +/- prototípico da nominalização, Camacho (2009) considera que "o membro prototípico de uma categoria deve exibir todos os atributos que a representam e nenhum que represente outra categoria". Uma consequência disso é, segundo o autor, que um membro prototípico da classe dos nomes deve ser maximamente distinto de um membro prototípico da classe dos verbos. As nominalizações têm um caráter híbrido, a meio caminho entre a referência a uma entidade de primeira ordem, como os nomes comuns concretos, e a referência a um estado de coisas, como entidades de ordem superior. Na escala gradativa verbo/nome, quanto mais a construção encaixada se aproxima do polo do nome, mais o comportamento dela se aproxima ao de um membro prototípico da classe dos nomes.
} 
orações completivas finitas plenamente desenvolvidas e orações completivas não-finitas com um verbo infinitivo ou com uma nominalização como núcleo. Essa escala de variação fornece um conjunto de construções alternativas, cuja seleção pode depender de fatores funcionais, embora não seja uma possibilidade aberta a todos os tipos de predicados encaixadores. O predicado encaixador volitivo querer, por exemplo, pode ter como complemento construções mais verbais, como (1a), e construções mais nominais, como (1b-c); entretanto, para que uma oração não-finita com infinitivo como núcleo ocorra com um predicado como querer, por exemplo, como em (1b), é necessário que os participantes das orações matriz e subordinada sejam correferentes. Isso significa que as restrições possíveis ultrapassam a simples caracterização semântica do predicado encaixador.

(1)a. Alfredo queria que Alexandre brigasse com Ana.

b. Alfredo queria brigar com Ana.

c. Alfredo queria a briga de Alexandre com Ana.

O que procuro investigar neste trabalho é a variação entre construções completivas mais nominais e construções mais verbais e as consequências dela decorrentes. Meu interesse recai, dessa forma, nas possíveis motivações que governam, por um lado, as formas de construções completivas que se alternam na escala gradiente entre verbo/nome em português e, por outro, na seleção obrigatória de uma única construção encaixada. Espero que o tipo de exame aqui proposto permita realizar uma investigação criteriosa das motivações funcionais de natureza semântica e motivações estruturais que regem o funcionamento das construções encaixadas completivas.

O fenômeno da complementação sentencial é, de um modo geral, entendido como um mecanismo sintático em que uma oração é estruturada como argumento de um predicado. (cf. GIVÓN, 1980; NOONAN, 1985; LANGACKER, 1991; DIK, 1997b). De acordo com um critério funcional-cognitivo, desenvolvido por Cristofaro (2003), a partir de Langacker 
(1991), a subordinação completiva será tratada aqui como um modo de construir uma relação cognitiva entre dois estados de coisas. ${ }^{4}$ A um dos estados de coisas, o estado de coisas dependente, falta um perfil autônomo, sendo, por isso, construído a partir da perspectiva do outro estado de coisas, o estado de coisas principal. ${ }^{5}$

Os estudos sobre a subordinação completiva conferem atenção especial ao modo como as propriedades do predicado encaixador e da completiva interagem para determinar as possibilidades de um constituinte figurar como matriz ou como complemento de outro constituinte. Para Faber e Usón (1999), as diferentes concepções teóricas acerca do tema são determinadas pelo ponto de vista a respeito da relação que se estabelece entre o predicado encaixador e a oração completiva. Este trabalho, que adota uma perspectiva funcionalista para a análise de fenômenos linguísticos, traz uma concepção semântica das relações de complementação. A base teórica é a Gramática Discursivo-Funcional (HENGEVELD; MACKENZIE, 2008), muito embora outros suportes de orientação funcionalista, tais como Givón (1980, 1995), Noonan (1985), Lehmann (1988), Koptjevskaja-Tamm (1993), Cristofaro (2003), Malchukov (2004) e Dixon (2006), também sirvam como base para as hipóteses e interpretações aqui apresentadas.

Um dos postulados fundamentais da Teoria da Gramática Funcional (DIK, 1997a, 1997b) e, agora, da Gramática Discursivo-Funcional (GDF) é a necessidade de ajustar-se aos requisitos do princípio de adequação (i) tipológica, que está na formalização e na representação em camadas, (ii) psicológica, contido na própria formulação top-down do modelo recente, e (iii) pragmática, que parte de uma concepção do modelo no que diz respeito

\footnotetext{
${ }^{4}$ Estados de coisas são entidades de segunda ordem (cf. LYONS, 1977); ocorrem no mundo real ou podem ser criados no mundo mental do emissor e do destinatário; localizam-se no tempo e no espaço; podem ter certa duração; podem ser vistos, ouvidos ou percebidos de alguma forma (cf. DIK, 1997a; HENGEVELD; MACKENZIE, 2008).

${ }^{5}$ Cristofaro (2003) apresenta um estudo tipológico dos sistemas de subordinação, atribuindo os três tipos de relação de subordinação - completivas, adverbiais e relativas - aos mesmos princípios funcionais. Ao tratar das subordinadas completivas, a autora se restringe às tradicionalmente denominadas orações objetivas diretas. Mesmo se restringindo somente a essas completivas, o critério funcional-cognitivo de Cristofaro (2003) é suficiente para os propósitos deste trabalho.
} 
às propriedades da expressão linguística e os princípios e regras que governam a interação verbal. Assim, este trabalho encontra justificativa, por um lado, na necessidade empírica em si de descrever e explicar a língua falada a partir da definição de um fenômeno particular da estrutura do português, e, por outro, na necessidade teórica de testar os fundamentos metodológicos da GDF, na generalização dos fenômenos descritivos em direção a generalizações teoricamente produtivas sobre a complementação. A hipótese mais geral que dirige este trabalho é a de que quanto mais baixa a camada de representação do complemento tanto maior o grau de integração semântica entre o predicado da oração encaixadora e o predicado da oração completiva.

Um aspecto recorrente em alguns estudos que tratam do fenômeno da complementação diz respeito às propriedades semânticas do predicado encaixador em relação à oração completiva. Givón (1980), por exemplo, considera que a natureza semântica do predicado encaixador pode ser vista como um fator indicativo do grau de integração da oração subordinada à oração matriz. Hengeveld (1989, 1998) e Hengeveld e Mackenzie (2008) postulam que diferentes predicados encaixadores requerem diferentes tipos de complementos, cuja classificação depende da camada em que estejam contidos. Numa perspectiva tipológica, Cristofaro (2003) entende que as relações completivas são identificadas com base no predicado que codifica o estado de coisas principal e sua configuração semântica estabelece que tipo de especificação será requerido.

A semântica do predicado encaixador de completivas parece ser altamente relevante para predicações dependentes nucleadas em torno de uma construção nominal, de modo que a gradação entre construções nominais com verbo finito e construções nominais com grau máximo de nominalidade está correlacionada à categoria semântica do predicado encaixador. Embora não haja necessariamente uma relação biunívoca entre a semântica e tipo de construção, a categoria semântica do predicado encaixador é, ainda assim, um fator 
importante para a seleção da forma de expressão das orações subordinadas.

Outros fatores semânticos ligados aos princípios de economia e de iconicidade (GIVÓN, 1980; HAIMAN, 1983; CRISTOFARO, 2003), como o compartilhamento de participantes e referência a tempo, modo e aspecto, também podem influenciar o comportamento das orações completivas, determinando sua codificação morfossintática.

Além de considerar o significado do predicado encaixador para a seleção da completiva, pode-se também observar as orações completivas do ponto de vista do valor que elas expressam e analisá-las segundo o tipo de categoria para, assim, averiguar se o seu significado tem alguma influência sobre a forma que assumem. No âmbito da linguística funcional, em trabalhos como os de Dik (1997b), Dik e Hengeveld (1991) e Hengeveld (1990), essa proposição aparece desenvolvida, já que, nesses estudos, as orações completivas são tratadas como diferentes unidades semântico-funcionais. De qualquer modo, ainda que se analise o tipo de entidade representado pela completiva, isso pode ser feito somente a partir do significado do predicado encaixador.

Assumo aqui que as estruturas sintáticas são o reflexo formal da disposição de certos valores semânticos da construção complexa. De maneira ainda bastante simplificada, pode-se dizer que a oração completiva requerida depende da natureza semântica do predicado encaixador, bem como do tipo de entidade por ela representada - de primeira, de segunda, de terceira ou de quarta ordem -, que está diretamente relacionado à gradação mais ou menos verbal/nominal do complemento. ${ }^{6}$

Conforme já mencionado, no português, na escala gradativa dos tipos de complemento, é possível dispor, por um lado, de construções verbais completamente

\footnotetext{
${ }^{6}$ Lyons (1977) apresenta uma tipologia de entidades (três formas) que aprimora a tradicional distinção entre nomes concretos e abstratos. Nomes comuns, que têm um referente concreto, representam entidades de primeira ordem, enquanto os que se referem a estados de coisas e proposições representam entidades de segunda e de terceira ordem, respectivamente. A Gramática Funcional (DIK, 1997a) acrescenta a essa tipologia entidades de quarta ordem, que se localizam no tempo e no espaço e podem ser avaliadas em termos de suas condições de felicidade.
} 
desenvolvidas, e, por outro lado, de construções equivalentes a um membro prototípico dos nomes. Nessa escala entre construções plenamente verbais e construções plenamente nominais, podem ocorrer, ainda, outros tipos de construções intermediárias, como, por exemplo, as orações não-finitas com infinitivo. Diante disso, uma questão importante que se coloca é a do modo como se dá a seleção entre as diferentes expressões morfossintáticas quando o predicado encaixador fornece pelo menos duas alternativas possíveis. Outra questão igualmente relevante é saber em que condições a semântica do predicado encaixador impõe um padrão determinado para a expressão formal da complementação.

Se diferentes construções da escala gradual entre verbo e nome podem ocupar a posição de argumento na predicação de nível superior, é relevante verificar que motivações semânticas movem o indivíduo falante a fazer determinado tipo de predicação encaixada em detrimento de outro. Há, além disso, situações em que o estado de coisas da oração independente é dotado de suficiência formal e semântica para que a oração encaixada seja, por exemplo, obrigatoriamente uma nominalização ou obrigatoriamente uma oração finita. Nesse caso específico, é igualmente relevante verificar a natureza das motivações que regem esse tipo de construção complexa.

Em termos gerais, proponho uma investigação sobre a natureza e o funcionamento de construções encaixadas, mais especificamente, das construções encaixadas completivas, distribuídas numa hierarquia entre completamente verbais e completamente nominais, com o intuito de descobrir as motivações funcionais subjacentes à seleção dos diferentes tipos de construções como complemento de orações hierarquicamente superiores, tendo como objetivo final fornecer uma explicação funcional plausível para a sintaxe da complementação no português brasileiro falado.

A proposta de trabalho aqui definida procura responder às seguintes perguntas:

(i) Quais são os mecanismos formais para assinalar as relações entre os diferentes tipos de 
construções encaixadas - entendidas como orações finitas (indicativo e subjuntivo) e orações não-finitas (infinitivo pessoal, infinitivo impessoal e nominalização) - e os participantes do estado de coisas, por um lado, e a referência a tempo, modo e aspecto, por outro?

(ii) Qual é a similaridade e a dissimilaridade funcional entre os tipos formais de completivas do ponto de vista morfossintático, semântico e pragmático?

(iii) As restrições que houver à seleção de qualquer um dos tipos de mecanismo são sempre determinadas pelo predicado da oração matriz? Se não for, é determinação puramente formal? Dito de outro modo, qual seria a natureza dessa determinação, sintaticamente arbitrária ou funcionalmente motivada?

(iv) Não havendo nenhuma restrição do tipo mencionado em (iii), que fator funcional determina a seleção de um dos cinco procedimentos?

Essas perguntas de pesquisa, especificamente dirigidas ao subsistema de subordinação do português falado, conduzem a duas implicações teóricas de maior alcance:

(v) Qual é a classificação tipológica do português em relação aos diferentes tipos de construções encaixadas, com base nos procedimentos classificatórios de outros trabalhos (GIVÓN, 1980; CRISTOFARO, 2003)?

(vi) Os níveis de análise propostos pela GDF explicam adequadamente a restrição e a seleção de um dos procedimentos de encaixamento?

Para dar conta dessa proposta, conteúdo deste trabalho acha-se organizado em seis capítulos, que se somam a esta introdução, com uma distribuição formal em três grandes partes, que correspondem a uma investigação teórica, na Parte I, a uma investigação empírica, na Parte II, e às implicações teóricas resultantes, na Parte III.

A Parte I compõe-se dos Capítulos 1, 2, e 3, que tratam do quadro teórico geral que norteia as hipóteses e interpretação dadas ao fenômeno sob análise nesta pesquisa, constituindo, assim, o conjunto de princípios fundamentais. Nessa primeira parte, apresento a 
forma como a complementação é tratada em diferentes estudos, sobretudo o de orientação funcionalista. O Capítulo 1, especificamente, registra o tratamento que enfoques alternativos de gramática, como o formal, outras abordagens funcionais e o da gramática tradicional e descritiva, dispensam à relação de complementação. A discussão dos diferentes tratamentos fornece subsídios para a escolha do enfoque teórico que norteia a análise desenvolvida neste trabalho.

Definido o enfoque teórico, o Capítulo 2 apresenta a subordinação completiva a partir de perspectivas funcionalmente orientadas, considerando as relações que se estabelecem entre o predicado encaixador e a construção completiva; apresenta, adicionalmente, os tipos de classificação semântica disponíveis na literatura linguística, tendo como base Givón (1980), Noonan (1985), Cristofaro (2003) e Dixon (2006). Esse capítulo aborda, ainda, os tipos de completivas finitas e não-finitas e a gradação entre construções encaixadas nominais e verbais, com base no tratamento que Noonan (1985), Koptjevskaja-Tamm (1993), Mackenzie (1996), Dik (1997b) e Cristofaro (2003) dão ao tema.

Mesmo com um suporte teórico diversificado, este trabalho tem a GDF como o principal embasamento teórico, na medida em que é esse modelo que fornece os princípios explanatórios para fatos que, em outras perspectivas teóricas (não formalizadas), aparecem apenas como descritivamente adequados em função do baixo grau de formalização. Desse modo, o Capítulo 3 caracteriza, em linhas gerais, a GDF e trata das categorias semânticas que atuam nas diferentes camadas do Nível Representacional, bem como do tratamento dispensado pelo modelo à noção de alinhamento e à subordinação. Constitui um suporte teórico indispensável, já que, neste trabalho, faz-se uma associação entre os tipos de construções completivas e as camadas dos níveis de análise linguística em que se acham representados. 
A Parte II, formada pelos Capítulos 4 e 5, descreve os procedimentos metodológicos e destina-se à apresentação de evidência empírica para a hipótese da correlação entre predicados encaixadores e tipos de completivas e da relação entre tipos de completivas e a camada de representação, nos termos da GDF.

No Capítulo 4 está a descrição do aparato metodológico e do universo de pesquisa utilizados para o desenvolvimento da análise de dados. É nesse capítulo também que se encontram detalhadas as hipóteses de trabalho. O Capítulo 5 apresenta os dados coletados, paralelamente à sua descrição e interpretação. Procede à análise das orações completivas encontradas no corpus, categorizando-as com base na classificação dos predicados encaixadores propostos por Dixon (2006). Relaciona as interpretações, obtidas por meio da análise do objeto de estudo, aos postulados teóricos levantados nos capítulos anteriores e, principalmente, tenta comprovar ou rejeitar as hipóteses de trabalho.

A Parte III trata das generalizações e implicações teóricas. Fazendo um elo com a investigação empírica, apresentada no Capítulo 5, o Capítulo 6 fornece uma interpretação das construções completivas com base na organização em níveis e camadas e no princípio da integração semântica. 
PARTE I:

PRESSUPOSTOS TEÓRICOS - A

COMPLEMENTAÇÃO NA PERSPECTIVA

DISCURSIVO-FUNCIONAL 


\section{CAPÍTULO 1}

\section{A NOÇÃO DE COMPLEMENTAÇÃO EM DIFERENTES PERSPECTIVAS}

\subsection{Considerações iniciais}

Como especificado na seção introdutória, este trabalho alia-se a uma concepção semântica do fenômeno da complementação. Isso significa postular que são de ordem semântica as motivações que determinam a seleção de um tipo de complemento em relação ao predicado encaixador, o que, por princípio, já o caracteriza como um trabalho alinhado ao funcionalismo. Diante desse posicionamento, este capítulo aborda o tratamento dispensado à complementação por enfoques alternativos de gramática, para justificar a opção por um aparato funcional na investigação aqui proposta.

Assim, para demonstrar como a as construções completivas são tratadas em seus compêndios, a seção 1.2 tem como ponto de partida apresentar os conceitos prescritos na tradição gramatical - representada neste trabalho, sobretudo, pelos gramáticos Cunha e Cintra (2008), Bechara (2009) e Cegalla (2009) - e na gramática descritiva - com base, principalmente, em Mateus et al. (2003) e Neves (2002). A seção $\mathbf{1 . 3}$ enfoca a complementação sentencial a partir do aparato formal gerativista, com base nos trabalhos de Dillinger et al. (1996), que destacam fatores que condicionam a complementação verbal cujo complemento se realiza sob a forma de uma sentença, e de Mioto e Kato (2002), que apresentam uma análise formal das orações subordinadas, complementando o trabalho de Dillinger et al. (1996) - a relevância da escolha desses trabalhos está no caráter descritivo deles: diz respeito a um tratamento gerativo da complementação no Projeto da Gramática do Português Falado; a seção 1.4 mostra a complementação vista a partir de suportes teóricos de cunho funcionalista, representados pelos trabalhos desenvolvidos, especialmente, por Halliday 
e Hasan (1979), Givón (1980, 1993), Van Valin (1984), Lakoff (1984), Halliday (1985), Matthiessen e Thompson (1988), Lehmann (1988), Hopper e Traugott (1993), Dik (1997b) e Hengeveld e Mackenzie (2008). ${ }^{7}$ Essas três seções, além de tentarem construir um panorama geral da complementação vista sob enfoques diferentes, permitem, adicionalmente, observar como as noções de subordinação e encaixamento são tratadas no âmbito dos trabalhos orientados pelos enfoques tradicional e funcionalista. Para finalizar este capítulo, na seção 1.5, exponho as razões que justificam a opção pelo aparato funcional, em cotejo com a tradição gramatical e com o aparato formal.

\subsection{A completiva nos compêndios de gramática normativa e descritiva}

Na tradição gramatical, os estudos sobre subordinação apresentam, em sua maioria, tratamentos semelhantes, seguem uma tendência mais formal, isto é, em sua descrição, predominam critérios formais, baseados na dependência/independência sintática. A visão geral defendida pelos gramáticos, no que se refere à complementação, é a de que a oração subordinada funciona como termo de outra oração. De um modo geral, pode-se dizer que a gramática tradicional identifica as subordinadas com orações encaixadas que representam uma função sintática da oração considerada principal, por isso esse encaixamento é considerado obrigatório para as substantivas e adjetivas restritivas ou facultativo, na função de aposto, para as orações adjetivas não-restritivas ou adjunto nas relações adverbiais.

Nos termos de Cunha e Cintra (2008, p. 612), "as orações subordinadas funcionam sempre como termos essenciais, integrantes ou acessórios de outra oração". Para os autores, a subordinação é, na essência, equivalente a um período simples, distinguindo-se apenas pelo fato de ter o seu termo representado por uma oração. Seguindo esse raciocínio, Cunha e Cintra

\footnotetext{
${ }^{7}$ Cabe lembrar que o foco é o complemento sentencial que funciona como objeto de uma oração hierarquicamente superior. Embora seja importante avaliar em que medida os conceitos tratados nessas seções sobre subordinação abrangem os diferentes tipos de construções, o interesse deste trabalho recai somente nas completivas tradicionalmente tratadas como objeto direto e indireto, como salientado em nota anterior.
} 
(2008, p. 613) consideram que, no exemplo em (1-1a), o complemento de esperar é um substantivo; no entanto, em vez de uma construção nominal, seria possível a ocorrência de "um termo integrante representado por uma oração", como em (1-1b):

\section{(1-1)a. Ninguém esperava a tua vinda \\ b. Ninguém esperava que você viesse}

Com o verbo na forma finita, as orações subordinadas são encabeçadas pelo conector que, que marca a subordinação oracional. Além do tipo introduzido por que, os autores apresentam também um outro tipo de oração subordinada, a reduzida, que é a oração dependente cujo verbo se apresenta no infinitivo. Com isso, os autores distinguem, então, dois tipos de completivas, as finitas (indicativo e subjuntivo) e as com infinitivo.

Cegalla (2009) não foge à regra. A oração subordinada é vista como aquela que depende da oração matriz, servindo-lhe de termo, em termos de função sintática, e completando-lhe o sentido. Da mesma forma que Cunha e Cintra (2008), o autor considera dois tipos de completivas: a oração substantiva objetiva direta e indireta, quando desenvolvida, e a reduzida com infinitivo. Como as nominalizações aparecem, nas duas gramáticas, como exemplo de termos simples, elas não são consideradas um tipo de construção completiva oracional, a despeito de representarem, semanticamente, entidades de segunda ordem, já que o tratamento é formal.

Respeitando o 'peso da tradição', Bechara (2009) vê a completiva, primeiramente, como uma unidade de caráter oracional, uma oração complexa, para, posteriormente, analisar como oração subordinada o complexo unitário correspondente à função sintática exercida pelo substantivo. A marca de que uma oração passa por um processo de subordinação, funcionando como membro de outra oração, é a presença de que. Segundo o autor, a conjunção integrante não tem a função de juntar duas orações, mas de "marcar o processo por que se transpôs uma unidade de camada superior (uma oração independente) para funcionar numa camada inferior, 
como membro de outra oração" (BECHARA, 2009, p. 464). Daí preferir o termo orações complexas à denominação tradicional orações compostas ou período composto, isto é, orações que têm termos determinantes ou argumentais complexos, representáveis sob forma de outra oração, reservando o termo orações ou períodos compostos para a coordenação. $\mathrm{O}$ autor ressalta que as orações reduzidas são também subordinadas e quase sempre podem ser desdobradas em desenvolvidas, apresentando exemplos em que há equivalência semântica, como em 'declarei estar ocupado' e 'declarei que estava ocupado'.

Tanto Bechara (2009) quanto Vilela (1999) e Said Ali (2001) tratam da relação entre hipotaxe e subordinação. Segundo Bechara (2009), a hipotaxe consiste na possibilidade de uma unidade correspondente a um estrato superior poder funcionar num estrato inferior: uma oração passar a funcionar como membro de outra oração e isso é o que se chama subordinação. Para subordinar uma oração, é necessário, primeiramente, marcar a relação, isto é, indicar que uma estrutura oracional de verbo flexionado funciona como membro de uma oração (e não como oração independente) e, posteriormente, indicar a função que essa estrutura exerce na oração complexa. No português, a marca de subordinação é que.

Tal como Bechara (2009), Azeredo (2000) também denomina de transpositor a marca de subordinação, cujas características básicas são o fato de pertencerem às unidades que introduzem e servirem de marca formal da classe dessas unidades. A transposição é, desse modo, um processo gramatical "pelo qual se formam sintagmas derivados de outras unidades, as quais podem ser sintagmas básicos ou orações", permitindo "expandir infinitamente os enunciados, mediante a utilização de um número limitado de meios - os transpositores - e de um número limitado de relações semânticas fundamentais" (AZEREDO, 2000, p. 211). No que tange às conjunções integrantes que transpõem a oração à condição de substantivo, o autor as denomina nominalizadores. 
Ainda sobre o subordinador que, Perini (1995) defende a idéia de que ele não faz parte da oração subordinada. Esse elemento não teria função conhecida dentro da oração, além do fato de que uma seqüência introduzida por que não poderia ocorrer sozinha. Argumenta que, nos casos de oração desenvolvida, constrói-se o complemento verbal por meio de um sintagma nominal composto por que + oração.

Vilela (1999, p. 383) denomina as subordinadas substantivas de frases de complemento: são frases dependentes que "ocupam os lugares vazios dos portadores de valência". Segundo o autor, "o predicado da frase subordinante tem a capacidade de designar os traços, as propriedades de estados de coisas das frases subordinadas delas dependentes" (VILELA, 1999, p. 383).

Mateus et al. (1983) caracterizam as orações completivas como estruturas de encaixe, classificando as orações de acordo com a forma verbal. Em Mateus et al. (2003), as autoras estabelecem algumas distinções e propriedades das completivas finitas, que ocorrem com verbos desenvolvidos no indicativo ou conjuntivo, e não-finitas, que ocorrem no infinitivo flexionado ou não-flexionado.

Mateus et al. (2003) consideram que as completivas finitas são unidades (ou termos) constituintes da oração matriz (frase superior) e confirmam isso por meio de testes de constituência, como a substituição (i) por pronome demonstrativo (pronominalização), como em (1-2a-b), e (ii) por um item de polaridade afirmativa ou negativa, como em (1-3a-b) método que distingue o complementador introdutor (que constitui o núcleo sintático da completiva finita) e a completiva.

(1-2)a. Os críticos disseram [que esse filme ganhou o festival].

b. Os críticos disseram [isso].

(1-3)a. Os críticos disseram que [esse filme ganhou o festival].

b. Os críticos disseram que [sim/não]. 
As autoras estabelecem também relação entre as propriedades semânticas dos verbos da matriz e a seleção do modo da completiva. Buscando a configuração dos contextos em que ocorre o modo indicativo ou o modo subjuntivo, apresentam as seguintes características:

\begin{tabular}{|c|c|}
\hline Indicativo & Subjuntivo \\
\hline Indicam conhecimento, crença & Verbos factivos \\
Predicados assertivos & Predicados pseudo-assertivos \\
{$[+$ epistêmico] } & {$[$ - epistêmico] } \\
Completiva [- dependente] & Completiva [+ dependente] \\
Maior valor de verdade & Menor valor de verdade \\
\hline
\end{tabular}

Quadro 1-1: Caracterização do modo verbal da completiva (cf. Mateus et al., 2003, p. 609)

Os verbos epistêmicos, como acreditar, crer, duvidar, pensar, e avaliativos como gostar, estão entre os verbos que selecionam completivas com relação de objeto direto. São verbos que selecionam completivas tanto no modo indicativo quanto no subjuntivo (cf. MATEUS et al., 2003). No modo indicativo, o sujeito da completiva que aparece lexicalmente realizado é interpretado como não-correferencial ao sujeito da matriz, no português europeu.

(1-4) João $\mathrm{o}_{\mathrm{i}}$ acredita que ele $\mathrm{j}_{\mathrm{j}}$ está à espera de Maria.

Ao contrário, se o sujeito da completiva não aparece lexicalmente realizado, mas tem traços de pessoa e número compatíveis com o sujeito da matriz, é entendido preferencialmente como correferencial:

(1-5) João $\mathrm{J}_{\mathrm{i}}$ acredita que [i] está à espera de Maria.

Com base nessas interpretações, Mateus et al. (2003) propõem que, nas línguas que admitem sujeito nulo nas completivas não-finitas, evite-se o pronome sujeito nas completivas finitas quando se pretende correferencialidade entre os sujeitos. Na realidade, o tratamento semântico de Mateus et al. (2003) tem o objetivo claro de fornecer uma especificação para a 
expressão formal das completivas, seja em termos do modo, seja em termos de expressão de argumentos.

As autoras relacionam os predicadores que selecionam completivas oblíquas finitas à subclasse dos verbos de controle de objeto, ou seja, àqueles que selecionam um sintagma nominal objeto direto que funciona como sujeito da completiva finita (como, por exemplo, os predicados aconselhar, convencer, convidar e forçar). Esse tipo de completiva pode ser introduzido pelas preposições a (habituar-se), de (aperceber-se, arrepender-se, convencer-se, envergonhar-se, esquecer-se, lembrar-se, recordar-se), em (concordar, insistir) e por (esforçar-se e interessar-se).

Quanto aos predicadores que selecionam completivas oblíquas não-finitas, Mateus et al. (2003) postulam que as preposições não funcionam como os complementadores (introduzindo a completiva), já que, nas completivas finitas correspondentes, precedem obrigatoriamente o complementador que. Essas construções são denominadas infinitivas canônicas, por não poderem ser substituídas por orações com gerúndio, construindo-se tanto com o verbo no infinitivo não-flexionado quanto flexionado.

Neves (2002) considera que as orações substantivas constroem-se com verbos no infinitivo ou finitos. Essas construções podem vir introduzidas por uma conjunção integrante - casos em que o verbo apresenta-se em uma forma finita no indicativo ou subjuntivo - e funcionam como complemento de um termo de outra oração, o predicado matriz. As orações completivas têm, assim, o papel de argumento em relação a um termo valencial da oração principal. De acordo com Neves (2002), como argumento do verbo, as orações completivas podem exercer todas as funções argumentais ligadas a verbo exercidas por um sintagma nominal (sujeito, objeto direto e indireto).

As orações completivas verbais (objetivas diretas e indiretas) são tratadas por Neves (2002) em relação aos tipos de predicados matrizes. A autora apresenta as possibilidades de 
ocorrência de construções finitas ou não-finitas tendo em vista a correferencialidade (ou a falta de correferencialidade) dos sujeitos da oração matriz e da completiva. Verbos de elocução (como dizer, perguntar etc.), de atividade mental (como achar, acreditar, imaginar etc.), avaliativos factivos (como adorar, gostar, lamentar etc.), volitivos (como desejar, preferir, esperar etc.), factitivos (como mandar, deixar, fazer etc.) e de percepção (como ver, ouvir e sentir) introduzem orações completivas diretas. ${ }^{8}$

As orações completivas indiretas podem ser introduzidas pelas preposições alde/com/em/para + que com verbo na forma finita, sendo o sujeito da matriz e da completiva não-correferencial; quando introduzida pelas preposições aldelcom/em/para como verbo no infinitivo, o sujeito da completiva é entendido, em princípio, como correferencial ao sujeito da oração matriz (cf. NEVES, 2002). As completivas indiretas aparecem exemplificadas pela autora com verbos reflexivos como lembrar-se, esquecer-se, recordar-se, conscientizar-se etc., e com verbos não-reflexivos, como obrigar, duvidar, insistir etc.

Feitas essas considerações sobre o modo como a tradição normativa gramatical e a descritiva tratam a complementação, a seção seguinte ocupa-se especificamente da abordagem gerativista para a complementação, restrita à Teoria da Regência e da Ligação (CHOMSKY, 1981).

\subsection{O aparato formalista}

A abordagem gerativista parte do pressuposto de que uma teoria da complementação tem por objetivo elucidar a estrutura interna do predicado, atribuindo ao núcleo do predicado características específicas para explicar a ocorrência ou não de complementos. A

\footnotetext{
${ }^{8}$ Neves (2002, p. 348) faz menção às construções nominalizadas ao considerar que alguns verbos, como os de atividade mental, assumem complementos não-oracionais, e, quando isso ocorre, "o sintagma nominal que o compõe é representado por uma nominalização".
} 
subcategorização do verbo determina a categoria do complemento e as restrições de seleção explicitam as características semânticas do complemento.

A premissa central da abordagem gerativista é a de que a estrutura sintática da frase é projetada a partir das informações lexicais de seus elementos. As regras de estrutura frasal constituem restrições sobre a combinação de informações lexicais invioláveis. Na relação entre léxico e sintaxe, é o léxico que determina a sintaxe. Um problema com essa abordagem é, segundo Dillinger et al. (1996), a redundância de representação:

A informação concernente à classe de esquemas de subcategorização é, de fato, dada duas vezes na gramática: uma - implicitamente - no léxico, como uma propriedade da classe de itens lexicais em sua totalidade; e outra - dessa vez diretamente - pelas regras do componente categorial. (CHOMSKY, 1981, p. 31). ${ }^{9}$

A teoria X-barra procurou reformular as regras de estrutura frasal sem se referir às categorias específicas, de modo a eliminar a redundância de representação:

A informação sobre a classe de esquemas de subcategorização, que é dualmente representada, não pode ser eliminada da entrada lexical. Portanto, deveríamos tentar eliminá-la do componente categorial. O princípio de projeção, de fato, realiza isso, de um modo suficientemente amplo. Dado o princípio de projeção e as propriedades gerais da teoria X-barra, o componente categorial para uma gramática particular será muito restrito. (CHOMSKY, 1981, p. 32). ${ }^{10}$

A teoria X-barra reduz a estrutura frasal à relação de predicação, que se dá entre o sujeito e o núcleo do predicado, e à relação de complementação, que ocorre entre o núcleo do predicado e seus complementos. Outra consequência é, segundo Stowell (1982), a virtual eliminação de especificação categorial da teoria da estrutura frasal, o que proporciona uma

\footnotetext{
${ }^{9}$ Cf. original: information concerning the class of subcategorization frames is in effect given twice in the grammar: once - implicitly - in the lexicon, as a property of the class of lexical items in its totality; and once this time directly - by the rules of the categorial component.

${ }^{10}$ Cf. original: The information about the class of subcategorization frames that is thus dually represented cannot be eliminated from lexical entries. Therefore, we should attempt to eliminate it from the categorial component. The projection principle in fact accomplishes this, in a quite sweeping way. Given the projection principle and the general properties of X-bar theory, the categorial component for a particular grammar will be quite meager.
} 
harmonia categorial, já que tanto o verbo quanto as outras categorias maiores teriam sujeito e complementos.

De acordo com Dillinger et al. (1996), a complementação é determinada principalmente por informações lexicais idiossincráticas sujeitas às restrições sistemáticas da teoria X-barra. A inviolabilidade das informações lexicais é garantida pelo Princípio de Projeção e pelo Critério Theta.

O critério temático estipula quantos argumentos o item permite e que tipo de relação se dá entre esse item e o outro realizado como seu argumento. Ao propor essa abordagem, Chomsky (1986) postula uma relação sistemática entre categorias semânticas e categorias sintáticas. Segundo o autor, "se um verbo (ou outro núcleo) s-seleciona uma categoria semântica C, então ele c-seleciona uma categoria sintática que é a "realização estrutural canônica" de C" (CHOMSKY, 1986, p. 86). ${ }^{11}$ As informações categoriais são eliminadas do componente de estrutura frasal pela adoção da teoria X-barra e são eliminadas do léxico, sendo possível derivá-las das restrições de s-seleção e da especificação das realizações estruturais canônicas. Somente são representadas lexicalmente eventuais características idiossincráticas de c-seleção.

Ouhalla (1991) propõe a eliminação da c-seleção dos elementos lexicais das classes maiores, para os quais somente seriam estipuladas as características de s-seleção, e restringe a especificação de c-seleção às categorias funcionais. O critério temático de Chomsky (1981) estipula que as informações temáticas especificadas lexicalmente têm que receber uma manifestação na estrutura frasal que seja não-ambígua, isto é, para cada papel temático corresponderá somente um constituinte da frase. Nesse quadro, a complementação não é necessariamente determinada pelas características do verbo: a c-seleção é derivada da sseleção, portanto, não é diretamente importante na estrutura frasal. A s-seleção, por sua vez,

\footnotetext{
${ }^{11}$ Cf. original: (...) if a verb (or other head) s-selects a semantic category $\mathrm{C}$, then it c-selects a syntactic category that is the "canonical structural realization" of $\mathrm{C}$.
} 
por se tratar de propriedades semânticas, é uma característica da interpretação semântica e não necessariamente da construção da estrutura frasal a ser interpretada.

Para Dillinger et al. (1996), o que resta como determinante importante da complementação é, na verdade, a teoria X-barra, ou seja, os princípios de estrutura sintática que são independentes das informações lexicais e semânticas. Segundo os autores, partir do pressuposto de que é principalmente a teoria X-barra que determina a natureza da complementação permite chegar à hipótese da existência de uma estrutura sintática padrão, definida pela formulação dessa teoria, que prevê para a frase um sujeito, um verbo, um complemento e um número indeterminado de adjuntos (JACKENDOFF, 1977).

No que tange especificamente à complementação oracional, em seu trabalho, Dillinger et al. (1996) consideram certos fatores que condicionam a complementação verbal que apresenta um dos argumentos realizado sob a forma de uma sentença.

Um primeiro fator analisado pelos autores diz respeito ao tipo de verbo matriz. As sentenças completivas são classificadas segundo sua finitude; assim, os autores tratam das orações finitas com indicativo e com subjuntivo, as infinitivas e as miniorações (small clauses) e as relacionam com o tipo de verbo matriz, em termos da exigência de complementos; como se vê, essa relação é formal, não semântica, pois parte da ideia de que o predicado abre lacunas a serem preenchidas por argumentos - termos simples ou complexos.

$\mathrm{Na}$ análise dos dados, os autores observam que, com verbos de um complemento, o indicativo é o segundo mais usado, perdendo em frequência apenas para o infinitivo. Em relação aos verbos de dois complementos, há uma tendência para que o complemento seja uma oração finita com indicativo. As miniorações aparecem somente com verbos de um complemento. Esses complementos estão associados a um tipo de verbo que seleciona um tipo de complemento característico, que é incompatível com outro complemento. O complemento infinitivo é, segundo os autores, o mais privilegiado, por perfazer o maior 
número de ocorrências em relação aos outros tipos de complementos. Os números confirmam, assim, a facilidade com que esse tipo de complemento tende a ser escolhido. O subjuntivo é o tipo menos favorecido, com apenas uma ocorrência para cada tipo de verbo analisado (de um ou de dois complementos).

Outro fator analisado diz respeito à ordem dos constituintes no complemento sentencial, mais especificamente a posição do sujeito e do verbo, e do verbo e do objeto. Os autores salientam que a posição tanto do sujeito quanto a do objeto segue o arranjo distribucional canônico, com sujeito anteposto e objeto posposto ao verbo.

Além do tipo de verbo e da ordem dos constituintes no complemento sentencial, os autores observam também a relação entre a natureza semântica do verbo matriz e o tipo de complemento, sentença no indicativo e no infinitivo - um fator, então, menos formal em relação aos outros. Para os autores, os resultados obtidos deixam claro que a natureza semântica do verbo desempenha um papel no tipo de complemento que ele seleciona, se não por restringir-se a um único complemento, pelo menos por estabelecer condições restritivas quanto ao tipo de complemento que pode ser selecionado.

Mioto e Kato (2002) apresentam uma análise formal das orações subordinadas, complementando o estudo empírico de Dillinger et al. (1996), sobre as completivas de verbos, assim como o de Neves (1996), sobre as completivas de nomes. Nesse trabalho, os autores acrescentam as construções completivas de adjetivo, além de representarem alguns tipos de orações adverbiais.

Mioto e Kato (2002) argumentam que, no tratamento da subordinação sentencial, devem-se considerar dois aspectos: um aspecto interno, voltado para a estrutura da própria sentença (finita ou não-finita), e um aspecto externo, em que se encontram os constituintes responsáveis pelo licenciamento e pela forma da sentença subordinada. Em termos de estrutura e função, uma sentença encaixada é uma categoria funcional $\mathrm{CP}(\mathrm{C}=$ 
complementizador), que responde pela interface entre o conteúdo proposicional e a estrutura externa. De acordo com Rizzi (1997 apud MIOTO; KATO, 2002), o sistema C deve expressar dois tipos de informação, um voltado para o exterior e o outro voltado para o interior.

O aparato formalista tem uma concepção puramente sintática das relações de complementação. A relação entre oração matriz e subordinada é tratada em termos de configurações sintáticas que são estabelecidas para os constituintes de uma língua de acordo com a estrutura formal de seus complementos. No trabalho de Dillinger et al. (1996), é possível observar especificamente motivações semânticas nas relações de complementação; mesmo assim, elas parecem ser determinadas, em primeiro lugar, por traços sintáticos, cabendo à informação semântica dos constituintes apenas um papel adicional e secundário.

Dando continuidade ao conteúdo proposto para este capítulo, a próxima seção apresenta o último tipo de enfoque observado para as relações de complementação, isto é, o da perspectiva funcional.

\section{$1.4 \mathrm{O}$ aparato funcionalista}

Halliday e Hasan (1979) compreendem a frase complexa a partir dos mecanismos de coesão textual. Para os autores, conjunção é um tipo de relação coesiva que especifica o modo como aquilo que vem depois é sistematicamente conectado com o que vem antes; frase complexa, por sua vez, é a unidade gramatical acima da oração, equivalente à sentença. A oração hipotática é definida como uma oração dependente da outra, mas que não está estruturalmente integrada a ela como um constituinte. Enquanto a oração encaixada perde sua identidade funcional como oração, a oração hipotática, ao contrário, não a perde, mantendo-se como elemento da estrutura da oração complexa e, por isso, serve prontamente de alvo da pressuposição a partir da outra oração complexa (HALLIDAY; HASAN, 1979). Essa é a base 
da distinção entre hipotaxe e encaixamento, que, segundo os autores, não fica clara com o uso do termo embedding.

Halliday (1985) estabelece a distinção entre encaixamento, de um lado, e relações táticas de parataxe e de hipotaxe, de outro. A parataxe e hipotaxe codificam relações entre orações; o encaixamento, por sua vez, é um sistema lógico-semântico e constitui um mecanismo pelo qual uma oração desempenha uma função na estrutura de uma outra oração. Há, segundo o autor, duas dimensões na interpretação da frase complexa, uma formal e a outra lógico-semântica:

(i) o sistema de interdependência, ou sistema tático, que é formado pela parataxe, que constitui a relação entre dois elementos de igual estatuto (um iniciando e o outro continuando), e pela hipotaxe, que constitui a relação entre elementos de diferentes estatutos, isto é, entre um elemento dependente e seu dominante;

(ii) o sistema lógico-semântico de expansão e projeção refere-se a uma relação interoracional, ou melhor, relação entre processos, geralmente expresso na gramática como um complexo de orações.

As relações entre orações, interpretadas em termos do componente lógico do sistema linguístico, são identificadas como relações semântico-funcionais que fazem a lógica da linguagem natural (cf. HALLIDAY, 1985).

Van Valin (1984) mantém a distinção de Halliday e Hasan (1979), postulando o envolvimento de dois componentes na oposição coordenação x subordinação: a dependência na forma $[+/$ - dependente] e o encaixamento de uma estrutura na outra $[+/$ - encaixado]. $\mathrm{O}$ autor estabelece três relações de ligação, conforme o grau de tensão sintática que resulta da combinação das orações: (i) coordenação: [- dependente, - encaixado]; (ii) subordinação: [+ dependente, - encaixado], que corresponderia às orações hipotáticas de Halliday e Hasan 
(1979); (iii) co-subordinação: [+ dependente, + encaixado], que corresponderia às orações encaixadas de Halliday e Hasan (1979).

R. Lakoff (1984) atribui a dificuldade de se trabalhar com coordenação e subordinação ao enfoque dicotômico, em que ser uma coisa não implica não ser outra. Expandindo esse ponto de vista simplificador, a autora propõe uma classificação gradual das orações, o que permitiria ser uma oração mais ou menos coordenada ou mais ou menos subordinada, conforme as características que apresente. Desse modo, distribui as orações tradicionalmente coordenadas e subordinadas em um continuum que envolve quatro níveis: no primeiro nível está a parataxe pura, em que as orações são justapostas sem conector explícito; no segundo nível está a mixotaxe, em que as orações são coordenadas com a presença de conjunção coordenativa, que explicita a existência de relação entre as orações; no terceiro nível, o da quase-hipotaxe, há subordinação de uma idéia ou de uma oração a outra, sendo as duas orações sintaticamente autônomas e estando o conector explícito; no quarto nível, o da hipotaxe pura, as orações estão subordinadas tanto sintático quanto semanticamente devido à perda da identidade sentencial plena de uma das orações. Nessa proposta de Lakoff (1984), a hipotaxe pura corresponde ao encaixamento e a quase-hipotaxe, à hipotaxe, na terminologia de Halliday e Hasan (1979).

Matthiessen e Thompson (1988) fornecem um tratamento discursivo para a hipotaxe. Por acreditarem não ser suficiente apenas conhecer o grau de independência das orações, os autores procuram detectar que função discursiva motiva a gramática da hipotaxe. A hipótese levantada é a de que a gramática da combinação de orações reflete a organização do discurso, ou seja, a hipotaxe é uma gramaticalização da estrutura organizacional do texto. Deixa-se de lado, desse modo, a gramática da combinação da oração para explorar a organização retórica do discurso. A descrição dessa estrutura é dada pelas relações retóricas entre as partes de um texto (relações de motivação de concessão, de circunstanciação, de condição etc.), que são de 
dois tipos: relação núcleo-satélite, em que um membro do par relacionado é subordinado ao outro, e relação de listagem, em que nenhum membro do par é subordinado.

Há uma analogia explícita entre a organização retórica do discurso e a organização gramatical das orações: ambas têm uma estrutura cujos elementos são interdependentes, correspondendo a distinção entre relações retóricas de listagem e de núcleo-satélite à distinção gramatical entre parataxe e hipotaxe (cf. MATTHIESSEN; THOMPSON, 1988). Desse modo, a oração encaixada é um argumento que compõe uma predicação, enquanto as orações hipotáticas têm função de satélite e formam orações combinadas.

Lehmann (1988) postula uma classificação gradual da articulação de orações, que, abrangendo dois extremos prototípicos em cada um dos pólos do continuum, vai da parataxe ao encaixamento. A parataxe é entendida como a coordenação de orações; a hipotaxe e o encaixamento são vistos como dois tipos particulares de subordinação: a hipotaxe é a subordinação no sentido estrito e o encaixamento é a dependência de um sintagma subordinado.

O autor se detém no processo de integração da construção subordinada à principal, tratando da dessentencialização, ou seja, de um processo de rebaixamento hierárquico em que uma oração perde suas características para tornar-se um constituinte da oração principal. Num extremo do continuum, em que figura a sentencialidade em grau máximo, não há uma relação hierárquica entre duas orações que formam a sentença complexa (processo chamado de parataxe); noutro extremo, em que figura a sentencialidade em grau mínimo, está a típica oração encaixada, governada por um verbo principal (subordinação).

sentencialidade

oração

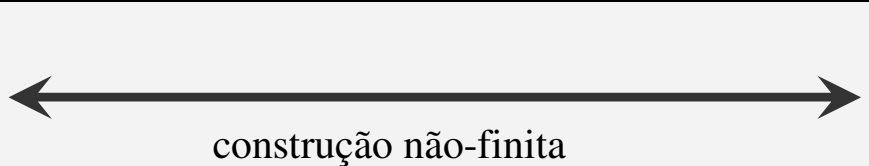

construção não-finita nominalidade

nome verbal

Figura 1-1: Dessentencialização (adaptada de LEHMANN, 1988, p. 200) 
Orações subordinadas, normalmente, não têm sua própria força ilocucionária, mas os casos que têm, restritos, em geral, aos predicados performativos, vão-se tornando raros, segundo Lehmann (1988), na medida em que se aproximam do pólo direito do continuum. Uma outra conseqüência da dessentencialização é a restrição de modo, além das categorias verbais de tempo e aspecto. Como, segundo o autor, em várias línguas, a oração subordinada finita aparece no subjuntivo, a restrição de modo está intimamente ligada à perda de força ilocucionária: na medida em que uma construção finita, gradualmente, passa a não-finita, limita-se o modo.

Lehmann (1988), respaldando-se em Dik (1985) e Mackenzie (1985), assinala que o processo de dessentencialização afeta a relação do predicado verbal com seus argumentos. $\mathrm{O}$ sujeito de uma predicação subordinada relativamente 'enfraquecida' converte-se em um oblíquo, ou simplesmente se perde a posição estrutural de sujeito. Esse argumento interno é, assim, o primeiro a ser afetado pela dessentencialização. Numa nominalização, os sintagmas nominais correspondentes aos argumentos do verbo finito aparecem no genitivo ou em sintagmas adposicionais. ${ }^{12}$ Um verbo não completamente nominalizado pode ter um objeto direto e um advérbio; já um verbo mais nominalizado é modificado por um adjetivo, como um nome. Quanto mais a construção subordinada se aproxima do polo direito do continuum, mais o comportamento dela se aproxima ao de um membro prototípico dos nomes. Nesse sentido, pode-se falar de um grau crescente de nominalidade, quando a oração subordinada é hierarquicamente rebaixada pelo processo de dessentencialização.

Segundo Neves (1999), tanto na linha da dependência (independência interdependência - dependência) quanto na linha da integração gramatical (coordenação - cosubordinação - subordinação), supõe-se um continuum, que permite investigações como a que está em Lehmann (1988):

\footnotetext{
${ }^{12}$ Lehmann (1988) baseia-se no inglês, cuja gramática codifica um dos argumentos como a forma genitivo ('s) e a outra mediante adposição; já a gramática do português usa sempre a adposição para codificar dois argumentos igualmente presentes: a preocupação de Maria com a eleição.
} 
(i) a expressão morfossintática de cada oração, como resultado dos graus de redução do caráter sentencial:

- oração desenvolvida (conjuncional com verbo finito) >

- orações reduzidas (com verbo não-finito - redução da finitude) >

- nominalização (dessentencialização)

(ii) o partilhamento de categorias, como evidência de entrelaçamento, ou co-participação:

- partilhamento de sujeito, de tempos ou modos verbais >

- redução a uma única estrutura de superfície

Hopper e Traugott (1993) salientam, por seu lado, que não existem expressões isoladas, visto que as expressões estão atreladas a um contexto discursivo específico, na medida em que são unidades que se desenvolvem no âmbito de uma atividade linguística. Os autores argumentam que, como todas as línguas têm mecanismos de ligação oracional, que chamam de orações complexas, é possível postular uma tripartição das orações complexas, apresentando uma caracterização de parataxe, hipotaxe e subordinação com base nos critérios de dependência, integração e tipo de ligação entre as orações (cf. HOPPER; TRAUGOTT, 1993, p. 171):

Parataxe Hipotaxe Subordinação

(independência) (interdependência) (dependência) núcleo margem integração mínima integração máxima ligação explícita máxima ligação explícita mínima

Essa tripartição apresenta a seguinte conjunção de propriedades: 


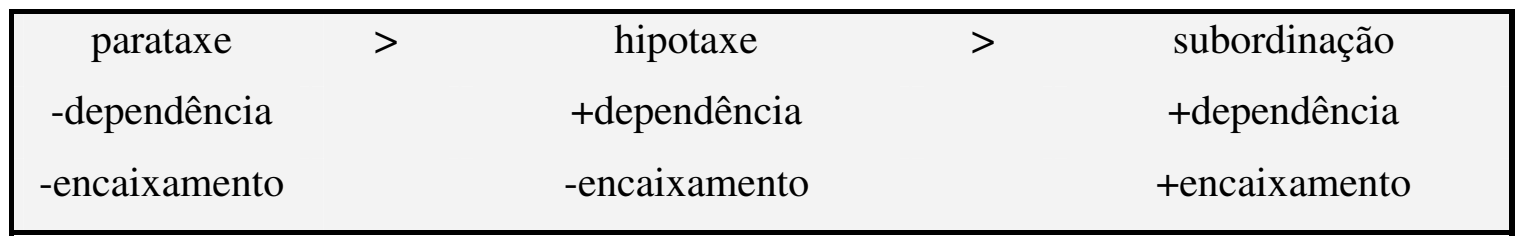

Quadro 1-2: Tripartição de orações complexas (cf. HOPPER; TRAUGOTT, 1993, p. 170)

De um modo geral, pode-se dizer que perspectivas como as de Hopper e Traugott (1993), Lehmann (1988) e Halliday (1985) têm a vantagem de romper com a visão tradicional de que a oração coordenada é independente sintática e semanticamente da cláusula a que se encontra adjacente, ao passo que as subordinadas são dependentes - sintática e semanticamente - da principal. Todos esses autores propõem uma classificação escalar que permite constatar que as orações têm um maior ou menor grau de coordenação, de subordinação ou de encaixamento. Não há, assim, uma classificação estrita para a subordinação, assim como não há para a coordenação ou para a hipotaxe. Há limites difusos entre essas categorias, com construções se aproximando ou se distanciando dos membros mais representativos de um protótipo.

Ainda no âmbito da perspectiva funcional, a complementação é tratada por Givón (1980, 1993) em termos de integração semântica. ${ }^{13}$ O autor considera que a natureza semântica do predicado complementado pela oração pode ser vista como um fator indicativo do grau de integração da oração subordinada à oração matriz. Givón (1980) estabelece, desse modo, uma relação relevante entre a estrutura semântica do predicado encaixador e a estrutura sintática de seus complementos, que pode variar de construções verbais plenamente desenvolvidas a construções nominalizadas.

Na linguística funcional de linha holandesa, Dik (1997b) distingue as orações com função argumental das orações com função de satélite, estabelecendo um paralelo entre as construções simples e complexas. Na versão standard da Gramática Funcional (GF), as

\footnotetext{
${ }^{13}$ Esse assunto será tratado com mais detalhes no próximo capítulo.
} 
posições de argumentos e de satélites podem ser preenchidas por termos na representação subjacente. Termos permitem, ao destinatário, construir a representação mental de uma entidade qualquer, ou identificar/retomar uma entidade já estabelecida em seu mundo mental (DIK, 1997b).

O tipo primário de termo é representado em geral por um nominal que se refere a alguma entidade de primeira ordem, e o modelo de expressão prototípico para esse termo inclui constituintes como determinante, quantificador, possuidor, adjetivo, nome. Em referência a entidades de ordem superior, os termos podem ser representados por nomes simples ou por termos complexos operando como restritores, que constituem construções contendo uma predicação ou uma proposição.

Ao postular a distinção entre argumentos e satélites, Dik (1997b) distingue termos exigidos pela semântica do predicado (argumentos) e termos que fornecem informações adicionais (satélites). Argumentos e satélites são inseridos em diferentes níveis das camadas da estrutura subjacente da oração.

Cabe salientar que a noção de encaixamento de Dik (1997b) difere das noções apresentadas até aqui. Para a $\mathrm{G}(\mathrm{D}) \mathrm{F}$, encaixamento diz respeito à inserção de orações na posição de argumentos ou de satélites. Uma oração pode ocorrer como constituinte de outra oração, encaixando-se na posição de predicado (oração predicativa), de argumento (oração completiva) ou de modificador (oração adverbial e relativa).

O encaixamento de orações que ocupam a posição de segundo argumento de uma oração depende da natureza semântica do predicado encaixador, que acaba por determinar o nível a que cada termo se refere. O tratamento da subordinação a partir das camadas de representação também é sustentado por Dik e Hengeveld (1991), Hengeveld (1990a, 1990b), e Bolkestein (1990, 1992). Na versão mais recente da GF, a GDF (HENGEVELD; 
MACKENZIE, 2008), essa posição se mantém, isto é, as orações subordinadas são classificadas de acordo com a camada mais alta que as contém.

Na GDF, a expressão linguística, a maior unidade de análise, é vista como um conjunto de orações e cada oração, por sua vez, consiste em uma (ou mais) palavra(s), ou em um (ou mais) sintagma(s), ou, ainda, como exemplo de recursividade, em uma (ou mais) oração(ões).

Para a GDF, um aspecto relevante do processo de subordinação é a atuação dos fatores interpessoal, representacional e morfossintático responsáveis pela escolha de um determinado tipo de oração subordinada. É igualmente relevante a dependência da oração subordinada à oração matriz no que diz respeito à expressão de operadores gramaticais, assim como o alçamento de certos constituintes semânticos da oração subordinada, que passam a se comportar como constituintes pragmáticos ou sintáticos da oração matriz. ${ }^{14}$

\subsection{A opção por uma perspectiva funcionalista para o tratamento da complementação}

Ao longo da seção que observa o enfoque da tradição gramatical de natureza normativa e descritiva, de um modo geral, pode-se notar que os estudiosos do tema não detalham a estrutura das orações completivas. Com exceção da exposição em Mateus et al. (2003) e em Neves (2002), que consistem numa gramática descritiva, a gramática tradicional e alguns estudos descritivos, como os de Perini (1995) e de Vilela (1999), não demonstram, por exemplo, que tipos de verbos podem selecionar construções finitas ou não-finitas como complemento, ou que fatores semânticos podem motivar o uso de uma ou de outra estrutura de encaixamento. Ainda, nada mencionam sobre, no caso de ambas as construções serem

\footnotetext{
${ }^{14}$ Em relação aos alçamentos, há casos em que um constituinte pertencente, semanticamente, a uma oração subordinada aparece como um constituinte de uma oração hierarquicamente superior. Tal como acontece com o alinhamento, os 'gatilhos' para essa deslocação podem ser de natureza interpessoal, representacional, ou morfossintática (HENGEVELD; MACKENZIE, 2008).
} 
possíveis, que fatores condicionam a seleção/restrição de determinados tipos de complementos. Além disso, não abordam a questão da tendência da língua ao princípio da economia, no caso, preferência pelas estruturas não-finitas. Tal fato gera a falsa impressão sobre a realidade da língua de que maior ênfase é dada às formas finitas. Como bem aponta Decat (1999), no que diz respeito à subordinação, o enfoque tradicional guia-se pela dependência gramatical.

\begin{abstract}
A trajetória dos estudos gramaticais tradicionais (lingüísticos) costuma ser marcada pela utilização da dicotomia coordenação/subordinação na tarefa de descrever e definir os processos de articulação (ou combinação) de cláusulas. Entretanto, é por demais conhecida a insuficiência dos tratamentos tradicionais para dar conta de casos considerados limítrofes, ou mesmo daqueles que aparentemente não oferecem qualquer problema para a análise. Por um lado, opor as noções de coordenação e subordinação não tem sido uma estratégia promissora, por outro, também não o é definir subordinação simplesmente como dependência - e em termos puramente formais. A chamada dependência gramatical [grifo do autor] norteou, de modo geral, os tratamentos tradicionalistas. (DECAT, 1999, p. 300).
\end{abstract}

O que se observa é que os trabalhos que tratam da complementação em geral, seja de uma perspectiva normativa, seja de uma perspectiva descritiva, preocupam-se mais geralmente com os aspectos morfossintáticos, estruturais do processo, restringindo-se, portanto, drasticamente ao postulado de que o nível formal, por si só, determina as relações de complementação. Um enfoque funcional, como o da GDF, dá ênfase especial, no entanto, ao caráter não-autônomo da morfossintaxe na explanação teórica dos fenômenos lingüísticos. Como a GDF vê o componente gramatical como organizado em níveis e camadas, os níveis pragmático, semântico, morfossintático e fonológico acabam desfrutando de saudável autonomia por contarem com categorias próprias, mas também a de interdependência, em virtude de possíveis motivações semânticas e pragmáticas para a codificação morfossintática, que, em grande parte, explicam os fenômenos de alinhamento entre os níveis. Esse postulado de organização gramatical exige um pouco mais de atenção à oposição entre os aparatos formalista e funcionalista. 
A abordagem formal dos fenômenos linguísticos, especificamente a teoria gerativa, baseia-se na existência de estruturas mentais independentes, portanto, consideradas tipicamente inatas. Nesse caso, as propriedades mais profundas do fenômeno linguístico não podem ser depreendidas diretamente dos dados. Os enunciados de textos reais ou transcritos de fala refletem (imperfeitamente) um sistema subjacente que é governado por regras que predizem a forma que assume a unidade linguística idealizada. Para Hengeveld e Mackenzie (2008), o formalismo radical representa uma manifestação extrema desse ponto de vista, já que limita o estudo linguístico à investigação de um sistema totalmente independente do uso.

O funcionalismo, por sua vez, é uma abordagem linguística que se baseia na crença de que as propriedades da expressão linguística adaptam-se às intenções comunicativas do usuário da língua (DIK, 1986). Teorias representativas da abordagem funcional de linha européia são a Gramática Funcional de Dik (1997a, 1997b) - bem como sua arquitetura mais recente, identificada como Gramática Discursivo-Funcional (HENGEVELD; MACKENZIE, 2008) - e a Gramática Sistêmico-Funcional de Halliday (HALLIDAY; MATTHIESSEN, 1999, HALLIDAY, 2004). Há, ainda, nos Estados Unidos, outras duas abordagens no campo funcional: a Gramática do Papel e da Referência de Van Valin (VAN VALIN; LAPOLLA, 1997, VAN VALIN, 2005), mais inclinada para o extremo formal do espectro formal/funcional, e o funcionalismo da Costa-Oeste (que tem estudiosos envolvidos no que vem sendo chamada de abordagem com enfoque no uso (usage-based)), que tende para o extremo mais radicalmente funcional da escala.

O princípio central do funcionalismo é o de que a língua é, acima de tudo, uma forma de comunicação humana em contextos sociocultural e psicologicamente determinados, e esse fato pode determinar a visão de como a língua pode ser modelada (BUTLER, 2008). O sistema da língua como um todo e as estruturas formais que ele usa são, em grande parte, motivados por fatores externos, tais como estruturas cognitivas e fatores sociais de grande 
escala. Há, não obstante, considerável variação no grau em que os fatores explanatórios sociais e cognitivos são priorizados nas diferentes abordagens funcionais.

Qualquer decisão sobre que concepção de gramática assumir equivale a uma tomada de posição metodológica acerca do domínio da sintaxe e de suas relações com outros níveis de análise linguística, particularmente o semântico e o pragmático. Falar de um nível semântico e de um nível pragmático como distinto do morfossintático pressupõe desde já um posicionamento teórico funcional, isto é, não-formalista. Não ser um tratamento formalista, entretanto, não implica critérios valorativos, principalmente como os que, até certo grau, nortearam a polêmica movida entre adeptos das duas posições num passado recente (cf. VOTRE; NARO, 1989; NASCIMENTO, 1990; DILLINGER, 1991), que provocou a noção equivocada de que as duas orientações seriam metodologicamente incomensuráveis e, portanto, excludentes, ideia que, certamente, nem mesmo os protagonistas da controvérsia endossam ainda hoje. A adoção de uma posição teórica funcionalista tem a ver com a ideia de que o objeto de estudos constitui um fenômeno mais probabilístico do que determinístico. Como as probabilidades são de natureza pragmática ou semântica, esse modo de ver, de saída, está mais sujeito a um tratamento funcional. Uma análise desse tipo oferece um conjunto de resultados coerentes se vistos à luz da hipótese de um fundo morfossintático, que é alterado pela superposição de uma figura discursiva, de natureza probabilística.

Do mesmo modo como muitas dicotomias no campo da linguística são válidas, a divisão entre funcional e formal pode também ser, até certo ponto, válida, mas há uma relação um tanto mais complexa entre essas duas abordagens que, segundo Butler (2003), não deve ser ignorada. Há uma escala que vai do modelo de Chomsky até as proposições funcionalistas radicais, como as 'gramáticas emergentes' de Hopper (1987, 1992). Um modo mais realista de se pensar em teorias formais e funcionais é, segundo Butler (2003), em termos de um espectro: num extremo, estão as teorias fundamentalmente formais, como a linguística de 
Chomsky, e, no outro extremo, as teorias radicalmente funcionais; entre esses dois extremos, há uma variedade significativa de abordagens. Na realidade, o que se tem é uma escala de teorias que (i) podem compartilhar boa parte dos objetivos e hipóteses; (ii) encontram-se fechadas em um espaço multidimensional definido por um conjunto complexo de características (cf. BUTLER, 2003).

(1-7) Escala das teorias: do extremo formal ao extremo funcional (cf. BUTLER, 2008, p. 149)

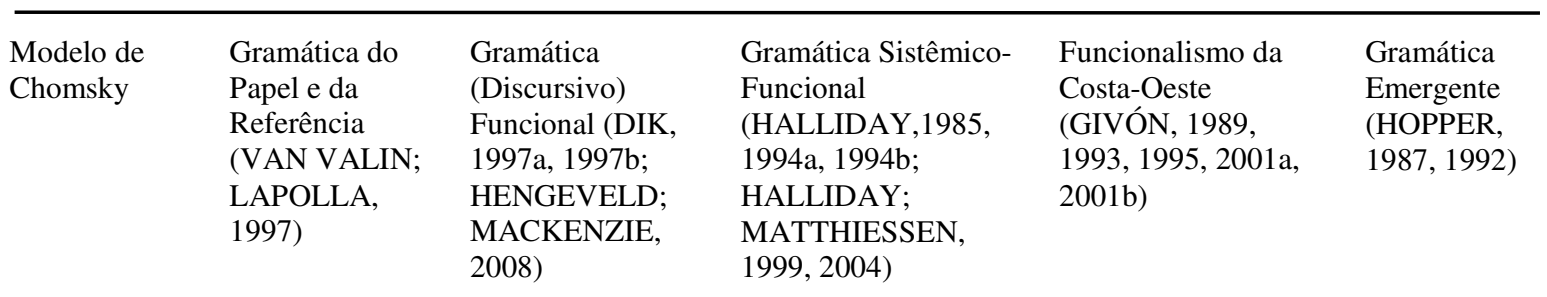

Como aponta Butler (2003), o termo funcional é frequentemente visto como oposto ao termo formal. No entanto, a ambiguidade no uso do termo formal é uma das razões por que o uso dos termos formal e funcional não pode ser considerado esclarecedor, principalmente quando aplicados aos dois paradigmas alternativos. De acordo com Newmeyer (1998), o termo formal pode referir-se tanto à forma ou estrutura gramatical em oposição ao significado ou uso, quanto à utilização de um sistema notacional para expressar de modo preciso e exato as observações e as generalizações linguísticas. Nuyts (1992) vale-se dessa segunda acepção para afirmar que qualquer intenção de modelar um objeto requer formalização, traço metodológico que não pode ser, assim, restrito às teorias formalistas, já que também os funcionalistas empregam sistemas matemáticos de notação.

A polêmica em torno dos termos formal e funcional oculta, portanto, o fato de que diferenças de formalização não passam de mera questão de grau. Alguns modelos funcionalistas consistem em teorias com um elevado grau de formalismo e explicitude notacional, como é o caso, por exemplo, da Gramática (Discursivo) Funcional e da Gramática do Papel e da Referência - os modelos mais próximos à gramática formal de Chomsky, de 
acordo com a escala em (1-7). A diferença real não está na utilização de sistemas notacionais, mas no grau de independência ou de autonomia das relações formais ou gramaticais em relação ao significado e ao uso que os falantes fazem delas no contexto comunicativo. É justamente nesse sentido preciso do termo formal que a diferença entre as gramáticas formais e as funcionais deixa de ser uma questão relativa para ser uma questão absoluta.

Hengeveld (1998) defende a ideia de que os termos formalismo e funcionalismo não são inteiramente adequados, já que incorporam dois diferentes tipos de oposição. A primeira oposição consiste na perspectiva básica adotada pelas teorias linguísticas, mediante a qual a gramática pode ser considerada ou como um sistema estrutural autônomo ou como um instrumento de interação social. Teorias com cada uma dessas duas orientações podem ser chamadas autônomas e funcionais, respectivamente. De acordo com a segunda oposição, algumas teorias linguísticas manifestam o objetivo explícito de construir um sistema de representação formal, enquanto, para outros enfoques, esse objetivo não tem relevância; teorias desse tipo podem ser chamadas de formalizadas e não-formalizadas, respectivamente. Essas oposições podem ser combinadas na forma como mostra a Figura 1-2:

\begin{tabular}{|c|c|c|}
\cline { 2 - 3 } \multicolumn{1}{c|}{} & Formalizada & Não-formalizada \\
\hline Autônoma & $\mathrm{A}$ & $\mathrm{B}$ \\
\hline Funcional & $\mathrm{C}$ & $\mathrm{D}$ \\
\hline
\end{tabular}

Figura 1-2: Funcionalismo e formalismo: autonomia e formalização (cf. HENGEVELD, 1998)

Na Figura 1-2, há quatro diferentes tipos de teorias linguísticas que podem ser distinguidos com base em duas oposições. O tipo A de teoria, formalizado e autônomo, caracteriza o modelo gerativo. O tipo oposto, D, funcional e não-formalizado, pode ser exemplificado por enfoques como os defendidos por Halliday (1985), Givón (1990) e Hopper (1987, 1992). O tipo B, não-formalizado e autônomo, apesar de ser logicamente possível, não 
parece ter nenhum representante significativo; conforme afirma Camacho (2009), talvez nele se enquadre o estruturalismo saussureano. O tipo $\mathbf{C}$, formalizado e funcional, é o enfoque representado pela Teoria de Gramática Funcional (DIK, 1997a, 1997b) - bem como pela nova versão do modelo (cf. HENGEVELD; MACKENZIE, 2008) e pela Gramática do Papel e da Referência (FOLEY; VAN VALIN, 1984). ${ }^{15}$ Essas oposições estão em consonância com a escala de teorias proposta por Butler (2008), tal como mostra (1-7).

Um ponto de concordância entre os funcionalistas tem sido a rejeição da alegação formalista de que a sintaxe é autossuficiente e, assim, autônoma, em relação à semântica e à pragmática. Croft (1995) reconhece quatro 'tipos' de funcionalistas, no que diz respeito à posição formalista de sintaxe autossuficiente e autônoma:

(i) funcionalistas autônomos: aceitam o ponto de vista dos formalistas de que a sintaxe é arbitrária e autossuficiente, embora reconheçam que algumas restrições na estrutura das sentenças podem derivar do discurso;

(ii) funcionalistas/formalistas mistos: consideram a sintaxe arbitrária, mas não autossuficiente, e combinam categorias e características formais e funcionais;

(iii) funcionalistas tipológicos: recusam a ideia de que a sintaxe seja autossuficiente e fazem distinção entre as propriedades universais das gramáticas de base funcional, em termos de hierarquias implicacionais, e a arbitrariedade das características específicas das línguas;

(iv) funcionalistas extremistas: rejeitam tanto a noção de arbitrariedade quanto a de sintaxe autossuficiente. $^{16}$

No que tange especificamente à subordinação, a seção anterior mostrou que o aparato formal, na abordagem de Chomsky (1981, 1986), bem como na de Rosenbaum (1967) e de

\footnotetext{
${ }^{15}$ Segundo Garcia Velasco (2003), um dos maiores êxitos da Teoria da Gramática Funcional é a capacidade de integrar considerações funcionais e comunicativas na própria arquitetura do modelo sem renunciar a um alto grau de formalização.

${ }^{16}$ Para Butler (2003), as correntes (i) e (ii) não são fundamentalmente funcionais e não representam, portanto, o que ele concebe como 'funcionalismo'.
} 
Bresnan (1970, 1979), tem uma concepção puramente sintática das relações de complementação. Desse modo, a relação entre oração matriz e subordinada é tratada em termos de configurações sintáticas que são estabelecidas para os constituintes de uma língua de acordo com a estrutura formal de seus complementos. Em uma concepção sintáticosemântica (GRIMSHAW, 1979), as relações de complementação são determinadas, em primeiro lugar, por traços sintáticos, cabendo à informação semântica dos constituintes apenas um papel adicional (cf. FABER; USÓN, 1999).

Diferentemente do aparato formal, o aparato funcional está mais interessado nos predicados encaixadores por considerar que os fatores determinantes das formas de complementação são de ordem semântica e que, a partir dos significados dos constituintes, os contextos de complementação se tornam altamente previsíveis. O tratamento funcionalista da subordinação completiva está em geral mais voltado para as motivações semânticopragmáticas em torno do predicado do estado de coisas independente do que para as regras puramente estruturais que permitem gerar construções sintaticamente complexas a partir da relação entre predicado e complemento. Isso significa que, na determinação do tipo de completiva, a morfossintaxe não atua sozinha.

No domínio funcional, o que determina a forma da completiva é a configuração semântica do predicado matriz. Como observado por Givón (1990), a semântica das relações completivas pode ser geralmente expressa em relação à semântica do predicado que codifica o estado de coisas principal e, uma vez que predicados constituem o mecanismo prototípico usado para referir-se ao estado de coisas (cf. HOPPER; THOMPSON, 1984), é a semântica do predicado independente que exerce o principal papel no estabelecimento das propriedades semânticas gerais do estado de coisas complexo.

Metodologicamente, este trabalho está comprometido com motivações da expressão morfossintática que são derivadas da pragmática e da semântica. Tal postura o insere 
definitivamente no âmbito dos trabalhos funcionalistas. Adotar uma perspectiva funcional é metodologicamente relevante, já que é comum ver a complementação representada apenas por orações finitas e, quando muito, por orações não-finitas nas gramáticas. Essa situação conflita com a posição que se adota aqui de incluir a nominalização no rol de construções não-finitas que podem, similarmente aos verbos correspondentes, representar algumas categorias como possíveis orações subordinadas. É preferível considerar a complementação como um domínio funcional para ver se restrições semânticas motivam a codificação morfossintática final.

Adicionalmente, a posição funcionalista adotada requer um ponto de vista empírico, o que significa comprometer-se com a interpretação de dados reais de conversação. Esse tratamento empírico envolve uma análise quantitativa e qualitativa dos dados, conforme os Capítulos 5 e 6 apresentarão.

\section{- Breve recapitulação}

Este capítulo iniciou a parte em que se definirão aspectos diversos do posicionamento teórico. Forneceu-se o tratamento dispensado à complementação por enfoques alternativos de gramática - a tradição gramatical, o aparato formalista e o aparato funcionalista. Esse tratamento demonstra que os trabalhos que tratam da complementação em geral, tendo em vista as gramáticas normativas e descritiva e o aparato formalista, preocupam-se mais com questões relacionadas à sintaxe, de modo tal que a sintaxe, por si só, determina as relações de complementação. Em oposição, o enfoque funcionalista dá ênfase especial ao caráter nãoautônomo da morfossintaxe na explanação teórica dos fenômenos linguísticos. O panorama geral do tratamento delegado ao fenômeno sob análise a partir de diferentes concepções tem sua relevância garantida na justificativa da opção por um aparato funcional na investigação, fato que abre caminho para o próximo capítulo demonstrar que o enfoque teórico funcionalista fornece meios para tratar do fenômeno da complementação, com vistas às motivações que determinam a seleção/restrição de determinados tipos de completivas. 


\section{CAPÍTULO 2}

\section{A COMPLEMENTAÇÃO NA PERSPECTIVA FUNCIONAL}

\subsection{Considerações iniciais}

O tema central e condutor deste trabalho - tipos de orações completivas e, por conseguinte, a seleção/restrição de construções mediante fatores semânticos - somente é possível no interior de um aparato teórico que considere que a expressão linguística, morfossintática, não é arbitrária e formalmente autossuficiente, autônoma, mas é o resultado, ao menos parcial, da atuação de princípios semânticos e pragmáticos. Os aspectos formais da linguagem são vistos, desse modo, não como constituintes de um sistema autônomo, que basta a si próprio, mas diretamente vinculado a fatores não essencialmente restritos ao nível morfossintático da gramática.

Dando continuidade ao capítulo anterior, este capítulo e o próximo têm a missão de demonstrar que o enfoque teórico funcionalista abriga satisfatoriamente uma análise dos tipos de orações completivas centrada nas motivações funcionais, mais especificamente, nas motivações semânticas que se estabelecem entre o predicado encaixador e o complemento.

Para demonstrar que o enfoque teórico funcionalista dá conta do tipo de estudo aqui postulado, a organização deste capítulo inclui, primeiramente, a apresentação dos critérios utilizados para as relações de complementação, com base em Cristofaro (2003). No Capítulo 1, ao longo da seção 1.4 (p. 37), mostrei como as noções de subordinação e encaixamento são tratadas no âmbito dos trabalhos orientados pelo enfoque funcionalista. Neste trabalho, muito embora os termos complementação, subordinação e encaixamento sejam usados intercambiavelmente para fazer referência à relação entre os tipos de construções que figuram como complemento e os predicados que funcionam como matriz, adoto um critério funcionalcognitivo para as relações de complementação. 
Como já mencionado, nas relações de complementação, os fatores que determinam a seleção/restrição do complemento são, sobretudo, de ordem semântica. Tal postura se coaduna com os postulados de Givón (1980, 1984, 1989, 1990), Noonan (1985), Dik (1997b) e Cristofaro (2003), que consideram serem semânticos os fatores determinantes das formas de complementação, e que, a partir dos significados dos constituintes, os contextos de complementação se tornam altamente previsíveis. Diante disso, num segundo momento, o plano geral para este capítulo inclui tratar da relação entre predicado encaixador e oração completiva e, especificamente, dos tipos de construções completivas no âmbito de estudos funcionalistas.

Para dar conta dessa proposta, este capítulo segue o seguinte roteiro: a seção 2.2 tem por finalidade apresentar a noção funcional-cognitiva de subordinação defendida por Cristofaro (2003) e adotada neste trabalho; a seção $\mathbf{2 . 3}$ apresenta a semântica da complementação a partir da perspectiva de estudos funcionalista que tratam da relação entre predicado encaixador e predicado encaixado; em seguida, na seção 2.4, o foco recai sobre os tipos de construções que funcionam como complemento de orações hierarquicamente superiores, com base no tratamento que Noonan (1985), Koptjevskaja-Tamm (1993), Mackenzie (1996), Dik (1997b), Cristofaro (2003) e Malchukov (2004) dão ao tema; a seção 2.5, finalmente, faz um balanço geral das perspectivas teóricas funcionalistas para a complementação, de modo a justificar o enquadramento teórico que lança luz à análise apresentada neste trabalho.

\subsection{O critério funcional-cognitivo para as relações de complementação}

Cristofaro (2003) apresenta um estudo tipológico translinguístico dos sistemas de subordinação. Nesse trabalho, a autora segue a mesma linha de Givón (1980, 1990), Noonan (1985) e Hengeveld (1998). Entretanto, diferentemente desses outros trabalhos, a perspectiva 
de Cristofaro (2003) representa a primeira tentativa sistemática de atribuir os três tipos de relação de subordinação - completivas, adverbiais e relativas - aos mesmos princípios funcionais. Como o enfoque de Cristofaro é tipológico, o objetivo de seu estudo é descobrir os mecanismos relacionais subjacentes entre as estruturas morfossintáticas de que as línguas dispõem e as situações conceituais que elas expressam em seus respectivos domínios funcionais.

Para Cristofaro (2003), a subordinação é geralmente definida com base em critérios morfossintáticos, como o de dependência e o de encaixamento de orações. Outro critério morfossintático tradicionalmente invocado para definir a subordinação é o uso de formas verbais não-finitas, como infinitivos, gerúndios e particípios. Ocorre que as diferentes línguas podem codificar diferentemente as relações de complementação. ${ }^{17}$

Conforme repetidamente apontado na tradição tipológica, a relação entre o tratamento descritivo, intrassistêmico, e o tratamento tipológico, transsistêmico, mostra que critérios morfossintáticos têm uma aplicabilidade limitada na comparação transsistêmica, uma vez que as mesmas estruturas morfossintáticas não são universalmente compartilhadas. Como nem todas as línguas dispõem, por exemplo, de orações encaixadas ou formas verbais não-finitas para expressar uma relação particular entre dois estados de coisas, o estudo tipológico não pode basear-se em critérios morfossintáticos, porque isso significaria excluir todas as línguas que dispuserem de um modo diferente de codificar a noção relevante.

Aplicando-se o mesmo princípio ao tratamento intrassistêmico, pode-se dizer que o fenômeno sob investigação - as diferentes estratégias para a construção de orações completivas - deve ser definido de um modo estruturalmente independente, isto é, em termos funcionais, ou melhor, em termos nocionais, cognitivos, e semântico-pragmáticos. Adotar uma perspectiva tipológico-funcional é metodologicamente relevante, mesmo para um estudo

\footnotetext{
${ }^{17}$ Cristofaro (2003) menciona que há línguas em que a oração dependente na relação de complementação não atua como um argumento do predicado principal e não está encaixada. É o caso, segundo a autora, da língua muna, que expressa relações de complementação por meio da justaposição de orações.
} 
intrassistêmico, já que, como foi mencionado, é comum ver a complementação representada apenas por orações finitas e, quando muito, por orações não-finitas nas gramáticas, fato que é inconciliável com a posição que se adota aqui de incluir a nominalização no rol de construções não-finitas que podem representar algumas categorias como possíveis casos de subordinação.

De acordo com um critério funcional-cognitivo, desenvolvido por Cristofaro (2003), a partir de Langacker (1991), a subordinação consiste num modo de construir uma relação cognitiva entre dois estados de coisas, de um modo tal que a um deles, o estado de coisas dependente, falta um perfil autônomo, sendo, por isso, construído a partir da perspectiva do outro estado de coisas, o estado de coisas principal.

O traço distintivo do enfoque conceitual de Cristofaro (2003) é a tentativa de relacionar a subordinação não a propriedades específicas dos tipos individuais de ligação oracional, mas ao modo como os estados de coisas expressos por orações ligadas são percebidos e conceitualizados e ao estatuto que têm no contexto discursivo, uma vez que esse enfoque funcional estabelece uma nítida distinção entre o nível conceitual em sentido amplo (semântico, pragmático e cognitivo) e o nível morfossintático. A subordinação é encarada como o resultado de situações conceituais particulares em vez de um fenômeno morfossintático. Orações que codificam um estado de coisas dependente são consideradas orações dependentes e, similarmente, orações que codificam um estado de coisas independente são consideradas orações independentes, ou orações principais.

Cristofaro parte do postulado da assimetria, desenvolvido por Langacker (1991), para definir subordinação, mencionando que, ao construir a conexão entre dois estados de coisas, um falante tem duas escolhas:

(i) os dois estados de coisas podem ser construídos como perfeitamente simétricos de um ponto de vista cognitivo, de modo tal que ambos têm um perfil autônomo, uma situação em 
que ocorre com a coordenação perfeitamente simétrica em que nenhum perfil oracional sobrepuja o outro, como em (2-1):

(2-1) O Santos venceu e o Corinthians perdeu.

(ii) os dois estados de coisas são construídos como cognitivamente assimétricos, quando um dos dois prescinde de um perfil autônomo e é construído com base na perspectiva do outro. Por isso, Langacker (1991) diz que uma sentença como (2-2) designa o processo de conhecimento, não o de ter partido ou deixado de partir. Nesse caso, o estado de coisas subordinado perde o perfil autônomo, enquanto o estado de coisas principal impõe seu próprio perfil, sobrepondo-se ao conjunto total da sentença.

(2-2) Eu sei que ela partiu.

A distinção entre subordinação e não-subordinação, tal como desenvolvida por Langacker (1991), é paralela à distinção pragmática entre asserção e não-asserção, vista não sob uma perspectiva lógico-semântica, mas sob uma perspectiva pragmática. A interpretação pragmática refere-se não a condições de verdade, mas ao que o falante assume em relação ao estatuto informacional das sentenças que ele enuncia (CRISTOFARO, 2003).

Ao enunciar, por exemplo, uma sentença como (2-3a), assume-se que a oração que contém o predicado de enunciação afirmar é a parte asseverada da sentença, enquanto o estado de coisas sobre a legalidade da operação é a parte não-afirmada ou pressuposta.

(2-3)a. Protógenes afirmou que a operação Satiagraha é legal.

É Cristofaro (2003) quem equaciona a noção de subordinação e a de nãosubordinação, definidas por Langacker (1991), ao critério de assertividade e nãoassertividade, já que Langacker prefere ater-se apenas ao postulado de uma relação cognitiva 
assimétrica entre dois estados de coisas, tal que um impõe seu próprio perfil a toda a sentença, enquanto o outro é destituído de um perfil autônomo.

Relacionar a falta de um perfil autônomo com não-assertividade fornece critérios consistentes para a identificação da subordinação. Em outros termos, trata-se de um critério que fornece uma definição absolutamente independente de propriedades estruturais de qualquer oração particular de uma língua dada.

O método para detectar como essa propriedade cognitiva de base pragmática define uma oração dependente pode basear-se nos testes de assertividade disponíveis na literatura, como o de que parte de uma sentença está aberta a polêmica por meio de uma negação sistemática e da mudança da força ilocucionária da sentença, como no caso de perguntas e das chamadas 'questions-tags':

(2-3)b. Não é verdade que Protógenes afirmou que a operação Satiagraha é legal.

c. É verdade que Protógenes afirmou que a operação Satiagraha é legal?

d. Protógenes afirmou que a operação Satiagraha é legal, não afirmou?

e.* Protógenes afirmou que a operação Satiagraha é legal, não é legal?

Segundo Cristofaro (2003), o principal ponto que merece ser enfatizado é o de que testes de assertividade são operacionais para qualquer língua, porque não se referem a tipos específicos de estrutura morfossintática, mas ao estatuto pragmático/cognitivo de diferentes partes da sentença. Como eles checam que parte da sentença está sujeita a polêmica, eles são independentes dos traços estruturais e, por conseguinte, o postulado da assimetria acaba tendo uma grande utilidade na análise transsistêmica da subordinação completiva e, portanto, é aplicável com igual valor à análise intrassistêmica, que se pretende fazer aqui.

O trabalho que aqui se apresenta trata especificamente de uma língua, o português falado no Brasil; não se insere, desse modo, no rol de trabalhos tipológicos sobre complementação, tais como os de Koptjevskaja-Tamm (1993), Cristofaro (2003), Malchukov 
(2004) e Dixon (2006). Entretanto, constitui uma tentativa de, numa análise intrassistêmica, dar uma explicação semântica plausível para a complementação e, mediante o modo como se apresenta esse subsistema morfossintático, classificar o português em relação aos estudos tipológicos sobre a subordinação completiva em direção a princípios universais. A noção da subordinação completiva a partir de uma perspectiva tipológica como essa pode fornecer um quadro mais abrangente, que permita verificar como enquadrar os resultados obtidos nesta pesquisa em relação a outras pesquisas de caráter tipológico. Além disso, permite assumir uma perspectiva neutra, mais objetiva, no equacionamento da complementação no português, que, como se viu, tende a assumir um posicionamento formalista.

Definido o critério funcional-cognitivo para a subordinação, a seção seguinte aborda as relações que se estabelecem entre as orações envolvidas no fenômeno da complementação, isto é, entre predicados encaixadores de complemento e oração completiva.

\subsection{A semântica da complementação: as bases da ligação entre o predicado encaixador de complemento e o tipo de completiva}

\subsubsection{Integração semântica nas relações de complementação}

As relações completivas podem ser identificadas com base no predicado que codifica o estado de coisas principal. A semântica do estado de coisas principal estabelece que tipo de especificação completiva ele requer, de modo que as bases da ligação entre um predicado encaixador e um tipo particular de complemento é a relação semântica existente entre eles.

Givón (1980) considera que a natureza semântica do predicado da matriz pode ser vista como um fator indicativo do grau de integração da oração completiva à oração principal. Em cada classe individual de predicados encaixadores, os diferentes verbos posicionam-se 
diferentemente, dependendo de seus traços semânticos. ${ }^{18}$ Há um alto grau de integração semântica se o agente do estado de coisas principal for capaz de controlar a realização do estado de coisas dependente e se o estado de coisas dependente tem origem em um ato de manipulação deliberado por parte do agente do estado de coisas principal (como é o caso, por exemplo, de predicados como 'fazer'). Também há alto grau de integração semântica se os estados de coisas dependentes compartilham seus referentes e são espacial e temporalmente contíguos.

Givón (1990, p. 256) sugere que a dimensão da integração semântica subjacente é “a integração espácio-temporal de dois eventos em um único esquema de evento". ${ }^{19}$ Em estados de coisas temporal e espacialmente contíguos e em estados de coisas com participantes compartilhados, há um grau maior de integração semântica do que em estados de coisas que não são contíguos temporal e espacialmente. O modo como o grau de integração semântica se reflete na codificação morfossintática está no uso de formas não-finitas, com a nãoespecificação de morfema modo-temporal e de argumentos.

Os diferentes graus de integração entre orações são explicados pelo princípio de iconicidade diagramática, segundo o qual a integração sintática entre as orações reflete iconicamente a integração semântica entre os eventos codificados (cf. HAIMAN, 1983). Em outras palavras, se os dois eventos na oração principal e na oração completiva estiverem integrados em um único evento complexo, as orações estarão codificadas em uma única oração complexa.

Nenhuma oração é totalmente independente de seu contexto oracional imediato em um discurso coerente conectado. Consequentemente, se uma oração coordenada é parte de um discurso coerente, algumas ligações semânticas ou pragmáticas - devem conectá-la ao seu ambiente oracional imediato. E cada ligação de conectividade (coerência) tende a aparecer com dependências gramaticais concomitantes. $\mathrm{O}$ paralelo entre dependência

\footnotetext{
${ }^{18}$ Givón $(1980,1990)$ faz distinção entre três classes de predicados - os verbos manipulativos, os de modalidade (incluindo os volitivos, fasais e implicativos) e os de enunciação-cognitivos (incluindo os de conhecimento, de atitude proposicional e os predicados de enunciação).

${ }^{19}$ Cf. o original: (dimension underlying semantic integration is) the spatio-temporal integration of two events into a single event frame.
} 
interoracional semântica e pragmática ('funcional') e gramatical ('formal') reflete a mesma tendência icônica que notamos na gramática de complementos verbais: iconicidade de integração de eventos e integração de oração: "quanto mais semântica e pragmaticamente dois eventos/estados estão conectados no discurso, mais gramaticalmente integradas estarão as duas orações". (GIVÓN, 1993, p. 286). ${ }^{20}$

Segundo Cristofaro (2003), é a economia sintagmática que explica a correlação entre a predeterminação de traços semânticos entre dois estados de coisas conectados e os fenômenos morfossintáticos que levam à não-especificação de informação correspondente, a que ela denomina Princípio de Recuperabilidade de Informação.

A economia sintagmática é a tendência para reduzir o comprimento ou a complexidade de qualquer enunciado, de modo que as expressões mais frequentes no uso tendem a reduzir-se fonologicamente e a informação que é redundante e/ou recuperável no contexto comunicativo tende a ser omitida. (CRISTOFARO, 2003, p. 248). ${ }^{21}$

A economia sintagmática está fortemente correlacionada com a predeterminação de informação semântica em estados de coisas conectados e a não-manifestação de informação pragmaticamente compartilhada pelos participantes da interação. $\mathrm{O}$ resultado é, segundo Cristofaro (2003), tornar a estrutura linguística o mais transparente possível, em contraposição ao princípio da motivação icônica.

Com a hierarquia de ligação e a tipologia de complementos, Givón (1980) estabelece a relação entre a estrutura semântica do predicado encaixador e a estrutura sintática de seus complementos. Segundo o autor, as categorias semânticas são representadas iconicamente na estrutura da oração completiva. Na escala progressiva de integração semântica, quanto mais as relações entre predicado encaixador e predicado encaixado se dão no polo esquerdo, mais

\footnotetext{
${ }^{20}$ Cf. o original: No clause is totally independent of its immediate clausal context in connected coherent discourse. Consequently, if a conjoined clause is part of a coherent discourse, some strands - semantic or pragmatic - must connect it to its immediate clausal environment. And such strands of connectivity ('coherence') tend to come with concomitant grammatical dependencies. The close parallel between semanticpragmatic ('functional') and grammatical ('formal') inter-clausal dependencies reflects the same iconic tendencies we noted in the grammar of verbal complements: Iconicity of event-integration and clauseintegration: "the more semantically or pragmatically connected two events/states are in the discourse, the more grammatically integrated will the two clauses be".

${ }^{21}$ Cf. o original: Syntagmatic economy is the tendency to reduce the length or complexity of any utterance, so that the most frequent expressions tend to be reduced phonetically and information that is redundant and/or recoverable from the context tends to be omitted.
} 
"independente" é a completiva; em direção oposta, quanto mais as relações de complementação se dão ao no polo direito, mais "lexicalizada" é a completiva, conforme o Quadro 2-1 mostra.

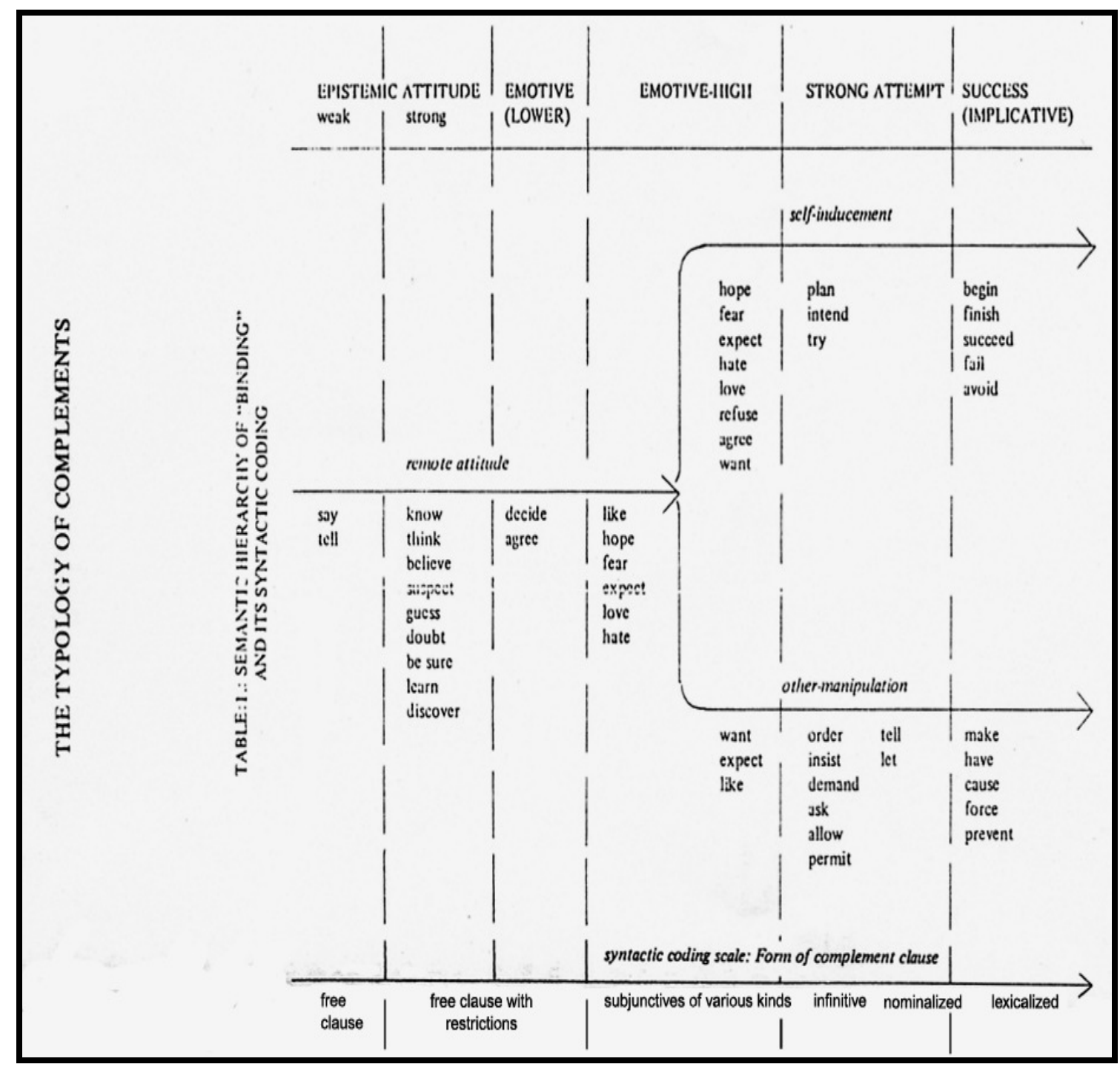

Quadro 2-1: Hierarquia da ligação (GIVÓN, 1980, p. 369)

Em termos de estrutura semântica, os complementos são organizados em três diferentes camadas semânticas, que se sobrepõem - atitude epistêmica, atitude emotiva e implicabilidade. Cada uma dessas camadas se bifurca em categorias mais fracas e mais fortes: atitude epistêmica fraca, atitude epistêmica forte, atitude emotiva fraca, forte tentativa e implicativos. Givón (1980) afirma que as categorias semânticas são representadas 
iconicamente na estrutura da oração completiva. De acordo com a hierarquia, predicados encaixadores de atitude epistêmica tomam complementos 'livres' (isto é, a oração complemento e a oração principal são distinguíveis e independentes uma da outra), enquanto predicados encaixadores implicativos tendem a ocorrer com complementos mais integrados à oração principal, tais como complementos infinitivos e nominalizações. A integração semântica envolve quatro graus estruturais:

(a) colexicalização de dois verbos: relaciona-se ao princípio da proximidade, segundo o qual "quanto maior o grau de proximidade de significado entre duas entidades tanto maior o grau de proximidade temporal no nível do código" (GIVÓN, 1993, p. 24). ${ }^{22}$ Se o verbo da oração matriz pertencer ao nível mais alto da escala de integração de eventos, mais facilmente ele será colexicalizado.

(b) integração relacional do agente do complemento na oração matriz: quanto mais semanticamente incorporada estiver a oração completiva à oração matriz, menos características/marcas de sujeito agente terá a subordinada.

(c) morfologia - finita /não-finita - da completiva: se o verbo está em um ponto elevado de integração de evento, mais nominal será seu complemento. O processo sintático de nominalização pode ser visto como adaptações na estrutura gramatical da oração finita. Quando a oração verbal é ajustada para uma frase nominal prototípica via nominalização, torna-se uma oração não-finita ou uma oração menos finita. ${ }^{23}$ Givón (1993) alega que, na conversão de uma oração finita para não-finita, o verbo antigo se torna o núcleo da oração nominalizada, perde suas inflexões verbais (aspecto-modalidade - concordância) e adquire morfologia como nome (determinantes e modificadores).

\footnotetext{
${ }^{22}$ Cf. o original: The closer two linguistic entities are in meaning, the more they will exhibit temporal proximity at the code level.

${ }^{23}$ Dik (1997b) considera que, no nome deverbal, os constituintes do predicado input (operadores, predicado, argumentos e satélites) devem ajustar-se ao termo nominal prototípico, adotando novos tipos de constituintes (operadores de termo - determinante e quantificador -, sintagma de possuidor, adjetivo, nome).
} 
(d) separação entre as orações por complementizadores: a presença de um complementizador marca um menor grau de integração entre as orações. Quanto mais baixo o ponto em que estiver o verbo da principal na escala de integração de eventos tanto maior será a tendência de ele se separar pelo complementizador. O complementizador é utilizado com verbos do alto da escala de integração, quando duas orações estão sob um mesmo contorno de entoação.

Embora não trate especificamente da relação entre tipo de predicado encaixador e tipo de complemento, a escala de dessentencialização proposta por Lehmann (1988), repetida e renumerada abaixo por conveniência, parece refletir, de certa forma, a hierarquia de Givón (1980).

sentencialidade

nominalidade

oração

construção não-finita

nome verbal

Figura 2-1: Dessentencialização (adaptada de LEHMANN, 1988, p. 189)

O que é interessante é que, tal como na hierarquia de Givón (1980), quanto mais a construção subordinada se aproxima do polo direito do continuum, mais o comportamento dela se aproxima ao de um membro prototípico da classe dos nomes. ${ }^{24}$ Nesse sentido, podese falar de um acréscimo progressivo do grau de nominalidade da oração subordinada, quando elas são reduzidas pelo processo de dessentencialização. Ao final do processo de redução, a oração torna-se um constituinte nominal de uma oração matriz (LEHMANN, 1988).

A integração semântica é também um dos três parâmetros que Cristofaro (2003) considera para descrever a semântica dos vários tipos de relações. A autora defende a classificação das classes de predicados encaixadores de complemento em termos do grau de integração semântica, isto é, em termos da interconexão entre os estados de coisas ligados. O

\footnotetext{
${ }^{24}$ Como parece claro na escala de dessentencialização, além da perda de propriedades sentenciais no verbo, a nominalidade progressiva dota a construção encaixada de propriedades distribucionais do nome, como a possibilidade de combinar-se com adposições e afixos de caso.
} 
componente básico da integração semântica é o grau em que as fronteiras entre esses estados de coisas se 'deterioram' ou se mantêm intactas.

Diferentemente de Givón (1980), Cristofaro (2003, p. 119) acredita que a integração semântica é independente da contiguidade espácio-temporal, "não depende apenas de dois estados de coisas estarem ligados mas do grau em que se dá ligação". ${ }^{25}$ A interligação resulta de uma variedade de fatores, como, por exemplo, do fato de dois estados de coisas serem parte de um mesmo esquema de estado de coisas global. Se dois estados de coisas estão interligados, então, provavelmente, eles serão contíguos espaço-temporalmente, mas a contiguidade espácio-temporal por si só não contribui para a integração semântica.

Givón (1990) considera como outro componente da integração semântica o fato de o participante do estado de coisas principal ter um desejo ou interesse na ocorrência do estado de coisas. Para ele, predicados que envolvem preferência (tais como querer e ordenar) determinam um alto grau de integração entre os estados de coisas interconectados, enquanto predicados que não envolvem preferência estão relacionados a um baixo grau de integração semântica (como os de percepção, conhecimento, atitude proposicional e de enunciação). Cristofaro (2003), entretanto, acredita que um estado de coisas ocorre ou não independentemente do desejo das pessoas. O desejo de alguém de que um estado de coisas ocorra não significa, necessariamente, que provocará algum efeito na ocorrência do estado de coisas. $^{26}$

Além da integração, outros dois parâmetros podem ser estabelecidos na caracterização semântica das relações de complementação, o nível da estrutura da oração em que se estabelece a relação de complementação e a predeterminação de outros fatores semânticos dos estados de coisas ligados, que, de certo modo, é um indicativo de integração semântica.

\footnotetext{
${ }^{25}$ Cf. o original: Semantic integration basically pertains to whether and how much two SoAs are interconnected.

${ }^{26}$ Ao que parece, as considerações de Givón (1990) dizem respeito à preferência ou ao desejo do falante quanto à ocorrência do estado de coisas codificado na oração subordinada e não em relação à ocorrência em si do estado de coisas, tal como contesta Cristofaro (2003).
} 
As diferentes relações de complementação dizem respeito aos diferentes níveis de estrutura da oração. Com base no modelo da Teoria de Gramática Funcional standard (Dik, 1997a, 1997b; Hengeveld, 1989, 1990), Cristofaro considera que a configuração de uma oração que representa um ato de fala contém quatro camadas de análise, e cada uma está completamente contida na imediatamente superior. As relações de manipulação e de percepção pertencem à segunda camada, já que elas se referem à possível ocorrência do estado de coisas. A terceira camada inclui as relações de conhecimento, atitude proposicional e enunciação; estados de coisas em si não são objetos de conhecimento, de pensamento e de discurso indireto, pelo contrário, os conteúdos proposicionais referidos a estados de coisas é que são (Cristofaro, 2003). ${ }^{27}$

Um pouco mais complicados são os predicados modais, os fasais e os volitivos. Cristofaro (2003) acha problemático o modo como a Gramática Funcional (Dik, 1997a, 1997b) trata esses predicados: são considerados operadores que modificam a estrutura interna do estado de coisas a que eles se referem, atuando, assim, na primeira camada (predicados e termos, na versão standard do modelo). Predicados modais e volitivos definem o valor modal do estado de coisas a que eles se referem, enquanto os predicados fasais definem o valor aspectual desse estado de coisas.

Cristofaro (2003) considera, por seu lado, que os predicados fasais agem como operadores aspectuais, mas deles diferem, no sentido de que sua referência não é puramente interna ao estado de coisas relevante. A mesma observação vale para os predicados modais e volitivos. Operadores modais, tais como o modo verbal, definem o valor modal do estado de coisas relevante, independentemente de qualquer outro estado de coisas. Predicados modais e volitivos, por sua vez, relatam a ocorrência do estado de coisas como um todo à situação em que essa ocorrência é necessária, possível ou desejada. Consequentemente, sua referência não

\footnotetext{
${ }^{27}$ A classificação de predicados encaixadores de complementos mencionada por Cristofaro (2003) é tomada de Noonan (1985).
} 
é puramente interna ao estado de coisas relevante, na medida em que ela estabelece uma conexão entre dois estados de coisas distintos: o estado de coisas ao qual a condição modal se aplica, e as circunstâncias que definem a condição modal por si só.

Alguns traços semânticos dos estados de coisas ligados são predeterminados pela natureza da relação de complementação em si. A predeterminação dos fatores semânticos dos estados de coisas ligados diz respeito à referência a tempo, aspecto ou modo e aos participantes do estado de coisas ligado. ${ }^{28}$

Diferentes relações de complementação têm diferentes implicações sobre a referência de tempo, de aspecto ou de modo e participantes do estado de coisas ligado. Os predicados de percepção requerem que os estados de coisas principal e dependente sejam simultâneos; predicados de manipulação, por sua vez, requerem que o estado de coisas dependente seja posterior ao estado de coisas principal; predicados fasais predeterminam a referência de tempo e o valor aspectual do estado de coisas dependente - o tempo e o aspecto precedentes ao estado de coisas principal e os posteriores a ele (GIVÓN, 1973). No que diz respeito aos predicados modais e volitivos, Cristofaro (2003) considera que a referência de tempo e o valor aspectual do estado de coisas dependente não são determinantes para a relação de complementação.

As relações de complementação predeterminam o valor modal do estado de coisas dependente, ainda que de modo diferente. Com predicados modais e volitivos, por exemplo, o valor modal do estado de coisas dependente é irrelevante. Predicados manipulativos, como ordenar, requerem que o estado de coisas dependente não seja realizado no mesmo ponto temporal em que se localiza o estado de coisas principal. Já os manipulativos, como fazer,

\footnotetext{
${ }^{28}$ A noção de participante de Cristofaro (2003) deve ser entendida como equivalente à noção de argumento, tal como proposto pela GF (DIK, 1997a, 1997b) e pela GDF (HENGEVELD; MACKENZIE, 2008). Na G(D)F, o termo participante é empregado para designar o Falante e o Ouvinte, isto é, os participantes do processo de interação verbal, que, como tais, são categorias pragmáticas do Nível Interpessoal e não categorias semânticas do Nível Representacional, como a noção de Cristofaro sugere. Isso significa que, apesar de utilizar a terminologia de Cristofaro, ao fazer referência aos participantes do estado de coisas principal e do estado de coisas dependente, estou, na verdade, tratando dos argumentos envolvidos na relação que se estabelece entre os dois estados de coisas.
} 
requerem que o estado de coisas dependente realize-se como um resultado do ato da manipulação descrita pelo predicado. Por isso, o estado de coisa dependente é conhecido como factual, assim como também o são os predicados de percepção e os de conhecimento embora, nesse caso, o valor modal seja definido indiretamente.

Predicados de conhecimento requerem que o conteúdo proposicional relevante seja apresentado como verdadeiro; consequentemente, o estado de coisas correspondente ao conteúdo proposicional é apresentado como factual. Com predicados de atitude proposicional, por sua vez, o conteúdo proposicional representando o objeto do predicado encaixador de complemento nunca é apresentado nem com verdadeiro nem como falso; como consequência, o valor modal do estado de coisas correspondente é predeterminado como não-factual. O mesmo acontece com os predicados de enunciação. Desse modo, na medida em que eles envolvem a relação entre dois estados de coisas distintos, Cristofaro (2003) postula que esses predicados pertencem ao nível da predicação e não ao do predicado, tal como defende a GF.

Algumas relações de complementação também são predeterminadas pelos participantes do estado de coisas dependente. Esse tipo de predeterminação ocorre, segundo Cristofaro (2003), com predicados fasais, manipulativos e modais. Na visão da autora, outros predicados encaixadores de complemento, como os volitivos, de percepção, de conhecimento, de atitude proposicional e de enunciação, não têm vínculo com os participantes do estado de coisas dependente.

O que se vê é que, em termos de integração semântica, os estados de coisas principal e dependente numa relação de subordinação podem ter vários graus de interconexão, no que diz respeito ao compartilhamento de marcação de tempo, aspecto modo e também de participantes (GIVÓN, 1980, 1990; NOONAN, 1985; CRISTOFARO, 2003). Com base nesse parâmetro, Cristofaro (2003) propõe uma relação entre predicados encaixadores e integração semântica, tal como aparece no Quadro 2-2: 


\begin{tabular}{|l|l|}
\hline a Hierarquia da integração semântica & Sem integração semântica \\
\hline $\begin{array}{l}\text { Fasais > Modais > Manipulativos ('fazer') > } \\
\text { Manipulativos ('ordenar'), Volitivos e de }\end{array}$ & Enunciação \\
Percepção & \\
em que '>' significa 'envolve maior grau de integração \\
semântica do que'
\end{tabular}

Quadro 2-2: Integração semântica (adaptado de CRISTOFARO, 2003, p. 122)

A relação entre os três parâmetros sugeridos por Cristofaro, os quais, de certo modo, coadunam com os graus de integração sugeridos por Givón (1980, 1990), pode ser assim sintetizada: quanto maior o grau de integração semântica entre a predicação dependente e a independente, tanto maior o grau de predeterminação semântica e, por conseguinte, tanto menor a quantidade de referência formal às categorias de tempo, aspecto e modo, por um lado, e a de participantes, por outro. Como se vê, esses parâmetros de integração são cruciais para determinar o grau de nominalidade/verbalidade de um predicado, por um lado, e o grau em que as construções possíveis constituem, de fato, alternativas disponíveis para a seleção consciente do falante.

Como a categoria semântica do predicado encaixador é um fator importante para a seleção de determinado tipo de oração subordinada completiva, abordo, a seguir, alguns tipos de classificação semântica de predicados encaixadores de complemento.

\subsubsection{Tipos semânticos de verbos e tipos de completivas: classificação das construções segundo a semântica do predicado encaixador}

Muitos estudos que tratam do fenômeno da complementação abordam, em geral, as propriedades semânticas do predicado encaixador em relação à oração completiva. Como já mencionado, Givón (1980) considera que a natureza semântica do predicado encaixador pode ser vista como um fator indicativo do grau de integração da oração subordinada à oração 
matriz. Dik e Hengeveld (1991) e Hengeveld (1998) fazem referência ao fato de que, no caso de complementação, a natureza da representação subjacente do complemento oracional depende semanticamente do predicado encaixador. Hengeveld e Mackenzie (2008) postulam que diferentes predicados encaixadores requerem diferentes tipos de complementos, cuja classificação depende da camada em que estão contidos. Entende Cristofaro (2003) que as relações completivas se identificam com base no predicado que codifica o estado de coisas principal e a semântica do predicado estabelece que tipo de especificação será requerido. Dixon (2006) considera que a discussão sobre complementação é mais eficaz se se reconhece que os lexemas de muitas línguas são naturalmente sensíveis a um número de tipos semânticos; adicionalmente, considera que a complementação envolve dois tipos de verbos, o encaixador de complemento e o verbo na oração complemento.

No estudo do português, Gonçalves et al. (2008) correlacionam os aspectos semânticos do predicado encaixador ao tipo de complemento apresentado, postulando que as sentenças encaixadas recebem seu enquadramento semântico do predicado matriz em que elas se encaixam e que a semântica do predicado matriz é um dos fatores determinantes do formato que assumem as orações encaixadas. Braga (2008) postula que a correlação entre a forma de expressão do complemento e a sua camada de representação leva em consideração os tipos de predicados encaixadores que introduzem as diferentes unidades linguísticas.

Sousa (2007), que investiga o comportamento das orações completivas introduzidas pela conjunção se em textos escritos do português arcaico, moderno e contemporâneo, postula que as orações completivas desse tipo sejam tratadas como diferentes unidades semânticofuncionais. Em consequência, propõe que o estudo das propriedades semânticas das orações completivas tem pouca validade se for feito exclusivamente com base no significado do predicado encaixador. 
[...] em grande parte dos estudos sobre as construções completivas, o predicado matriz tem recebido uma atenção maior do que o complemento oracional. Ao se descreverem propriedades semânticas dos predicados complementáveis por oração, por exemplo, o conteúdo da oração completiva tem apenas um papel auxiliar na caracterização dos predicados. (SOUSA, 2007, p.56).

Discordo da posição de Sousa (2007) no que diz respeito à relevância do significado do predicado encaixador. A análise do tipo de entidade representado pela completiva, tal como faço neste trabalho e se faz em outros que tratam do fenômeno em questão, não pode prescindir da análise do significado do predicado encaixador. Observem-se os exemplos em $(2-4)$ e $(2-5)$ :

(2-4) Ana sabe que Alfredo se casou.

(2-5) Ana disse que Alfredo se casou.

Nos termos da GDF - que será tratada no próximo capítulo, a oração Alfredo se casou, que figura como complemento de saber, em (2-4), e de dizer, em (2-5), é de natureza diferente em (2-4) e (2-5). Como resultado de um construto mental, designado por saber, a completiva em (2-4) é classificada como entidade de terceira ordem, avaliada em termos de sua verdade. A completiva em (2-5), por sua vez, caracteriza-se pela função precípua de introduzir um conteúdo comunicado.

A classificação da sentença Alfredo se casou como um conteúdo proposicional ou como um conteúdo comunicado, isto é, como unidades semântico-funcionais, somente é possível a partir da verificação do predicado que toma essa sentença como complemento. Isso significa que a questão reside, principalmente, na característica semântica do verbo da oração matriz que determina o esquema semântico de complementação:

Em Hengeveld (1988, 1989, 1990b), Dik (1989), Bolkestein (1990), em consonância com Foley e Van Valin (1985) e Lehmann (1988), argumentase (i) que cada camada (incluindo todas as camadas de menor complexidade que ela contém), pode se tornar complemento de um predicado matriz, (ii) que a camada particular escolhida depende da classe de predicados matrizes envolvidos, e (iii) que as diferenças entre os tipos de 
complementos podem-se explicar em termos de diferenças entre as camadas a eles subjacentes. (DIK; HENGEVELD, 1991, p. 234, grifo meu) ${ }^{29}$

Ainda que se faça uma leitura a partir do significado do complemento, como, por exemplo, 'complementos que designam uma entidade de terceira ordem/conteúdo proposicional não ocorrem com predicados que descrevem um estado de coisas', de qualquer modo, há de se levar em consideração a semântica do predicado encaixador (cf. GIVÓN, 1980, 1995; NOONAN, 1985; CRISTOFARO, 2003; DIXON, 2006; EGAN, 2008; HENGEVELD; MACKENZIE, 2008). Na mesma linha de trabalhos como os de Dik (1997b), Dik e Hengeveld (1991) e Hengeveld $(1989,1996)$, reafirmo que, para os propósitos deste trabalho, a semântica do predicado encaixador é altamente relevante para a determinação do tipo de completiva. Justamente por isso, parto de um conjunto de predicados encaixadores para verificar de que modo se dá essa determinação. A classificação considerada neste trabalho para os predicados encaixadores coincide com as classificações geralmente propostas pela literatura que se baseiam em critérios semânticos e pragmáticos das construções.

O critério de seleção do conjunto de predicados encaixadores baseou-se, primeiramente, numa abordagem classificatória com uma perspectiva tipológica de análise. Isso porque trabalhos desse tipo são funcionalmente dirigidos, ou seja, para dar conta das diferentes construções gramaticais nas diferentes línguas, apelam para alguns domínios funcionais (semânticos, pragmáticos etc.) e observam como esse domínio é representado morfossintaticamente em cada língua analisada. Em segundo lugar, tendo em vista o universo de investigação, optei por uma classificação que considerasse os aspectos particulares dos

\footnotetext{
${ }^{29}$ Cf. o original: In Hengeveld (1988, 1989, 1990b), Dik (1989), Bolkestein (1990) it is argued, in line with Foley and Van Valin (1985) and Lehmann (1988) (i) that each layer (including all layers of lower complexity it contains) may be turned into the complement of a matrix predicate, (ii) that the particular layer chosen is dependent upon the class of matrix predicates involved, and (iii) that differences between complement types can be accounted for in terms of the differences between the layers underlying them.
} 
tipos de predicado encaixador e abrangesse o maior número possível de predicados detectados na amostra. ${ }^{30}$

A seção anterior mostrou que, em sua classificação, Givón (1980) estabelece uma relação entre a estrutura semântica do predicado encaixador e a estrutura sintática de seus complementos. A semântica do predicado encaixador pode estabelecer uma hierarquia, translinguística e rígida, que, sistematicamente, descreve essa relação. Conforme apresentado na seção anterior, em termos de estrutura semântica, os complementos são organizados em três diferentes camadas, que se sobrepõem - atitude epistêmica, atitude emotiva e implicabilidade. Cada uma dessas camadas se bifurca em categorias mais fracas e mais fortes (cf. seção 2.3.1, Quadro 2-1, p. 63):

(i) atitude epistêmica fraca (say e tell)

(ii) atitude epistêmica forte (know, think, believe, guess, learn, discover, doubt)

(iii) atitude emotiva fraca (decide, agree)

(iv) atitude emotiva forte (like, hope, fear, expect, love, hate, want)

(v) forte tentativa (plan, intend, try, order, insist, demand, ask, allow, permit, tell, let)

(vi) implicativos (begin, finish, succeed, fail, avoid, make, have, force, prevent)

Embora perfeitamente aplicável ao estudo que aqui se propõe, a classificação de Givón (1980) não inclui, por exemplo, predicados teoricamente relevantes para o tipo de fenômeno aqui investigado, como os de percepção, ver e ouvir. Considerando, portanto, outra proposta de classificação mais abrangente que a de Givón, examinei a de Noonan (1985), utilizada por Cristofaro (2003). Segundo o autor, todas as línguas têm o mesmo conjunto de usos de predicados encaixadores e seus complementos, mas diferem entre si quanto ao

\footnotetext{
${ }^{30}$ No Capítulo 4, trata-se especificamente do universo de investigação e procedimentos metodológicos. Nesta seção, pretende-se somente enfatizar a importância do predicado encaixador na determinação da forma do complemento e, com base nisso, apresentar algumas classificações de predicados disponíveis na literatura sobre o assunto e optar por uma.
} 
número e tipo de complemento disponível.

Baseando-se em Noonan (1985), Cristofaro (2003) apresenta as seguintes classes de predicado que envolvem diferentes tipos de relações entre o estado de coisas principal e o dependente ${ }^{31}$ :

(i) modais (must, can, may, be able)

(ii) fasais (begin, continue, stop)

(iii) desiderativos (want, wish, hope)

(iv) manipulativos (make, force, press, order, ask)

(v) perceptivos (feel, see, hear)

(vi) de conhecimento (know, realize, see, hear [alguns usos])

(vii) de atitude proposicional (think, doubt, believe)

(viii) de enunciação (say, tell, report,promise, ask)

Comparado à proposta de Givón (1980), o leque de predicados encaixadores, proposto por Noonan (1985) e Cristofaro (2003), tem maior abrangência com o acréscimo, por exemplo, de predicados encaixadores modais e perceptivos, mas Cristofaro (2003) não inclui alguns tipos de predicados que envolvem atitude emotiva forte, como gostar, por exemplo, ou de forte tentativa, como tentar, que, como os de percepção, podem ter influência significativa na seleção do predicado encaixado.

\footnotetext{
${ }^{31}$ Os cinco primeiros tipos de predicados encaixadores estão no nível da predicação, segundo Cristofaro (2003), enquanto os três últimos estão no nível da proposição.
} 


\begin{tabular}{|l|l|}
\hline \multicolumn{1}{|c|}{ Givón (1980) } & \multicolumn{1}{c|}{ Cristofaro (2003)/Noonan (1985) } \\
\hline Atitude epistêmica fraca & de Enunciação \\
\hline Atitude epistêmica forte & de Atitude Proposicional/de Conhecimento \\
\hline Atitude emotiva fraca & \\
\hline Atitude emotiva forte & somente Desiderativos \\
\hline Forte tentativa & somente de Manipulação \\
\hline Implicativos & Fasais e de Manipulação \\
\hline & Perceptivos \\
\hline & Modais \\
\hline
\end{tabular}

Quadro 2-3: Predicados encaixadores segundo Givón (1980) Cristofaro (2003)/Noonan (1985)

O exame da classificação de tipos de predicados matrizes proposta por Dik (1997b) mostra que ela dispõe das seguintes classes:

(a) predicados que encaixam um ato de fala (como say e ask)

(b) predicados que encaixam uma proposição:

(i) predicados de atitude proposicional (compreendem atitudes intelectuais, como believe e presume, e atitudes emocionais, como fear)

(ii) predicados de conhecimento (de aquisição, como learn, e de perda, como forget)

(iii) predicados de percepção mental (como see e hear)

(c) predicados que encaixam termos predicacionais:

(iv) predicados diretivos (como order e ask)

(v) predicados de manipulação (como force e cause)

(vi) predicados de volição (como want)

(vii) predicados de percepção direta (como see)

(viii) predicados fasais (como begin e stop)

Conforme mostra o Quadro 2-4, a proposta de Cristofaro (2003) é muito similar à de 
Dik (1997b), que, por seu lado, deve ter assumido a de Noonan (1985) como sua fonte principal. Comparando-as, entretanto, com a de Givón (1980), percebe-se que Dik acrescenta os predicados de percepção física e mental àquela, mas, similarmente, não leva em conta alguns tipos de predicados, como gostar e tentar, que se acham alistadas por Givón. Nesse aspecto, Cristofaro (2003) se alinha a Dik (1997b).

\begin{tabular}{|l|l|l|}
\hline \multicolumn{1}{|c|}{ Givón (1980) } & Cristofaro (2003)/Noonan (1985) & \multicolumn{1}{c|}{ Dik (1997b) } \\
\hline Atitude epistêmica fraca & de Enunciação & de Ato de fala \\
\hline Atitude epistêmica forte & $\begin{array}{l}\text { de Atitude Proposicional/de } \\
\text { Conhecimento }\end{array}$ & $\begin{array}{l}\text { de Atitude proposicional } \\
\text { (intelectuais)/de Conhecimento }\end{array}$ \\
\hline Atitude emotiva fraca & somente Desiderativos & $\begin{array}{l}\text { de Volição, de Atitude } \\
\text { proposicional (emocionais) }\end{array}$ \\
\hline Atitude emotiva forte & somente de Manipulação & $\begin{array}{l}\text { somente Diretivos de } \\
\text { Manipulação }\end{array}$ \\
\hline Forte tentativa & Fasais e de Manipulação & Fasais e deManipulação \\
\hline Implicativos & Perceptivos & de Percepção física \\
\hline & de Conhecimento & de Percepção mental \\
\hline & Modais & \multicolumn{1}{c|}{ de } \\
\hline
\end{tabular}

Quadro 2-4: Predicados encaixadores segundo Givón (1980), Cristofaro (2003)/Noonan (1985) e (Dik (1997b)

Dixon (2006) postula uma classificação própria de predicados encaixadores, subdividindo-os em duas categorias principais, que denomina predicados Primários e Secundários. Os Primários, que se identificam basicamente por terem como complemento um sintagma nominal ou um pronome, sãosubclassificados em Primários $A$ e $B$. Os do tipo $A$ são os que necessariamente tomam como complemento um sintagma nominal ou um pronome; os do tipo $B$ têm os mesmos complementos que os do tipo A, mas admitem, além deles, um complemento oracional. Os predicados Primários $B$, que se mostram relevantes para este trabalho, são os seguintes:

(i) de atenção (attention) (see, hear, notice, smell, show, recognize, discover, find) 
(ii) de pensamento (thinking) (think (of/about/over), consider, imagine, dream (of/about), assume, suppose, remember, forget, know, understand, believe, suspect)

(iii) de experiência psicológica (liking) (like, love, prefer, regret, fear, enjoy)

(iv) de enunciação (speaking) (say, inform, tell (one sense), report, describe, refer to, promise, threaten, order, command, ask, persuade, tell (one sense))

Além dos primários, todas as línguas têm um conjunto de predicados que, segundo o autor, convém chamar de 'conceitos secundários', uma vez que esse tipo sempre requer estar ligado a um outro verbo por não poder ser utilizado isoladamente. Os tipos Secundários A identificam predicados cujo conceito secundário está associado ao verbo com o qual se relaciona. Como Secundários A, Dixon (2006) considera os seguintes tipos:

(v) modais

(vi) de início (beginning-type): predicados como begin, start, continue, stop, cease, finish (vii) de tentativa (trying-type), tais como try e attempt

Os encaixadores denominados por Dixon (2006) Secundários $B$ são verbos transitivos que podem ou não dispor do mesmo sujeito:

(viii) want, wish (for), hope (for), intend, plan (for) e pretend

Os predicados Secundários $C$, por sua vez, identificam-se como classe pelo fato de terem sujeitos diferentes no complemento oracional ou, quando dispuserem de sujeitos correferenciais, pelo fato de omitirem a referência ao sujeito na completiva:

(ix) make, cause, force, let e help

O Quadro 2-5 estabelece uma comparação entre as propostas de classificação de Givón (1980), Noonan (1985)/Cristofaro (2003), Dik (1997b) e a de Dixon (2006): ${ }^{32}$

\footnotetext{
${ }^{32}$ Por sua natureza, os predicados encaixadores Secundários $B$ e $C$, foram denominados, no quadro, predicados de Expectativa/Volitivos e Manipulativos/Causativos, respectivamente.
} 


\begin{tabular}{|c|c|c|c|}
\hline Dixon (2006) & Givón (1980) & $\begin{array}{l}\text { Noonan (1985)/ } \\
\text { Cristofaro (2003) }\end{array}$ & Dik (1997b) \\
\hline $\begin{array}{l}\text { de Atenção } \\
\text { (Attention) }\end{array}$ & $\begin{array}{l}\text { Discover - Atitude } \\
\text { epistêmica forte }\end{array}$ & Perceptivos & $\begin{array}{l}\text { de Percepção física e } \\
\text { de Percepção Mental }\end{array}$ \\
\hline $\begin{array}{l}\text { de Pensamento } \\
\text { (Thinking) }\end{array}$ & Atitude epistêmica forte & $\begin{array}{l}\text { de Conhecimento/Atitude } \\
\text { proposicional }\end{array}$ & $\begin{array}{l}\text { de Atitude } \\
\text { proposicional } \\
\text { (intelectuais) /de } \\
\text { Conhecimento }\end{array}$ \\
\hline $\begin{array}{l}\text { de Experiência psicológica } \\
\text { (Liking) }\end{array}$ & Atitude emotiva forte & & $\begin{array}{l}\text { de Atitude } \\
\text { proposicional } \\
\text { (emocionais) }\end{array}$ \\
\hline $\begin{array}{l}\text { de Enunciação } \\
\text { (Speaking) }\end{array}$ & Atitude epistêmica fraca & de Enunciação & de Ato de fala \\
\hline $\begin{array}{l}\text { Modais } \\
\text { (Modal-type) }\end{array}$ & & Modais & \\
\hline $\begin{array}{l}\text { de Início } \\
\text { (Beginning-type) }\end{array}$ & Implicativos & Fasais & Fasais \\
\hline $\begin{array}{l}\text { de Tentativa } \\
\text { (Trying-type) }\end{array}$ & Try - Forte tentativa & & \\
\hline $\begin{array}{l}\text { de Expectativa/Volitivos } \\
\text { (Secondary B) }\end{array}$ & $\begin{array}{l}\text { Want - Atitude emotiva } \\
\text { forte/Forte tentativa }\end{array}$ & Desiderativos & de Volição \\
\hline $\begin{array}{l}\text { Manipulativo/Causativo } \\
\text { (Secondary } C \text { ) }\end{array}$ & Implicativos & de Manipulação & $\begin{array}{l}\text { Diretivos e de } \\
\text { Manipulação }\end{array}$ \\
\hline
\end{tabular}

Quadro 2-5: Comparação entre tipos de predicados encaixadores segundo Dixon (2006), Givón (1980), Cristofaro (2003)/Noonan (1985) e (Dik (1997b)

Numa primeira fase da pesquisa, a análise parcial da relação entre tipos de predicados e tipos de complementos baseou-se na proposta de classificação sugerida por Cristofaro (2003; cf. NOONAN, 1985), bem como na Tipologia de Ligação proposta por Givón (1980). O problema é que é necessário contar com uma proposta com o maior grau de abrangência possível para poder identificar todos os predicados encaixadores encontrados nos dados reais. Optei, portanto, não por uma única proposta, mas por uma classificação compósita, que favorecesse o grau máximo de exaustividade, mas que tivesse a classificação de Dixon (2006) como base. 
Embora tenha optado pela classificação de Dixon (2006), algumas ressalvas devem ser feitas em relação ao arranjo final de tipos de predicados encaixadores utilizados na análise (cf. Quadro 2-7). Essas ressalvas dizem respeito (i) à classificação dos encaixadores mandar e pedir; (ii) aos tipos de predicados encaixadores que, na classificação de Dixon (2006), fazem parte da classe de predicados de pensamento; e (iii) aos predicados modais.

Em algumas classificações de tipos de predicados, os encaixadores mandar e pedir são tratados como predicados de manipulação (cf. NOONAN, 1985; GIVÓN, 1991; CRISTOFARO, 2003; SOUSA, 2007; EGAN, 2008; GONÇALVES et al., 2008). Na classificação de Dixon (2006), no entanto, esses predicados são tratados como predicados de enunciação. A opção do autor talvez se justifique pelo fato de esse tipo de predicado requerer que uma oração encaixada ocupe o espaço de um ato de fala em situações de discurso direto.

Predicados encaixadores como mandar, além de descreverem a transferência de uma informação, expressam que X faz alguma coisa para levar Y a realizar um evento (cf. DIK, 1997b). ${ }^{33}$ Identificam, entretanto, um comportamento semântico diferente do de verbos como fazer, permitir, deixar ou obrigar. Esses predicados são caracteristicamente de manipulação, mas não veiculam a idéia de que o ato manipulativo ocorre por meio de um ato de fala. Justamente por esse comportamento híbrido, predicados como pedir e mandar se posicionam na fronteira entre a classe dos predicados de enunciação e a dos predicados de manipulação. ${ }^{34}$

Diferentemente do que propõe Dixon (2006) e com base em outras classificações, postulo que a função inicial desses predicados limítrofes é a de manipulação. Como se verá mais adiante, em termos de tipo de complemento selecionado, mandar e pedir têm um

\footnotetext{
${ }^{33}$ Na classificação de Dik (1997b), predicados como mandar, ordenar e pedir, que são denominados predicados diretivos, têm a mesma definição dos predicados de manipulação. A diferença está na possibilidade de haver a intervenção de um ato de fala, como ocorre com os predicados diretivos, ou não, como ocorre com os predicados de manipulação.

${ }^{34}$ Em muitos casos, os verbos dizer e falar, verbos prototípicos de enunciação, também podem ter uma carga 'manipulativa', como em eu disselfalei que você tem que sair imediatamente!, funcionando como uma ordem, equivalente a eu mandei/ordenei/pedi que você saísse imediatamente!.
} 
comportamento semântico e morfossintático que os aproxima muito mais dos predicados encaixadores de manipulação do que dos de enunciação.

Outro problema com a classificação de Dixon (2006), a despeito de sua abrangência, está no fato de muitos predicados de natureza semântica diferente estarem sob um mesmo rótulo, como ocorre com a classe de predicados de pensamento, que engloba predicados como saber, lembrar, esquecer achar, pensar e acreditar. Desse modo, optei por estabelecer uma divisão mais refinada na classe de predicados de pensamento nos seguintes termos: (a) predicados de atitude proposicional, como (2-6), e predicados de conhecimento, como (2-7):

(2-6) Eu acho que Leo se casou com Ana.

(2-7) Eu soube do casamento de Leo com Ana.

Outra classe de predicados que mistura predicados de diferente natureza semântica é a de predicados encaixadores de atenção. Dixon (2006) não faz distinção entre predicados que designam percepção mental e os que designam percepção visual. Como são complementos que têm comportamento diferenciado, como mostram os exemplos (2-8) e (2-9), requerendo diferentes tipos de completivas, separei a classe de predicados de atenção em duas subclasses: (i) predicados encaixadores de conhecimento, tal como aparece na proposta de Cristofaro (2003), e (ii) predicados encaixadores de percepção física.

\section{(2-8) Ana viu que Alfredo se casou.}

(2-9) Ana viu Alfredo se casar.

Uma última ressalva diz respeito à consideração dos modais como um tipo de predicado encaixador, como ocorre na classificação de Dixon (2006), bem como na de Noonan (1985) e na de Cristofaro (2003). De um ponto de vista tipológico, os modais podem ser verdadeiros encaixadores em algumas línguas, admitindo outros tipos de complementos além de orações não-finitas, fato que pode justificar a presença desse tipo de verbo na 
classificação de predicados encaixadores (cf. CRISTOFARO, 2003, NOONAN, 1985).

Noonan (1985) considera, inclusive, que os modais são excelentes candidatos à união lexical. São predicados que requerem exclusivamente complementos não-finitos, restritos à forma infinitiva impessoal, já que o complemento de predicados modais prototípicos, como poder e dever, é determinado tanto pela correferencialidade entre os participantes quanto pela conceitualização temporal de evento singular.

De acordo com Bastos et al. (2007), em português, a modalidade epistêmica e deôntica pode ser expressa por operadores modais como poder e dever, respectivamente. O domínio da modalidade pode ser distinto tendo em vista a perspectiva para qual é orientada. (2-10), por exemplo, descreve a existência de possibilidade de ocorrência do estado de coisas descrito na completiva, "sem que o falante tenha responsabilidade por esse julgamento" (HENGEVELD; MACKENZIE, 2008, p. 174) $;^{35}$ tem-se, nos termos da GDF, uma modalidade epistêmica orientada para o evento.

(2-10) Inf.: com certeza se ela estudar mais ela pode ter um conhecimento maior sobre tudo... (IBORUNA - AC 024: 416)

O uso de saber em (2-11), por sua vez, diz respeito à relação entre o participante e a realização potencial do estado de coisas; por isso, trata-se aqui de uma modalidade orientada para o participante.

(2-11) ...e:: ele foi pra minha sala... né com nove anos já sem saber ler sem saber escrever e ele na verdade é muito engraçado porque ele faz caras e bocas faz caretas (IBORUNA - AC 088: 092)

Construções nominalizadas não ocorrem com modais, ou, no mínimo, não são aceitáveis nesse contexto. O outro extremo também não ocorre sob o risco de tornar a sentença agramatical, isto é, os modais tomarem uma oração finita como complemento.

\footnotetext{
${ }^{35} \mathrm{Cf}$. o original: [...] without the Speaker taking responsibility for these judgments.
} 
(2-12)a. Os pais de Ana disseram que ela deve se casar com Leo.

*b. Os pais de Ana disseram que ela deve o casamento com Leo.

*c. Os pais de Ana disseram que ela deve que (ela) se case com Leo.

Em comparação a todos os outros tipos de predicados encaixadores, os modais são os únicos que restringem, em português, qualquer tipo de 'complemento' que não seja uma oração não-finita com infinitivo impessoal. Seria possível pensar, desse modo, que o predicado determina o tipo de complemento e que, tal como sustentam Noonan (1985) e Cristofaro (2003), identificam-se como predicados encaixadores de um ponto de vista transsistêmico. No entanto, o comportamento dos modais em relação aos outros tipos de predicados é um indício seguro de que, ao menos no português, eles atuam como verdadeiros auxiliares. São, assim, predicados que não 'encaixam' orações, como fazem os predicados elencados por Noonan (1985), Cristofaro (2003) e Dixon (2006). ${ }^{36}$

Hengeveld e Mackenzie (2008) tratam os verbos modais como uma classe de palavra gramatical, como pode ser observado no Quadro 2-6:

\begin{tabular}{|llll|}
\hline $\begin{array}{c}\text { Classe de palavras } \\
\text { lexicais }\end{array}$ & Exemplo & $\begin{array}{c}\text { Classe de palavras } \\
\text { gramaticais }\end{array}$ & Exemplo \\
\hline Verbo & exterminar & Verbo auxiliar & dever \\
Nome & ferradura & Pronome & eu, ele \\
Adjetivo & terrível & Proadjetivo & tal \\
Advérbio & para cima & Proadvérbio & então \\
Adposição & embaixo & Adposição gramatical & de, em \\
Conjunção & enquanto & Conjunção gramatical & porque \\
Partícula & uau & Partícula gramatical & justamente \\
\hline
\end{tabular}

Quadro 2-6: Correspondências entre classes de palavras lexicais e gramaticais (cf. HENGEVELD; MACKENZIE, 2008, p. 401)

\footnotetext{
${ }^{36}$ No Capítulo 5, na seção 5.3 .7 (p. 200), que trata dos predicados fasais, o caráter de auxiliaridade dos modais é retomado.
} 
O Quadro 2-6 permite fazer distinção entre classe de palavras lexicais, tal como os predicados arrolados no Quadro 2-7, e classes de palavras gramaticais, como os modais. É possível afirmar que, no português, os modais não atuam como verdadeiros predicados, por formarem perífrases modais que codificam um único estado de coisas. Em virtude desse comportamento de auxiliaridade típica, não farão parte do rol de predicados encaixadores considerados neste trabalho.

\begin{tabular}{|c|c|c|}
\hline Predicado encaixador & Característica $^{37}$ & Exemplos \\
\hline $\begin{array}{l}\text { de Enunciação } \\
\text { (Speaking) }\end{array}$ & $\begin{array}{l}\text { Descreve a transferência de uma informação do falante } \\
\text { para o ouvinte; o complemento desse tipo de predicado } \\
\text { representa a informação transferida (NOONAN, 1985). }\end{array}$ & $\begin{array}{l}\text { Ana disse que Leo saiu. } \\
\text { Leo contou que Ana viajou. }\end{array}$ \\
\hline $\begin{array}{l}\text { de Atitude proposicional } \\
\text { (Thinking) }\end{array}$ & $\begin{array}{l}\text { Especifica a atitude de uma pessoa em relação ao fato } \\
\text { possível designado pelo complemento; expressa uma } \\
\text { atitude em relação à verdade manifestada no } \\
\text { complemento (NOONAN, 1985; DIK, 1997b; } \\
\text { CRISTOFARO, 2003). }\end{array}$ & $\begin{array}{l}\text { Leo acha que Alfredo não } \\
\text { voltará. } \\
\text { Ana acredita que Leo não faltará. }\end{array}$ \\
\hline $\begin{array}{l}\text { de Conhecimento } \\
\text { (Thinking/Attention) }\end{array}$ & $\begin{array}{l}\text { Designa (o processo de) aquisição, posse, perda do fato } \\
\text { designado pelo complemento oracional (DIK, 1997b; } \\
\text { CRISTOFARO, 2003). }\end{array}$ & $\begin{array}{l}\text { Pedro sabe que Ana voltará. } \\
\text { Ana notou que Leo chegou. }\end{array}$ \\
\hline $\begin{array}{l}\text { de Percepção física } \\
\text { (Attention) }\end{array}$ & $\begin{array}{l}\text { Indica uma percepção imediata; o predicado encaixador } \\
\text { nomeia o modo sensorial pelo qual um sujeito percebe o } \\
\text { evento codificado no complemento (DIK, 1997; } \\
\text { NOONAN, 1985). }\end{array}$ & $\begin{array}{l}\text { Pedro viu seu dedo sangrar. } \\
\text { Ana ouviu Leo bater na porta. }\end{array}$ \\
\hline $\begin{array}{l}\text { de Manipulação } \\
\text { (Secondary C) }\end{array}$ & $\begin{array}{l}\text { Indica que X faz alguma coisa (compelindo, autorizando, } \\
\text { impedindo) para que Y realize o estado de coisas descrito } \\
\text { no complemento oracional (DIK, 1997b; GONÇALVES } \\
\text { et al., 2008). }\end{array}$ & $\begin{array}{l}\text { Pedro mandou Leo sair. } \\
\text { Pedro pediu que Leo saísse. }\end{array}$ \\
\hline $\begin{array}{l}\text { de Volição } \\
\text { (Secondary B) }\end{array}$ & $\begin{array}{l}\text { Descreve o desejo do participante da oração matriz de } \\
\text { que o evento no complemento oracional se realize ou } \\
\text { deixe de se realizar (NOONAN, 1985; CRISTOFARO, } \\
\text { 2003). }\end{array}$ & $\begin{array}{l}\text { Ana quer morar em Cuba. } \\
\text { Leo deseja que Ana consiga } \\
\text { morar em Cuba. }\end{array}$ \\
\hline $\begin{array}{l}\text { Fasais } \\
\text { (Beginning-type) }\end{array}$ & $\begin{array}{l}\text { Indica a fase de desenvolvimento de uma ação, estado } \\
\text { (começo, continuação e fim) descrito no complemento } \\
\text { oracional (NOONAN, 1985, CRISTOFARO, 2003). }\end{array}$ & $\begin{array}{l}\text { Alfredo parou de fumar. } \\
\text { Leo começou a construção de } \\
\text { sua casa. }\end{array}$ \\
\hline $\begin{array}{l}\text { de Experiência psicológica } \\
\text { (Liking) }\end{array}$ & $\begin{array}{l}\text { Expressa uma avaliação subjetivo-emocional do falante } \\
\text { em relação ao conteúdo expresso pelo complemento } \\
\text { oracional (NEVES, 2002; GONÇALVES et al., 2008). }\end{array}$ & $\begin{array}{l}\text { Ana odeia que mexam em suas } \\
\text { coisas. } \\
\text { Leo gosta de dormir cedo. }\end{array}$ \\
\hline $\begin{array}{l}\text { de Tentativa } \\
\text { (Trying-type) }\end{array}$ & $\begin{array}{l}\text { Indica que o participante do estado de coisas principal } \\
\text { emprega meios para realizar/ conseguir que o estado de } \\
\text { coisas descrito no complemento oracional ocorra. }\end{array}$ & Leo tentou se casar com Ana. \\
\hline
\end{tabular}

Quadro 2-7: Tipos de predicados encaixadores considerados para análise

\footnotetext{
${ }^{37}$ Apesar de haver adotado, em maior parte, a proposta de classificação de Dixon (2006), as definições semânticas dos predicados encaixadores são de outros autores (NOONAN, 1985; DIK, 1997b; NEVES, 2002; CRISTOFARO, 2003; GONÇALVES et al., 2008), já que Dixon se resume à classificação, não vendo relevância em defini-las.
} 
Observada a relação que se estabelece entre o predicado encaixador de complemento e o tipo de completiva requerido, bem como a classificação de tipos de predicados encaixadores, a seção a seguir volta-se para os tipos de completivas, distribuídas numa escala entre completamente verbais e completamente nominais.

\subsection{A gradação entre construções encaixadas verbais e nominais}

\subsubsection{Tipos de orações completivas: propriedades verbais e nominais}

No processo de subordinação completiva, a presença de propriedades nominais está vinculada à perda de propriedades verbais. Essa correlação aparece refletida na Hierarquia da Desverbalização, de Croft (1991), nos dados discutidos por Comrie (1976) e KoptjevskajaTamm (1993), no continuum de dessentencialização de orações subordinadas proposto por Lehmann (1988) e na Hierarquia de Frequência proposta por Cristofaro (2003).

A literatura linguística dispõe de modelos cognitivos e discursivos voltados para a distinção entre nomes e verbos (cf. HOPPER; THOMPSON, 1984; LANGACKER, 1987a, 1987b, 1991; e CROFT, 1991). Esses modelos também procuram discutir por que razão formas verbais perdem suas propriedades e dispõem de propriedades nominais em alguns contextos, particularmente no que diz respeito a orações subordinadas.

Givón (1979) e Hopper e Thompson (1984) sustentam a posição de que é possível predizer, em termos universais, que certas percepções de entidades prototipicamente próximas de uma "coisa" sejam gramaticalmente codificadas como nome, enquanto percepções prototípicas de ações ou eventos sejam gramaticalmente codificadas como verbos.

Hopper e Thompson (1984) definem a distinção entre nomes e verbos em termos de função no discurso. Nomes são prototipicamente usados no discurso para se referirem a participantes manipuláveis, enquanto verbos são prototipicamente usados para se referirem a eventos. Se um nome ou um verbo 'falha' em cumprir sua função prototípica no discurso, 
deixará de apresentar a marca morfossintática característica de sua categoria de nome ou de verbo e, possivelmente, apresentará características da categoria oposta. Nessa perspectiva, o motivo pelo qual formas verbais que codificam eventos dependentes perdem suas propriedades de verbo (e dispõem de propriedades típicas de nomes) é que essas formas verbais deixam de cumprir sua função prototípica.

Langacker (1987a, 1987b, 1991) faz a distinção entre verbos e nomes em termos cognitivos. Nomes designam coisas, enquanto verbos designam processos. Croft (1991) distingue verbos e nomes em termos das características semânticas de bases lexicais e das funções pragmáticas que essas bases desempenham em sua manifestação em determinada posição na estrutura oracional. Bases lexicais podem designar objetos, que são apropriados para a função pragmática de referência, ou ações, que são apropriadas para a função pragmática de predicação. Segundo o autor, as relações de subordinação envolvem correlações não-prototípicas de classe semântica e função pragmática. Relações de complementação envolvem o uso de palavras que denotam ação para designar referência.

A distinção de nome e verbo não está imune à falta de comensurabilidade entre as diferentes línguas no que diz respeito à percepção das categorias gramaticais. Em termos universais, nomes correspondem a percepções 'prototípicas' de entidades próximas a coisas, enquanto verbos são percepções prototípicas de ações ou eventos.

As classes de nomes e verbos têm correlatos semânticos muito próximos das entidades percebidas no mundo real. Para nomes, a entidade é algo como 'coisa' ou 'objeto' (ou 'estabilidade temporal', como considera Givón (1979)). Verbos, em contraste, são prototipicamente entidades de ação ou evento; eles são usados para simbolizar a percepção que carece de estabilidade temporal. Essa dualidade perceptual se reflete na tendência universal de associar entidades temporalmente estáveis a nomes e entidades não temporalmente estáveis a classe gramatical de verbos. 
A relação entre um predicado encaixador e a oração completiva que esse predicado admite pode envolver a perda de propriedades verbais e a presença de propriedades nominais. Verbos dispõem de propriedades que os caracterizam, como tempo, aspecto, modo (TAM) e distinção de pessoa. Assim, o fenômeno da perda de categorias TAM e de distinção de pessoa pode ser vista como a perda de propriedades típicas das formas verbais. Nomes podem ser caracterizados por sua função na oração, usualmente indicada por meio da marcação de caso ou adposições. Desse modo, fenômenos como a presença de marcação de caso ou adposições em verbos e a codificação do argumento do verbo como possuidor podem ser vistos como a evidência da presença de propriedades nominais nas formas verbais. ${ }^{38}$

A preservação ou a perda de propriedades verbais, bem como a presença de propriedades nominais é tratada por Koptjevskaja-Tamm (1993) em termos de equivalência (balancing) e rebaixamento (deranking). ${ }^{39}$ 'Construções equivalentes' (balanced constructions) devem ser entendidas como aquelas em que o predicado, tanto da oração matriz quanto da subordinada, permanece estruturalmente no mesmo nível; já nas 'construções rebaixadas' (deranked constructions), um predicado perde suas propriedades verbais, isto é, a sua forma verbal assinala seu status de subordinado em relação à outra oração, o que, contudo, não impede o uso de outros marcadores de subordinação. (KOPTJEVSKAJA-TAMM, 1993).

Koptjevskaja-Tamm (1993) assinala que, em termos de subordinação completiva, as línguas podem dispor de orações equivalentes e rebaixadas ('línguas de complemento equivalente' - complement-balancing languages) e outras em que se deve obrigatoriamente

\footnotetext{
${ }^{38}$ Segundo Noonan (1985), diversos fatores podem afetar a semântica potencial de um determinado tipo de complemento, dentre eles o status gramatical do predicado encaixado - verbo, nome ou adjetivo. Noonan afirma que predicados-complementos são, na grande maioria dos casos, codificados como verbos (como, por exemplo, as orações finitas e os complementos infinitivos), caracterizando-se, assim, como um tipo de complementação não-marcada. Há línguas em que essa é a única possibilidade de codificar o predicado. Sendo a forma verbal o tipo não-marcado, os tipos marcados ficam, então, a cargo das predicações nominalizadas (como nominalizações) e adjetivais (particípios), observando-se que essas duas formas, na maioria das vezes, coexistem em sistemas de complemento com predicados codificados como verbos.

${ }^{39}$ As estratégias de equivalência (balancing) e rebaixamento (deranking) aparecem, originalmente, em Stassen (1985).
} 
rebaixar o predicado para se obter um complemento nominalizado ('línguas de complemento rebaixado' - complement-deranking languages). O chinês, por exemplo, é uma língua que, no processo de subordinação, vale-se somente de construções completivas equivalentes e, por isso, é considerada uma língua estritamente do tipo complement-balancing.

Enquanto essa classificação opositiva é aplicável a línguas num enfoque tipológico, é possível contar com sistemas linguísticos que não apenas dispõem dos dois tipos de complementos, como também de uma escala em que os tipos constituem dois extremos. Os complementos em português podem ocorrer como uma completiva finita ou como uma oração não-finita com infinitivo ou com nominalização.

Embora haja, de um ponto de vista tipológico, uma grande variedade de tipos de completivas, é possível discernir padrões recorrentes de construções encaixadas. Dik (1997b) fornece uma taxionomia com validade transsistêmica para as construções encaixadas, que pode ser vista na Figura 2-2.

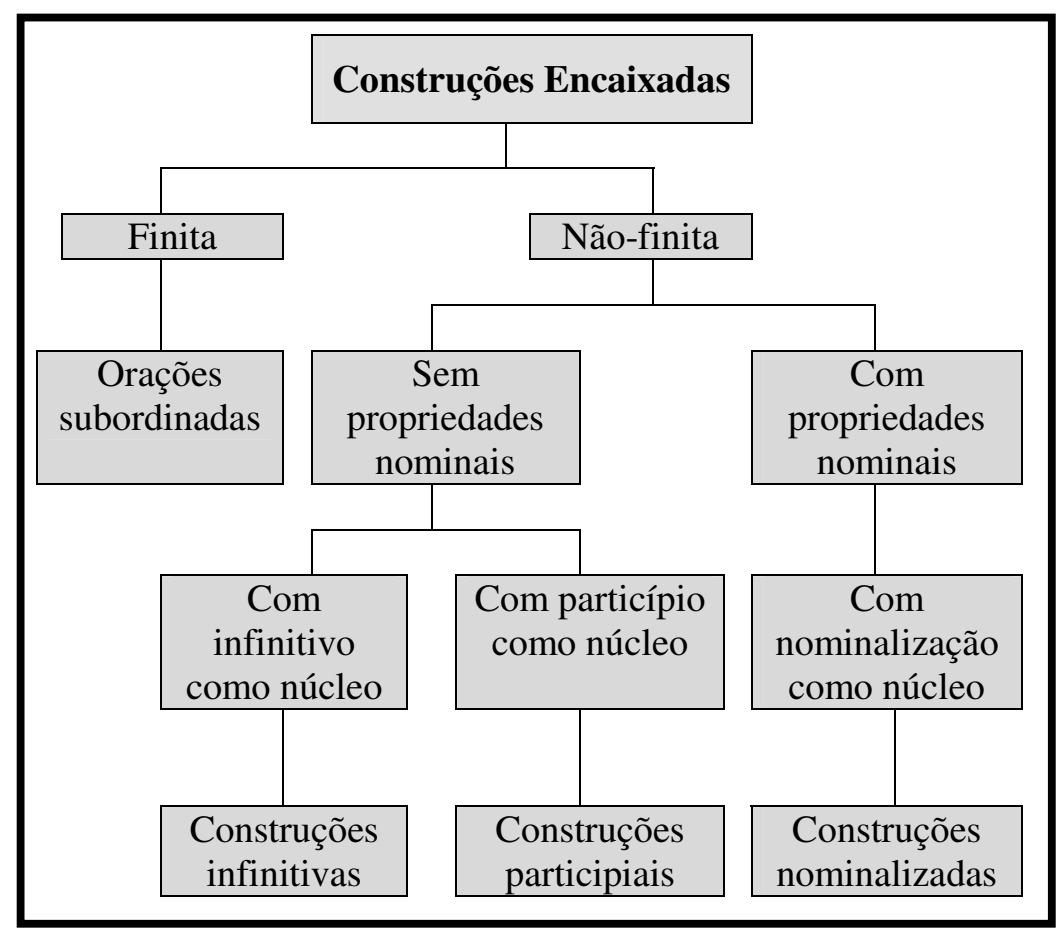

Figura 2-2: Tipos de construções encaixadas (cf. DIK, 1997b, p. 142; adaptado por CAMACHO, 2009, p. 205) 
À taxionomia de Dik (1997b), Camacho (2009) adiciona a nominalização como "construção nominalizada", tal como ocorre com as construções sem propriedades nominais com infinitivo e com particípio como núcleo. Segundo Camacho (2009, p. 116), embora o único traço que as construções infinitivas e participiais (gerúndios e particípios) têm em comum com as nominalizações seja a possibilidade de constituir o núcleo da construção encaixada, "há outro traço relevante, compartilhado por todos os tipos de construções encaixadas não-finitas, que é a possibilidade de realização como predicação fechada ou aberta, conforme a natureza especificada ou não-especificada da estrutura argumental de que dispõem". ${ }^{40}$ Dik (1997b), no entanto, atribui esse traço somente a construções infinitivas e participiais, deixando de fora as nominalizações, embora as inclua entre as predicações encaixadas que têm propriedades nominais. Camacho (2009) defende, então, a ideia de que a noção de predicação aberta é crucial para se entender a ausência de argumentos nas nominalizações e que, portanto, essa propriedade deve ser atribuída às nominalizações.

A primeira distinção que Noonan (1985) faz em relação aos tipos de complemento é entre os complementos sentenciais, ou orações finitas, e os outros tipos, as orações não-finitas (formas infinitivas e nominalizações), conforme disposto no Quadro 2-8. Segundo o autor, complemento do tipo sentencial é aquele que, sem seu complementizador, tem a mesma codificação sintática que a da oração principal. Em complementos sentenciais, o predicado tem a mesma relação sintática com seu sujeito e seus outros argumentos que tem a oração principal: ele permanece sintática e morfologicamente como verbo, mas não exclui a possibilidade de sua formulação diferir em certos aspectos da sintaxe da oração principal. ${ }^{41}$

\footnotetext{
${ }^{40}$ Predicações abertas e fechadas se diferem no que diz respeito à natureza especificada ou não especificada da estrutura argumental. Uma predicação aberta é aquela em que todas as posições, com exceção da ocupada pelo próprio termo, são preenchidas por estruturas de termo; ela funciona como um restritor dos valores possíveis que o termo pode ter (cf. DIK, 1997a).

${ }^{41}$ Essa distinção feita por Noonan (1985) não corresponde à oposição entre orações equivalentes e rebaixadas (justamente porque complementos sentenciais podem ser tanto equivalentes quanto rebaixados), mas coincide com a distinção entre orações finitas e não-finitas.
} 


\begin{tabular}{|c|c|c|c|c|}
\hline $\begin{array}{c}\text { Tipo de } \\
\text { complemento }\end{array}$ & $\begin{array}{l}\text { Categoria do } \\
\text { predicado }\end{array}$ & $\begin{array}{c}\text { Relação sintática - sujeito e } \\
\text { predicado }\end{array}$ & $\begin{array}{l}\text { Escala de } \\
\text { categorias } \\
\text { flexionais }\end{array}$ & $\begin{array}{c}\text { Outras } \\
\text { características }\end{array}$ \\
\hline Indicativo & verbo & a mesma da oração principal & $\begin{array}{l}\text { a mesma da oração } \\
\text { principal }\end{array}$ & $\begin{array}{l}\text { forma do } \\
\text { complemento- } \\
\text { sentença idêntica à } \\
\text { oração principal } \\
\text { declarativa }\end{array}$ \\
\hline Subjuntivo & verbo & a mesma da oração principal & $\begin{array}{l}\text { tipicamente } \\
\text { reduzida }^{42}\end{array}$ & $\begin{array}{l}\text { forma da sentença- } \\
\text { complemento que } \\
\text { difere da oração } \\
\text { principal declarativa }\end{array}$ \\
\hline Paratático & verbo & $\begin{array}{l}\text { o predicado pode concordar } \\
\text { com o sujeito, mas não } \\
\text { forma constituinte com ele }\end{array}$ & $\begin{array}{l}\text { a mesma do } \\
\text { Indicativo }\end{array}$ & $\begin{array}{l}\text { interpretada como } \\
\text { asserção separada; } \\
\text { não toma } \\
\text { complementizador }\end{array}$ \\
\hline Infinitivo & verbo & $\begin{array}{l}\text { o predicado não pode formar } \\
\text { constituinte com o sujeito }\end{array}$ & $\begin{array}{l}\text { reduzida; não pode } \\
\text { ter a concordância } \\
\text { sujeito - verbo }\end{array}$ & $\begin{array}{l}\text { mesma relação com } \\
\text { o objeto que tem o } \\
\text { tipo Indicativo }\end{array}$ \\
\hline Nominalização & nome & $\begin{array}{l}\text { relação associativa entre } \\
\text { sujeito e predicado }\end{array}$ & $\begin{array}{l}\text { reduzida; pode } \\
\text { tomar categorias } \\
\text { nominais, tais como } \\
\text { caso e número }\end{array}$ & $\begin{array}{l}\text { estrutura interna de } \\
\mathrm{SN} \text {; gradação } \\
\text { frequente entre } \\
\text { nominalizações e } \\
\text { infinitivos }\end{array}$ \\
\hline Particípio & adjetivo/advérbio & $\begin{array}{l}\text { o sujeito é o núcleo; o resto } \\
\text { da predicação é modificado }\end{array}$ & $\begin{array}{l}\text { reduzida; pode } \\
\text { tomar flexões } \\
\text { adjetivais quando } \\
\text { concordando com o } \\
\text { sujeito }\end{array}$ & $\begin{array}{l}\text { sintaticamente, pode } \\
\text { obedecer os } \\
\text { princípios que } \\
\text { governam os } \\
\text { adjetivos }\end{array}$ \\
\hline
\end{tabular}

Quadro 2-8: Tipos de complementos (NOONAN, 1985, p. 65)

As orações finitas têm as propriedades de uma oração principal, a partir de mecanismos que assinalam seu estatuto de construção subordinada (como, por exemplo, um subordinador; uma ordenação especial do constituinte subordinado (DIK, 1997b)).

Complementos reduzidos estão tipicamente associados a predicados cujo complemento tenha referência temporal dependente ou determinada. Em outras palavras, a referência temporal desses complementos é uma consequência necessária do significado do predicado encaixador. Complementos infinitivos, por exemplo, são restritos a contextos de referência temporal determinada, ocorrendo com predicados que expressam comando, pedido, intenção, desejo etc. (mesmo assim, em muitos casos, é necessário observar a

\footnotetext{
${ }^{42}$ Ao tratar do subjuntivo como tendo categoria flexional reduzida, Noonan (1985) faz referência a línguas como o russo, em que, em relação ao indicativo, o subjuntivo tende a ter menos possibilidades de flexão, e o grego clássico, em que o subjuntivo perde distinções de tempo e marca somente distinções aspectuais.

${ }^{43}$ Para o português, isso parece não se aplicar, já que dispõe de infinitivo pessoal, isto é, flexionado, e de infinitivo impessoal.
} 
correferencialidade de participantes para a ocorrência de complementos infinitivos). De acordo com Koptjevskaja-Tamm (1993), complementos reduzidos podem aparecer como nomes verbais, particípios ou gerúndios e podem ser caracterizados pela adição de algum marcador específico ou pela aplicação de um modo dependente especial. As formas verbais não-finitas constituem um tipo de elemento reduzido.

Construções não-finitas com infinitivo são aquelas construídas em torno de um predicado infinitivo. ${ }^{44}$ Essas construções apresentam menos distinções de tempo, modo e aspecto do que os verbos finitos (tipicamente, predicado que aparece no infinitivo é marcado somente para as distinções aspectuais), não podem se constituir como verbo principal de uma oração independente e não apresentam concordância com os termos com que ocorrem (exceto, no português, com o infinitivo pessoal); são, entretanto, uma forma verbal, pois não apresenta propriedades bem definidas de adjetivos ou nomes (cf. DIK, 1997b).

Complementos nominalizados são predicações com a estrutura interna de um sintagma nominal. Esse tipo de complemento varia consideravelmente quanto às categorias verbais que ele pode preservar, oscilando entre os complementos nominalizados que podem expressar poucas categorias verbais e os que retêm as características encontradas em orações principais. Segundo Noonan (1985), no paradigma verbal, é mais provável que a forma de uma nominalização seja mais idiossincrática do que as construções no infinitivo, que têm uma relação regular com o paradigma verbal finito.

As orações finitas se opõem aos vários tipos de orações completivas não-finitas: formas verbais não-finitas são formas verbais dependentes por excelência, justamente porque esse tipo de construção não pode nunca atuar como predicado de orações independentes. $\mathrm{O}$ fato de a oração não-finita ser a forma verbal dependente por excelência não significa, entretanto, que toda forma verbal dependente seja necessariamente uma oração não-finita. Há,

\footnotetext{
${ }^{44}$ Embora as construções infinitivas e participiais sejam consideradas construções não-finitas (cf. NOONAN, 1985; KOPTJEVSKAJA-TAMM, 1993; DIK, 1997b), interessam, neste trabalho, somente as orações não-finitas com infinitivo.
} 
assim, línguas de complemento não-sentencial em que orações independentes e complementos são estruturalmente similares, diferindo somente em seu modo verbal independente e dependente, respectivamente.

De acordo com Koptjevskaja-Tamm (1993), em línguas com construções completivas do tipo equivalente, as construções de nominais de ação competem com orações nominais finitas - e, talvez, com algum outro tipo de oração nominal - por significados e funções. ${ }^{45} \mathrm{O}$ inglês e o russo, por exemplo, têm construções nominais de ação capazes de expressar eventos, fatos e proposições, se as duas últimas categorias são normalmente denotadas por orações nominais finitas. Contudo, saber a categoria semântica de um complemento não é suficiente para determinar o seu tipo sintático. Muitas línguas têm vários tipos de nominais de ação com significados e funções diferentes (línguas de complemento dessentencializado); às vezes, esses nominais de ação permitem o mesmo tipo de nominalização; noutras vezes, comportam-se de forma diferente, dependendo do seu significado exato.

\subsubsection{Os graus de sentencialidade e de nominalidade}

Entre os diversos tipos de operações transcategoriais, o mais estudado é a nominalização, como se vê nos trabalhos de Comrie e Thompson (1985), Noonan (1985), Lehmann (1988), Dik (1985; 1997b), Croft (1991), Kopjevskaja-Tamm (1993), Cristofaro (2003) e Malchukov (2004). Embora, na visão tradicional, a nominalização envolva tanto a aquisição de propriedades nominais quanto a perda de propriedades verbais, de acordo com Malchukov (2004), tem-se reconhecido mais recentemente que as operações transcategoriais, tais como a nominalização, envolvem tanto descategorização quanto recategorização.

\footnotetext{
${ }^{45}$ Os nominais de ação são o que Koptjevskaja-Tamm (1993) chama de nominalização lexical, que se difere de nominalização oracional. Segundo a autora, em nominais de ação, o processo de nominalização envolve o núcleo, provocando uma alteração do seu estatuto categorial em comparação às orações independentes. Nominalizações oracionais, por sua vez, são aquelas cujo traço característico é a ausência de evidência em favor de se analisar o núcleo desse tipo de construção como um nome lexical; isto é, o verbo em uma oração desse tipo geralmente não tem características nominais, mas tem, muitas vezes, características verbais, como pessoa e número, embora possa faltar marcação aspectual e temporal (cf. KOPTJEVSKAJA-TAMM, 1993).
} 
O termo descategorização, introduzido inicialmente por Hopper e Thompson (1984), indica que verbos e nomes tendem a perder algumas das propriedades morfossintáticas associadas com suas funções primárias de relatar eventos e referir-se a termos, respectivamente. Assim, um verbo usado como expressão referencial adquire propriedades nominais, como caso, determinação, modificação etc., e é por isso que o termo "nominalização" reúne propriedades relacionadas tanto ao processo de desverbalização quanto ao de substantivização (cf. MALCHUKOV, 2004).

Em seu funcionamento, os processos de recategorização $(\mathrm{R})$ e descategorização (D) preservam uma independência relativa: como demonstram Hopper e Thompson (1984), do mesmo modo que descategorização não acarreta necessariamente recategorização, também recategorização não acarreta necessariamente descategorização. Usando exemplos do inglês, Malchukov (2004) menciona quatro possibilidades na tipologia das construções completivas encaixadas, contidas em (2-12):

(2-12)a. [-D/-R] complementos sentenciais (I know that he comes)

b. [+D/-R] infinitivos (I want him to come early)

c. $[-\mathrm{D} /+\mathrm{R}]$ nominalização oracional (I disapprove of his driving the car so carelessly)

d. $\quad[+\mathrm{D} /+\mathrm{R}]$ nominalizações (I didn't see $\underline{\text { John's arrival) }}$

(Adaptado de MALCHUKOV, 2004, p. 57)

A construção (2-12a) se refere a um complemento sentencial: embora ocorra numa posição de objeto (sintagma nominal), ela retém a estrutura de uma sentença e raramente adquire traços nominais. No caso (2-12b), os infinitivos retêm a sintaxe interna de um sintagma verbal em relação a alguns traços semânticos, como possibilidade de argumento, aspecto e voz, mas não podem assumir outras propriedades tipicamente verbais, como tempo e modo e, no caso citado do inglês, concordância e combinação com um sujeito nominativo da forma sentencial. O caso (2-12c) combina, por seu lado, traços nominais e verbais: é capaz de receber objeto, enquanto o sujeito é expresso como um sintagma preposicionado, isto é, na 
forma gramatical típica de possuidor. Finalmente, em (2-12d), o verbo é completamente assimilado a um nome: assume todas as flexões nominais e raramente preserva traços gramaticais de verbo.

Enquanto complementos sentenciais e nominalizações, representando os pólos opostos na escala, são codificados por classes lexicais mais ou menos universais, como verbo e nome respectivamente, o estatuto categorial das classes intermediárias difere muito de uma língua para outra. Os exemplos do inglês servem apenas para ilustrar as construções encaixadas possíveis e, por isso, não podem ser tomados como universais, principalmente em função da diversidade tipológica das línguas. Assim, a gramática do português, por exemplo, não licencia a ocorrência de (2-12c), e só permite construções não-finitas com predicados volitivos (2-12b), se houver correferencialidade entre os participantes da matriz e da encaixada. Nesse aspecto, difere da gramática do inglês, que, como se vê em (2-12b), licencia a forma não-finita mesmo com identidade entre objeto da matriz e sujeito manifesto como anáfora zero na encaixada.

A partir da categoria mista das nominalizações, Malchukov (2004) afirma que, com base em hierarquias de categorias verbal e nominal, podem ser feitas predições significativas em relação aos processos que envolvem esse tipo de construção. Considerando-se essas hierarquias, o autor sugere que as categorias mais externas (camadas) são mais prontamente afetadas pelas operações transcategoriais do que as camadas mais internas. Isso significa que categorias externas são mais prontamente adquiridas/perdidas no processo de mudança categorial. Essa generalização tem uma motivação funcional: operadores externos refletem a função sintática e/ou pragmática de um item lexical muito mais do que operadores internos.

As hierarquias de categorias verbal e nominal são relevantes para restringir os diferentes tipos de possíveis operações transcategoriais, tais como nominalização. A mudança verbo - nominalização (desverbalização) deriva da perda progressiva na escala da 
categorialidade verbal: perdem-se traços como força ilocucionária, modo e concordância (sujeito), usados para assinalar a função da forma verbal. Na escala de desverbalização (MALCHUKOV, 2004), a nominalização só perde a condição de referência a um estado de coisas quando se transforma realmente num substantivo de primeira ordem, como detectável nas nominalizações de resultado como construções em os haitianos viram todas as construções ruírem. As categorias mais externas e respectivas camadas são mais prontamente afetadas pelas operações transcategoriais do que as mais internas. Desse modo, a valência é, na visão do autor, a camada semanticamente mais próxima do lexema verbal e, portanto, mais preservada do que as demais categorias. ${ }^{46}$

No estágio inicial da escala da desverbalização proposto por Malchukov (2004), todas as categorias verbais estão mantidas nas formas não-finitas. A desverbalização completa envolve a perda de todas as categorias verbais, incluindo a valência. Com base nos processos complementares de desverbalização e de nominalização e considerando ainda não haver restrição na integração das duas hierarquias categoriais (nome e verbo), Malchukov propõe o Modelo Escalar Generalizado (Generalized Scale Mode) ${ }^{47}$ :

(2-13) Modelo Escalar Generalizado

[[[[[N]CL]NUM]POS]DET]CAS

nominalização $\quad<$ desverbalização

(Adaptado de MALCHUKOV, 2004, p .66)

Mackenzie (1996) distingue quatro graus de nominalizações, ordenadas em uma hierarquia entre 'completamente verbal' e 'completamente nominal'. Nominalizações de grau 0 são construções plenamente verbais: a oração matriz tem como complemento uma oração

\footnotetext{
${ }^{46}$ Camacho (2009) serve-se dessa resistência da propriedade valencial das nominalizações para encaixá-las num ponto intermediário entre os membros prototípicos de nomes e de verbos.

${ }^{47}$ No polo da nominalização, a forma adquire progressivamente caso (CAS), determinação (DET), posse (POS), número (NUM), classificador (CL); no polo da desverbalização, a forma perde progressivamente força ilocucionária (FI), concordância (CONC), modo (MOD), tempo (TEMP), aspecto (ASP) e valência (VAL).
} 
finita (como em John saw that Peter signed the cheque); nas nominalizações de grau 1, ocorre a desverbalização parcial, isto é, perdem-se diferentes propriedades verbais - o verbo encaixado é caracterizado como dependente, não-principal e não-finito (como em John saw Peter signing the cheque); nas nominalizações de grau 2, a construção encaixada é marcada por preposições, que são indicadoras características de termos nominais (como em John approved of Peter signing the cheque); nas nominalizações de grau 3, tem-se a presença opcional do possuidor ou algum outro termo dependente na expressão referida, presença opcional ou requerida de operadores de termos, isto é, artigos, demonstrativos etc. (como em John deplored Peter's signing of the cheque); as nominalizações de grau 4, por fim, caracterizam-se pelo alto grau de nominalidade, adquirindo as propriedades características de termos nominais (como em John disapproved of Peter's repeated denials of the charges).

Toda nominalização se caracteriza por dispor de ajustes que a tornam mais ou menos nominal, de modo que é possível obter-se uma escala de construções encaixadas que podem variar entre o polo das mais verbais para o polo das mais nominais. Para caracterizar a escala gradativa de construções verbais e nominais, Mackenzie (1996) fornece construções nas quais há um 'deslizamento' nominal que leva uma expressão completamente verbal para uma construção completamente nominal, por meio de três tipos de gerúndio com um caráter parcialmente verbal e parcialmente nominal:

\section{(2-14)a. I regretted that John refused the offer \\ b. I regretted John refusing the offer. \\ c. I regretted John's refusing the offer \\ d. I regretted John's refusing of the offer. \\ e. I regretted John's refusal of the offer}

(Adaptado de Mackenzie, 1996, p. 330)

Segundo Mackenzie (1996), em (2-11a-b), ambos os argumentos de refuse são 
obrigatórios; em (2-14c), somente o paciente é gramaticalmente requerido e, em (2-14d-e), nenhum argumento é requerido. Em (2-14a), o verbo tem propriedades totais de finitude, tempo e aspecto, enquanto em (2-14b-c) somente a oposição de tempo entre passado (having refused) e não-especificado (refusing) é possível; em (2-14d-e) não pode haver nenhuma marca de categorias verbais. Quanto a marcadores de nominalidade, eles estão completamente ausentes em (2-14a); (2-14b) pode ser associado com uma preposição; (2-14c) aceita um demonstrativo (that refusing the offer of John's); (2-14d) admite artigo definido (the refusing of the offer) e adjetivo; (2-14e), finalmente, mostra todas as características de um sintagma nominal. Há, assim, uma clara evidência de transição gradual entre construções completamente verbais e completamente nominais.

A hierarquia entre 'completamente verbal' e 'completamente nominal' proposta por Mackenzie (2006) pode ter uma atuação muito relevante, na tipologia linguística, na forma de uma hierarquia implicacional contida em (2-15).

(2-15) nominalidade (> operadores) $>$ possuidor/dependente $>$ marcas de função $>$ desverbalização

Assim, línguas que dispõem dos tipos sentenciais de grau n também dispõem dos tipos de grau n - 1. Em sua amostra, Mackenzie (1996) constatou que todas as línguas têm, ao menos, algum tipo de nominalização, e que as nominalizações de grau 4 são especialmente encontradas em línguas de posposição, como o português.

No tocante à gradação verbal/nominal do português, talvez o mais próximo do gerúndio do inglês seja o infinitivo, de modo tal que os casos em (2-14) poderiam ter correspondências gramaticalmente viáveis nas sentenças de (2-16).

(2-16)a. Eu lamentei que João tenha recusado a oferta.

b. Eu lamentei João ter recusado a oferta.

c.? Eu lamentei o recusar da oferta por João. 


\section{d. Eu lamentei a recusa da oferta por João.}

Em (2-16a), como em (2-14a), o verbo tem propriedades de finitude, tempo e aspecto e não há marcas de nominalidade (como há em (2-14c-d)). Já (2-16d), tal como (2-14e), mostra todas as características de um sintagma nominal. ${ }^{48}$

Essa escala de possibilidades, apresentada por Mackenzie (1996), parece relevante para tratar da descategorização de orações sob a ótica da gramaticalização, segundo Hopper (1991, 1996) e Hopper e Traugott (1993). Há um processo de ‘descategorização’ com perda gradativa de estatuto oracional, isto é, o verbo da oração finita 'perde' as marcas que a caracterizam, assumindo atributos de nome, no caso, adquirindo marcas de nominalidade, principalmente nas nominalizações de grau 4:

(2-17) Oração finita > oração não-finita com infinitivo > nominalização

Pode-se dizer, então, que a nominalização é o grau máximo de integração formal no processo de complementação sugerido pela hierarquia em (2-17), já que é o que mais se aproxima de um sintagma nominal na função de objeto.

Tendo em vista o grande número de propriedades verbais e nominais, o resultado do processo de nominalização envolve consideráveis ajustes formais. A questão que fica é se há uma ordem na perda (a partir da oração finita) e aquisição (considerando-se uma nominalização de grau 4) de características na produção de uma nominalização prototípica, isto é, com alto grau de nominalidade.

Ressalta-se, por fim, que quanto mais encaixada é uma construção, mais gramatical é o seu estatuto. A parataxe caracteriza-se, assim, pela relativa independência e integração mínima entre as orações; a hipotaxe, pela relativa interdependência e por um grau intermediário de integração; e a subordinação, finalmente, por total dependência e integração

\footnotetext{
${ }^{48}$ É necessário observar que o uso do subjuntivo, em (2-16a), formalmente ausente da morfossintaxe do inglês, fornece ao português um grau ainda maior de dependência oracional do que ao inglês.
} 
máxima entre as orações. Como já afirmado, a nominalização é o grau máximo de integração formal. A alta integração da oração subordinada com a oração principal correlaciona-se com a sua dessentencialização. Construções subordinadas nominalizadas caminham em direção ao encaixamento, na medida em que adquirem propriedades distribucionais de uma expressão nominal.

\subsection{Abordagem funcional para a complementação: enquadramento teórico}

É necessário abrir um parêntese para iniciar uma reflexão sobre a teoria adotada e outras teorias. O capítulo anterior delimitou a análise dos tipos de completivas a partir de um enfoque funcionalista, excluindo o enfoque tradicional e o aparato formal. Mais uma vez, é preciso delimitar um pouco mais o enfoque teórico que sustentará a descrição dos dados analisados e a consequente explicação para o fenômeno observado.

Diferentemente do que ocorreu no Capítulo 1, delimitar o tipo de enfoque teórico não significa, entretanto, abrir mão das perspectivas para a complementação aqui apresentadas. Ao contrário, as noções apresentadas por Givón (1980, 1993), Cristofaro (2003), Noonan (1985), Lehmann (1988) e por todos os outros autores visitados ao longo deste capítulo representam questões cruciais para a investigação proposta neste trabalho e servem como base para as hipóteses e interpretações aqui apresentadas.

É sabido que esta tese prevê o processo de integração semântica (cf. GIVÓN, 1980, 1993; Cristofaro, 2003) como determinante para seleção/restrição dos tipos de completivas, tanto que trata da relação da sintaxe com a semântica. Entretanto, o tratamento fornecido pela GDF (HENGEVELD; MACKENZIE, 2008) às relações de complementação consegue abrigar convenientemente, nos diferentes níveis e camadas propostos, os pressupostos de Givón (1980, 1993) e de Cristofaro (2003), que, em geral, dispensam um grau menor de formalização. A GDF incorpora em seus níveis e camadas de representação a intuição 
givoniana $(1980,1993)$ sobre integração semântica, acomodando formalmente as tendências observadas por Givón e outros linguistas. Desse modo, é esse o principal modelo teórico que serve como suporte teórico para este trabalho. ${ }^{49}$

A GDF estabelece uma interface entre a configuração formal, sintática, da linguagem e os subsistemas semântico e pragmático; para tanto, enfoca não só as regras que governam a constituição das expressões linguísticas, isto é, a linguagem de um ponto de vista representacional, mas também as que governam os padrões de interação verbal nos quais essas expressões são usadas, ou melhor, a linguagem de um ponto de vista interpessoal. Para a análise aqui proposta, é extremamente relevante um modelo teórico que conceba a gramática como um componente seriamente comprometido com a interação entre os níveis pragmático, semântico e morfossintático, como faz a GDF.

\section{- Breve recapitulação}

Este capítulo abordou o modo como a subordinação completiva é tratada em estudos de orientação funcionalista. O objetivo aqui foi o de tratar das relações que se estabelecem entre as orações envolvidas no fenômeno da complementação e, mais especificamente, da semântica do predicado encaixador, determinante na seleção/restrição do tipo de completiva. Tomou-se como ponto de partida a concepção de subordinação proposta por Cristofaro (2003), segundo a qual a subordinação constitui um modo de construir uma relação cognitiva entre dois estados de coisas, de um modo tal que a um deles falta um perfil autônomo, sendo, por isso, construído a partir da perspectiva do outro estado de coisas. A relação estabelecida entre predicado encaixador e oração completiva foi tratada a partir da noção de integração

\footnotetext{
49 A opção pelo aparato teórico da GDF não se trata de um ecletismo barato, tampouco de seleção avaliativa negativa. Givón $(1980,1990)$ formaliza pouco suas colocações, assim como Cristorafo (2003), que tem uma visão mais cognitivista, mesmo porque essa não é a proposta dos autores. Por isso, afirmo que, no tratamento da complementação com vistas à explicação para a seleção/restrição de complementos, as propostas pouco formalizadas de Givón e de Cristofaro abrigam-se perfeitamente na proposta formalizada da GDF.
} 
semântica, introduzida originalmente por Givón $(1980,1993)$ e considerada, por Cristofaro (2003), um dos parâmetros por meio dos quais se pode descrever a semântica da subordinação. Focalizando os tipos de construções completivas, este capítulo tratou da gradação entre construções encaixadas verbais e nominais, abordando a sentencialidade e a nominalidade das completivas, com base no tratamento que Noonan (1985), KoptjevskajaTamm (1993), Mackenzie (1996), Dik (1997b), Cristofaro (2003) e Malchukov dão ao tema. Finalmente, delimitou-se aqui como principal embasamento teórico a GDF (HENGEVELD; MACKENZIE, 2008), a ser discutida no próximo capítulo. Obviamente, essa delimitação não elimina, de modo algum, os outros enfoques de cunho funcionalista apresentados neste capítulo. Ao contrário, o modelo teórico escolhido é capaz de abrigar os pressupostos desses outros enfoques. 


\section{CAPÍTULO 3}

\section{A GRAMÁTICA DISCURSIVO-FUNCIONAL}

\subsection{Considerações iniciais}

A GDF é o modelo mais recente da Teoria da Gramática Funcional (Dik, 1997a, 1997b). Esse novo modelo não se restringe às orações, tal como nessa versão standard, mas abrange tanto as unidades maiores quanto as menores do que as orações, buscando descrevêlas a partir da aplicação de quatro níveis de análise, que dão conta das motivações pragmáticas e semânticas da formulação morfossintática, além de representarem os aspectos estruturais e prosódicos da codificação dos enunciados.

Neste capítulo, apresento o arcabouço geral da GDF, que, conforme especificado no capítulo anterior, constitui a base teórica principal sobre a qual se fundamenta este trabalho. Por uma questão de espaço e pertinência, não pretendo aqui sintetizar todos os princípios do modelo; almejo simplesmente explicitar as bases gerais sobre os quais essa teoria linguística se assenta, como um subsídio para a sustentação teórico-metodológica do trabalho. Em função disso, a seção 3.2 descreve a GDF, enfatizando os princípios que a regem, suas características como um modelo de interação verbal e seu modo de organização. A seção 3.3 focaliza os aspectos semânticos da unidade linguística, caracterizando as categorias semânticas relevantes para a análise de qualquer língua. Dado que a arquitetura da GDF é dotada de níveis separados de organização interpessoal, representacional e morfossintática, a seção 3.4 trata da noção de alinhamento, com ênfase no alinhamento representacional. A seção 3.5 apresenta o tratamento que a GDF dispensa à subordinação, salientando o modo como esse modelo teórico descreve as estruturas completivas, especificamente no que tange à caracterização dos predicados encaixadores de complemento. 


\subsection{O modelo da Gramática Discursivo-Funcional}

A GDF faz parte do leque de teorias linguísticas que se baseiam na crença de que as propriedades da expressão linguística adaptam-se às intenções comunicativas do usuário da língua. Como parte de uma ampla teoria de interação verbal, situa-se no campo das teorias funcionalmente orientadas e, como tal, considera que a pragmática governa a semântica, a pragmática e a semântica governam a morfossintaxe, e a pragmática, a semântica e a morfossintaxe governam a fonologia.

$\mathrm{Na}$ escala de teorias formal ou funcionalmente orientadas apresentada no Capítulo 1 (p. 49), a GDF ocupa uma posição intermediária entre abordagens radicalmente funcionalistas e radicalmente formalistas. Segundo Hengeveld (2004b), a GF, bem como sua nova versão, é um modelo comprometido com a orientação funcional com o objetivo explícito de construir um sistema de representação formal. Esse sistema de representação formal, caracterizado pela introdução de variáveis, níveis e módulos de representação, está diretamente envolvido com a necessidade de caracterizar a função comunicativa da linguagem, integrando, portanto, aspectos comunicacionais na própria arquitetura do modelo formal.

A GDF é, então, um modelo das intenções e conceituações codificadas, uma vez que procura entender a maneira como as unidades linguísticas se estruturam e as intenções comunicativas que as motivam, modelando esses objetivos em uma implementação dinâmica da gramática. Isso significa dizer que essa teoria não é um modelo da produção linguística: é uma teoria sobre a gramática das línguas que procura fazer uso de evidências psicolinguísticas em sua arquitetura básica (cf. HENGEVELD; MACKENZIE, 2008). O usuário da língua é visto como um conhecedor das unidades e dos modos como essas unidades podem se combinar (em atos discursivos, proposições, por exemplo). Como um modelo de representação, a GDF busca descrever o conhecimento subjacente ao potencial comunicativo do usuário da língua de modo explícito e altamente formalizado, na medida em que adere a 
um sistema notacional sofisticado. Assume, entretanto, que o conhecimento que o falante tem da língua (isto é, de suas unidades e combinações) é um instrumento na comunicação interpessoal e emerge como resultado de processos históricos: formas que serviram aos falantes ao longo do tempo sedimentaram-se em um repertório agora disponível aos usuários da língua e estão muito bem adaptadas aos seus propósitos comunicativos.

Como parte de uma teoria de interação verbal, a GDF caracteriza-se por (i) sua organização top-down, (ii) tomar o ato discursivo como unidade básica de análise, (iii) incluir representações morfossintáticas e fonológicas como parte da estrutura subjacente, ao lado de representações das propriedades semânticas e pragmáticas dos atos discursivos, (iv) ligar, sistematicamente, os componentes Conceitual, Contextual e de Output.

$\mathrm{Na}$ proposta da GDF, a gramática está disposta em níveis, que, por sua vez, estão dispostos em camadas hierarquicamente organizadas. Os níveis dão conta de motivações pragmáticas e de motivações semânticas e representam os aspectos estruturais e prosódicos da codificação dos enunciados. A organização em camadas é um princípio já defendido na versão anterior do modelo da Teoria da Gramática Funcional (DIK, 1997a, 1997b; HENGEVELD, 1989, 1990a). Hengeveld e Mackenzie (2008) alegam que um modelo de gramática é tanto mais efetivo quanto mais sua organização se assemelhar ao processamento linguístico; assim, como a produção começa com as intenções comunicativas processando em direção descendente até chegar à articulação da expressão, o modelo de produção gramatical deve refletir esse modo de processamento, sendo organizado de modo descendente, do discurso para as unidades de expressão.

Nessa organização top-down, pode-se distinguir duas operações: a de Formulação, que tem a ver com as regras que determinam quais representações semânticas e pragmáticas subjacentes são válidas, e a de Codificação, que tem a ver com as regras que convertem essas representações semânticas e pragmáticas em representações morfossintáticas e fonológicas. A 
operação de Formulação envolve tanto a seleção de esquemas apropriados para os níveis Interpessoal e Representacional quanto a inserção de lexemas apropriados nesses esquemas, além da aplicação de operadores que representem as distinções gramaticais requeridas pela língua em análise. A operação de Codificação, por sua vez, envolve tanto a seleção de moldes (templates) apropriados para os níveis Morfossintático e Fonológico quanto a inserção de morfemas gramaticais, além da aplicação de operadores que cumprem um papel no processo de articular o output da gramática.

A GDF sustenta que a unidade básica de análise é o ato discursivo, em oposição à oração (clause), tal como preconizava o modelo standard da Teoria da Gramática Funcional. Em relação ao modelo anterior, houve uma mudança da centralidade no predicado para a centralidade na pragmática e a divisão da representação subjacente da versão standard em quatro níveis distintos (cf. ANSTEY, 2004).

Apesar de defender uma metodologia funcional para o enfoque da linguagem e apesar da prioridade metodológica que parece merecer o componente pragmático nos estudos funcionalistas, o principal centro de atenção da GF é a estrutura da oração simples e complexa. Como bem aponta Camacho (2006), ainda que, frequentemente, a abordagem dos fenômenos gramaticais lance mão de explicações de base discursiva, tendo em vista que a linguagem é um instrumento de interação social, a sintaxe em si, e não o discurso, parece ser o objeto principal da GF, visto que a unidade máxima de análise está confinada ao estudo de construções simples (DIK, 1997a) e complexas (DIK, 1997b).

Nos casos em que a explicação reduz as regras aos mecanismos formais, a GF dá conta apenas da sintaxe, deixando de lado a prioridade das regras pragmáticas e semânticas, um de seus postulados mais caros. Dik (1997a, p. 5) acredita que "o correlato psicológico de uma língua natural é a 'competência comunicativa' do ULN [usuário de língua natural] no sentido 
de Hymes (1972): sua habilidade de estabelecer a interação social por meio da linguagem". 50 Não obstante, Hymes (1979, p. 306) lança mão da seguinte crítica a Dik: "Seria justo dizer que Dik entende ser preferível que a GF seja um modo de analisar a gramática como meio de comunicação, mas deixa a análise dos fins da comunicação, e a ligação entre meios e fins, para outros ou para um outro momento". 51

Desde o começo dos anos 90, uma parte significativa da pesquisa desenvolvida dentro da GF voltou-se para a expansão de um modelo sentencial para um modelo discursivo de gramática. Segundo Hengeveld (2004a), houve duas razões para essa expansão: em primeiro lugar, há muitos fenômenos linguísticos que somente podem ser explicados em termos de unidades maiores que a sentença individual: partículas discursivas, cadeias anafóricas, formas verbais narrativas etc.; em segundo lugar, há muitas expressões linguísticas que são menores do que a sentença individual, mas funcionam como enunciados completos e independentes dentro do discurso. Isso, portanto, requereria uma concepção de enunciados como atos discursivos e não como orações. ${ }^{52}$

Como já mencionado, as operações distinguidas pela GDF dão conta de dois níveis de análise linguística para a Formulação e de dois níveis para a Codificação. Em outras palavras, a GDF postula a necessidade de uma gramática organizada em quatro níveis, cada qual concebido como um módulo separado e organizado internamente em camadas: os níveis Interpessoal e Representacional, associados às operações de Formulação, e os níveis Morfossintático e Fonológico, associados às operações de Codificação, conforme se vê de modo simplificado na Figura 3-1 (p. 109).

\footnotetext{
${ }^{50} \mathrm{Cf}$. o original: The psychological correlate of a natural language is the NLU's "communicative competence" in the sense of Hymes (1972): his hability to carry on social interaction by means of language.

${ }^{51} \mathrm{Cf}$. o original: It might be fair to say that Dik understands FG to be preferable as a way of analyzing grammar as communicative means, but leaves the analysis of communicative ends, and the linkage between means and ends, to others, or for another time.

${ }^{52}$ Os atos discursivos tanto podem se articular entre si, levando à constituição de estruturas discursivas maiores, como os moves, quanto podem se manifestar como orações ou fragmentos oracionais gramaticais, sintagmas ou palavras (cf. HENGEVELD; MACKENZIE, 2008).
} 
Uma das razões para postular um sistema modular com quatro níveis de representação é a de que é possível fazer referência anafórica em todos os níveis de organização linguística (cf. HENGEVELD, 2005), não apenas a entidades referenciais, como em (3-1), mas também a atos de fala, como em (3-2), à forma de sintagmas nominais, como em (3-3), e à própria expressão fonológica, como em (3-4).

(3-1) Nível Interpessoal
A. Saia já daqui!
B. Não me fale assim!

(3-2) Nível Representacional
A. Há muitos sinais de trânsito nesta cidade.
B. Eu não havia notado isso.

(3-3) Nível Morfossintático
A. Eu comi 'lamb chop' ontem à noite.
B. É assim que você diz 'costela de carneiro' em inglês?

(3-4) Nível Fonológico
A. Eu comi uma /pa'èa / ontem à noite.
B. Isso não seria/pa'eyal

(Adaptado de HENGEVELD, 2005, p. 59)

Todos os níveis têm uma natureza puramente linguística no sentido estrito de que descrevem a linguagem com base nas funções que ela permite exercer, mas somente na medida em que essas funções são codificadas na gramática das línguas particulares; nesses termos, a GDF é o componente gramatical de uma teoria mais abrangente da interação verbal.

Os Níveis Interpessoal, pragmático, e Representacional, semântico, descrevem a língua quanto às suas funções e significados, mas somente as funções e significados que são codificados pela morfossintaxe da língua. Desse modo, o Nível Interpessoal representa a unidade linguística em termos de função comunicativa, enquanto o Nível Representacional representa a unidade linguística em termos de categoria semântica. No Nível Morfossintático, 
as unidades linguísticas são analisadas em termos de seus constituintes sintáticos, da camada mais alta para a mais baixa: expressão linguística, oração, sintagmas e palavras. O Nível Fonológico, por sua vez, contém as representações fonológicas segmental e suprassegmental da elocução. Isso significa que, nesse nível, a expressão linguística é analisada quanto às unidades fonológicas que ela contém.

No Nível Interpessoal, a unidade de análise é o move, que pode conter um ou mais atos discursivos. ${ }^{53}$ Os atos discursivos, por sua vez, contêm uma ilocução que especifica a relação entre os participantes do ato de fala e o conteúdo comunicado (formado por um número variável de subatos atributivo e referencial), que contém a totalidade do que o falante deseja evocar em sua comunicação. No Nível Representacional, as unidades de análise linguística são descritas em termos de categoria semântica que elas designam. Essas categorias são de diferentes tipos, tais como conteúdo proposicional, episódios, estado de coisas, propriedades e indivíduos. Nos diferentes níveis de análise associados à operação de Formulação, modificadores atuam nas diferentes camadas de representação.

As operações de Formulação e Codificação estão contidas no componente Gramatical. Um avanço importante na GDF é o reconhecimento dos componentes Contextual e Conceitual, que contêm elementos essenciais do contexto com o qual os três módulos interagem. O componente Gramatical conecta-se ao componente Conceitual, ao Contextual e aos componentes de expressão (Output). Assim, representações morfossintáticas e fonológicas são níveis separados dentro do componente Gramatical em vez de serem parte apenas do Output da gramática, como era previsto no modelo standard (DIK, 1997a). No Output do sistema, reside apenas a expressão, reduzida à articulação fonética. O Output da gramática funciona como input para a operação de articulação, que, no caso mais comum de expressão, a acústica, contém as regras fonológicas necessárias para um enunciado fonético adequado.

\footnotetext{
${ }^{53} \mathrm{O}$ move (lance) constitui uma unidade autônoma de discurso com o efeito perlocucionário de provocar uma reação. Ele descreve um segmento inteiro com as várias camadas inferiores que, por seu lado, contêm componentes desse segmento, uma hierarquia que representa a sequência das ações linguísticas.
} 


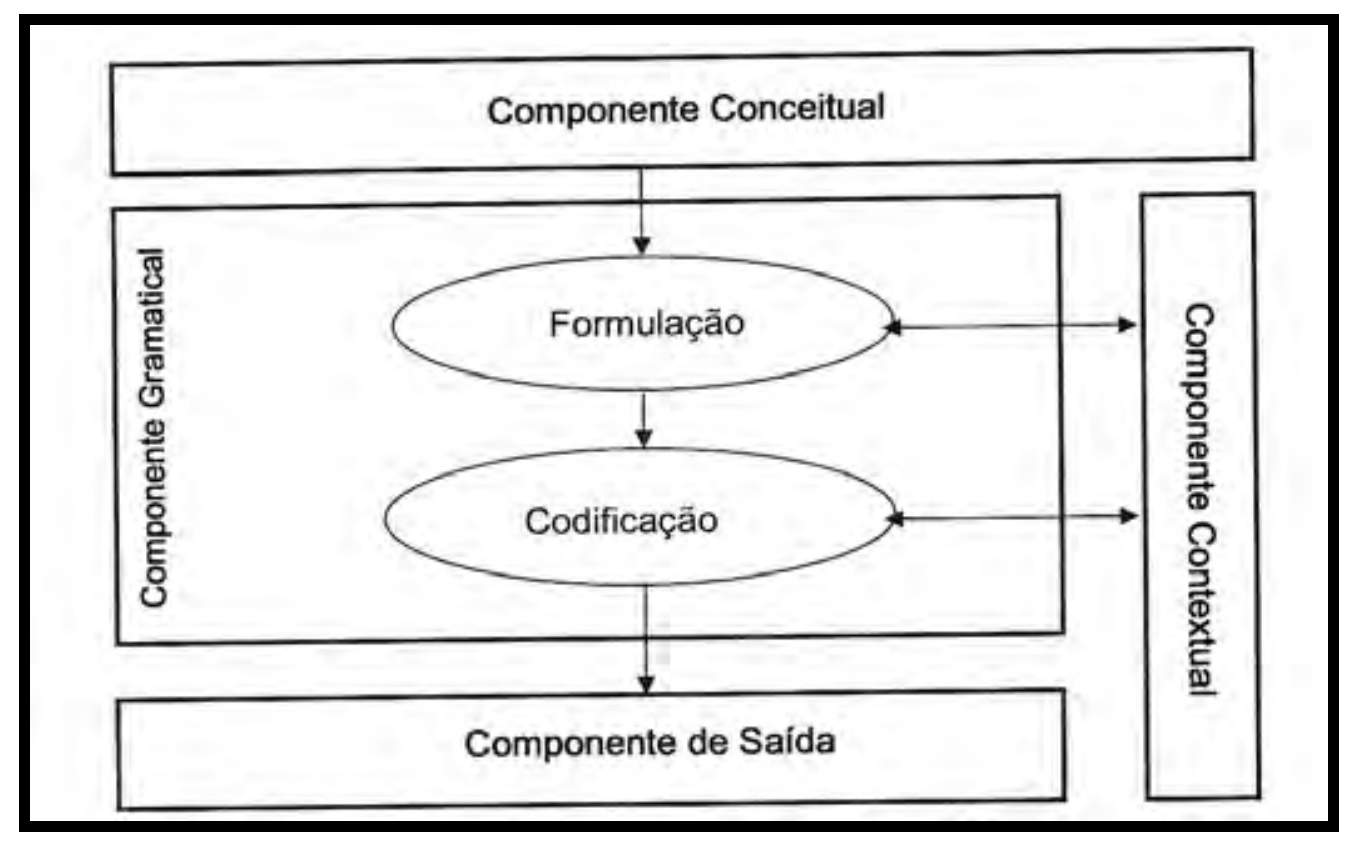

Figura 3-1: GDF como parte de uma teoria de interação verbal (adaptado de HENGEVELD; MACKENZIE, 2008, p. 6)

O componente Conceitual é a força motriz subjacente ao componente Gramatical. É esse componente que representa o material ideacional e interativo pressuposto para cada peça do discurso em análise e para os vários moves e atos discursivos que ele contém. $\mathrm{O}$ componente Conceitual não inclui todos os aspectos da cognição que são relevantes à análise linguística, mas inclui os que afetam as intenções comunicativas imediatas. O componente Output converte as estruturas finais do componente Gramatical em sinais acústicos, quando se trata da fala, em expressões ortográficas, quando se trata de língua escrita, e em gestos manuais e corporais, quando se trata de língua de sinais. O componente Contextual abriga a informação imediata recebida do componente Gramatical, a qual diz respeito a um enunciado particular que é relevante para a forma dos enunciados subsequentes. Esse componente contém a informação de longo termo sobre a interação em curso, que é relevante para as distinções requeridas pela língua em uso e que influencia na formulação e codificação dessa língua (cf. HENGEVELD; MACKENZIE, 2008).

Uma representação completa do modelo está disposta na Figura 3-2: 


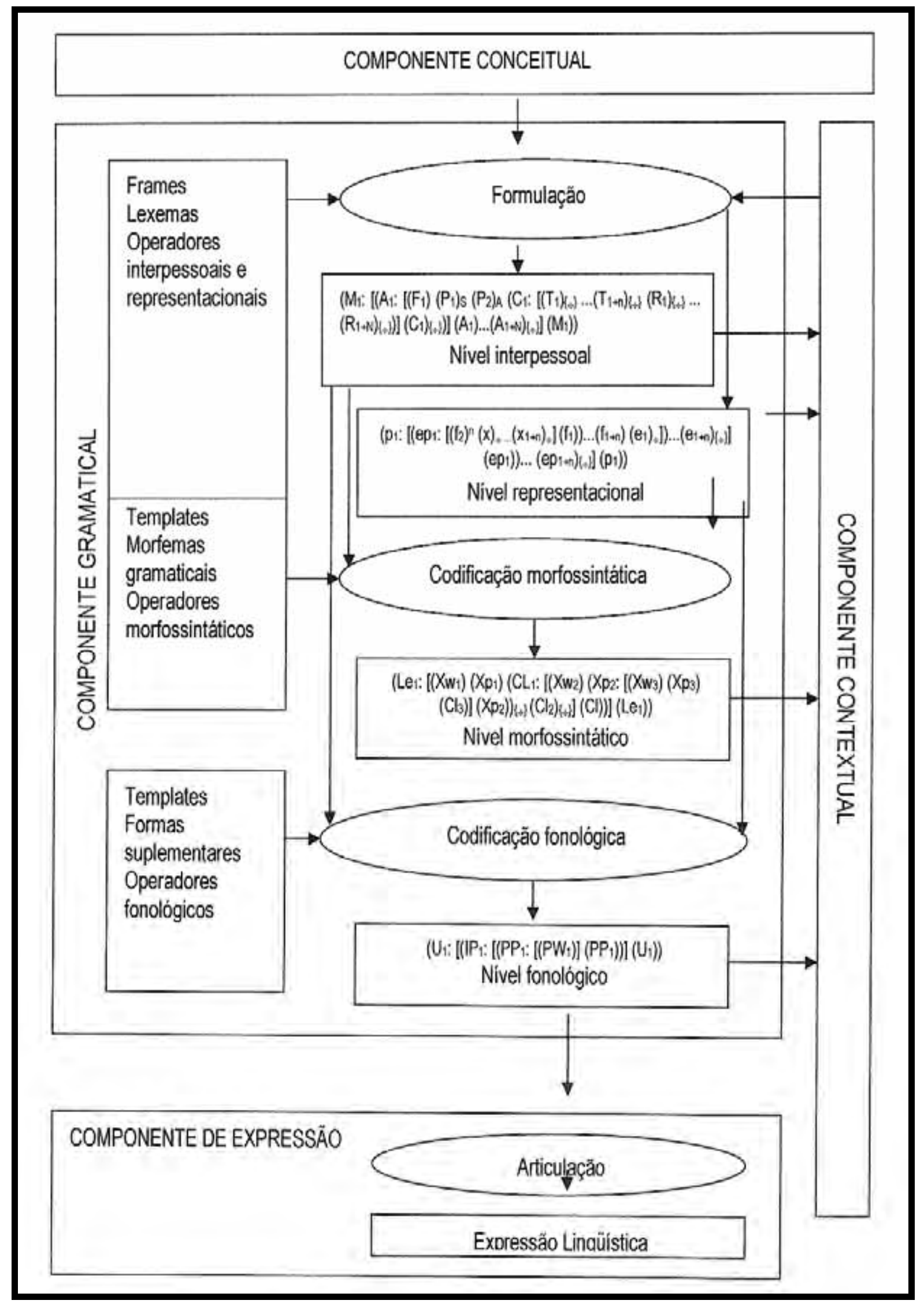

Figura 3-2: Arquitetura geral da GDF (adaptado de HENGEVELD; MACKENZIE, 2008, p. 13) 
O componente Conceitual abriga as intenções comunicativas e as representações mentais ou cognitivas correspondentes. Pela operação de Formulação, essas representações conceituais são traduzidas em representações pragmáticas e semânticas nos níveis Interpessoal e Representacional, respectivamente. As regras de Formulação se valem de um conjunto de primitivos que incluem estruturas, lexemas e operadores.

As configurações dos níveis Interpessoal e Representacional são traduzidas em estruturas morfossintáticas no Nível Morfossintático por meio de operações de codificação. As regras de codificação morfossintática recorrem a um conjunto de primitivos que contêm moldes (templates) morfossintáticos, morfemas gramaticais e operadores morfossintáticos. Igualmente, as estruturas dos níveis Interpessoal, Representacional e Morfossintático são traduzidas em estruturas fonológicas no Nível Fonológico. As regras de codificação fonológica recorrem a um conjunto de primitivos que incluem moldes (templates) fonológicos, formas supletivas e operadores fonológicos.

Cada um dos níveis de representação que integram o componente Gramatical tem uma estrutura independente, como nas próprias camadas. Em cada nível, a expressão linguística é analisada em termos de distinções relevantes para o nível em questão. O que eles têm em comum é o fato de terem uma organização em camada hierarquicamente ordenada. Nos níveis Interpessoal e Representacional, a estrutura geral para camadas é a que segue:

$$
\left(\pi \mathrm{v}_{1}:\left[\mathrm{h}\left(\mathrm{v}_{1}\right)_{\Phi}\right]:\left[\sigma\left(\mathrm{v}_{1}\right)_{\Phi}\right]\right)
$$

No formalismo da GDF, (v) corresponde à variável da camada relevante (como, por exemplo, move, atos discursivos etc., no Nível Interpessoal, e conteúdo proposicional, estados de coisas etc., no Nível Representacional); essa variável é restringida por um núcleo (h) (possivelmente complexo) que a toma como seu argumento e pode, além disso, ser restringida por um modificador $(\sigma)$ que toma a variável como seu argumento. Cada núcleo (h [de head]) pode ser modificado por um ou mais modificadores $(\sigma)$ e cada variável pode ser especificada 
por um ou mais operadores $(\pi)$; as unidades de cada nível podem apresentar uma função $(\Phi)$, semântica ou pragmática. Núcleos e modificadores representam estratégias lexicais, enquanto operadores e funções representam estratégias gramaticais.

No Nível Interpessoal, um move pode ser modificado por elementos do léxico que especificam o papel dele na progressão do discurso (como em 'para encurtar a história, eu ainda o considero capaz, mas duvido que ele consiga'). O modificador de ato discursivo, por sua vez, permite ao falante fazer comentários, indicando as propriedades estilísticas do ato (como 'brevemente'), o estatuto do ato dentro do move (como 'além disso') e atos enfáticos, que expressam raiva, irritação etc. (como em 'vamos embora, caramba'). O modificador de ilocução age sobre o predicado ilocucionário, lexical ou abstrato, e não sobre o ato discursivo como um todo. O modificador de participantes é possível onde haja uma especificação restritiva do núcleo; o falante indica uma face de si próprio ou do ouvinte que é relevante para a ilocução, ou seleciona um ouvinte particular. Modificadores de conteúdo comunicado, por fim, podem ser enfáticos, indicando que se enfatiza conteúdo do enunciado (como em 'eu realmente não gosto de você'), podem também indicar a atitude subjetiva do falante em relação ao que está sendo comunicado (como '(in)felizmente', 'com sorte') e servem para indicar que o falante está transmitindo um conteúdo comunicado expresso ou implicitado por outros - modificadores reportativos - (como 'segundo X', 'aparentemente', 'supostamente').

No Nível Representacional, modificadores de conteúdos proposicionais relacionam a especificação de atitudes proposicionais, que se referem ao tipo e ao grau de comprometimento de um ser racional com o conteúdo proposicional, ou a especificação de fonte (não-verbal, já que é inferido de percepção ou conhecimento) desse conteúdo (como em 'provavelmentelevidentemente/felizmente/indubitavelmentelaparentemente Ana está mal'). Modificadores de episódio servem para localizar temporalmente um episódio como um todo com relação ao episódio precedente (como, por exemplo, 'depois de', 'antes de'); locação 
absoluta de tempo (como o ano passado, a semana passada, ontem etc.) é propriedade de episódios, enquanto a locação relativa é propriedade de estados de coisas. Podem-se qualificar estados de coisas em relação às propriedades de sua ocorrência. As principais modificações referem-se a: tempo relativo de ocorrência (como em 'Ana foi embora antes do jantar'), lugar de ocorrência e frequência de ocorrência (como em 'Ana trabalha em Rio Preto/frequentemente), estatuto de realidade (como em 'Ana é, verdadeiramente, uma mulher'), cenário físico e cenário cognitivo. Modificadores de propriedade configuracional introduzem outros participantes no estado de coisas, que estão cognitivamente presentes no componente Conceitual, mas o conjunto disponível de frames não oferece lugar para eles como argumentos. ${ }^{54}$ Uma propriedade lexical pode ser modificada por outra propriedade lexical, resultando propriedades complexas. As unidades que designam indivíduo podem ser qualificadas por modificadores, lexical ou complexo, exceto aqueles com o núcleo ausente.

Tendo fornecido um quadro geral do modelo, passo a considerar especificamente, na próxima seção, as propriedades do Nível Representacional que interessam diretamente ao tratamento das completivas. O Nível Representacional trata dos aspectos semânticos de uma unidade linguística e é nele que se apresentam as categorias semânticas básicas que são relevantes para a análise de qualquer língua.

\subsection{As categorias semânticas na Gramática Discursivo-Funcional}

Na GDF, o termo 'semântica' tem dois sentidos diferentes. Primeiramente, restringese ao modo como a língua se relaciona com o mundo extralinguístico que ela descreve. $\mathrm{O}$

\footnotetext{
${ }^{54}$ Propriedades configuracionais constituem um inventário de esquemas de predicação relevantes para as línguas e representam uma regra crucial na construção de representações semânticas. A propriedade configuracional é composicional por natureza e contém uma combinação de categorias semânticas sem relação hierárquica entre si. Essas categorias semânticas de tipos variados podem incluir indivíduos (x), consistindo em objetos concretos que podem ser localizados no espaço e no tempo, e categorias lexicais (f), que não têm uma existência independente e podem ser somente avaliadas em termos de sua aplicabilidade a outros tipos de entidades. Outras categorias semânticas, relevantes para a gramática das línguas individuais, que podem participar da constituição de uma Propriedade Configuracional são lugar (l), tempo (t), modo (m), razão (r) e quantidade (q) (cf. HENGEVELD; MACKENZIE, 2008).
} 
verbo insistir em (3-6a), por exemplo, usado performativamente, tem a função de identificar explicitamente o valor ilocucionário do enunciado em um conjunto comunicativo particular. A função, então, não é a de descrever o que um indivíduo está fazendo em um momento particular do tempo. Isso se torna evidente pela aplicação da negação Isso não é verdade que afeta somente Ana está doente, como mostra (3-6a'), e não o ato performativo em si (*3-6a')).

(3-6)a. Eu insisto que Ana está doente.

a'. Isso não é verdade (Ela não está doente)

*a”. Isso não é verdade (Você não insiste)

(Adaptado de HENGEVELD; MACKENZIE, 2008, p. 128)

Isso não ocorre, entretanto, com um uso não-performativo de insistir em (3-7a). A negação Isso não é verdade pode valer tanto para Ana está doente quanto para Pedro insistiu:

(3-7)a. Pedro insistiu que Ana está doente.

a'. $\quad$ Isso não é verdade. (Ela não está doente)

a’’. Isso não é verdade. (Ele não insistiu)

(Adaptado de HENGEVELD; MACKENZIE, 2008, p. 128)

O problema que (3-6a) levanta para a semântica não se aplica somente a expressões lexicais de ilocução, tal como o performativo ali contido, mas também à força ilocucionária, expressa lexicalmente, indicando uma estratégia, e a todos os tipos de modificadores no Nível Interpessoal. Observem-se as ocorrências em (3-8) e (3-9):

(3-8)a. Francamente/Resumidamente/Finalmente, Ana está doente.

b. Não. (Ela não está doente)

*c. Não. (Você não está sendo franco)

*d. Não. (Isso não é breve)

*e. Não. (Isso não é final) 
(3-9)a. Pedro disse-me francamente que Ana está doente.

b. Isso não é verdade. (Ela não está doente)

c. Isso não é verdade. (Ele não disse a você)

d. Isso não é verdade. (Ele não estava sendo franco)

(Adaptado de HENGEVELD; MACKENZIE, 2008, p. 129)

Os elementos interpessoais em (3-8) não estabelecem uma relação com o mundo externo, mas atuam no âmbito interno da situação de interação.

(3-10)*a. Pedro disse-me que francamente Ana está doente.

*b. Pedro disse-me que resumidamente Ana está doente.

*c. Pedro disse-me que finalmente Ana está doente.

(Adaptado de HENGEVELD; MACKENZIE, 2008, p. 129)

A impossibilidade ou a possibilidade de elementos ocorrerem em uma fala indireta pode ser usada como teste para diagnosticar o status interpessoal ou representacional de uma elocução.

O termo 'semântica' pode também se restringir aos significados das unidades lexicais (semântica lexical) e das unidades complexas (semântica composicional), independentemente do modo como são usadas na comunicação. No Nível Interpessoal, trata-se do uso que se faz dessas unidades em termos de atos discursivos e subatos que especificam a função das unidades linguísticas. É possível demonstrar a relevância dessa distinção com base na noção de referência. Observe-se (3-11):

(3-11) Eu vi um leão.

(Adaptado de HENGEVELD; MACKENZIE, 2008, p. 129)

A GDF considera que há duas maneiras para considerar um leão como uma expressão referencial: (i) o falante se refere a um animal da classe dos leões pelo uso dessa expressão, 
numa perspectiva interpessoal, evocando um ato de referenciação; (ii) a expressão se refere a um animal da classe dos leões, numa visão representacional, semântica, isto é, designativa. O exemplo em (3-12) representa um uso muito mais atributivo do que referencial para a expressão um leão; isso mostra que nem sempre uma expressão que designa um leão é usada necessariamente para se referir a um leão. A expressão em (3-13), por sua vez, tem um uso referencial.

(3-12) Esse animal é um leão.

(Adaptado de HENGEVELD; MACKENZIE, 2008, p. 129)

(3-13) No zoológico, eu vi um leão.

(Adaptado de HENGEVELD; MACKENZIE, 2008, p. 130)

Dado que as unidades no Nível Representacional se caracterizam pela denotação, a diferença entre as unidades desse nível pode ser feita em termos da categoria ontológica denotada. Na medida em que categorias ontológicas estão refletidas no sistema da língua, elas têm o estatuto de categoria semântica e cada uma tem sua própria variável na representação que a GDF propõe para as relações semânticas.

Hengeveld e Mackenzie (2008) consideram que há um número definido de categorias semânticas relevantes para a análise de qualquer língua. Para a classificação de categorias semânticas, a GDF toma por base a classificação postulada por Lyons (1977), que distingue três tipos de entidades de ordens diferentes (entidades de primeira, de segunda e de terceira ordem), mas, a essa lista, acrescenta uma categoria mais, a de propriedades.

\begin{tabular}{|lcc|}
\hline \multicolumn{1}{|c|}{ Descrição } & Variável & Exemplo \\
Indivíduo & $\mathrm{x}$ & cadeira \\
Propriedade & $\mathrm{f}$ & cor \\
Estado de coisas & $\mathrm{e}$ & reunião \\
Conteúdo proposicional & $\mathrm{p}$ & ideia \\
\hline
\end{tabular}

Quadro 3-1: Categorias semânticas (cf. HENGEVELD; MACKENZIE, 2008, p. 131) 
Com base no Quadro 3-1, inicialmente, para os propósitos deste trabalho, os tipos de entidades básicas relevantes para o tratamento dado à complementação são conteúdo proposicional, estados de coisas e propriedade. Por sua natureza, indivíduos não funcionam como complemento oracional de sentenças complexas, já que constituem uma entidade de primeira ordem: trata-se de uma entidade concreta, tangível, que pode ser localizada no espaço e avaliada em termos de sua existência.

Conteúdos Proposicionais, as unidades mais altas do Nível Representacional, representam construtos mentais, como conhecimento, crenças e esperanças. Podem ser factuais, quando eles representam conhecimentos ou crenças racionais acerca do mundo real, ou não-factuais, quando envolvem esperanças ou desejos em relação ao mundo imaginário. Em função de sua natureza, uma característica dos conteúdos proposicionais é que eles podem ser qualificados em termos de atitudes proposicionais (certeza, dúvida e descrença) e/ou em termos de suas fontes ou origens (conhecimento comum compartilhado, evidência sensorial e inferência).

Estados de coisas, que incluem eventos e estados, são entidades de segunda ordem e se caracterizam por serem localizáveis no tempo e serem avaliáveis em termos de seu estatuto real. O traço temporal é o que distingue estados de coisas de indivíduos, entidades de primeira ordem, e de conteúdos proposicionais, entidades de terceira ordem.

A essas três categorias semânticas básicas, Hengeveld e Mackenzie (2008) acrescentam mais uma, a de propriedade, que não é caracterizada em termos de tempo e espaço, tal como o são as entidades de primeira, de segunda e de terceira ordem. Propriedades não têm existência independente e só podem ser avaliadas em termos de sua aplicabilidade a outros tipos de entidades, ou à situação que elas descrevem em geral.

Além dessas quatro categorias semânticas, A GDF considera que muitas línguas são sensíveis a uma categoria semântica especial, os episódios. Conteúdos proposicionais contêm 
episódios que constituem, por sua vez, conjuntos de estados de coisas; como tais, são tematicamente coerentes por revelarem unidade ou continuidade de tempo, lugar e indivíduos.

Desse modo, os tipos de unidades semânticas consideradas para o tratamento de construções encaixadas são os que aparecem no Quadro 3-2: ${ }^{55}$

\begin{tabular}{|c|c|c|}
\hline Descrição & Variável & Exemplo \\
\hline Indivíduo & $\mathrm{x}$ & cadeira \\
\hline Propriedade & $\mathrm{f}$ & cor \\
\hline Estado de coisas & $\mathrm{e}$ & reunião \\
\hline Episódio & ep & incidente \\
\hline Conteúdo proposicional & $\mathrm{p}$ & ideia \\
\hline
\end{tabular}

Quadro 3-2: Categorias semânticas (adaptado de HENGEVELD; MACKENZIE, 2008, p. 136)

A configuração padrão básica usada no Nível Representacional é a descrição de um estado de coisas com um núcleo complexo (cf. HENGEVELD; MACKENZIE, 2008, p. 139):

$(3-14) \quad\left(\pi \mathrm{e}_{1}:\left[\left(\mathrm{f}_{1}:\left[\left(\mathrm{f}_{2}\right)\left(\mathrm{x}_{1}\right)_{\Phi}\left(\mathrm{l}_{1}\right)_{\Phi}\left(\mathrm{t}_{1}\right)_{\Phi} \ldots\right]\left(\mathrm{f}_{1}\right)\right)\left(\mathrm{e}_{1}\right)_{\Phi}\right]:\left[\sigma\left(\mathrm{e}_{1}\right)_{\Phi}\right]\right)$

A representação em (3-14) mostra que o estado de coisas (e) é caracterizado por uma propriedade complexa $\left(\mathrm{f}_{1}\right)$, chamada, na GDF, de propriedade configuracional, que é uma combinação de unidades semânticas, que não estão em uma relação hierárquica entre si, incluindo propriedade $\left(\mathrm{f}_{2}\right)$, indivíduo $(\mathrm{x})$, lugar $(\mathrm{l})$, tempo $(\mathrm{t})$ etc. A possibilidade de combinação dessas unidades semânticas é explicável em termos de esquemas de predicação. No formalismo da GDF, o símbolo $\pi$ é usado para operadores; $\sigma$, por sua vez, representa um modificador e $\Phi$, a função semântica.

\footnotetext{
${ }^{55}$ Hengeveld e Mackenzie (2008) utilizam dois critérios para identificar as categorias semânticas: (i) a existência de classes lexicais e (ii) modelos de nominalizações. Com base no segundo critério, depreendem outras categorias semânticas que podem não ser relevantes para todas as línguas, a saber: lugar (l), tempo (t), modo (m), razão (r) e quantidade (q). As categorias semânticas distinguidas pela GDF somente são relevantes se, na língua observada, há fenômenos gramaticais sensíveis a elas.
} 
No esquema de predicação, há um núcleo e seus dependentes (a dependência evidenciase pela presença de uma função semântica). A estrutura pode ser assim generalizada (cf. HENGEVELD; MACKENZIE, 2008, p. 139):

$(3-15) \quad\left(\pi \mathrm{e}_{1}:\left[\left(\mathrm{f}_{1}:\left[\left(\mathrm{v}_{1}\right)(\mathrm{v})_{\Phi}{ }^{\mathrm{n}}\right]\left(\mathrm{f}_{1}\right)\right)\left(\mathrm{e}_{1}\right)_{\Phi}\right]:\left[\sigma\left(\mathrm{e}_{1}\right)_{\Phi}\right]\right)$

Para uma oração simples como em (3-16a), o estado de coisas é formalmente representado em (3-16b):

(3-16)a. O homem foi ao supermercado

b. $\quad\left(\mathrm{e}_{\mathrm{i}}:\left[\left(\mathrm{f}_{\mathrm{i}}:\left[\left(\mathrm{f}_{\mathrm{j}}: \operatorname{ir}\left(\mathrm{f}_{\mathrm{j}}\right)\right)\left(\mathrm{x}_{\mathrm{i}}:\left[\left(\mathrm{f}_{\mathrm{k}} \text { : homem }\left(\mathrm{f}_{\mathrm{k}}\right)\right)\left(\mathrm{x}_{\mathrm{i}}\right)_{\Phi}\right]\right)_{\Phi}\left(\mathrm{l}_{\mathrm{i}}:\left[\left(\mathrm{f}_{\mathrm{l}} \text { : supermercado }\left(\mathrm{f}_{\mathrm{l}}\right)\right)\left(\mathrm{l}_{\mathrm{i}}\right)_{\Phi}\right]\right)_{\Phi}\right]\right.\right.\right.$ $\left.\left.\left.\left(\mathrm{f}_{\mathrm{i}}\right)\right)\left(\mathrm{e}_{\mathrm{i}}\right)_{\Phi}\right]\right)$

Para haver completa recursividade na estrutura semântica, as posições podem ser preenchidas por unidades semânticas, tanto no esquema de predicação quanto na posição estrutural (slot) de modificadores. A recursividade parece relevante para o tratamento da complementação oracional, na medida em que, a partir dela, unidades menores podem incorporar-se a unidades hierarquicamente superiores. Observe-se o exemplo em (3-17a):

(3-17)a. O homem quer que a mulher saia do hospital.

Para a ocorrência em (3-17a), tem-se a seguinte representação semântica:

(3-17)b. $\quad\left(\mathrm{e}_{\mathrm{i}}:\left[\left(\mathrm{f}_{\mathrm{i}}:\left[\left(\mathrm{f}_{\mathrm{j}}\right.\right.\right.\right.\right.$ : querer $\left.\left(\mathrm{f}_{\mathrm{j}}\right)\right)\left(\mathrm{x}_{\mathrm{i}}:\left[\left(\mathrm{f}_{\mathrm{k}} \text { : homem }\left(\mathrm{f}_{\mathrm{k}}\right)\right)\left(\mathrm{x}_{\mathrm{i}}\right)_{\Phi}\right]\right)_{\Phi}\left(\mathrm{e}_{\mathrm{j}}:\left[\left(\mathrm{f}_{\mathrm{l}}:\left[\left(\mathrm{f}_{\mathrm{m}}:\right.\right.\right.\right.\right.$ sair $\left.\left(\mathrm{f}_{\mathrm{m}}\right)\right)\left(\mathrm{x}_{\mathrm{j}}\right.$ : $\left[\left(\mathrm{f}_{\mathrm{n}}:\right.\right.$ mulher $\left.\left.\left.\left.\left.\left.\left.\left.\left.\left.\left(\mathrm{f}_{\mathrm{n}}\right)\right)\left(\mathrm{x}_{\mathrm{j}}\right)_{\Phi}\right]\right)_{\Phi}\left(\mathrm{l}_{\mathrm{i}}:\left[\left(\mathrm{f}_{\mathrm{o}} \text { : hospital }\left(\mathrm{f}_{\mathrm{o}}\right)\right)\left(\mathrm{l}_{\mathrm{i}}\right)_{\Phi}\right]\right)_{\Phi}\right]\left(\mathrm{f}_{\mathrm{l}}\right)\right)\left(\mathrm{e}_{\mathrm{j}}\right)_{\Phi}\right]\right)_{\Phi}\left(\mathrm{f}_{\mathrm{i}}\right)\right)\left(\mathrm{e}_{\mathrm{i}}\right)_{\Phi}\right]\right)$

Em (3-17b), o esquema de predicação $\left(\mathrm{f}_{\mathrm{i}}\right)$ do estado de coisas $\left(\mathrm{e}_{\mathrm{i}}\right)$ contém uma posição estrutural (slot) para a propriedade $\left(\mathrm{f}_{\mathrm{j}}\right)$, o indivíduo $\left(\mathrm{x}_{\mathrm{i}}\right)$ e para um segundo estado de coisas $\left(e_{j}\right)$. Esse estado de coisas, por sua vez, contém um esquema de predicação $\left(f_{l}\right)$ que contém posições estruturais (slots) para a propriedade $\left(\mathrm{f}_{\mathrm{m}}\right)$, o indivíduo $\left(\mathrm{x}_{\mathrm{j}}\right)$ e o lugar $\left(\mathrm{l}_{\mathrm{i}}\right)$.

Um outro exemplo, agora com uma entidade de ordem mais alta: 
(3-18)a. O homem sabe que a mulher saiu do hospital.

Para a ocorrência em (3-18a), tem-se a seguinte representação semântica:

(3-18)b. $\quad\left(\mathrm{p}_{\mathrm{i}}\right.$ : [(f $\mathrm{f}_{\mathrm{i}}:\left[\left(\mathrm{f}_{\mathrm{j}}: \operatorname{saber}\left(\mathrm{f}_{\mathrm{j}}\right)\right)\left(\mathrm{x}_{\mathrm{i}}:\left[\left(\mathrm{f}_{\mathrm{k}}: \text { homem }\left(\mathrm{f}_{\mathrm{k}}\right)\right)\left(\mathrm{x}_{\mathrm{i}}\right)_{\Phi}\right]\right)_{\Phi}\left(\mathrm{e}_{\mathrm{j}}:\left[\left(\mathrm{f}_{\mathrm{l}}:\left[\left(\mathrm{f}_{\mathrm{m}}: \operatorname{sair}\left(\mathrm{f}_{\mathrm{m}}\right)\right)\left(\mathrm{x}_{\mathrm{j}}\right.\right.\right.\right.\right.\right.$ : $\left[\left(\mathrm{f}_{\mathrm{n}}\right.\right.$ : mulher $\left.\left.\left.\left.\left.\left.\left.\left.\left.\left.\left(\mathrm{f}_{\mathrm{n}}\right)\right)\left(\mathrm{x}_{\mathrm{j}}\right)_{\Phi}\right]\right)_{\Phi}\left(\mathrm{l}_{\mathrm{i}}:\left[\left(\mathrm{f}_{\mathrm{o}}: \text { hospital }\left(\mathrm{f}_{\mathrm{o}}\right)\right)\left(\mathrm{l}_{\mathrm{i}}\right)_{\Phi}\right]\right)_{\Phi}\right]\left(\mathrm{f}_{1}\right)\right)\left(\mathrm{e}_{\mathrm{j}}\right)_{\Phi}\right]\right)_{\Phi}\left(\mathrm{f}_{\mathrm{i}}\right)\right)\left(\mathrm{e}_{\mathrm{i}}\right)_{\Phi}\right]\right)$

Agora, em (3-18b), o esquema de predicação $\left(\mathrm{f}_{\mathrm{i}}\right)$ do conteúdo proposicional $\left(\mathrm{p}_{\mathrm{i}}\right)$ contém uma posição estrutural (slot) para a propriedade $\left(\mathrm{f}_{\mathrm{j}}\right)$, o indivíduo $\left(\mathrm{x}_{\mathrm{i}}\right)$ e para o estado de coisas $\left(\mathrm{e}_{\mathrm{j}}\right)$. Esse estado de coisas, por sua vez, contém um esquema de predicação $\left(\mathrm{f}_{\mathrm{l}}\right)$ que contém posições estruturais (slots) para a propriedade $\left(\mathrm{f}_{\mathrm{m}}\right)$, o indivíduo $\left(\mathrm{x}_{\mathrm{j}}\right)$ e o lugar $\left(\mathrm{l}_{\mathrm{i}}\right)$.

Estados de coisas entram como a camada mais alta de organização e podem formar conjuntos tematicamente coerentes, os episódios, que, por sua vez, podem constituir a extensão de conteúdos proposicionais. Conteúdos proposicionais são construtos mentais sobre um (ou um conjunto de) estado de coisas. Episódios são hierarquicamente superiores a estados de coisas; conteúdos proposicionais são hierarquicamente superiores a episódios.

A recursividade no Nível Representacional pode acionar a inserção de construções encaixadas no Nível Morfossintático. Em termos de processo de complementação oracional, pode-se pensar que a recursividade no Nível Representacional é translinguística, enquanto o encaixamento, no Nível Morfossintático, não pode ser tratado senão como um caso específico de cada língua particular. É possível afirmar, assim, que a universalidade está no Representacional e a particularidade, no Morfossintático. A forma da completiva pode ter motivações semânticas, mas o modo como as expressões linguísticas são codificadas só aparece no Nível Morfossintático. Diferentes línguas podem, então, codificar diferentemente os tipos de encaixamento. A relação semântica é a mesma, mas é variável o tipo de construção sintática. A universalidade das línguas está no domínio funcional em que as motivações semânticas aparecem. Já os tipos morfossintáticos de encaixamento constituem um aspecto particular de cada língua e é apenas nesse nível que surgem as diferenças entre os sistemas 
linguísticos. No caso do português, postulo aqui que a expressão morfossintática não é arbitrária e formalmente autossuficiente ou autônoma, mas é o resultado, ao menos parcial, da atuação de princípios semânticos.

\subsection{O alinhamento na Gramática Discursivo-Funcional}

A noção de alinhamento desenvolvida pela GDF é extremante útil e teoricamente pertinente para tratar da relação que se estabelece entre o predicado encaixador e o tipo de oração completiva. A seleção do tipo de complemento depende da natureza das camadas interpessoal e representacional subjacentes. A codificação morfossintática reflete a estrutura definida pelas características semânticas da oração matriz, que determinam a natureza do predicado encaixado. Isso equivale a dizer que o alinhamento com o Nível Morfossintático é semântico, isto é, depende do tipo de predicado encaixador e de outras propriedades semânticas, como a correferencialidade entre participantes, portanto, depende do Nível Representacional.

$\mathrm{Na}$ GDF, o termo alinhamento é usado para designar o modo como as unidades pragmáticas e semânticas, não hierarquicamente relacionadas, são representadas nas unidades morfossintáticas. Muitas teorias recorrem às relações gramaticais, consideradas universais, para explicar o alinhamento; no entanto, na GDF, as relações gramaticais são também reconhecidas e formalizadas como funções sintáticas no Nível Morfossintático, mas não são assumidas como universais. As funções sintáticas são relevantes nos casos em que as propriedades formais das unidades linguísticas não podem reduzir-se a categorias pragmáticas e semânticas e a funções a elas subjacentes, ou seja, são relevantes quando há neutralização de distinções semânticas e pragmáticas. Nos casos em que não existe essa neutralização, assumese que as funções sintáticas estão presentes na representação morfossintática de uma oração. 
Dada sua organização, a GDF distingue três tipos básicos de alinhamento, o interpessoal, o representacional e o morfossintático. No alinhamento interpessoal, a estruturação morfossintática reflete a organização do Nível Interpessoal, seja em termos das funções pragmática (tópico, foco etc.) de subatos, ou em termos de sua referência (definitude, especificidade etc.).

No alinhamento representacional, a estruturação morfossintática reflete a organização do Nível Representacional, seja em termos das funções semânticas (Actor, Undergoer e Recipient) e categorias semânticas, ou em termos de sua designação (animacidade, pessoalidade etc.).

No alinhamento morfossintático, a estruturação morfossintática não é um reflexo direto da organização do Nível Interpessoal ou do Nível Representacional, mas apresenta sua própria organização em termos de funções sintáticas (sujeito, objeto) dos constituintes morfossintáticos ou em termos da complexidade (palavra, sintagma etc.) (cf. HENGEVELD; MACKENZIE, 2008). O reconhecimento de que, em alguns casos, o Nível Morfossintático não é motivado pelos níveis Interpessoal e Representacional alinha a GDF com as teorias funcionais não-radicais.

As línguas podem, então, ser classificadas de acordo com a organização da gramática de que dispõem, isto é, podem ser organizadas segundo princípios interpessoais, representacionais ou morfossintáticos. O que é certo é que se trata de tendências, já que, muitas vezes, as línguas podem exibir mistura de alinhamentos. Existem, por exemplo, línguas cujo alinhamento está sujeito tanto a fatores de referencialidade (fatores interpessoais) quanto a fatores de designação (fatores representacionais). Também há línguas em que a concordância verbal está sujeita a fatores representacionais, enquanto a elipse nas orações subordinadas está sujeita a fatores morfossintáticos. 
Na investigação desenvolvida neste trabalho, interessa o alinhamento representacional. Como mencionado anteriormente, as camadas do alinhamento representacional podem ser sensíveis a funções semânticas ou a mecanismos de designação. Uma língua em que o alinhamento é altamente sensível a funções semânticas é a língua indonésia acehnese ('achém'), que não dispõe da categoria de sujeito (cf. DURIE, 1985 apud HENGEVELD; MACKENZIE, 2008). Nessa língua, podem-se atribuir três funções semânticas aos argumentos dos predicados: Actor (A), Undergoer (U) e Recipient (R). ${ }^{56}$ Actor e Undergoer animados ocorrem como sintagmas nominais ou como pronomes clíticos ao verbo, formas em que podem ainda ocorrer simultaneamente. Os pronomes cuja função semântica é Actor são proclíticos e os que correspondem a Undergoer são enclíticos. É possível descrever esses fatos nessa língua sem recorrer às relações gramaticais. A expressão argumental é essencialmente organizada em termos das funções semânticas dos argumentos.

No exemplo em (3-19), a ocorrência da função semântica Actor provoca o uso do proclítico lôn; em (3-20), a função semântica Undergoer induz ao uso do enclítico geuh, e, em (3-21), tem-se um verbo com dois clíticos.

$$
\text { Lôn teungöh=lôn=jak. }
$$

$1 \quad$ centro $=1 . \mathrm{A}=\mathrm{ir}$

'I am going/ walking.'

'Eu estou indo/andando.'

$$
\begin{array}{ll}
\text { Gopnyan galak=geuh that } \\
\text { 3.POL feliz=3.POL.U muito }
\end{array}
$$

'He is very happy.'

\footnotetext{
${ }^{56}$ Actor (Ator) e Undergoer (Paciente) se referem, respectivamente, a argumentos de um estado de coisas dinâmicos com uma participação mais ativa e mais passiva. Como nem todos os estados de coisas são dinâmicos, a GDF faz distinção entre o dinâmico e o não-dinâmico, cuja principal característica é a ausência de um Actor. Locative (Locativo) tem a função de indicar o lugar de ocorrência do estado de coisas, seja ele dinâmico seja não-dinâmico. Nos estados de coisas dinâmicos, papéis locativos abrangem uma gama de distinções espaciais, a saber: ablativo (indicando a origem do movimento), perlativo (indicando o caminho do movimento), alativo (indicando o ponto final de circulação, e abrangendo outras distinções, como destinatário (Recipient), beneficiário, meta) (cf. HENGEVELD; MACKENZIE, 2008, p. 194-204).
} 
'Ele é muito feliz.'

(3-21) Gopnyan na=lôn=timbak=geuh

3.POL $\quad \mathrm{AUX}=1 . \mathrm{A}=$ disparar=3.POL.U

'I shot him.'

'Eu disparei nele.'

(Adaptado de HENGEVELD; MACKENZIE, 2008, p. 320)

Pode-se marcar a função semântica Actor com a preposição lê, como se vê em (3-22), e o Undergoer com a preposição keu. Observe-se que, como o Undergoer é inanimado, o verbo não dispõe de clítico. Como já mencionado, nessa língua, não existem formas clíticas que correspondam a Recipient.

(3-22) Keu=jih ka=geu=jôk buku=nyan lê=gopnyan.

$\mathbf{R}=3$. $\quad$ FAM INCH=3.POL. $A=$ dar $\quad$ livro=aquele $\quad \mathbf{A}=3 . P O L$

'He (polite) gave him (familiar) that book.'

'Ele (forma de cortesia) deu-lhe (forma informal) aquele livro.'

(Adaptado de HENGEVELD; MACKENZIE, 2008, p. 320)

O segundo tipo de alinhamento representacional é chamado de alinhamento hierárquico, já que sua organização é dependente das hierarquias de animacidade e pessoalidade. A língua dos aborígenes do Canadá, plains cree, exibe esse tipo de alinhamento (cf. WOLVENGREY, 2005 apud HENGEVELD; MACKENZIE, 2008).

(3-23) Ni-wîcih-â-nân-ak

1-ajudar-DIR-1.PL.3.PL

'We help them.'

'Nós ajudamos eles.' 


\section{(3-24) Ni-wîcih-iko-nân-ak \\ 1-ajudar-INV-1.PL.3.PL \\ 'They help us.' \\ 'Eles nos ajudam.'}

(Adaptado de HENGEVELD; MACKENZIE, 2008, p. 321)

Nos exemplos contidos em (3-23) e (3-24), os mesmos marcadores de pessoa são usados para a expressão do plural da primeira pessoa (o circunfixo ni ... nân) e da terceira pessoa (o sufixo -ak), independentemente das funções semânticas dos participantes (Actor e Undergoer, respectivamente). A codificação de tais orações obedece à hierarquia de pessoalidade, segundo a qual a segunda pessoa domina a primeira pessoa, e ambas dominam a terceira. Se a pessoa dotada de posição superior na hierarquia tiver a função semântica Actor, o verbo exibirá a chamada marcação direta (DIR), como em (3-23). Se a pessoa dotada de posição inferior na hierarquia tiver a função semântica de Actor, o verbo exibirá a marcação invertida (INV), como em (3-24).

Havendo dois argumentos da terceira pessoa, um deles receberá a marcação proximativa (PROX) e o outro a marcação obviativa (OBV). A terceira pessoa proximativa sempre domina a terceira pessoa obviativa. O resultado disso é que a interpretação das funções semântica dos participantes pode ser revertida por meio do sistema direto-inverso ou pelo sistema proximativo-obviativo. Os dois sistemas interagem, permitindo todas as combinações possíveis das funções pragmáticas e semânticas (cf. HENGEVELD; MACKENZIE, 2008), como ilustram os exemplos de (3-25) a (3-28).

$\begin{array}{lll}\text { (3-25) } & \text { Câniy- } \varnothing \quad k \hat{\imath}-w \hat{\imath} c i h-\hat{e}-w & \text { Mêrî-wa. } \\ \text { João-PROX } \quad \text { TNS-ajudar-DIR-3 } & \text { Maria-OBV } \\ \text { 'Johnny helped Mary' } & \\ \text { 'O João, ele ajudou a Maria.' } & \end{array}$


Câniy-wa kî-wîcih-ê-w Mêrî-

João-OBV TNS-ajudar-DIR-3 Maria-PROX

'Mary helped Johnny.'

'A Maria, ela ajudou o João.'

Câniy-Ø kî-wîcih-ikw(-w) Mêrî-wa.

João-PROX TNS-ajudar-INV-3 Maria-OBV

'Mary helped Johnny.'

'O João, a Maria ajudou.'

Câniy-wa kî-wîcih-ikw(-w) Mêrî- $\varnothing$.

João-OBV TNS-ajudar-INV-3 Maria-PROX

'Johnny helped Mary.'

'A Maria, o João ajudou.'

(Adaptado de HENGEVELD; MACKENZIE, 2008, p. 322)

Lançando mão desses fatos, neste trabalho, postulo que a noção de alinhamento hierárquico, limitado à designação de categorias, estenda-se à designação de eventos, de modo a levar em consideração a integração semântica no tratamento das relações estabelecidas entre o tipo de predicado encaixador e o tipo de complemento requerido.

\subsection{A subordinação na Gramática Discursivo-Funcional}

Muitos estudos desenvolvidos sob a égide da GF tratam do fenômeno da complementação. Reconhece-se, na teoria da GF, que predicações, proposições e atos de fala, que compõem a estrutura de orações simples, podem aparecer também na forma de orações subordinadas, encaixadas na posição de argumento de predicados.

Hengeveld (1989), valendo-se das considerações de Foley e Van Valin (1984) e de Lehmann (1988), entende que as orações subordinadas podem classificar-se de acordo com a camada mais alta que as contém. O tratamento da subordinação a partir das camadas de 
representação também é sustentado por Dik e Hengeveld (1991), Hengeveld (1990a, 1990b), Bolkestein (1990, 1992) e Dik (1997b), em termos de unidades semântico-funcionais. Essas unidades, originalmente consideradas pela teoria standard, continuam a vigorar no novo modelo, mas, como se mostrará a seguir, outras unidades de análise são inseridas.

Nas diferentes línguas, as orações subordinadas podem divergir entre si no que tange às propriedades formais. O português, por exemplo, dispõe de diferentes tipos de completivas para assinalar a relação de complementação, desde construções plenamente finitas, como em (3-29), a encaixadas com propriedades nominais, como em (3-30). O quéchua e o turco, por sua vez, não dispõem de construções completivas finitas no processo de complementação, valendo-se, para tanto, de construções não-finitas.

Alfredo quer que Ana se case com Alessandro.

(3-30) Alfredo quer o casamento de Ana com Alessandro.

As orações subordinadas podem também divergir da oração matriz. No exemplo do inglês em (3-31), a completiva, por si só, é idêntica à oração matriz, não há nenhum complementizador marcando a relação de subordinação de uma em relação à outra.

\section{Perry knows Hugh is vulnerable ${ }^{57}$}

Há, entretanto, línguas em que orações completivas diferem da principal. Essas diferenças dizem respeito à ausência ou presença (i) de complementizadores, (ii) de formas verbais especiais e (iii) de marcas especiais de argumentos (cf. HENGEVELD; MACKENZIE, 2008).

Noonan (1985) entende por complementizador uma palavra, partícula, ou afixo com a função de identificar uma entidade como complemento. Há línguas em que esses

\footnotetext{
${ }^{57}$ Exemplo retirado de Noonan (1985, p. 45). De acordo com Noonan, o uso de complementizador com alguns tipos de complementos é, algumas vezes, opcional ou contextualmente determinado. A construção em (3-31) também seria possível, segundo o autor, com o complementizador (Perry knows that Hugh is vulnerable).
} 
complementizadores assinalam tanto a relação de subordinação quanto a expressão de um novo significado, como ocorre, por exemplo, com os complementizadores que/se e que/si, do português e do espanhol, respectivamente.

(3-32)a. Alfredo não sabe que Ana viajará logo.

b. Alfredo não sabe se Ana viajará logo.

(3-33)a. Alfredo no sabe que Ana viajará pronto.

b. Alfredo no sabe si Ana viajará pronto.

As completivas do português e do espanhol dadas em (3-32a-b) e (3-33a-b), respectivamente, diferem da oração matriz pela presença de uma conjunção na primeira posição. Braga (2008) salienta que, no português, o complementizador sempre ocupa a primeira posição na oração subordinada, que, por sua vez, preserva a mesma ordem com que os constituintes aparecem na oração matriz. Essa característica da língua portuguesa a difere, por exemplo, do checo, cujos complementizadores aparecem na segunda posição, como exemplifica (3-34), e do holandês, que pode ter os constituintes da oração subordinada (335b) dispostos em uma ordem diferente daquela que ocorre na oração matriz (3-35a):

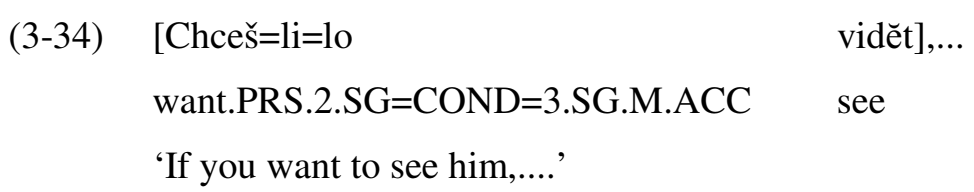

(3-35)a. Ik heb gisteren het boek an het meisje gegeven
I have .PRS.1.SG yesterday DEF book to DEF girl give.PTCP
'I gave the book to the girl yesterday.'
b. dat ik gisteren het boek aan het meisje heb girl have.PRS.1.SG give.PTCP
CONJ I.NOMT yesterday DEF book to DEF girl
'that I gave the book to the girl yesterday'


No que diz respeito à ausência ou presença de formas verbais especiais de subordinadas, mais especificamente, de completivas, basta dizer, por enquanto, que a seleção do tipo de oração completiva está diretamente ligada ao tipo semântico do predicado encaixador e à camada de representação, no Nível Representacional. Os exemplos em (3-36af) ilustram os tipos de completivas aqui considerados:

(3-36)a. Ana disse que Alfredo viajará em breve.

b. Alfredo ordenou que Ana saísse da sala de reuniões.

c. Ana quer que Alfredo mude de emprego.

d. Alfredo viu dois funcionários entrarem atrasados.

e. Ana quer mudar de emprego.

f. Alfredo assinou a demissão de Ana com satisfação.

Ainda em relação às diferenças possíveis entre orações subordinadas e respectivas matrizes, cabe mencionar a terceira propriedade, que diz respeito aos argumentos da construção subordinada, o de poderem ou não ser realizados. Tratando especificamente da complementação do português, há casos em que, para a ocorrência de completivas mais nominais com determinado tipo de predicado encaixador, é obrigatória a correferência entre o argumento da oração principal e o argumento da subordinada, como ocorre com o predicado querer em (3-36e), em que o sujeito, correferencial, não vem realizado.

As línguas podem ter mais de um modelo disponível para a expressão de orações subordinadas. Uma questão importante que se coloca, assim, é de que forma se dá a seleção entre esses diferentes modelos. Como apresentado na seção anterior, na proposta da GDF, a gramática está disposta em níveis, que dão conta de motivações pragmáticas e de motivações semânticas, e os níveis estão dispostos em camadas hierarquicamente organizadas. Para a GDF, as construções subordinadas podem classificar-se de acordo com as camadas dos Níveis Interpessoal e Representacional que subjazem a elas (cf. HENGEVELD 1989, 1998; 
HENGEVELD; MACKENZIE, 2008). Na complementação, a semântica do predicado encaixador de complemento determina que tipo de unidade interpessoal ou representacional funcionará como um predicado dependente.

Hengeveld e Mackenzie (2008) fornecem uma classificação de orações completivas que toma a função ou significado do predicado encaixador de complemento como ponto de partida, como mostra o quadro 3-3. Nessa classificação, os autores assumem que o predicado encaixado pode ser desde um move, no Nível Interpessoal, até uma propriedade, no Nível Representacional. Os complementos são, assim, analisados em termos de função e de significado. De qualquer modo, tudo depende das propriedades de designação, isto é, das características semânticas do predicado encaixador, e são elas que determinam o que vem encaixado. $^{58}$

\begin{tabular}{|ll|}
\hline \multicolumn{1}{|c}{ Tipo de oração } & Função/Significado do Predicado encaixador de complemento \\
Move & Situar um move no discurso mais amplo \\
Ato & Relacionar Atos Discursivos entre si \\
Conteúdo comunicado & Transmissão e recepção de Conteúdo Comunicado \\
Conteúdo proposicional & Atitude proposicional, Inferência \\
Episódio & Situar um Episódio em relação a outro \\
Estado de coisas & Percepção direta, Volição \\
Propriedade Configuracional & Aspecto, Modalidade orientada para o participante \\
\hline
\end{tabular}

Quadro 3-3: Classificação de orações completivas (HENGEVELD; MACKENZIE, 2008, p. 363)

Tendo em vista a distinção dos tipos de complementos de acordo com o nível e camada em que ocorrem, no Nível Interpessoal tem-se:

\footnotetext{
58 As propriedades compreendidas na designação são basicamente as funções semânticas dos argumentos. Entretanto, Dik (1997a) postula, com outros linguistas, uma tipologia semântica de predicados que, por direito, são mecanismos de representação semântica, ou designação.
} 
(a) M-complemento: são orações que funcionam como complemento de predicados que introduzem moves, como em (3-37). ${ }^{59}$ Esses complementos podem ser modificados por modificadores que atuam na camada de moves, como, por exemplo, 'para resumir', 'para concluir', 'em resumo', 'em suma'.

(3-37) Embora seja difícil fazer generalizações sobre um público tão diverso, é fácil concluir [que, em suma, essas ações levaram a uma perda líquida da cobertura vegetal em relação às condições pré-colonização, bem como a uma mudança substancial no tipo da atual vegetação. Ao mesmo tempo, a consciência pública concernente à importância da vegetação urbana certamente tem aumentado nos últimos dez anos, embora seja uma questão aberta quanto daquela conscientização traduziu-se em mudança de comportamento em comparação com as áreas urbanas plantadas em Quito. $]^{60}$

(b) A-complemento: são orações que funcionam como complemento de predicados que introduzem atos discursivos, como em (3-38). Atos discursivos podem ser modificados por elementos lexicais variados, que incidem sobre suas propriedades estilísticas, como brevemente, ou sobre seu estatuto dentro do move, como a expressão além disso.

(3-38) Desnecessário dizer que, além disso, aspectos como quantidade e foco no cliente devem ser sempre lembrados. ${ }^{61}$

(c) C-complemento: são orações que funcionam como complemento de predicados que introduzem um conteúdo comunicado, como em (3-39). O conteúdo comunicado compreende a totalidade do que o falante evoca em sua comunicação com o ouvinte. Pode ser modificado por material lexical relacionado à ênfase, como realmente, ou por modificadores que expressam a atitude subjetiva do falante em relação ao conteúdo comunicado, como, por

\footnotetext{
${ }^{59}$ Vale lembrar que move é a unidade máxima do Nível Interpessoal e propriedades, juntamente com entidades, as unidades do Nível Representacional.

${ }^{60}$ Exemplo retirado de Hengeveld e Mackenzie (2008, p.364). Cf o original: While it is difficult to make generalizations about such a diverse public, it is easy to conclude [that, in sum these actions have led to a net loss of vegetative cover relative to pre-settlement conditions, as well as a substantial change in the type of vegetation present. At the same time, public consciousness regarding the importance of urban vegetation has certainly risen in the last ten years, although how much of that awareness has translated into changed behavior vis a vis urban plants in Quito is an open question.]

${ }^{61}$ Exemplo retirado de Hengeveld e Mackenzie (2008, p.364). Cf o original: It goes without saying that (in addition) issues such as quality and a customer-oriented approach will be kept in mind.
} 
exemplo, (in)felizmente e os reportativos, segundo, de acordo com, que indicam que o falante transmite um conteúdo comunicado que foi expresso por outros.

(3-39) Marta disse que (realmente) não acredita em vitória no primeiro turno das eleições.

A GDF considera que existe nos moves, atos discursivos e conteúdos comunicativos encaixados um elemento de força ilocucionária. Depois de é fácil concluir que, na ocorrência em (3-37), por exemplo, encontra-se a informação crucial que o autor quer comunicar aos leitores. Segundo Mackenzie (comunicação pessoal), o teste de assertividade, sugerido por Cristofaro (2003), é perfeitamente aplicável: It is easy to conclude that these actions have led to a net loss, haven't they? It goes without saying that issues such as quality will be kept in mind, won't they?

Segundo Mackenzie (comunicação pessoal), nos exemplos de (3-37) a (3-39), o predicado encaixador é, do ponto de vista pragmático, comunicativamente inferior à cláusula encaixada:

É fácil concluir que $X=$ Em conclusão, $X$ obviamente $\ldots$

É desnecessário dizer que $X=X$ claramente $\ldots$

Marta disse que $X=$ Segundo ela, $X \ldots$

No Nível Representacional, Hengeveld e Mackenzie (2008) distinguem os seguintes tipos de complementos:

(d) p-complemento: são orações que funcionam como complemento de predicados que introduzem uma proposição, como em (3-40). Os modificadores que atuam nessa camada ou especificam as atitudes proposicionais (como, por exemplo, provavelmente, evidentemente) ou especificam vagamente a fonte do conteúdo proposicional (como, por exemplo, presumivelmente, supostamente). 
(3-40) Ana acredita que (provavelmente) visitará Cuba em setembro.

(e) ep-complemento: são orações que funcionam como complemento de predicados que sinalizam a introdução de um episódio, como em (3-41). Episódios podem ser especificados por meio de modificadores e operadores que servem a sua localização no tempo, como, por exemplo, depois.

(3-41) E sucedeu que, pela meia noite, (depois de acordar) o homem estremeceu e se voltou; e eis que uma mulher jazia a seus pés

(Adaptado de BRAGA, 2008, p. 23)

(f) e-complemento: são orações que funcionam como complemento de predicados que introduzem estado de coisas, como em (3-42). As modificações nessa camada de representação concernem ao tempo de ocorrência, o lugar de ocorrência, a frequência de ocorrência, o estatuto de realidade, o contexto físico e o cognitivo.

(3-42) Ana quer retornar a Cuba (em breve).

(g) f-complemento: são orações que funcionam como complemento de predicados que introduzem propriedades configuracionais, como em (3-43). Esses complementos podem ser modificados por modificadores que escopam a camada representacional.

(3-43) O motorista embriagado continuou a correr (perigosamente) na contramão da rua.

Segundo Hengeveld e Mackenzie (2008), essa abordagem não somente considera que modificadores e operadores expressos em oração completiva são determinados pelo tipo da oração, como também fornece meios para considerar as diferenças na forma e no comportamento do complemento. Hengeveld $(1989,1998)$ sustenta que é possível explicar as diferenças na forma de expressão das orações subordinadas em termos de diferenças interpessoal e representacional subjacentes. Isso significa dizer que a seleção do tipo de 
oração complemento depende da natureza das camadas interpessoal e representacional subjacentes a essa oração.

Numa perspectiva translinguística, uma generalização que se pode fazer é que, quanto mais baixo o nível em que uma oração subordinada se baseia, maior é a probabilidade de ela ser do tipo dessentencializado ('deranked' [STASSEN, 1985]), isto é, não exibir marcas gramaticais associadas aos membros mais prototípicos das orações. ${ }^{62}$ A dessentencialização é a contraparte formal da redução do número de operadores primários a serem morfossintaticamente expressos e pode, portanto, ocorrer em diferentes graus. Há línguas, por exemplo, em que as orações completivas são dessentencializadas no sentido de que o marcador declarativo não pode ser expresso nela e seu estatuto de subordinada é marcado por uma conjunção; no entanto, esse tipo de oração completiva é menos dessentencializado do que nominalizações, já que tempo e aspecto podem ser expressos nela, algo impossível de ser expresso em nominalizações.

\section{- Breve recapitulação}

O capítulo anterior apresentou os suportes teóricos de cunho funcionalista que trazem contribuições significativas para este trabalho e para o estudo da complementação em geral. Considerada o arcabouço teórico principal para a investigação aqui proposta, este capítulo focalizou os aspectos gerais da GDF (HENGEVELD; MACKENZIE, 2008), salientando as partes relevantes para o estudo da subordinação completiva, sobretudo em termos da caracterização geral do modelo da GDF, da categoria semântica da unidade linguística e da noção de alinhamento. Apresentou também o tratamento que a GDF dispensa à subordinação,

\footnotetext{
${ }^{62}$ Um tipo dessentencializado de construção completiva é aquele em que não há manifestação de propriedades oracionais típicas, como núcleo verbal, força ilocucionária, complementizador e flexão modo-temporal (LEHMANN, 1988).
} 
mostrando como as estruturas completivas são descritas nesse modelo, especificamente no que tange à caracterização dos predicados encaixadores de complemento.

Com este capítulo, encerra-se a parte destinada à definição dos aspectos diversos do posicionamento teórico. No capítulo seguinte, apresento o universo de pesquisa e os procedimentos metodológicos e, no Capítulo 5, procedo à análise empírica dos tipos de orações completivas dentro do enfoque escolhido, o da GDF, na tentativa de mostrar que quanto mais baixa a camada de representação do complemento tanto maior o grau de integração semântica entre o predicado da oração encaixadora e o predicado da oração completiva. Os aspectos teóricos e empíricos serão retomados no Capítulo 6, que trata das generalizações e implicações teóricas. 
PARTE II:

ANÁLISE DA COMPLEMENTAÇÃO NO

PORTUGUÊS FALADO 


\section{CAPÍTULO 4}

\section{UNIVERSO DE PESQUISA E PROCEDIMENTOS METODOLÓGICOS}

\subsection{Considerações iniciais}

Este capítulo é um relato do aparato metodológico e do universo de pesquisa utilizados para o desenvolvimento da análise de dados. Como a análise a ser apresentada no próximo capítulo é feita com base num corpus de língua falada, na seção 4.2, apresentam-se algumas considerações sobre o uso de corpora na investigação linguística e de resultados obtidos a partir da frequência de dados. Nas seções seguintes, explicitam-se (4.3) o corpus de investigação, (4.4) os procedimentos metodológicos essenciais à realização da pesquisa, que considera os diferentes tipos de complementação, dentre os quais se destacam os grupos de fatores e o levantamento quantitativo dos dados, e (4.5) as hipóteses de trabalho.

\subsection{Considerações sobre metodologia de trabalho: corpus e frequência}

Antes de qualquer consideração a respeito da metodologia utilizada, é necessário partir do fato de que, como demonstrado ao longo deste trabalho, a perspectiva de pesquisa adotada é funcionalista e tem como base teórica a GDF (HENGEVELD; MACKENZIE, 2008). O princípio central do funcionalismo é o de que a língua é, acima de tudo, uma forma de comunicação humana em um contexto sociocultural e psicológico e esse fato pode determinar a perspectiva de como a língua pode ser modelada. Como se sabe, um dos pontos em que a teoria gerativa e funcionalismo se distinguem é a concepção de linguagem: o modo como os gerativistas a concebem, como conhecimento internalizado, os obriga a tratar metodologicamente da competência mediante esse conhecimento, que são as intuições do falante-ouvinte. 
$O$ fato de, na concepção funcionalista, a linguagem ser um instrumento de comunicação faz com que ela leve em conta a evidência que sobressai da linguagem em uso que os corpora tornam disponível (BUTLER, 2004). Isso parece verdadeiro por princípio. No entanto, se se considera a escala proposta por Butler (2008), que coloca os formalistas num extremo e o funcionalismo da Costa Oeste Americana no outro, observa-se que nem toda a corrente funcionalista leva em conta a linguagem em uso. ${ }^{63} \mathrm{O}$ extremo mais radical do espectro assume um compromisso particular com o estudo de produções linguísticas autênticas. Como parte de uma ampla teoria de interação verbal, a GDF ocupa uma posição intermediária entre abordagens radicalmente funcionalistas e radicalmente formalistas, para a qual os julgamentos introspectivos do falante exercem um papel na descrição e na teorização linguística, somente porque a evidência que sobressai dos corpora ainda precisa ser interpretada (cf. BUTLER, 2004).

Sobre a perspectiva funcional, chamam atenção as observações de Sinclair (1991 apud BUTLER, 2004, p. 148), para quem (i) deve-se estar aberto a padrões quantitativamente observáveis na língua e (ii) a língua reserva uma riqueza de padrões significativos. Parece não haver incompatibilidade entre procurar padrões significativos que emergem de um tratamento de corpora e ter, de antemão, hipóteses prévias que apontem os caminhos possíveis de serem seguidos no tratamento dos dados.

Ao se lidar com corpora, há duas alternativas: é possível olhar para um domínio funcional como se tudo nele fosse novo e observar, no corpus, como esse domínio funcional aparece codificado; alternativamente, com base num arcabouço teórico, é possível levantar algumas categorias analíticas e, a partir do corpus, observar se as hipóteses que estão por trás da distribuição dessas categorias se confirmam ou não. Nesse caso, as categorias de análise já

\footnotetext{
${ }^{63}$ Cf. Capítulo 1, seção 1.5, p. 49.
} 
estão previstas, e o corpus é o lugar em que elas devem manifestar-se, como uma forma de contornar os problemas de intuição.

A análise apresentada neste trabalho parte de um corpus de língua falada. Sobre isso, é interessante a distinção que Butler (2004) faz entre dois diferentes enfoques para o uso de corpus, baseando-se em Tognini-Bonelli (2001 apud BUTLER, 2004, p. 153). O enfoque baseado em corpus (corpus-based) se refere a uma metodologia que se beneficia do corpus principalmente para interpretar, testar ou exemplificar teorias e descrições que já foram formuladas antes de grandes corpora se tornarem disponíveis ao estudo linguístico. Em um enfoque dirigido por corpus (corpus-driven), o compromisso do linguista é com a integridade dos dados como um todo, e as descrições abrangem as evidências do corpus. Desse modo, o corpus é mais do que um 'depósito' de exemplos que apóia as teorias pré-existentes. As demonstrações teóricas são totalmente consistente com o corpus e refletem diretamente as provas fornecidas por ele.

A distinção entre as duas diferentes perspectivas permite enquadrar este trabalho no enfoque baseado em corpus, porque, aqui, a análise de uma amostra tem o intuito de fornecer probabilidades para a ocorrência de determinados tipos de construções. Parte-se de uma perspectiva teórica e, a partir do corpus, observa-se se podem ser validadas as hipóteses que estão por trás da distribuição das categorias investigadas.

Considerando-se que este trabalho se insere no quadro de pesquisas que utilizam corpora para a explicação dos fenômenos sob investigação, pode-se pensar que todas as ocorrências possíveis sobrevêm do corpus, daí ser subjetivo demais testar as possibilidades com a intuição. Deve haver alguma razão para a sociolinguística laboviana e a teoria funcionalista em geral, principalmente a norte-americana, acharem que os dados reais de conversação são necessários. 
Labov (1972) considera que o que as pessoas pensam sobre a forma da linguagem, isto é, a intuição, ou conhecimento internalizado de que dispõem, está muito distante do modo como realmente falam. Fornece, então, exemplos decisivos sobre quantificação para criticar o princípio de que só a competência do falante-ouvinte resolve todos os problemas de análise da estrutura da língua. Se, por um lado, Labov critica o apego dos gerativistas às intuições, alegando que ir aos dados reais dá um grau muito maior de certeza da adequação da relação entre teoria e dados, por outro, o problema com esse método é o de não encontrar uma construção que a intuição do falante-ouvinte diz que existe.

Um problema natural com que se depara quem trabalha com dados reais de fala em situações reais de interação é a possibilidade de não aparecerem todos os tipos de construções possíveis; no caso específico deste trabalho, é a possibilidade de não figurarem no continuum de encaixamento complementos possíveis, seja como construções alternativas, sugerindo escolha pelo falante, seja como construções únicas, sugerindo imposição ao falante. $\mathrm{O}$ procedimento metodológico mais eficaz, para superar esse tipo de limitação próprio de dados emanados de corpora, é misturar o levantamento de dados com a construção de exemplos baseados na intuição. Assim, embora o material de análise seja constituído por ocorrências levantadas nos inquéritos, conforme será apresentado na próxima seção, a análise qualitativa dos dados vale-se do conhecimento intuitivo para completar o continuum com as outras construções disponíveis e devidamente licenciadas pela gramática da língua portuguesa em dependência dos processos semânticos envolvidos. ${ }^{64} \mathrm{O}$ conhecimento intuitivo aparece, na análise dos dados, substituído por construções retiradas da internet, para preservar ao máximo a máxima funcionalista de lidar com dados reais; fica para a intuição propriamente dita apenas

\footnotetext{
${ }^{64}$ Para os propósitos deste trabalho, quantitativamente, o que a frequência tem a dizer é sobre as preferências do falante no uso. Constitui, assim, uma ferramenta para a discussão sobre o fenômeno estudado, e, embora possa não ser algo determinante, não deve ser descartada. As gramáticas fornecem os mecanismos de codificação mais econômicos para as funções do discurso que os falantes necessitam executar mais frequentemente, ou, mais sucintamente, as gramáticas codificam melhor o que os falantes fazem mais (DU BOIS, 1985).
} 
a construção de dados que podem representar formas alternativas de complementação que a gramática do português admite codificar.

\subsection{Delimitação do corpus}

O universo da investigação é composto por uma amostragem extraída do Banco de Dados Iboruna, que registra uma variedade do português brasileiro ainda pouco explorado: o português falado numa parte da região noroeste do interior paulista, nucleada em torno da cidade de São José do Rio Preto. ${ }^{65}$ Além desse traço, devem-se considerar também os seguintes aspectos:

(i) controla variáveis estratificadas como sexo, escolaridade, faixa etária e nível sócioeconômico, e variáveis não-estratificadas, como a localização geográfica dos informantes (provenientes de sete cidades circunvizinhas da região);

(ii) dispõe de um conjunto de dados mais recentes, com entrevistas realizadas em 2004;

(iii) apresenta cinco tipos diferentes de textos: narrativa de experiência pessoal, narrativa recontada, relato de opinião, relato de procedimento e relato de descrição;

(iv) o aproveitamento deste corpus alinha este trabalho com um dos objetivos do Grupo de Pesquisa em Gramática Funcional, que é o de debruçar-se sobre a variedade dialetal da região de São José do Rio Preto.

O material de análise contém 346 ocorrências de construções encaixadas completivas, que serão analisadas de acordo com os critérios estabelecidos no item 4.4. Do IBORUNA, foram selecionados 43 inquéritos, com dois diferentes tipos de amostra: uma amostra do censo

\footnotetext{
${ }^{65}$ Para maiores detalhes sobre o Banco de Dados Iboruna, consultar Gonçalves e Tenani (2008), que tratam dos procedimentos metodológicos que nortearam os trabalhos de transcrição das amostras de fala do Projeto ALIP (Amostra Lingüística do Interior Paulista). Esse projeto, idealizado pelo Grupo de Pesquisa em Gramática Funcional da UNESP de São José do Rio Preto e financiado pela Fundação de Amparo à Pesquisa do Estado de São Paulo - FAPESP (Proc. 03/08058-6) de 2004 a 2007, permitiu a constituição de um banco de dados com amostras do português falado na região noroeste do Estado de São Paulo, delimitada pela cidade de São José do Rio Preto e mais seis cidades fronteiriças a ela (cf. GONÇALVES; TENANI, 2008).
} 
linguístico da região de São José do Rio Preto (AC), com o controle rigoroso de variáveis sociais, constituída de 36 inquéritos, e uma amostra de interação dialógica (AI), constituída de 07 inquéritos. $^{66}$

\subsection{Procedimentos metodológicos e técnicas de investigação}

Para a seleção das ocorrências que constituem o material de análise deste trabalho, considerei (i) construções encaixadas completivas finitas, ou seja, orações completivas cujo verbo está em uma de suas formas desenvolvidas (a) no indicativo ou (b) no subjuntivo, e é introduzida por que ou se; (ii) construções encaixadas não-finitas, caso em que a oração completiva tem como núcleo ou (c) um infinitivo pessoal, ou (d) um infinitivo impessoal, ou (e) uma nominalização (que consiste numa construção que se aproxima das características de um membro prototípico da classe dos nomes).

O critério para o levantamento da amostra consistiu, desse modo, na seleção de orações completivas segundo uma hierarquia com cinco distinções, que mostra o grau de sentencialidade/nominalidade (cf. NOONAN,1985; LEHMANN, 1988; GIVÓN, 1980):

(4-1) Grau de sentencialidade/nominalidade

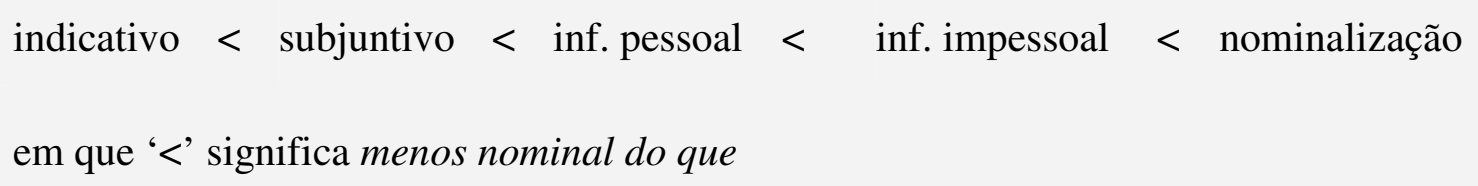

Embora o gerúndio constitua um tipo de oração não-finita, juntamente com o particípio (cf. NOONAN, 1985; KOPTJEVSKAJA-TAMM, 1993; DIK, 1997b), ele não foi considerado na amostra analisada. O que difere uma construção como eu vi Maria cantar de

\footnotetext{
${ }^{66}$ A amostra do censo linguístico diz respeito aos inquéritos 004, 008, 012, 016, 020, 024, 031, 035, 039, 043, 047, 051, 062, 067, 071, 076, 080, 084, 088, 092, 096, 100, 104, 108, 112, 116, 120, 124, 128, 132, 134, 141, 145, 149, 152; a amostra de interação dialógica corresponde aos inquéritos 001, 002, 004, 005, 006, $007,008$.
} 
eu vi Maria cantando é o aspecto progressivo que aparece em Maria cantando. Como um marcador de aspecto, usado para exprimir uma circunstância, construções com gerúndio não são relevantes para a análise proposta neste trabalho.

Cabe explicar que, no que diz respeito às orações completivas finitas selecionadas para a análise, a amostragem desse tipo de construção abrangeu as orações introduzidas por que e por se, considerados complementizadores em vários estudos sobre complementação oracional (CRISTOFARO, 2003; DIK, 1997b; LANGACKER, 1991; NOONAN, 1985; RANSON, 1986 apud FRAJZYNGIER, 1996; GIVÓN, 1980).

Orações introduzidas por que e se se diferenciam em alguns aspectos: a conjunção $s e$, diferentemente de que, introduz complementos oracionais correspondentes a uma interrogativa polar indireta e tem forma idêntica à conjunção que introduz oração adverbial condicional. Além disso, diferentemente dos complementos com que, o valor de verdade dos complementos oracionais introduzidos por se é hipotético e, portanto, não se define e nem pode ser pressuposto como factual/não-factual. Essa característica dos complementos iniciados por se, ligada à expressão da modalidade irrealis que neles se encontra, permite considerar por que a complementação com se se restringe a determinados tipos de predicados que admitem um complemento iniciado por que (cf. SOUSA, 2007).

Muitos trabalhos que tratam da complementação tomam os complementos finitos introduzidos por que como o fenômeno a ser estudado, entretanto, salvas as diferenças entre os dois tipos de complementizadores, há predicados encaixadores que somente admitem a partícula se como partícula introdutora de complemento, como, por exemplo, verbos como perguntar, indagar etc. Por essas razões, muito embora o complementizador que seja tratado em alguns estudos como o exemplar mais característico da categoria, optei por incluir as orações introduzidas por se na amostragem extraída para análise.

No que diz respeito às nominalizações, a seleção desse tipo de construção para o 
trabalho comparativo inclui os predicados que contêm a estrutura transitiva típica constituída dos argumentos sujeito (nominativo) e objeto (acusativo) e os predicados de outros tipos semânticos, como os estativos com experienciador (Undergoer), que dispõem de complementos oblíquos, como preocupar-se com; nos nominais de ação, ambos os argumentos podem assumir a expressão de possuidor no processo de nominalização lexical; já em predicados com oblíquo, as nominalizações herdam o objeto no mesmo caso que o do predicado input, isto é, visibilizado pela preposição, como em a preocupação de Maria com a inflação.

Não foram selecionados complementos de verbo-suporte, como ter e dar, por exemplo, visto que esses complementos (orações não-finitas com infinitivo e com nominalização) não podem ser considerados como um tipo de construção encaixada por funcionar como uma lexia composta, já que o falante não seleciona o verbo e o complemento separadamente.

Após proceder à investigação teórica e tendo definido acima o corpus da pesquisa, o passo subsequente para a investigação empírica das orações completivas do português brasileiro foi a definição de um conjunto de critérios para a análise das ocorrências encontradas no corpus.

A vocação naturalmente empírica deste trabalho implica a necessidade de levantamento quantitativo, com especial relevância para frequências percentuais que indicam correlação entre fatores de análise sob o prisma das construções encaixadas e a natureza semântica do predicado encaixador. Para o processamento dos dados, empreguei alguns programas do pacote estatístico VARBRUL - Variable Rule Program (SANKOFF, 1975), idealizado pela sociolinguística quantitativa, para a análise de fenômenos variáveis, que foram capazes de fornecer apenas as frequências necessárias para o estabelecimento de correlações mais relevantes. 


\subsection{Hipóteses do trabalho}

Nesta seção, apresento as hipóteses de trabalho. Os critérios de análise apresentados aqui são abertos, ou seja, não conduzem as hipóteses a serem comprovadas ou rejeitadas na interpretação dos dados. Para a verificação do fenômeno sob estudo, parti de um arcabouço teórico e, com base nele e no conhecimento prévio sobre as relações de complementação, levantei hipóteses para a explicação do comportamento de orações completivas em relação ao predicado encaixador. Essas hipóteses podem se confirmar ou não, dependendo dos resultados obtidos a partir da análise da amostra. Esse é o papel que as hipóteses aqui apresentadas exercem sobre os dados analisados.

\section{- Hipótese 1}

Uma hipótese crucial para os objetivos desta pesquisa é a de que a semântica do predicado encaixador de completivas é altamente relevante para determinar a categoria morfossintática das predicações dependentes. Em outros termos, suspeita-se de que a relação de gradação entre construções nominais com verbo finito e construções nominais com grau máximo de nominalidade, na complementação do português brasileiro, depende estritamente da categoria semântica do predicado encaixador.

O procedimento metodológico que pode fornecer evidências empíricas para a comprovação ou não dessa hipótese se circunscreve aos seguintes parâmetros:

(i) exame das formas de cada oração dependente, aqui restritas aos seguintes tipos: (a) oração introduzida por complementizador, isto é, forma conjuncional com verbo finito, (b) orações com redução de finitude, que se identificam nas construções não-finitas que têm um infinitivo como predicado nuclear e (c) construções não-finitas com uma nominalização como predicado nuclear, forma que identifica o grau máximo de dessentencialização, nos termos de Lehmann (1988). Como é natural haver uma inconsistência entre o sistema gramatical 
compreendido pela competência gramatical do falante e as preferências de uso baseadas na competência comunicativa, não é suficiente verificar, no corpus, a natureza formal das construções encaixadas como evidência da expressão morfossintática da dependente em relação à natureza semântica da matriz. É necessário verificar, para cada ocorrência ou token, a natureza type da construção, o que o domínio funcional do predicado encaixador e o conjunto das possibilidades formais alternativas de oração dependente admitem.

(ii) análise da natureza semântica do predicado encaixador, de acordo com os parâmetros de classificação fornecidos por Dixon (2006), complementado por Dik (1997b), Cristofaro (2003) e Noonan (1985). Esses tipos de classificação prevêem uma correlação entre uma hierarquia semântica de manipulação progressiva, que identifica o predicado da matriz, e uma hierarquia sintática na forma da predicação dependente, que, conforme identificado em (i), assume a forma de verbo finito a predicado plenamente lexicalizado como nome.

Embora se reconheça uma relação de reciprocidade entre os parâmetros incluídos em (i) e (ii), no tratamento quantitativo eles são vistos como três diferentes grupos de fatores, definidos abaixo como grupos de fatores 1, 2, para a forma de expressão, e 3 para a natureza semântica do predicado encaixador.

Grupo de Fatores 1 - Tipos de complementação: forma da oração completiva
a) oração finita com indicativo
b) oração finita com subjuntivo
c) oração não-finita com infinitivo pessoal
d) oração não-finita com infinitivo impessoal
e) oração não-finita com nominalização 
O grupo de fatores 1 é, por assim dizer, definido como variável dependente em relação aos demais grupos de fatores, já que, por identificar a codificação morfossintática das completivas, é considerado como motivado pelos grupos de fatores semânticos.

Tal como apresentado no início desta seção, para a seleção dos tipos de complementação, considerei a escala de variação entre construções encaixadas verbais e nominais: num extremo, construções completamente verbais, isto é, orações que têm as propriedades de uma oração principal (4-2a); construções intermediárias na escala gradativa, ou seja, orações mais dependentes, como (4-2b), e não-finitas com um verbo infinitivo pessoal (4-2c) e impessoal (4-2d) como núcleo; finalmente, no outro extremo, orações nãofinitas com uma nominalização como núcleo (4-2e), isto é, construções que não apresentam propriedades sentenciais típicas, como núcleo verbal, força ilocucionária, complementizador e flexão modo-temporal, e têm a estrutura interna de um sintagma nominal (LEHMANN, 1988).

(4-2)a. Pedro viu que João entregou os documentos para Renata.

b. Pedro pediu que João entregasse os documentos para Renata.

c. Pedro viu os meninos entregarem os documentos para Renata

d. Pedro quer entregar os documentos para Renata

e. Pedro viu a entrega dos documentos para Renata [por Pedro].

Grupo de Fatores 2 - Possibilidade de ocorrência dos diferentes tipos de complementação (além do tipo encontrado)

a) indicativo

b) subjuntivo

c) infinitivo pessoal

d) infinitivo impessoal

e) nominalização 
f) indicativo e subjuntivo

g) subjuntivo e infinitivo pessoal

h) subjuntivo e infinitivo impessoal

i) infinitivo pessoal e nominalização

j) infinitivo pessoal e infinitivo impessoal

k) subjuntivo, infinitivo pessoal e impessoal

O grupo de fatores (2) permite verificar a possibilidade de ocorrência dos diferentes tipos de complementação, mesmo eles não aparecendo no corpus. Como salientado neste capítulo, para completar o continuum dos tipos de construções encaixadas completivas, que constituem as possibilidades codificadas pela gramática, quando for o caso, construo exemplos baseados na intuição, muitas vezes representados por construções selecionadas na internet. Os exemplos construídos intuitivamente têm por base as ocorrências reais encontradas no material de análise. Assim, além da construção como (4-3a), selecionada no corpus, foram testadas outras possibilidade de ocorrência, (4-3b) e (4-3c), de modo a verificar se o português licencia, para o verbo começar, outras formas de expressão do complemento além da forma não-finita. A marcação com (*) em (4-3c) indica que, de acordo com minha própria intuição, o fasal começar não licencia estruturas com verbo finito.

(4-3)a. ... "cadê a mãe desse moleque num sei quê?" - aí veio uma senhora FORte -- ele contando assim -- e pegou e falou assim - "é sou eu a mãe" - aí ele começou a discutir nisso veio o pai aí começaram a discutir:: (IBORUNA - AC 051: 165)

b. ... “cadê a mãe desse moleque num sei quê?" - aí veio uma senhora FORte -- ele contando assim -- e pegou e falou assim - "é sou eu a mãe" - aí ele começou a discutir nisso veio o pai aí começaram a discussão::

*c. ... "cadê a mãe desse moleque num sei quê?" - aí veio uma senhora FORte -- ele contando assim -- e pegou e falou assim - "é sou eu a mãe" - aí ele começou a discutir nisso veio o pai aí começaram que o pai discutiu com a senhora :: 
Grupo de Fatores 3 - Tipos semânticos de predicado da oração matriz

(i) predicados encaixadores de enunciação

(ii) predicados encaixadores de atitude proposicional

(iii) predicados encaixadores de conhecimento

(vi) predicados encaixadores volitivos

(v) predicados encaixadores de manipulação

(vi) predicados encaixadores de percepção física

(vii) predicados encaixadores fasais

(viii) predicados encaixadores de experiência psicológica

(ix) predicados encaixadores de tentativa

Esse grupo de fatores classifica os predicados encaixadores segundo sua classe semântica. Segundo Hengeveld (1990), na complementação, a natureza da estrutura subjacente da oração de complemento depende semanticamente do predicado encaixador. Isso significa que o conjunto de expressões possíveis em posição de argumento é diferente para cada predicado selecionador de complemento, devendo-se considerar, portanto, o tipo de predicado e a categoria semântica que o complemento designa.

Para essa classificação, tomou-se como base o conjunto de predicados encaixadores de complemento sugerido por Dixon (2006), complementado por Dik (1997b), Cristofaro (2003) e Noonan (1985) (cf. Capítulo 2, seção 2.3.2, p. 84): de enunciação (4-4), de atitude proposicional (4-5), de conhecimento (4-6), de percepção física (4-7), de manipulação (4-8), de volição (4-9), fasal (4-10), de experiência psicológica (4-11) e de tentativa (4-12):

(4-4) Pedro disse que Carlos virá para o casamento.

(4-5) Eu acredito na vitória da esquerda nas próximas eleições presidenciais

(4-6) João soube que Maria viajou na semana passada. 
(4-7) Leo viu Ana passar em frente à sua casa.

(4-8) João fez Valdomiro entregar a relação de cargos de confiança do terceiro escalão.

(4-9) Eu quero preparar uma prova difícil.

(4-10) Renata parou de chorar porque viu que não adiantava

(4-11) Ana adora pintar telas ao ar livre

(4-12) João tentou encontrar os documentos perdidos.

A partir desse grupo de fatores, será possível examinar as possíveis correlações existentes entre o sistema de tipos de complementação do português brasileiro, tendo como base os tipos de predicado sugeridos por Dixon (2006) e outros autores, e a Hierarquia de Ligação, tal como proposta por Givón (1980). Na tipologia de complementos, Givón (1980) estabelece uma relação entre a estrutura semântica do predicado encaixador, que pode ser vista como um fato indicativo do grau de integração da oração subordinada à oração matriz, e a estrutura sintática dos complementos, como a dependência temporal entre os eventos, a identidade entre os referentes nas duas orações e o traço [+/- controle] dos sujeitos envolvidos.

\section{- Hipótese 2}

No caso de haver alternância entre diferentes formas de expressão das predicações dependentes, não diretamente motivada pela natureza semântica do predicado encaixador, suspeita-se de que a seleção dos diferentes tipos depende de motivações funcionais governadas pelo princípio funcional de economia, que representa uma pressão para a simplificação máxima da expressão. Trata-se aqui, de acordo com Haiman (1983), do princípio de economia sintagmática ou discursiva, que explica a tendência pela omissão de informação redundante ou recuperável no contexto.

Segundo Cristofaro (2003), a economia sintagmática explica a correlação entre a 
predeterminação de traços semânticos de estados de coisas conectados e os fenômenos morfossintáticos que levam à não especificação de informação correspondente. Por exemplo, não precisa ser especificada a referência temporal, aspectual ou modal de um estado de coisas que for predeterminada por traços semânticos do predicado da oração matriz, ou de qualquer outro tipo de oração não-encaixada. Similarmente, também prescindem de especificação na segunda oração participantes que forem compartilhados por dois estados de coisas conectados.

O levantamento de evidências empíricas que possam fornecer evidências para a comprovação ou não dessa hipótese resume aos seguintes parâmetros:

(i) análise das restrições de seleção possíveis dada pela natureza semântica do predicado da oração matriz sobre a natureza do complemento.

(ii) análise das situações de compartilhamento de categorias, como evidência de entrelaçamento, ou coparticipação, como compartilhamento de participantes, de tempo modo e aspecto verbais.

Grupo de Fatores 4 - Codificação dos participantes

a) correferencialidade entre participantes

b) participantes diferentes (não-correferenciais)

O grupo de fatores (4), um parâmetro de análise que está, em geral, presente em nos trabalhos de natureza funcional que tratam das construções encaixadas (KOPTJEVSKAJATAMM, 1993; CRISTOFARO, 2003; MALCHUKOV, 2004), diz respeito à codificação dos participantes, significando particularmente o exame do grau de compartilhamento de participantes do evento encaixado e do evento matriz, que pode implicar em especificação ou não de argumentos na predicação dependente. 
O grau de maior ou menor sentencialidade ou nominalidade do complemento está relacionado ao compartilhamento de participantes, que constitui, portanto, um fator semântico relevante na seleção/restrição do tipo de completiva. Um verbo volitivo como querer, por exemplo, permite a expressão do complemento como oração finita (4-14a) e como nominalização (4-14c), mas não licencia um complemento sob a forma de uma construção não-finita quando não há compartilhamento de sujeitos. Quando há correferência entre os sujeitos da oração matriz e da oração encaixada, pode-se esperar a ocorrência dos dois tipos de complementação, com infinitivo e nominalização, como mostram (4-15b-c); a ocorrência com oração finita (4-15a) somente é possível com participantes não correferenciais.

(4-14)a. João quer que Pedro relate os últimos acontecimentos.

*b. João quer Pedro relatar os últimos acontecimentos.

c. João quer o relato [de Pedro] dos últimos acontecimentos.

(4-15)*a.. João quer que ele relate os últimos acontecimentos.

b. João quer relatar os últimos acontecimentos.

c. João quer seu próprio relato dos últimos acontecimentos.

Grupo de Fatores 5 - Correlações temporais

a) relação de simultaneidade

b) relação de anterioridade

c) relação de posterioridade

O grupo de fatores (5) examina as correlações temporais existentes entre o predicado encaixador e a oração completiva. Givón (1990) considera a relação entre a referência temporal do evento na oração matriz e a do evento na oração completiva como um dos fatores mais relevantes para a integração gramatical entre duas orações. Para o autor, quanto mais temporalmente sequenciais forem os eventos da matriz e da completiva maior será a 
dependência temporal entre esses eventos e maior também será o grau de integração semântico-cognitiva entre as duas orações, possivelmente refletido na expressão formal da construção completiva. Givón (1990, p. 520) resume essa sua consideração na seguinte “inferência probabilística": "Quanto mais cotemporais são os dois eventos, maior é a probabilidade de que eles não sejam independentes um do outro", ${ }^{67}$

Os exemplos abaixo ilustram a marcação de anterioridade (4-16a), simultaneidade (416b) e posterioridade (4-16c) da completiva em relação à oração matriz:

(4-16)a. João contará que Ana participou da reunião.

b. João vê Maria sair do prédio

c. João mandou que Ana saísse da reunião.

\section{- Hipótese 3}

Suspeita-se de que a relação de gradação entre maior ou menor grau de sentencialidade, que se correlaciona ao grau de verbalidade/nominalidade da construção dependente, está vinculada aos níveis e às camada de organização estrutural definidos pela GDF (HENGEVELD; MACKENZIE, 2008).

O levantamento de evidências empíricas que possam fornecer suporte para a comprovação ou não dessa hipótese se resume na verificação da atuação das camadas hierárquicas de organização da GDF (HENGEVELD; MACKENZIE, 2008), nos Níveis Interpessoal e Representacional. Os parâmetros destinados ao exame da frequência dessa correlação possível são definidos como grupo de fatores 6 na análise quantitativa.

\footnotetext{
${ }^{67}$ Cf. o original: The more co-temporal two events are, the higher is the probability that they are not independent of each other.
} 
Grupo 6 - Representação da oração completiva

a) camada do conteúdo comunicado (Nível Interpessoal)

b) camada da proposição (Nível Representacional)

c) camada do estado de coisas (Nível Representacional)

d) camada da propriedade (Nível Representacional)

As relações completivas são identificadas com base no predicado que codifica o estado de coisas principal, ou predicados encaixadores de complemento. As diferentes relações de complementação dizem respeito aos diferentes níveis de estrutura da oração, por isso torna-se relevante observar o nível de representação da oração completiva, tendo em vista o predicado encaixador. O tipo de unidade semântico-funcional que uma oração completiva representa parece refletir o grau de integração gramatical (maior ou menor) que essa oração mantém com sua oração matriz.

Os exemplos a seguir ilustram construções que correspondem a um conteúdo comunicado (4-17), a uma proposição (4-18), a um estado de coisas (4-19) e a uma propriedade (4-20):

(4-17) João disse que Maria construiu uma casa.

(4-18) Pedro acredita que Renata virá para o jantar.

(4-19) João quer a construção dos edifícios.

(4-20) Pedro parou de fumar.

Esse grupo de fatores trata da natureza do complemento como tipo de entidade, isso porque o conjunto de expressões possíveis em posição de argumento é diferente para cada verbo encaixador de complemento e depende da categoria semântica que o complemento designa. 
Hengeveld (1989) sugere que construções subordinadas sejam classificadas de acordo com a camada mais alta que as contém. Diferentes predicados encaixadores requerem diferentes tipos de complemento: o verbo dizer, por exemplo, requer um argumento que designe um evento vinculado a um ato ilocutório declarativo, pressuposto no predicado dizer; o verbo, acreditar, por sua vez, toma um conteúdo proposicional como argumento. Os complementos podem, então, ser caracterizados segundo o tipo de entidade que designam.

\section{- Hipótese 4}

Suspeita-se, por fim, de que o grau de sentencialidade no português falado segue as mesmas condições tipológicas que definem posições diferentes numa escala implicacional, em função de diferentes formas de expressão. O grau de sentencialidade das subordinadas completivas está diretamente vinculado ao grau de preservação ou perda da referência semântica a tempo/aspecto/modo e aos participantes do estado de coisas da completiva, marcas que definem, respectivamente, a sentencialidade de grau máximo e a sentencialidade de grau mínimo.

Como se trata da principal generalização que este trabalho pretende atingir, os resultados parciais relativos à análise de todos os grupos de fatores previstos para a avaliação quantitativa das evidências empíricas constituem evidência para a resolução dessa hipótese. 


\section{CAPÍtULO 5}

\section{DESCRIÇÃO FUNCIONAL DOS TIPOS DE \\ CONSTRUÇÕES ENCAIXADAS NOMINAIS E VERBAIS}

\subsection{Considerações iniciais}

Os resultados do tratamento empírico são apresentados neste capítulo, mediante a descrição e interpretação dos dados. Constitui, portanto, o ponto de partida para a comprovação da hipótese da correlação entre predicados encaixadores e tipos de completivas e da relação entre tipos de completivas e a camada de representação, nos termos da GDF.

Inicialmente, a seção 5.2 apresenta uma descrição geral do tipo de completiva em função do tipo de predicado encaixador e do tipo de unidade semântico-funcional que os complementos representam, com o objetivo de mostrar que diferentes predicados matrizes levam a diferentes tipos de construção encaixada. O foco da descrição apresentada nessa seção é a construção formal da oração completiva com base na semântica do predicado encaixador, que permite distinguir a categoria semântica da construção completiva.

A especificação dos resultados torna-se ainda mais detalhada na seção 5.3, que trata separadamente de cada tipo de predicado encaixador e do tipo de complemento selecionado. Essa seção é dividida em subseções, cada qual abordando um tipo específico de predicado encaixador, de modo a facilitar a exploração dos dados e facilitar a compreensão do leitor.

A seção 5.4 apresenta os resultados referentes a outros fatores que, assim como o tipo semântico do predicado encaixador, também podem determinar a forma que a completiva assume: trata-se do compartilhamento de participantes e de referência TAM. Essa seção também mostra que, no corpus analisado, determinadas formas completivas podem ser restringidas ou facultadas por aspectos relacionados à integração semântica. 
O critério para o levantamento da amostra consiste na seleção de orações completivas segundo uma hierarquia com cinco distinções, que mostra o grau de sentencialidade/nominalidade do complemento (cf. Capítulo 4, seção 4.4, p.142):

(5-1) Grau de sentencialidade/nominalidade do complemento indicativo $<$ subjuntivo $<$ inf. pessoal $<$ inf. impessoal $<$ nominalização em que '<' significa menos nominal do que

De um modo geral, essa hierarquia encontra-se representada em vários trabalhos da literatura linguística no que diz respeito à subordinação/complementação, como, por exemplo, na Hierarquia de Ligação de Givón (1980), na distinção entre os tipos de complementos de Noonan (1985) e nos parâmetros de dessentencialização de Lehmann (1988).

Para a referência aos tipos de completivas em relação à camada de representação, usei a taxonomia que aparece em Hengeveld e Mackenzie (2008, p. 364), apresentada aqui no Capítulo 3, seção 3.5 (p.131-134): C- complemento para conteúdos comunicados, pcomplemento para conteúdos proposicionais, e-complemento para estados de coisas e fcomplemento para propriedade.

Tendo em vista essa classificação para os tipos de completivas, cabe salientar que, no corpus analisado, restrito a determinados tipos de predicados encaixadores, não foram encontradas ocorrências representativas de M-complementos para moves, como em (5-2), e de A-complementos para atos discursivos, como em (5-3), fato que justifica, portanto, a ausência desses tipos na análise apresentada.

(5-2) Embora seja difícil fazer generalizações sobre um público tão diverso, é fácil concluir [que, em suma, essas ações levaram a uma perda líquida da cobertura vegetal em relação às condições pré-colonização, bem como a uma mudança substancial no tipo da atual vegetação. Ao mesmo tempo, a consciência pública concernente à importância da vegetação urbana certamente tem aumentado nos últimos dez anos, embora seja uma questão aberta quanto daquela conscientização traduziu-se em mudança de comportamento 
em comparação com as áreas urbanas plantadas em Quito. $]^{68}$

(5-3) Acrescentou, ainda, que a cópia do depósito recursal não está devidamente autenticada (Adaptado de Braga, 2008, p. 12)

Isso significa que, hierarquicamente, na análise aqui proposta, a camada mais alta de representação no Nível Interpessoal é a do conteúdo comunicado. O Nível Representacional contempla desde conteúdos proposicionais até propriedades, hierarquicamente, a camada mais baixa em relação a estado de coisas, episódio e conteúdo proposicional. ${ }^{69}$

Como apresentado nos Capítulos 2 e 4, na análise aqui proposta, tomam-se por base os tipos de predicados propostos por Dixon (2006), complementados por Dik (1997b), Cristofaro (2003) e Noonan (1985). O Quadro 5-1 apresenta a classificação geral utilizada neste trabalho, com os predicados encontrados no corpus:

\begin{tabular}{|l|l|}
\hline Tipo de predicado encaixador & \multicolumn{1}{|c|}{ Predicados encontrados no corpus } \\
\hline de Enunciação & dizer, falar, contar, perguntar \\
\hline de Atitude proposicional & achar, acreditar, pensar \\
\hline de Conhecimento & saber, esquecer, lembrar, ver, perceber \\
\hline de Volição & querer, pretender \\
\hline de Manipulação & mandar, pedir, obrigar, permitir, deixar \\
\hline de Percepção física & ver, ouvir \\
\hline Fasais & começar, iniciar, parar, continuar \\
\hline de Experiência psicológica & gostar, preferir \\
\hline de Tentativa & tentar, procurar \\
\hline
\end{tabular}

Quadro 5-1: Tipos de predicados encaixadores considerados para análise

\footnotetext{
${ }^{68}$ Exemplo retirado de Hengeveld e Mackenzie (2008, p.364). Cf o original: While it is difficult to make generalizations about such a diverse public, it is easy to conclude [that, in sum these actions have led to a net loss of vegetative cover relative to pre-settlement conditions, as well as a substantial change in the type of vegetation present. At the same time, public consciousness regarding the importance of urban vegetation has certainly risen in the last ten years, although how much of that awareness has translated into changed behavior vis a vis urban plants in Quito is an open question.]

${ }^{69}$ Com exceção das unidades representativas do Nível Interpessoal, todas as outras estruturas são consideradas unidades semânticas, como já apresentado no Capítulo 3, e é em termos dessas unidades que as orações completivas são tratadas na GDF (HENGEVELD; MACKENZIE, 2008).
} 
Feitos esses esclarecimentos, passemos, agora, à descrição e à interpretação dos dados, com base nos critérios apresentados no capítulo anterior e aqui ligeiramente sumarizados.

\subsection{Descrição funcional dos tipos de completivas no corpus: aspectos gerais}

Antes de explorar separada e detalhadamente a relação entre o tipo de predicado encaixador de complemento e o tipo de oração completiva requerida, apresento, inicialmente, os resultados gerais que dizem respeito (i) à distribuição dos tipos de orações completivas de acordo com o tipo semântico de predicado encaixador, apresentada na Tabela 5-1, e (ii) aos tipos de entidades semânticas representadas, apresentados na Tabela 5-2. Esses resultados serão discutidos quantitativa e qualitativamente nas seções seguintes.

Tabela 5-1: Tipos de completivas segundo o tipo de predicado encaixador ${ }^{70}$

\begin{tabular}{|c|c|c|c|c|c|c|c|c|c|c|c|c|}
\hline \multirow[t]{2}{*}{ Predicado encaixador } & \multicolumn{2}{|c|}{ IND } & \multicolumn{2}{|c|}{ SUBJ } & \multicolumn{2}{|c|}{ INF PES } & \multicolumn{2}{|c|}{ INF IMPES } & \multicolumn{2}{|c|}{ NOM } & \multicolumn{2}{|c|}{ Total } \\
\hline & $\mathrm{N}$ & $\%$ & $\mathrm{~N}$ & $\%$ & $\mathrm{~N}$ & $\%$ & $\mathrm{~N}$ & $\%$ & $\mathrm{~N}$ & $\%$ & $\mathrm{~N}$ & $\%$ \\
\hline de Enunciação & 36 & 100 & & & & & & & & & 36 & 11 \\
\hline de Atitude proposicional & 16 & 100 & & & & & & & & & 16 & 5 \\
\hline de Conhecimento & 24 & 76 & & & & & 4 & 12 & 4 & 12 & 32 & 9 \\
\hline de Volição & 4 & 5 & 32 & 38 & & & 44 & 52 & 4 & 5 & 84 & 24 \\
\hline de Manipulação & 1 & 3 & 2 & 6 & 22 & 69 & & & 7 & 22 & 32 & 9 \\
\hline de Percepção física & 2 & 20 & & & 8 & 80 & & & & & 10 & 3 \\
\hline Fasal & & & & & & & 92 & 95 & 5 & 5 & 97 & 28 \\
\hline de Experiência psicológica & & & & & & & 25 & 100 & & & 25 & 7 \\
\hline de Tentativa & & & & & & & 14 & 100 & & & 14 & 4 \\
\hline Total & 83 & 24 & 34 & 10 & 30 & 8 & 179 & 52 & 20 & 6 & 346 & \\
\hline
\end{tabular}

\footnotetext{
${ }^{70}$ A tabela 5-1 introduz a análise em função de sua relevância metodológica: é o ponto de referência básico para o estabelecimento das correlações que serão feitas a seguir.
} 
Os dados apresentados na Tabela 5-1 fornecem uma tendência geral na distribuição de tipos de predicados encaixadores e tipos de complemento, que, como será apresentado, envolve integração semântica. Retomemos a escala de gradação que mostra o grau de sentencialidade/nominalidade da oração completiva:

(5-4) Tipo de complemento e grau de sentencialidade/nominalidade

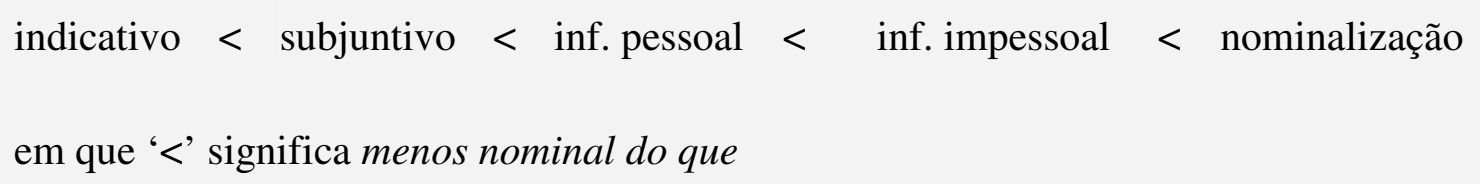

Com base nessa escala, pode-se colocar no extremo mais verbal predicados cujo complemento é representado por orações finitas no indicativo e no subjuntivo e, no extremo mais nominal, complementos oracionais não-finitos com infinitivo e nominalização.

Os predicados encaixadores de complementos foram organizados na Tabela 5-1 de modo a representar a escala gradativa apresentada em (5-4). Hierarquicamente, aparecem dispostos, na parte extrema superior, os predicados que requerem em sua maioria complementos mais verbais e, na parte extrema inferior, os predicados que requerem complementos mais nominais. Desse modo, os predicados de enunciação, de atitude proposicional e de conhecimento encabeçam o topo de predicados cujos complementos são, majoritariamente, verbais.

No outro extremo da escala estão os predicados de tentativa, de experiência psicológica, fasais, de percepção física, de manipulação e volitivos, que, preferencialmente, vêm acompanhados de complementos mais nominais. Predicados volitivos e de manipulação, embora também requeiram complementos nominais, em relação aos anteriores, permitem também completivas mais verbais. Essa flexibilidade de comportamento os posiciona na parte média da escala. 
A ocorrência de maior ou menor sentencialidade ou nominalidade do complemento está relacionada não só ao predicado encaixador, mas também ao compartilhamento de participantes, que constitui, portanto, um segundo fator semântico relevante na seleção/restrição do tipo de completiva. Essa discussão, no entanto, ficará para as seções seguintes.

A tendência apresentada na Tabela 5-1 pode ser visualmente representada no Gráfico 5-1:

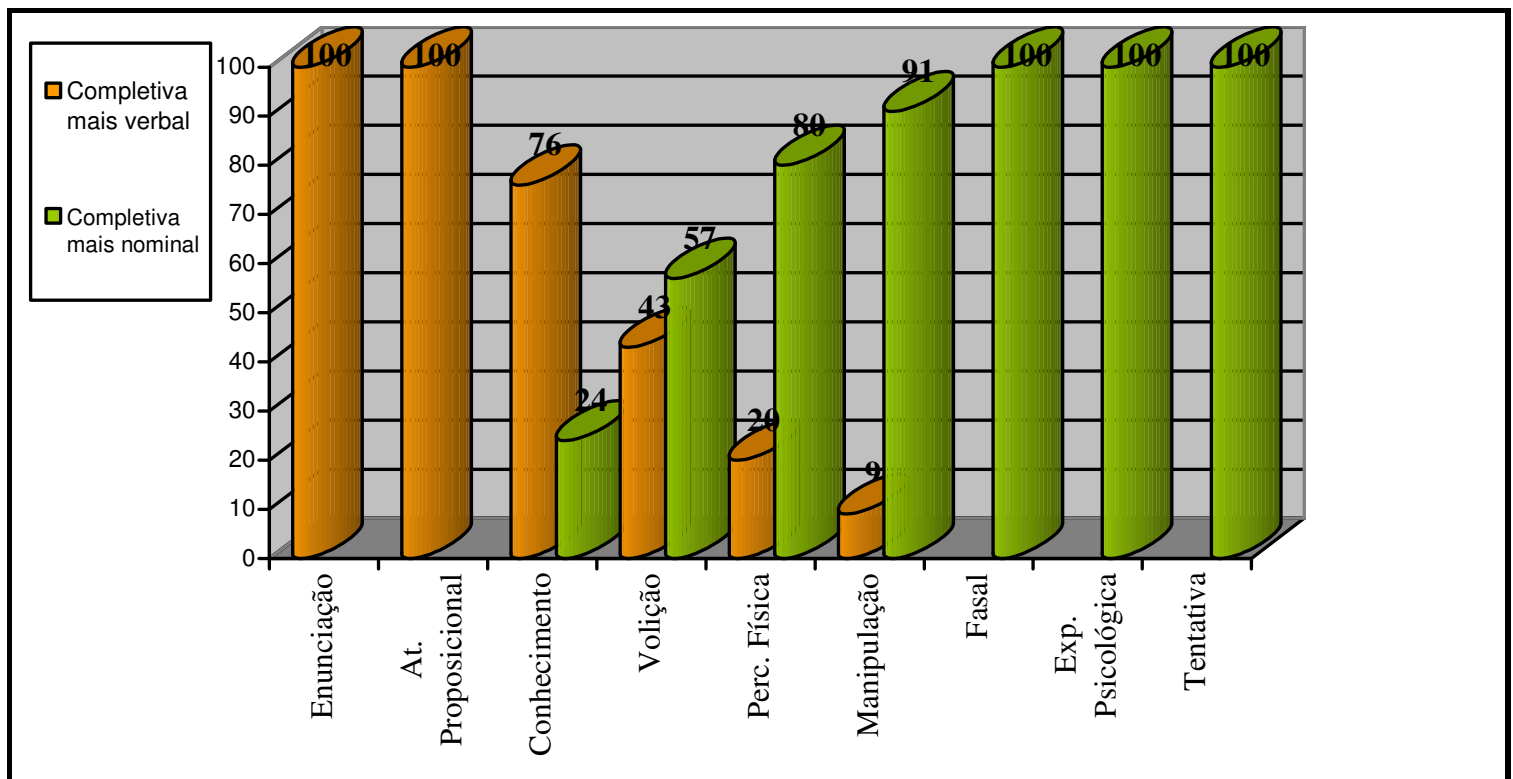

Gráfico 5-1: Tipos de predicado encaixador e tipos de complemento

Da esquerda para a direita, a tendência representada no Gráfico 5-1 - que respeita o tipo de predicado encaixador - é a diminuição gradativa da verbalidade do complemento requerido em direção a um grau crescente de nominalidade. Noutra perspectiva, da direita para a esquerda, pode-se pensar na diminuição da nominalidade do complemento em direção à verbalidade.

Aprofundando um pouco mais essa observação, predicados que requerem (ou que, além de complementos nominais, aceitam) complementos mais verbais também podem ser observados a partir do critério de maior/menor verbalidade, como ilustra o Gráfico 5-2: 


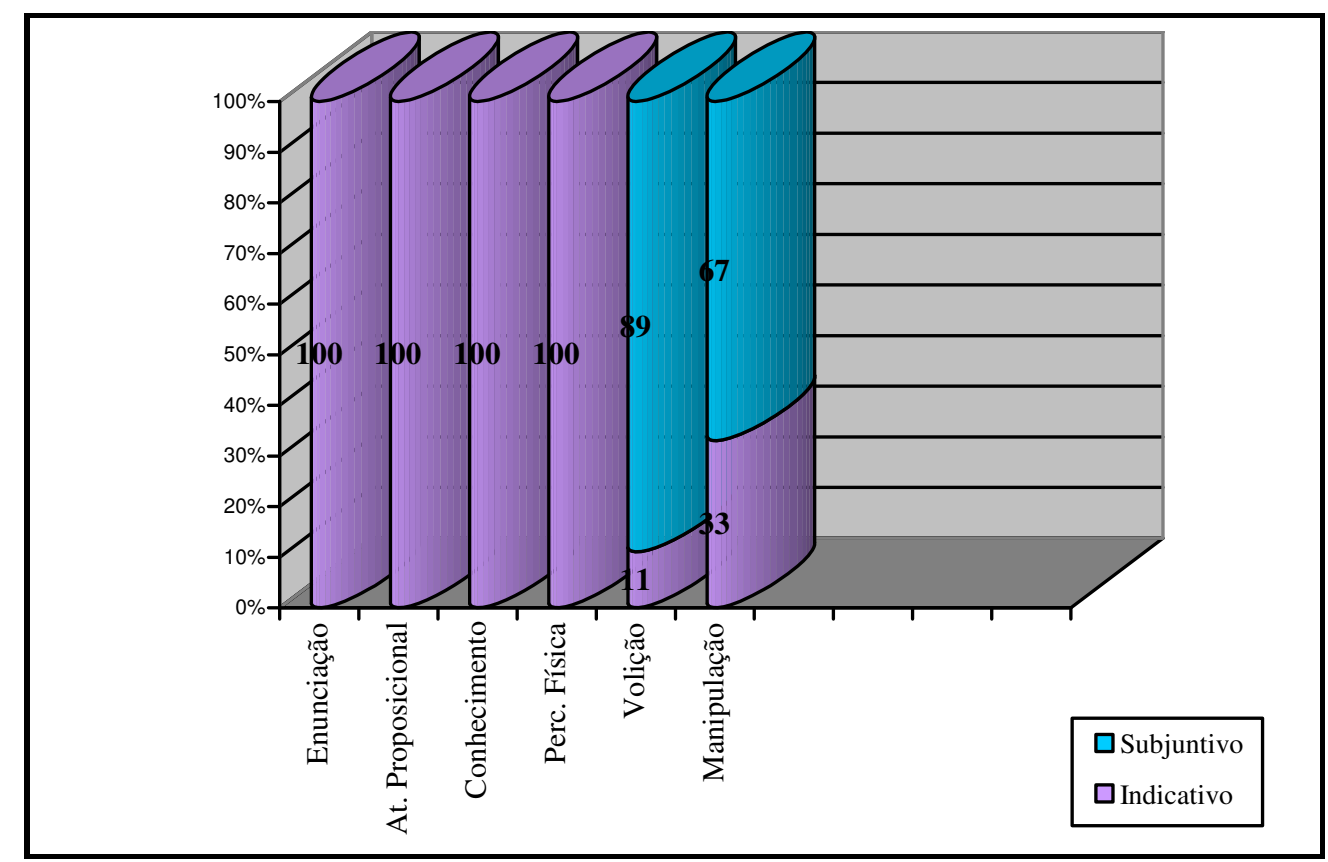

Gráfico 5-2: Predicados encaixadores e complementos verbais (com base no corpus)

Considerando que o grau máximo de verbalidade é a forma do indicativo e que o grau comparativamente menos verbal em relação ao indicativo é o subjuntivo, é possível afirmar que predicados encaixadores de enunciação, de atitude proposicional, de conhecimento e de percepção física requerem exclusivamente complementos mais verbais do que os predicados de volição e de manipulação. Ao selecionarem complementos menos verbais, esses últimos licenciam majoritariamente a forma do subjuntivo. As ocorrências em (5-5a-f) ilustram casos de predicados encaixadores de enunciação, de atitude proposicional, de conhecimento e de percepção física, com complementos finitos no indicativo, e de predicados de volição e de manipulação, com complementos finitos no subjuntivo, respectivamente:

(5-5)a. Doc.: assim... cê me disse que cê estuda na COOPEN né? ce poderia me descrever como é a tua esco::la?... (IBORUNA - AC 012: 120)

b. o senhor acha que essa preocupação do pai com o aluno essa observação no aluno é:: ajuda no desenvolvimento do aluno na esco::la é importa::nte?...(IBORUNA - AC $145: 291)$

c. e:: eu vou contar agora do:: ah minha amiga que ficou com o meu colega e ela me ela num queria me conta::r que ela sabe que eu ia brigar com ela porque eu num gosto muito dele que é muito galinha... (IBORUNA - AC 016: 139) 
d. ... assim na hora que ele puxou- e ele correu ... um BAITA de um negão cumprido assim ... é novo mas aqueles mulecão alto ... ai mas eu corri grita:ndo e xinga:ndo ... e xinguei tudo quanto é nome MESMO ... e fui atrás mas corri ... corri atrás dele "filha da puta ... vem cá:: ((risos)) eu/ me dá minha chave::... não tem dinheiro aí .. não tem nada::: me dá minha chave" ... e fui correndo ... corri ... corri ... ele pegou e:: ... sabe ... FOI CORRENDO abrindo a bolsinha .... ele viu que não tinha nada ...- tinha um real dos reais -...ele pegou e viu que eu tava corre::ndo ... eu não ia desistir eu ia correr atrás dele até o/ até quando eu conseguir ... aí ele pegou e:: jogou a bolsinha n/no chão ... com a chave tudo ... (IBORUNA - AC 062:99)

e. Inf.: ah! que meu pai contou é meu pai contava que:: quando ele namorava minha mãe minha mãe era era muito bonita né e tinha bastante moço que gostava dela não queria que ele namorasse (IBORUNA - AC 136: 084)

f. eu pedi que ele fosse me visitar pra que a gente falasse da bíblia... (IBORUNA - AC 124: 011)

Em relação aos predicados que requerem (ou que, além de complementos verbais, aceitam) complementos mais nominais, a distribuição é mais intrincada:

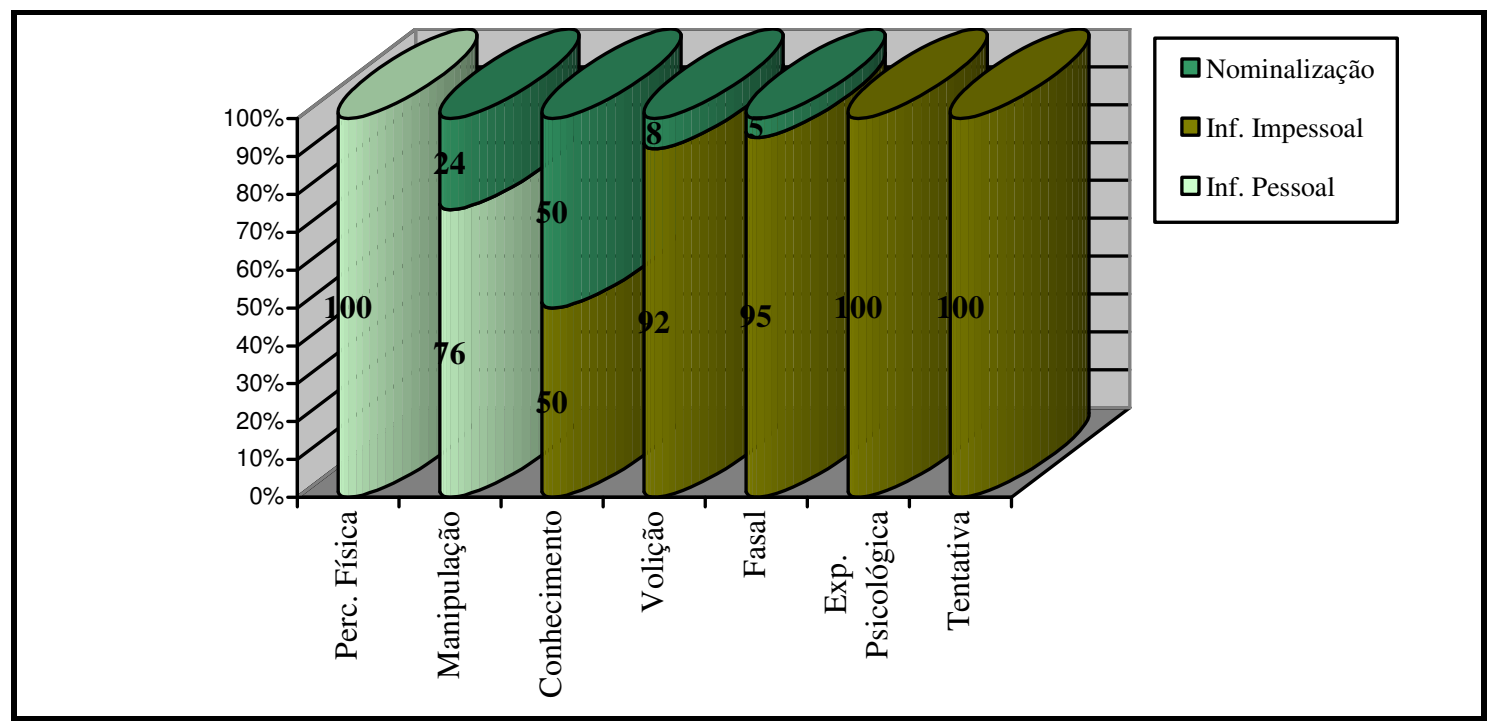

Gráfico 5-3: Predicados encaixadores e complementos nominais (com base no corpus)

Considerando como menos nominais os complementos não-finitos com infinitivo pessoal e como mais nominais os complementos não-finitos com infinitivo impessoal e com nominalização, é possível sustentar que os predicados encaixadores de percepção física e de manipulação são mais verbais em relação aos outros por selecionarem exclusiva ou majoritariamente complementos no infinitivo pessoal. Essa é uma especificidade desses 
predicados. Os verbos manipulativos são predicados cujos participantes não são correferenciais - portanto, são predicados com menor grau de integração semântica em relação aos demais - e, quando requerem complementos no infinitivo, a forma escolhida é, necessariamente, o infinitivo pessoal, como aparece em (5-6-a-b):

(5-6)a. eu tava em ca::sa meu pai ligou éh:: meio nervoso assim que tinha acontecido alguma coisa e eu atendi o telefone... aí ele mandou eu chamar a minha tia mas eu perguntei o que aconteceu e ele não queria me falar... (IBORUNA - AC 008:051)

b. Polícia mandou vizinhos de Eloá saírem de apartamento antes da invasão (Fonte:http://oglobo.globo.com/sp/mat/2008/10/22/policiamandouvizinhosdeeloasairem586062123.asp)

Os predicados de percepção física podem apresentar tanto participantes correferenciais quanto participantes não-correferenciais com infinitivo pessoal, como em (5-7a-b):

(5-7)a. Sentadinha neste lugar fora de mim, eu me vi engordar $12 \mathrm{~kg} \mathrm{em} \mathrm{um} \mathrm{ano.}$

(Fonte: http://comosefosseaprimeiravez.blogs.sapo.pt/6505.html?replyto=43369)

b. ... e diz que ele tava assim perto da porta... ele viu passar um:: um::/ ele não sabe identificar mas diz que é uma sombra... (IBORUNA - AC 035: 230)

Os predicados de volição (5-8a), fasais (5-8b), de experiência psicológica (5-8c) e de tentativa (5-8d) compartilham participantes com o complemento e, por isso, a expressiva manifestação do predicado sob a forma de infinitivo impessoal. Os predicados de volição, especificamente, quando não compartilham participantes com o complemento, requerem subjuntivo na oração dependente.

(5-8) a. Inf.: ... acontece que eu num tô ven(d)o um fim pra minha... (dissertação de mestrado) eu não sei onde eu quero chegá(r)... sabe? eu num tenho... ai eu quero estudá(r) tal coisa eu quero prová(r) tal resultado [(inint.)] (IBORUNA - AI 011: 107)

b. depois apareceu a Chagas no intesti::no... né... aí então cê vê... foi aquele tratamen::to... mé::dico... mé::dico... parou de trabalhar:: porque o médico proibiu... (IBORUNA - AC 132: 020)

c. então eu acho que a:: sobre a puniÇÃo éh:: a gente não gosta de punir ninGUÉM entendeu? (IBORUNA - AC 141: 164)

d. Inf.: das outras vezes ele:: ele tentou matar acho que um:: um moço... ele foi preso 
também... (IBORUNA - AC 039: 127)

As nominalizações aparecem com predicados encaixadores de conhecimento (5-9a), de volição (5-9b), de manipulação (5-9c) e fasais (5-9d). A tendência representada no Gráfico 5-3 é o reflexo da frequência das ocorrências detectadas no corpus. Cabe salientar, entretanto, que tanto predicados encaixadores de experiência psicológica quanto predicados de tentativa também licenciam a ocorrência de complementos nominalizados, como mostram (5-9e) e (59f), respectivamente.

(5-9)a. aí eu e/ eu esqueço das outras coisas eu esqueço de bagagem eu esqueço de/ de check in de conferência de bilhete esqueço de desembarque esqueço de embarque esqueço de tudo (IBORUNA - AC 051: 366)

b. e eu já tava meio envolvido com E:la e ele pressioNOU pressioNOU basTANte... a mãe NÃO queRIA namoro só que o pai dela falou que era pá ficar aqui na porta de CAsa... (IBORUNA - AC 047: 114)

c. ... aí hum tava/ trabalhava eu e mais três pessoas uma dessas pessoas dessas/ o Laércio foi:: pediu demissão porque ele ia embora pro Japão fazer um curso de línguas (IBORUNA AC 051: 126)

d. ::... e ele tava no ônibus e quando ele sentou... ele sentou numa coisa da/ na cadê::ira... e sentou e até cont/ e continuou a via::gem... vindo de São José do Rio Preto pra Bady Bassit... (IBORUNA - AC 035: 160)

e Enquanto o Congresso e o governo negociam mudanças nos atuais limites do desmatamento no país, uma pesquisa Datafolha mostrou que $94 \%$ dos entrevistados preferem a suspensão do abate de árvores...

(Fonte: http://www1.folha.uol.com.br/folha/brasil/ult96u557875.shtml)

f. A editora Rocco voltou a perder no Tribunal de Justiça do Paraná na ação que tentava a liberação do livro "Canto dos Malditos", do escritor Austregésilo Carrano, 45, proibido preventivamente pelo mesmo tribunal em maio passado.

(Fonte: http://www1.folha.uol.com.br/folha/ilustrada/ult90u27313.shtml)

Uma dedução a que se pode chegar é a de que, para um predicado licenciar uma nominalização como complemento, ele deve, necessariamente, também licenciar uma forma mais verbal. Não há, assim, predicados encaixadores que requeiram somente nominalização. Essa correspondência mostra, portanto, o caráter do estado de coisas identificado nas nominalizações. 
A tendência apresentada na Tabela 5-1 e nos Gráficos 5-1, 5-2 e 5-3, sustentada pelas ocorrências em si, pode ser assim representada:

\section{(5-10) Predicados encaixadores e escala de sentencialidade/nominalidade do complemento}

de Enunciação > de Atitude proposicional > de Conhecimento > de Volição, de Manipulação, de Percepção física $>$ Fasal $>$ de Experiência psicológica $>$ de Tentativa

em que '>' significa mais verbal do que

Como será desenvolvido no Capítulo 6, essa hierarquia diverge em alguns aspectos das que foram propostas por Cristofaro (2003) e por Givón (1980), sobretudo no que diz respeito à nominalidade do complemento de alguns tipos de predicados encaixadores. Cristofaro considera que predicados como os de enunciação, de atitude proposicional e de conhecimento requerem complementos finitos, na medida em que a relação entre o predicado encaixador e a completiva não envolve integração semântica. Na hierarquia de ligação de Givón, essa hipótese também parece prevalecer. A diferença entre o que postulam Cristofaro e Givón e os resultados aqui obtidos está no fato de, nas ocorrências analisadas do português, todos os tipos de predicados, exceto os de enunciação, apresentarem integração semântica em maior ou menor grau em relação aos seus complementos.

Outra dedução que se pode extrair dos resultados apresentados na Tabela 5-1 é a de que $52 \%$ (179/346) dos complementos selecionados são complementos não-finitos com infinitivo impessoal como núcleo. Entretanto, as próximas seções mostrarão que essa predominância tem relação com os tipos de predicados encaixadores que fazem parte da amostra, bem como com o compartilhamento de participantes e referência TAM. Esse aspecto não tem muita relevância quantitativa, mas é extremamente pertinente sua distribuição qualitativa. Além disso, é necessário considerar que o fato de o tipo de completiva assumir determinada forma de expressão não implica necessariamente o não licenciamento de outros 
tipos pelo predicado encaixador.

A Tabela 5-1 mostra ainda que a alternância entre construções finitas e não-finitas está associada a predicados encaixadores que se aproximam do polo mais verbal na escala de sentencialidade/nominalidade, ainda que as finitas prevaleçam sobre as não-finitas. Com predicados encaixadores que se aproximam do polo de maior grau de nominalidade do complemento, não há alternância entre tipos mais verbais e mais nominais e os complementos selecionados simplesmente restringem-se a complementos não-finitos (é o caso dos fasais, dos de experiência psicológica e dos de tentativa).

Essa constatação parece coadunar-se com o fato de que quanto mais baixa a camada que subjaz a uma oração particular tanto maiores as probabilidades de essa oração particular perder os traços específicos de oração principal, isto é, de realizar-se como um complemento mais nominal, não-finito. No modelo da Teoria de Gramática Funcional (DIK, 1997a, 1997b; HENGEVELD, 1989, 1990), a oração pode ser descrita como uma estrutura disposta em camadas e cada camada está contida na imediatamente superior. Segundo Cristofaro (2003), as diferentes relações de complementação pertencem a diferentes níveis de estrutura oracional. $\mathrm{Na}$ amostra analisada, os diferentes tipos de complementação aparecem, de fato, distribuídos em diferentes níveis de representação.

Segundo Hengeveld $(1989,1998)$, as diferenças na forma das orações subordinadas podem ser consideradas em termos de diferenças interpessoal e representacional subjacentes. O que vale destacar, segundo o autor, é que a seleção do tipo de oração complemento depende da natureza das camadas interpessoal e representacional. Uma generalização que se pode fazer é a de que, quanto mais baixo o nível em que se baseia uma oração subordinada, tanto maior é a probabilidade de ela ser do tipo dessentencializado.

A Tabela 5-2 toma por base a camada de representação definida pela GDF: 
Tabela 5-2: Camada de representação do complemento

\begin{tabular}{|c|c|c|c|c|c|c|c|c|c|c|c|c|}
\hline \multirow{2}{*}{ Camada de representação } & \multicolumn{2}{|c|}{ IND } & \multicolumn{2}{|c|}{ SUBJ } & \multicolumn{2}{|c|}{ INF PES } & \multicolumn{2}{|c|}{ INF IMPES } & \multicolumn{2}{|c|}{ NOM } & \multicolumn{2}{|c|}{ Total } \\
\hline & $\mathrm{N}$ & $\%$ & $\mathrm{~N}$ & $\%$ & $\mathrm{~N}$ & $\%$ & $\mathrm{~N}$ & $\%$ & $\mathrm{~N}$ & $\%$ & $\mathrm{~N}$ & $\%$ \\
\hline Conteúdo comunicado & 36 & 100 & & & & & & & & & 36 & 10 \\
\hline Conteúdo proposicional & 40 & 84 & & & & & 4 & 8 & 4 & 8 & 48 & 14 \\
\hline Estados de coisas & 7 & 3 & 34 & 13 & 30 & 11 & 175 & 67 & 16 & 6 & 262 & 76 \\
\hline Total & 83 & 24 & 34 & 10 & 30 & 8 & 179 & 52 & 20 & 6 & 346 & \\
\hline
\end{tabular}

Os dados apresentados na Tabela 5-2 mostram que, no Nível Interpessoal, os complementos de predicados que introduzem um conteúdo comunicado são exclusivamente verbais. Do mesmo modo, na camada de representação de conteúdo proposicional do Nível Representacional, os complementos também aparecem como formas mais verbais (83\% [40/48]).

Os percentuais relativos à camada de representação de conteúdo comunicado dizem respeito a predicados de enunciação, que requerem C-complementos, enquanto os percentuais relativos à camada de representação de conteúdos proposicionais, que requerem p-complementos, englobam os predicados de atitude proposicional e de conhecimento, que dizem respeito a construtos mentais, avaliados em termos de sua verdade/falsidade.

Como os dados mostrarão, a seleção de um C-complemento ou de um p-complemento aponta para uma tendência geral de ser esse complemento uma oração finita no indicativo. Dito em outros termos: predicados encaixadores de conteúdo comunicado e de conteúdo proposicional selecionam, preferencialmente, complementos mais verbais.

Na camada de representação de estados de coisas, independentemente de se realizarem como formas finitas, os e-complementos são majoritariamente nominais (85\% [221/262]).

Não há uma relação hierárquica entre os níveis de representação; portanto, não se pode afirmar que, em relação a p-complementos e e-complementos, C-complementos sejam, 
hierarquicamente, superiores. Entre camadas do mesmo nível, entretanto, há uma relação hierárquica no que diz respeito ao grau de sentencialidade/nominalidade e tipo de entidade, que pode ser representada nos seguintes termos: complementos mais verbais estão associados à camada mais alta do Nível Representacional, isto é, conteúdos proposicionais, enquanto complementos mais nominais restringem-se às camadas mais baixas de representação, no caso, estados de coisas. Essa relação mostra haver uma correspondência muito relevante entre os tipos de complementos e as camadas de representação postuladas pela GDF.

(5-11) Camada de representação

Conteúdo comunicado

$>\quad$ Estados de coisas

Conteúdo proposicional

em que '>’ significa requer complemento mais verbal

Predicados que introduzem conteúdo comunicado e conteúdo proposicional são os que requerem complementos mais verbais. Na medida em que a camada de representação torna-se mais baixa, maiores as chances de o complemento tornar-se mais dependente e, por conseguinte, realizar-se como um complemento não-finito. Desse modo, em oposição aos anteriores, predicados que introduzem estados de coisas requerem complementos mais nominais.

Relacionando as camadas de representação aos tipos de predicados encaixadores, pode-se chegar à seguinte hierarquia: 
(5-12) Camada de representação e tipo de predicado encaixador

Conteúdo comunicado

predicados de enunciação

\section{Estados de coisas}

predicados de volição, manipulação, de

$>$ percepção física, fasal, de experiência

psicológica e de tentativa

\section{Conteúdo proposicional}

predicados de atitude proposicional

e de conhecimento

em que '>' significa requer complemento mais verbal

A hierarquia em (5-12) apresenta uma correlação: a depender do tipo de complemento requerido - conteúdo comunicado, conteúdo proposicional ou estado de coisas - diferentes formas de codificação são requeridas para as completivas. Predicados matrizes que introduzem um conteúdo comunicado tendem a apresentá-lo numa oração finita; o complemento de predicados que requerem um conteúdo proposicional, como os de atitude proposicional e os de conhecimento, tende a ser codificado na forma finita do indicativo; o complemento de predicados que requerem um estado de coisas, como os volição, de manipulação, de percepção física, fasal, de experiência psicológica e de tentativa, tende preferencialmente a ser codificado em formas mais nominais. $\mathrm{O}$ estatuto mais ou menos verbal/nominal está vinculado à camada de organização estrutural definidas pela GDF (HENGEVELD; MACKENZIE, 2008) nos seguintes termos: quanto mais nominais os complementos mais interna a camada de representação.

Feitas essas considerações, apresento, na seção seguinte, as especificidades de cada tipo de predicado encaixador e o tipo de completiva requerido. 


\subsection{Predicados encaixadores e tipos de completivas}

\subsubsection{Predicados encaixadores de enunciação}

O complemento de predicados de enunciação representa a informação transferida, o conteúdo comunicado (cf. NOONAN, 1985, HENGEVELD; MACKENZIE, 2008). Os exemplos em (5-13a-b) ilustram esse tipo de predicado encaixador:

(5-13)a. ...e aí:: aí a polícia chegou lá falou que NEM sabia dirigir o carro num ti::nha aí ela fícou com:: aquela coisa de mila::gre sabe? (IBORUNA - AC 012: 106)

b. aí ela:: dona Iracel perguntou se eu queria descer... (IBORUNA - AC 051: 109)

Tanto falar, em (5-13a), quanto perguntar, em (5-13b), são predicados que subcategorizam orações completivas que introduzem um conteúdo comunicado. Esses predicados, diferentemente dos demais tipos analisados, não se caracterizam em termos de significado, de tipo de entidade representada por seu complemento, mas em termos da função pragmática de transmitir um conteúdo (cf. HENGEVELD; MACKENZIE, 2008).

Os complementos de dizer e de perguntar são conteúdos comunicados, isto é, Ccomplementos, porque, como a verdade do que está sendo dito ou perguntado depende dos participantes envolvidos na interação verbal, um enunciado dessa natureza diz respeito ao discurso e não à sentença em si. Justamente por isso, a camada relevante de análise para esse tipo de complemento é a do conteúdo comunicado, no Nível Interpessoal. Como um conteúdo comunicado, esses complementos podem ser modificados por material lexical relacionado à ênfase, como realmente, ou por modificadores que expressam a atitude do falante em relação ao conteúdo comunicado, como (in)felizmente, e os reportativos, que indicam que o falante transmite um conteúdo expresso por outros. As ocorrências em (5-13) poderiam ser modificadas da forma como aparecem em (5-14): 
(5-14)a. ...e aí:: aí a polícia chegou lá falou que (segundo testemunhas) (ela) NEM sabia dirigir o carro num ti::nha aí ela ficou com:: aquela coisa de mila::gre sabe? (IBORUNA - AC 012: 106)

b. aí ela:: dona Iracel perguntou se (realmente) eu queria descer...

Se estivessem encaixadas a um predicado como achar ou supor, por exemplo, os complementos que aparecem em (5-13b) seriam designativos de conteúdos proposicionais, portanto, entidades de terceira ordem.

(5-15)a. ...e aí:: aí a polícia chegou lá achou que (provavelmente) (ela) NEM sabia dirigir o carro num ti::nha aí ela ficou com:: aquela coisa de mila::gre sabe?

a'. ...e aí:: aí a polícia chegou lá achou que (*segundo testemunhas) (ela) NEM sabia dirigir o carro num ti::nha aí ela ficou com:: aquela coisa de mila::gre sabe?

b. aí ela:: dona Iracel supôs que (possivelmente) eu queria descer...

b'. aí ela:: dona Iracel supôs que (*de acordo com José) eu queria descer...

Enquanto, no Nível Representacional, os modificadores de conteúdo proposicional se referem ao tipo e ao grau de comprometimento com o conteúdo proposicional, ou à especificação de fonte desse conteúdo, os modificadores do conteúdo comunicado indicam que o falante está relatando o ponto de vista de outro e, por isso, causam estranheza se aplicados em nível e camada diferentes, como ocorre em (5-15a') e (5-15b’). Como a relação entre os predicados falar e perguntar, por um lado, e achar e supor, por outro, e seus complementos ocorre em níveis distintos, a classificação é também correlativamente distinta.

O que a Tabela 5-1, na seção anterior, mostra é que predicados encaixadores de enunciação requerem complementos finitos no indicativo em 100\% das ocorrências (36/36). No entanto, não é vedada a ocorrência de complementos mais nominais com esse tipo de predicado; trata-se, portanto, de uma preferência.

Predicados de enunciação prototípicos, como dizer, parecem não licenciar a codificação do C-complemento em formas mais nominais (considerando a escala gradativa de nominalidade). A forma usualmente preferida é a oração finita no indicativo, conforme 
compravam os resultados. A codificação da completiva no subjuntivo também é possível, como mostra (5-16).

(5-16) Imagine V. Ex ${ }^{\mathrm{a}}$, Senador e Governador Roberto Requião, o que está prestes a acontecer, que bazar persa será instalado no Congresso Nacional! E não digo que essa disposição de barganhar exista no Presidente eleito, Luiz Inácio Lula da Silva, porque, como será a primeira vez que exercerá um cargo executivo, não se pode acusá-lo de já ter feito isso antes.

(Fonte: http://www.senado.gov.br/sf/atividade/pronunciamento/detTexto.asp?t=327621)

O fato de, no corpus analisado, dizer não aparecer com outro tipo de complemento que não a forma finita no indicativo não significa a impossibilidade de ocorrência mais nominal, como em (5-17a-c):

\section{(5-17)a. Marta diz não acreditar em vitória no primeiro turno das eleições}

(Fonte: http://www1.folha.uol.com.br/folha/brasil/ult96u422289.shtml)

b. Lula diz lamentar desaparecimento de avião e torce para que pior não tenha ocorrido (Fonte: http://www1.folha.uol.com.br/folha/cotidiano/ult95u574890.shtml)

c. Lula diz querer eleger alguém para fazer mais do que fez

(Fonte: http://www.estadao.com.br/noticias/nacional,lula-diz-querer-eleger-alguem-para-fazer-maisdo-que-fez,386491,0.htm)

Em (5-17a-c), o C-complemento de dizer aparece na forma de uma oração não-finita com um infinitivo impessoal como núcleo. Embora isso não invalide os dados apresentados na tabela, que mostram uma preferência desse predicado por formas mais finitas, não basta simplesmente analisá-lo de um ponto de vista inerentemente semântico-lexical, sem perceber que, muitas vezes, a realização do complemento como oração finita ou não-finita tem a ver com outro traço semântico da sentença como um todo, no caso, a correferencialidade dos participantes.

Dizer é um exemplo característico dessa relação. Quando não há correferencialidade entre os participantes, esse predicado não licencia complemento não-finito. 
(5-18) meus colegas disseram que eu dei traba::lho que eu comece::i é:: a mexer com o po::vo... (IBORUNA - AC 055: 019)

Em (5-19), a não-correferencialidade entre os participantes da oração matriz (meus colegas) e da oração completiva (eu) impede que o complemento de dizer seja codificado como uma oração com infinitivo como núcleo:

(*5-19) meus colegas disseram que eu dar traba::Iho que eu comece::i é:: a mexer com o po::vo...

Já a correferencialidade entre participantes licencia a codificação do C-complemento de dizer como uma oração finita com indicativo, como em (5-20a), ou como uma oração nãofinita com infinitivo (somente esse tipo de complemento mais nominal é permitido), como em $(5-20 b)$ :

(5-20)a. Inf.1.: -"M.... cê não confia"- ela falô(u) -“não... eu:: o(u) ela vai com o menino ou ela vai comigo"- ela NÃO DE(i)xa ele levá(r) a menina... porque ela diz que num conFIa... UAI é duro uma mãe num confiá(r) num pai c'uma filha é:: é:: é dificil né? (IBORUNA - AI 002:082)

b. Inf.1.: -"M.... cê não confia"- ela falô(u) -"não... eu:: o(u) ela vai com o menino ou ela vai comigo"- ela NÃO DE(i)xa ele levá(r) a menina... porque ela diz não confiar... UAI é duro uma mãe num confiá(r) num pai c'uma filha é:: é:: é dificil né?

Especificamente em relação a dizer, 100\% (11/11) dos casos da amostra aparecem com complementos finitos. Isso seria perfeitamente justificável se, nessas ocorrências, os participantes não fossem correferenciais. Ocorre que, em $73 \%(8 / 11)$ dos casos, os sujeitos são correferenciais, o que licenciaria o uso de uma oração não-finita com infinitivo impessoal como núcleo. Como, porém, essa alternativa não se manifesta, é plenamente justificável dizer, então, que, preferencialmente, seleciona-se o indicativo na codificação da completiva, sejam os participantes correferenciais ou não. Nesses casos, a explicação pode estar relacionada à referência a tempo, modo e aspecto. Se é relevante marcar relações temporais, então, o complemento deve ser codificado como uma oração finita no indicativo. 
O predicado encaixador de enunciação contar tem um uso semelhante a dizer no que diz respeito a C-complementos mais verbais/nominais. Em 100\% (8/8) das ocorrências, o complemento aparece na forma finita no indicativo, mas, diferentemente de dizer, quando um participante de contar é correferencial de um participante de seu complemento (50\% [4/4]), ele não licencia outra forma alternativa. Tal como com dizer, é relevante a marcação temporal da oração completiva em relação à oração matriz. Os exemplos de (5-21a-b) ilustram a ocorrência de contar com complementos finitos cujos participantes são correferenciais e nãocorreferenciais, respectivamente, com o do predicado matriz:

(5-21)a. Inf.: a::i... meu amigo me contou que ele foi:: pra Dis::ney pra:: pousada do Rio Quen::te... lugares assim que eu queria ter ido sa::be?... (IBORUNA - AC 012: 073)

b. Inf.: contaram... que ele tentou assaltar acho que uma:: uma:: acho que uma:: uma loja lá... em Mirassol... uma loja de roupa... então no dia ele tentou assaltar só que aí tinha poli/ Mirassol é pequena... tem polícia né... (IBORUNA - AC 039: 086)

Por outro lado, o corpus não inclui nenhum caso de C-complemento mais nominal, que, ainda assim, é possível nos casos em que, tal como com o predicado encaixador dizer, haja correferencialidade entre participantes:

(5-22) Em entrevista ao $O$ Dia, o cientista político Alberto Carlos Almeida contou acreditar que Gabeira teria tido mais chances se sua campanha tivesse focalizado o eleitor desmotivado, que não estava inclinado a votar.

(Fonte: http://noticias.terra.com.br/eleicoes/2008/interna/0,,OI3285838-EI11874,00

Riotem+maior+indice+de+abstencao+desde.html)

Embora esse tipo de predicado também licencie uma codificação não-finita com infinitivo, quando há correferencialidade entre participantes, a preferência é mesmo por construções finitas no indicativo.

Outro predicado que também traz como complemento, exclusivamente, orações finitas no indicativo (100\% [10/10]) é o verbo falar. Diferentemente de dizer e de contar, com o encaixador falar, a codificação dos participantes não interfere na forma que a completiva assume. Independentemente de serem participantes correferenciais, como em (5-23a), ou não- 
correferenciais, como em (5-24a), o C-complemento requerido deve ser codificado como indicativo, marcando as relações de tempo, modo e aspecto:

(5-23)a. ... e foi muito engraçado ela falou que chegou na escola bem mansinho chegou com quase quarenta minutos de atraso até levou uma bronca né no dia mas que depois ela teve que se justificar para diretora e quando ela começou a contar a história pra diretora a diretora começou a rir... (IBORUNA - AC 088: 217)

*b. ... e foi muito engraçado ela falou chegar na escola bem mansinho chegou com quase quarenta minutos de atraso até levou uma bronca né no dia mas que depois ela teve que se justificar para diretora e quando ela começou a contar a história pra diretora a diretora começou a rir...

(5-24)a. Doc.: cê falou que eles se separaram... cê lembra de alguma coisa assim da separação? (IBORUNA - AC 039: 051)

*b. Doc.: cê falou eles se separarem... cê lembra de alguma coisa assim da separação?

Seguindo o mesmo padrão dos predicados de sua classe, todas as ocorrências do predicado encaixador perguntar (6/6) correspondem a construções completivas no indicativo, do tipo exemplificado em (5-25), sem licenciarem outro tipo de complemento, independentemente de a correferencialidade dos participantes ser positiva (uso pronominal) ou negativa. ${ }^{71}$

(5-25) aí ela:: dona Iracel perguntou se eu queria descer... (IBORUNA - AC 051: 109)

Os resultados relativos aos predicados de enunciação, apresentados nesta seção, podem ser assim sintetizados (com base no corpus e nas possibilidades de ocorrência):

(a) o predicado encaixador determina a forma da completiva na medida em que requerem Ccomplementos finitos no indicativo. Essa constatação é marcadamente notória com os predicados encaixadores dizer, contar, falar e perguntar.

\footnotetext{
${ }^{71}$ Sousa (2007) considera que a oração completiva introduzida pela conjunção se não representa eventos e, assim, nunca equivalerá a um estado de coisas, porque a expressão de um evento implica que uma realidade se instaure, mesmo que apenas na mente dos interlocutores, e a conjunção se não é capaz de instaurar realidades.
} 
(b) subtipos dessa classe de predicados (dizer e contar) podem, no entanto, selecionar a forma não-finita com infinitivo impessoal; nesse caso, o que determina a possibilidade ou não de ocorrência do complemento mais nominal é a correferencialidade dos participantes.

(c) sendo os participantes correferenciais, os subtipos de predicados encaixadores de enunciação acima mencionados admitem tanto formas finitas no indicativo, preferencialmente, quanto formas não-finitas com infinitivo como complementos. Nesses casos, a preferência por formas finitas pode estar relacionada à referência TAM.

Há, assim, casos em que o estatuto semântico do predicado encaixador é suficiente para determinar o tipo de completiva (como, por exemplo, falar e perguntar); há, adicionalmente, casos em que, além da natureza semântica do predicado encaixador, que normalmente seleciona complementos finitos no indicativo, atuam outros aspectos semânticos, igualmente relevantes, tais como compartilhamento de participantes, primeiramente, e referência TAM, posteriormente.

Com base nessa constatação, é possível propor uma escala de tipos morfossintáticos de predicados encaixados para os predicados de enunciação da seguinte forma:

indicativo $>$ subjuntivo infinitivo impessoal em que '>' significa mais requerido do que

\subsubsection{Predicados encaixadores de atitude proposicional}

Predicados encaixadores de atitude proposicional descrevem uma atitude avaliativa do falante em relação à verdade/falsidade da proposição inserida no complemento (cf. 
NOONAN, 1985; DIK, 1997b; CRISTOFARO, 2003). Por sua natureza semântica, requerem um conteúdo proposicional, p-complementos, como construção encaixada.

A Tabela 5-1, na seção anterior, mostra que esse tipo de predicado, tal como os predicados de enunciação, requerem complementos finitos no indicativo em $100 \%$ das ocorrências (16/16). (5-27a-b) ilustram p-complementos com esse tipo de predicado:

(5-27)a. ... acredito que eles conservam muito ma::is as/assim as tradições dos antigos italianos do que os próprios italianos modernos hoje (acho) que eles conservam muito mais... (IBORUNA - AC 084: 205)

b. Inf.: eu não sei sabe eu acho que o::... o espiritismo ele me preencheu... (IBORUNA - AC 100: 386)

É fato que a forma no indicativo é a preferencial para a expressão do complemento. No entanto, não é vedada a ocorrência de complementos mais nominais. Respeitada a correferencialidade entre participantes, alguns subtipos de predicados encaixadores de atitude proposicional podem licenciar o complemento não-finito com infinitivo impessoal, como exemplificam (5-28a-b), que poderiam ter o complemento na forma finita como mostram (529a-b):

(5-28)a. FAB acredita encontrar sobreviventes do voo da Air France

(Fonte: http://www.tvcanal13.com.br/noticias/fabacreditaencontrar-sobreviventes-do-voo-da-airfrance-63822.asp)

b. Aprendam que com time gaúcho não se brinca e que o povo gaúcho honra com seus compromissos, ao contrário desta imprensa júnior paulista que acha saber discutir futebol.

(Fonte: http://blog.miltonneves.ig.com.br/2008/09/21/verdao-quase-lider/)

(5-29) a. FAB acredita que encontrará sobreviventes do voo da Air France

b. Aprendam que com time gaúcho não se brinca e que o povo gaúcho honra com seus compromissos, ao contrário desta imprensa júnior paulista que acha que sabe discutir futebol.

O predicado encaixador acreditar, embora selecione preferencialmente pcomplementos finitos no indicativo, pode também licenciar um complemento mais nominal se 
houver correferencialidade entre os participantes dos dois estados de coisas envolvidos, como em (5-28a). É incontestável, no entanto, a preferência pela forma de indicativo, já que, no corpus analisado, esses predicados selecionam complementos desenvolvidos, independentemente da correferencialidade entre participantes. Além disso, o predicado acreditar expressa a dependência do valor de verdade expresso no complemento e, desse modo, também pode vir complementado por uma oração finita no subjuntivo, como mostra (5-30), em que o fato de o predicado encaixador aparecer negado implica maior grau de não factualidade do complemento:

(5-30) Lula não acredita que Colômbia saia da Unasul

(Fonte:g1.globo.com/NoticiasPolitica/MUL100LULANAOACREDITAQUECOLOMBIASAIAUNASUL)

O predicado encaixador achar, quando sob o escopo de negação, tem um comportamento similar a acreditar. Os p-complementos selecionados são todos finitos no indicativo, o que não impede, entretanto, a ocorrência de p-complemento no subjuntivo, como (5-31), e p-complemento não-finito com infinitivo se houver correferencialidade entre participantes.

(5-31) Bom, acho que é possível. Eu não acho que faça uma música diretamente por política. Eu tive uma participação política em 64, depois não tive mais.

(Fonte: http://www.chicobuarque.com.br/texto/entrevistas/entre_vogue_79.htm)

Como, no corpus analisado, os participantes não são correferenciais, não há possibilidade de licenciar a forma não-finita, mas isso não exclui a possibilidade de construções desse tipo figurarem como complemento de um predicado como achar, como em (5-29b) acima. 
O predicado encaixador pensar tem o mesmo comportamento de acreditar e achar: pode admitir, além do indicativo (5-32d), complementos com subjuntivo (5-32e) e com infinitivo impessoal (5-32f):

(5-32)d. as ve::zes os/ por os alunos tarem pagan::do eles pensam que eles não precisam estuda::r ou que eles não precisam se esforçar porque... (IBORUNA - AC 055: 212)

e. Suzane explicou para a amiga que sua vida mudou depois que deixou de estudar no Colégio Porto Seguro. Contou que descobriu um mundo que jamais pensou que existisse, disse a colega.

(Fonte: http://www.estadao.com.br/arquivo/cidades/2002/not20021110p20984.htm)

f. O Officer Crabtree é, sem dúvida umas das personagens mais apreciadas pelos entusiastas do Allô Allô. A personagem interpretada pelo actor Arthur Bostrom retrata um agente inglês que pensa saber falar francês, e que acaba por fazer uns trocadilhos com a língua inglesa que são de ir às lágrimas.

(Fonte: http://outrasescritas.blogspot.com/2009/11/allo-allo-uma-retrospectiva-iv-arthur.html)

O grau mais próximo do polo da nominalidade que os predicados de atitude proposicional conseguem atingir é na codificação de um complemento na forma não-finita com infinitivo impessoal. Nominalizações não são licenciadas para esse tipo de predicado.

Os resultados relativos aos predicados de atitude proposicional, apresentados nesta seção, podem ser assim sintetizados (com base no corpus e nas possibilidades de ocorrência):

(a) o predicado encaixador determina a forma da completiva na medida em que requerem pcomplementos finitos no indicativo.

(b) o predicado encaixador pode também licenciar a forma no subjuntivo e não-finita com infinitivo impessoal; nesse caso, o que determina a possibilidade ou não de ocorrência do complemento com infinitivo é a correferencialidade dos participantes.

(c) sendo os participantes correferenciais, os predicados encaixadores admitem tanto formas finitas no indicativo, preferencialmente, quanto formas não-finitas com infinitivo como complementos. Nesses casos, a preferência por formas finitas pode estar relacionada à referência TAM. 
Os predicados de atitude proposicional se comportam como os de enunciação nos seguintes termos: o estatuto semântico do predicado encaixador é suficiente para determinar o tipo de completiva; adicionalmente, na seleção de outro tipo de complemento além da forma no indicativo (preferencial), outros aspectos semânticos são relevantes.

Com base nessa constatação, é possível propor uma escala de tipos morfossintáticos de predicados encaixados para os predicados de enunciação da seguinte forma:

indicativo $>$ subjuntivo

infinitivo impessoal

em que '>' significa mais requerido do que

\subsubsection{Predicados encaixadores de conhecimento}

Predicados encaixadores de conhecimento são identificados por descreverem um estado de conhecimento, ou um processo de aquisição (ou perda) de um conhecimento em relação ao fato expresso no complemento oracional (cf. CRISTOFARO, 2003). Os complementos requeridos por esse tipo de predicado designam uma entidade de terceira ordem, isto é, um conteúdo proposicional, visto que, na qualidade de construto mental, as entidades representadas pela completiva não podem ser localizadas nem no espaço nem no tempo e são avaliadas em termos de sua verdade.

Para tratar especificamente da forma como os p-complementos aparecem subordinados ao predicado matriz, considere-se o Gráfico 5-4, que retoma os resultados apresentados na Tabela 5-1 no que diz respeito aos predicados de conhecimento: 


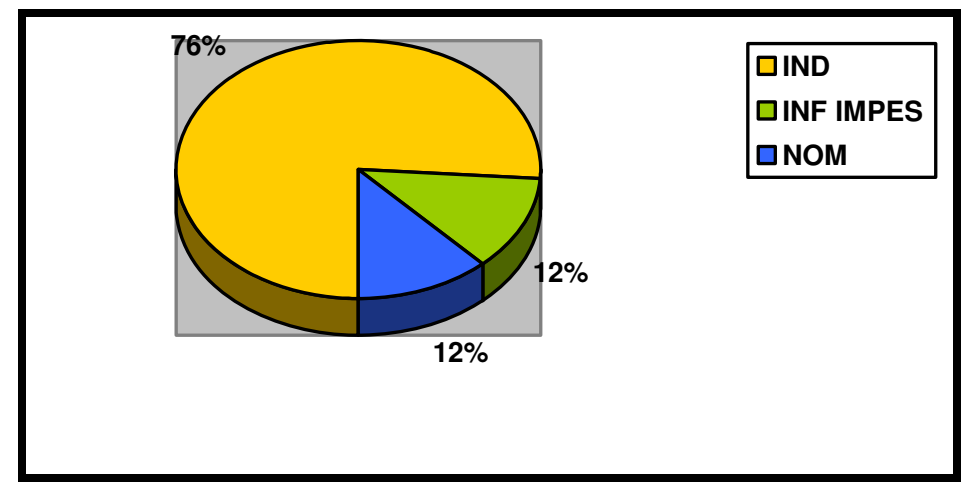

Gráfico 5-4: Predicados de conhecimento e tipos de complementos

O que o Gráfico 5-4 mostra é que predicados encaixadores de conhecimento requerem, majoritariamente, complementos finitos (76\% [24/32]). No corpus analisado, todos os pcomplementos introduzidos por saber, ver, perceber e lembrar são complementos finitos, majoritariamente, no indicativo, como ilustram (5-34a-d), respectivamente:

(5-34)a. e quantas vezes pegamos ele com faca na mão tudo né... a gente num sabia se ele queria matar ele ou matar a gente... então a gente tinha medo né (IBORUNA - AC 132: 075)

b. é menino que qualquer coisinha quer dinheiro... num estuda num leva nada a sério vê que uma coisa errada dá dinheiro rápido vender droga... vender tráfico mexer com droga sei lá... (IBORUNA - AC 024:395)

c. só que só que ela se mandô(u) emBOra... ela quando ela percebeu que eu percebi ela el/ela ligôo(u) p'uns pessoal aqui da maloca dela e foi emBOra foi dormí(r) pra lá... (IBORUNA AI 002:282)

d. ...tinha uma boa:: uma área bastante diversificada e eu lembro que eu gostava muito de andar ali... (IBORUNA - AC 084: 140)

O predicado encaixador de conhecimento saber tem preferência por p-complementos no indicativo e restringe complementos no subjuntivo e no infinitivo. Embora todos as ocorrências encontradas sejam com p-complementos no indicativo, é possível um complemento nominalizado, como mostra (5-35).

(5-35) Lula soube da retirada de nódulo em Dilma há 1 semana.

(Fonte: http://www.estadao.com.br/nacional/not_nac360776,0.htm) 
Segundo Cristofaro (2003), predicados que envolvem percepção mental funcionam como predicados de conhecimento. A autora chama atenção para o fato de, em algumas línguas, o uso de diferentes construções dependentes, estar associado ao sentido do predicado, isto é, se de percepção sensorial ou de conhecimento. É uma distinção que vale para o português. ${ }^{72}$ Quando são predicados de conhecimento, o tipo de complemento requerido é um conteúdo proposicional. $^{73}$

Todos os p-complementos de ver e perceber analisados no corpus tomam um complemento finito como argumento. Contudo, esses predicados podem permitir tanto uma completiva finita no indicativo quanto uma nominalização, isto é, a seleção vai, diretamente, de um extremo ao outro. A restrição, então, é feita somente às formas no subjuntivo e no infinitivo. Observem-se os exemplos dos predicados ver (5-36a-b) e perceber (5-36c-d) com uma completiva nominalizada:

(5-36)a. O Brasil inteiro viu a falência do sistema judiciário, prisional e policial ao mesmo tempo.

(Fonte: http://taruimmastabao.zip.net/)

b. O Brasil inteiro viu que o sistema judiciário, prisional e policial faliu ao mesmo tempo.

c. Tales Ab'Saber vê tentativa de setores desiludidos com o PT de pensar e atuar politicamente fora da esfera dos partidos. Afirma que Lula percebeu a falência do PT e passou a falar diretamente aos pobres, que perderam toda a confiança nas elites.

(Fonte: http://www.midiaindependente.org/pt/red/2006/09/359565.shtml)

d. Afirma que Lula percebeu que o PT faliu.

É possível afirmar, desse modo, que os predicados de conhecimento ver e perceber, tal como o predicado saber, vão, diretamente, do polo mais verbal, representado pelo p-

\footnotetext{
${ }^{72}$ Essas observações poderão ser mais bem analisadas quando somadas às considerações sobre os predicados encaixadores de percepção física, na seção 5.3.6, p. 196.

${ }^{73}$ Dik e Hengeveld (1991) fazem distinção entre predicados de conhecimento, de percepção mental e de percepção direta (física) em sua classificação, como pode ser observado no Capítulo 2, seção 2.3.2 (p. 76). A classificação que apresento aqui está de acordo com a que Noonan (1985) e Cristofaro (2003) apresentam, considerando os predicados que denotam percepção mental como um tipo de predicado de conhecimento, na medida em que, ao se ver/ouvir/perceber/notar um conteúdo proposicional, esse conteúdo passa a fazer parte do conhecimento do experienciador (cf. CRISTOFARO, 2003).
} 
complemento no indicativo, ao polo mais nominal, representado pelo p-complemento na forma de uma nominalização.

As ocorrências com o predicado lembrar também apontam para a seleção de pcomplementos no indicativo, conforme aparece em (5-37a). Esse tipo de predicado pode licenciar, no entanto, construções mais nominais, como o infinitivo (5-37b) e a nominalização $(5-37 b)$ :

(5-37)a. ...tinha uma boa:: uma área bastante diversificada e eu lembro que eu gostava muito de andar ali... (IBORUNA - AC 084: 140)

b. FHC não se lembrou de comentar a queda na desigualdade social do país graças ao governo Lula, não se lembrou de falar do PROUNI, não se lembrou de falar que no governo Lula as classes $D$ e $E$ passaram a ser classe média.

(Fonte: http://dilma13.blogspot.com/2009/11/fhc-o-invejo-surtou.html)

c. Lula lembrou de uma viagem que fez à região, em 1993, quando era apenas presidente nacional do PT, e encontrou-se com Peres e também com o então líder palestino Yasser Arafat.

(Fonte: https://conteudoclippingmp.planejamento.gov.br/cadastros/noticias/2009/11/12/luladefende-visita-de-ahmadinejad)

O predicado esquecer tem um comportamento similar ao de lembrar, admitindo tanto formas mais verbais, como mostra (5-38a), quanto formas mais nominais. No corpus analisado, o tipo de complemento requerido é a oração não-finita com infinitivo e com nominalização, como apresentam (5-38b-c), respectivamente:

(5-38)a. E eu não esqueço a minha origem, e não esqueço que, quando eu deixar de ser presidente, eu voltarei para o meu berço natal, lá dos metalúrgicos do $\mathrm{ABC}$, para continuar vivendo a minha vida.

(Fonte: http://cafe.ebc.com.br/programas/160.2009-10-06.4140476367)

b. Doc.: acham que é uma maravilha né?...

Inf.: e é uma mara/... e é uma maravilha... mas esquece de ver a qualidade... isso prá mim tá sendo de péssima qualidade porque vai formar... péssimos profissionais... (IBORUNA AC 080: 254)

c. aí eu e/ eu esqueço das outras coisas eu esqueço de bagagem eu esqueço de/ de check in de conferência de bilhete esqueço de desembarque esqueço de embarque esqueço de tudo (IBORUNA - AC 051: 366) 
A possibilidade de ocorrer um p-complemento com infinitivo impessoal encaixado nos predicados lembrar e esquecer está relacionada à correferencialidade entre os participantes da oração matriz e da completiva. O falante pode optar por uma construção finita, se pretender marcar a assimetria temporal entre os dois eventos. Isso significa que a condição necessária para haver uma completiva não-finita com infinitivo é a correferencialidade entre participantes e o compartilhamento de referência a tempo, modo e aspecto. Havendo correferencialidade, o que determina a forma da completiva, se complemento finito ou nãofinito, é a referência temporal do evento descrito na matriz e do evento descrito na completiva.

Os resultados sobre os predicados de conhecimento, apresentados nesta seção, podem ser assim sintetizados (com base no corpus e nas possibilidades de ocorrência):

(a) o predicado encaixador determina a forma da completiva na medida em que requer $\mathrm{p}$ complementos finitos no indicativo.

(b) subtipos dessa classe de predicados (ver, perceber, esquecer e lembrar) podem, no entanto, selecionar a forma não-finita com nominalização (é o caso de ver, perceber, esquecer e lembrar) ou com infinitivo impessoal (somente esquecer e lembrar); nesse caso, o que determina a possibilidade ou não de ocorrência do complemento com infinitivo é a correferencialidade dos participantes.

(c) o predicado saber é o único que admite somente p-complementos finitos no indicativo.

Com base nessa dedução, é possível propor uma escala de tipos de predicados encaixados para os predicados de enunciação da seguinte forma: 
indicativo > infinitivo impessoal nominalização

em que '>' significa mais requerido do que

\subsubsection{Predicados encaixadores de volição}

Predicados volitivos descrevem o desejo ou a vontade do participante da oração matriz de que o evento no complemento oracional se realize ou deixe de se realizar (cf. NOONAN, 1985; CRISTOFARO, 2003). Um evento encaixado no predicado querer realiza-se ou não sempre num tempo posterior, identificado como futuro, por isso, identifica-se como nãofactual.

Querer, que é um verbo indicador de modalidade volitiva, diz respeito à necessidade $\mathrm{e}$ à possibilidade, relacionadas ao desejo do falante. Bastos et al. (2007) consideram que esse verbo descreve o desejo do participante de envolver-se com o tipo de estados de coisas designado pelo predicado encaixado (cf. HENGEVELD; MACKENZIE, 2008), além de atuar como um operador modal. A comparação de querer com um operador modal típico como poder, no entanto, permite afirmar que querer pertence a uma classe lexical de palavras, por atuar como predicado, enquanto poder pertence a uma classe gramatical de palavras, por atuar como auxiliar modal (cf. HENGEVELD; MACKENZIE, 2008, p. 401), como mostra o exemplo em (5-41b) em oposição a (5-40b):

(5-40)a. Pedro pode sair hoje.

*b. Pedro pode que Maria saia.

(5-41)a. Pedro quer sair hoje.

b. Pedro quer que Maria saia. 
Para tratar especificamente das possibilidades formais que assumem os complementos, considere-se o Gráfico 5-5, que retoma os resultados apresentados na Tabela 5-1 sobre predicados de volição:

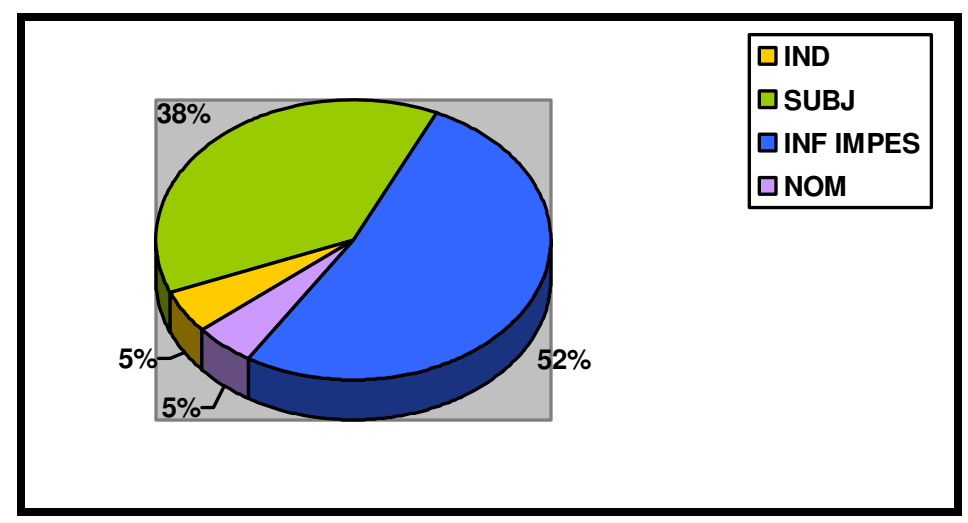

Gráfico 5-5: Predicados de volição e tipos de complementos

Em 57\% (44/84) dos predicados volitivos, o e-complemento assume formas mais nominais, isto é, oração não-finita seja com infinitivo, seja com nominalização. Esse índice aumenta ainda mais se, no âmbito da codificação, o subjuntivo for considerado complemento mais dependente que o indicativo. Os exemplos de (5-42a-c) ilustram, respectivamente, ocorrências desse tipo de predicado com uma oração finita no subjuntivo, com uma oração não-finita com infinitivo e com uma oração não-finita com uma nominalização como núcleo:

(5-42)a. Inf.: ah sempre tinha né? Que:: ela tinha que chegar cedo em casa... e:: num podia né? A mãe dela já num queria que ela chegasse cedo em casa e no começo eu achava até bom né? (IBORUNA - AC 067: 020)

b. Inf.: ... acontece que eu num tô ven(d)o um fim pra minha... (dissertação de mestrado) eu não sei onde eu quero chegá(r)... sabe? eu num tenho... ai eu quero estudá(r) tal coisa eu quero prová(r) tal resultado [(inint.)] (IBORUNA - AI 011: 107)

c. ... e o meu avô éh:: fez com o bolo... paGOU prá confeiteira não deixar o bolo pronto na data... porque ele não queria o casamento... [da filha] (IBORUNA - AC 076: 110)

Um predicado como querer indica semanticamente que o estado de coisas da completiva é posterior ao da matriz e, portanto, não-realizado, dependência que se reflete formalmente no uso de uma codificação subjuntiva ou infinitiva. O não licenciamento formal 
do subjuntivo e de formas não-finitas está relacionado à correferencialidade entre participantes ou à ausência dela. Com participantes correferenciais, emprega-se a forma nãofinita com infinitivo, como em (5-42b), enquanto a falta de compartilhamento conduz esse tipo de verbo a manifestar um e-complemento finito no subjuntivo, como em (5-42a). Parece um tanto óbvio que, se o objeto de desejo estiver na dependência de algum participante que não o próprio indivíduo que manifesta o desejo, representado elo sujeito da matriz, a possibilidade de realização do estado de coisas desejado é mais remoto, por isso o uso do subjuntivo. Para nominalizações, é irrelevante a referência a participantes, ou que a forma nominalizada tenha uma acepção genérica, ou retome um estado de coisas já enunciado previamente. No corpus analisado, predominam formas não-finitas com infinitivo em relação a formas no subjuntivo, em correlação à predominância de compartilhamento de participantes.

Um caso de e-complementos de predicados volitivos com querer codificado como oração finita no indicativo aparece em (5-43):

(5-43) mas eles num querem saber... querem que a gente borda... então cê acaba pegando não... assim... prá prá... éh:: não ser honesta com a pessoa... (IBORUNA - AC 120: 026)

A ocorrência de e-complemento no indicativo, em vez de no subjuntivo, pode ser uma forma de se apresentar o evento descrito na completiva como realis, ou pode representar um registro mais informal de linguagem.

Pretender, um outro tipo de predicado volitivo, a exemplo de querer, ocorre com ecomplementos não-finitos com infinitivo (há somente ocorrências assim no corpus), como em (5-44a), com subjuntivo, como ilustra (5-44b), e com nominalização, como em (5-44c). Similarmente a querer, para a ocorrência da forma não-finita com infinitivo, é necessário o compartilhamento de participantes, indicando a expectativa do participante único em relação à realização do evento designado na completiva: 
(5-44)a. Doc.: e assim... cê Acha importan::te estuDAR cê pretende prestar vestibular? (IBORUNA - AC 012: 257)

b. Lula pretende que o Brasil desenvolva um projeto conjunto com a Argentina na área nuclear.

(Fonte: http://ofca.com.br/artigos/2008/02/29/290208-crise-de-energia-do-presente-e-resolvidacom-projetos-futuros-estranho-nao/)

c. O programa do Governo Lula pretende a construção de mais de um milhão de casas populares, buscando a diminuição do déficit habitacional brasileiro.

(Fonte: http://www.nucleodenoticias.com.br/2009/03/18/prefeitura-quer-se-integrar-ao-programade-moradias-do-governo-lula/)

Os resultados sobre os predicados de volição, apresentados nesta seção, podem ser assim sintetizados (com base no corpus e nas possibilidades de ocorrência):

(a) o predicado encaixador requer majoritariamente e-complementos mais nominais, em especial, complementos não-finitos com infinitivo impessoal.

(b) o predicado encaixador não é o único fator que determina a forma da completiva; a referência a participante é fundamental para determinar a forma que o complemento assumirá, seja como finito no subjuntivo para participantes não-correferenciais, seja como não-finito com infinitivo, para participantes correferenciais.

A seleção do complemento depende, portanto, tanto do valor semântico do predicado encaixador quanto do compartilhamento de participantes. Parece não haver uma relação hierárquica entre predicado encaixador e participantes, já que, para a seleção do tipo de complemento é necessário levar em conta os dois fatores conjuntamente; isso representa o emparelhamento entre o infinitivo impessoal e o subjuntivo, na forma como aparece em (545): 
infinitivo impessoal

$$
>\text { nominalização > indicativo }
$$

subjuntivo

em que '>' significa mais requerido do que

\subsubsection{Predicados encaixadores de manipulação}

Predicados encaixadores de manipulação indicam que a atitude de um indivíduo pode compelir, autorizar ou impedir outro indivíduo de realizar a ação expressa no complemento oracional (cf. GONÇALVES et al., 2008). Givón (1993) alega que, quanto maior o contato direto entre manipulador e manipulado, tanto maior a certeza da contiguidade espacial e temporal dos dois eventos, portanto, tanto maior a possibilidade de serem construídos como um evento único.

Em função dessa possibilidade de expressar a manipulação de ocorrência de determinado evento, o participante da oração matriz exibe necessariamente o traço [+controle]. Entretanto, a ocorrência possível do evento não depende exclusivamente da manipulação de um controlador, podendo envolver também a manipulação possível do participante da oração encaixada. O maior grau de dependência conceitual entre os dois estados de coisas e, portanto, a maior probabilidade de os dois eventos serem concebidos como um único evento complexo implica alegar que é maior a probabilidade de o estado de coisas descrito na completiva receber a configuração formal de oração não-finita. É o que mostra o Gráfico 5-6, que representa visualmente os resultados apresentados na Tabela 5-1: 


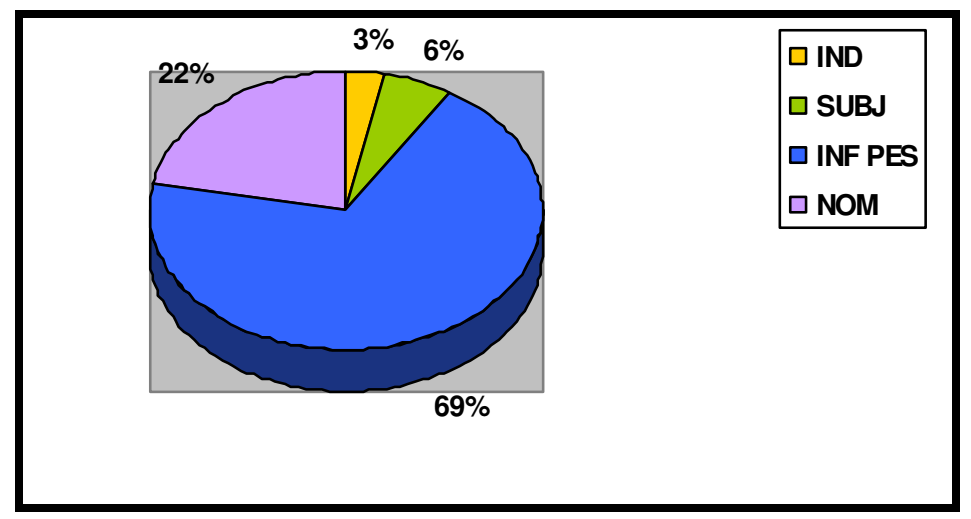

Gráfico 5-6: Predicados de manipulação e tipos de complementos

O Gráfico 5-6 mostra que predicados de manipulação requerem, majoritariamente, ecomplementos mais nominais $(91 \%$ [29/32], interpretado aqui como mais nominais formas de nominalização e infinitivo pessoal). Em comparação ao indicativo, e-complemento com predicado no subjuntivo também representa uma codificação mais dependente. Entre as formas nominais, é a oração não-finita com infinitivo pessoal como núcleo que é a preferida, como (5-46) exemplifica.

(5-46) Inf.: não a mãe dela entrou na briga fez um acordo... falou assim - "não tá bom ela num te pediu então dessa vez você num empresta ou então você deixa ela pegar e pega um dela" - aí parece que ela deixou depois a irmã usar e pegou uma (da minha amiga)... (IBORUNA - AC 024: 153)

A predominância de e-complementos não-finitos não elimina a possibilidade de o ecomplemento ocorrer com uma forma mais verbal que o infinitivo. Nesse caso, como ilustra (5-47), a forma mais verbal escolhida é o subjuntivo, que é também favorecida pela neutralidade do complemento, se é necessariamente realizável ou não, já que pedir não garante a realização da visita.

(5-47) eu pedi que ele fosse me visitar pra que a gente falasse da bíblia... (IBORUNA - AC 124: 011) 
É interessante ressaltar que todas as ocorrências de predicados de manipulação com ecomplemento com infinitivo licenciam também, alternativamente, o uso do subjuntivo. Entretanto, a forma preferencial parece ser mesmo a de infinitivo, que permite sustentar que os dois eventos nas orações matriz e completiva constituem, de fato, um único evento complexo.

Ocorreu somente um caso desse tipo de predicado com um e-complemento finito no indicativo, que licencia tanto o complemento no subjuntivo quanto a forma mais nominal com o infinitivo:

(5-48)a. Inf. 1.: enquanto isso você vai lá no no::... conversá(r) com essa::... m/moça do conselho pra pegá::(r) vê(r) se tem algum documento se ela permite que cê... tira pra xerocá(r) ele (IBORUNA - AI 009:287)

b. Inf. 1.: enquanto isso você vai lá no no::... conversá(r) com essa::... $\mathrm{m} / \mathrm{moça}$ do conselho pra pegá::(r) vê(r) se tem algum documento se ela permite que cê... tire pra xerocá(r) ele

c. Inf. 1.: enquanto isso você vai lá no no::... conversá(r) com essa::... $\mathrm{m} / \mathrm{moça} \mathrm{do} \mathrm{conselho}$ pra pegá::(r) vê(r) se tem algum documento se ela permite tirar pra xerocá(r) ele

No que tange aos tipos de complementos que requerem os predicados encaixadores mandar e pedir, cabe afirmar que, majoritariamente, apresentam complementos mais nominais, ou como orações não-finitas com infinitivo pessoal, que é o caso de mandar, em (549), ou com infinitivo e nominalizações, como ocorre com pedir, em (5-50a-b), respectivamente.

(5-49) eu tava em ca::sa meu pai ligou éh:: meio nervoso assim que tinha acontecido alguma coisa e eu atendi o telefone... aĺ ele mandou eu chamar a minha tia mas eu perguntei o que aconteceu e ele não queira me falar... (IBORUNA - AC 008: 051)

(5-50)a. à noite... chegou três ladrão encapuçado lá... e:: amarraram eles pediram pra eles não abrir a boca que senão ia ficar pior pra eles e eles ficaram muito quieto... (IBORUNA AC 067:086)

b. $\quad 1:$ : ela pegou e contratou mais dois estagiários um mês depois quando ela contratou mais dois estagiários aí no aEroporto uma menina pediu demissão... (IBORUNA - AC 051: 129) 
No corpus analisado, todos os e-complementos de mandar são orações não-finitas com infinitivo pessoal, como exemplificam (5-51a-b). Em todos os casos, seria possível a ocorrência alternativa com orações finitas no subjuntivo, isto é, com complementos mais verbais, mas a preferência indicada na amostra é por complementos mais nominais.

(5-51)a. Inf.1.: falô(u) que ele ficô(u) morren(d)o de vontade de sentá(r) a mão na cara daquele paraguaio nojento né?... só que ele num fez nada só::... mandô(u) o cara... tacá(r) cinza na mão da mãe dele (IBORUNA - AI 008:110)

'a. Inf.1.: falô(u) que ele ficô(u) morren(d)o de vontade de sentá(r) a mão na cara daquele paraguaio nojento né?... só que ele num fez nada só::... mandô(u) que o cara... tacasse cinza na mão da mãe dele

b. eu tava em ca::sa meu pai ligou éh:: meio nervoso assim que tinha acontecido alguma coisa e eu atendi o telefone... aÍ ele mandou eu chamar a minha tia mas eu perguntei o que aconteceu e ele não queira me falar... (IBORUNA - AC 008: 051)

'b. eu tava em ca::sa meu pai ligou éh:: meio nervoso assim que tinha acontecido alguma coisa e eu atendi o telefone... aĺ ele mandou que eu chamasse a minha tia mas eu perguntei o que aconteceu e ele não queira me falar...

Não há nenhuma determinação dos participantes, que são sempre não-correferenciais, na codificação assumida pela completiva. A determinação que há é em relação à referência TAM, codificada pelo predicado matriz. Nesses casos, pode-se dizer que a incidência de construção não-finita no infinitivo está relacionada ao Princípio de Recuperabilidade de Informação (Principle of Information Recoverability, CRISTOFARO, 2003). Segundo esse princípio, a economia sintagmática explica a correlação entre a predeterminação de traços semânticos de estados de coisas ligados e os fenômenos morfossintáticos que levam à não especificação de informação correspondente.

Similarmente a mandar, pedir também requer e-complementos mais nominais, com nominalizações, (5-50b), ou com infinitivo, (5-50a). O grau mais próximo de verbalidade a que essas construções conseguem chegar é a partir do uso do subjuntivo (5-52) e (5-53b), que, em comparação a infinitivos e a nominalizações, é, de fato, mais verbal. 
(5-52) eu pedi que ele fosse me visitar pra que a gente falasse da bíblia... (IBORUNA - AC 124: 011)

(5-53)a. Em discurso na ONU, Lula pede restituição imediata de Zelaya à presidência.

(Fonte: http://noticias.uol.com.br/ultnot/internacional/2009/09/23/ult1859u1490.jhtm)

b. O presidente Luiz Inácio Lula da Silva pediu nesta quarta-feira (23) diante dos líderes mundiais que o presidente deposto de Honduras, Manuel Zelaya, reassuma o cargo imediatamente.

(Fonte: http://noticias.uol.com.br/ultnot/internacional/2009/09/23/ult1859u1490.jhtm)

A amostra registra somente uma ocorrência do predicado encaixador obrigar, que, conforme ilustrado em (5-54a), está codificado com e-complemento infinitivo. Similarmente ao encaixador ordenar, sem ocorrências no corpus, obrigar também licencia construções finitas no subjuntivo (5-54b) e não-finitas com nominalização (5-54c):

(5-54)a então as pessoas às vezes obrigam a gente a esconder que nem tô te falando esconder... os bordados (IBORUNA - AC 120:034)

b. A exigência de Lula obrigou que o Conselho Monetário Nacional (CMN) fizesse reunião extraordinária na semana passada para autorizar que os bancos possam financiar veículos usados.

(Fonte: http://www.nascisul.com.br/noticias/detalhes/bancos-comecam-a-oferecer-o-modercarga)

c. Lula sanciona lei que obriga uso de air bags frontais em carros.

(Fonte: http://www.estadao.com.br/noticias/geral,lula-sanciona-lei-que-obriga-uso-de-air-bags-emcarros,341459,0.htm)

Embora o compartilhamento de participantes se correlacione à finitude das sentenças encaixadas no tocante a vários tipos de construção, esse fator parece não se aplicar a construções com predicados de manipulação. Em função de seu conteúdo, esses predicados, de um modo geral, não encaixam estados de coisas que envolvam o mesmo participante do evento codificado no predicado matriz. A razão, suficientemente óbvia, é a de que atitudes manipulativas são voltadas para o "outro" e raramente para o próprio referente do sujeito autor da manipulação. A dependência conceitual entre os estados de coisas correlaciona-se à 
ocorrência, no corpus analisado, de várias sentenças encaixadas em predicados de manipulação codificadas como não-finitas com infinitivo.

Os resultados sobre os predicados de manipulação, apresentados nesta seção, podem ser assim sintetizados (com base no corpus e nas possibilidades de ocorrência):

(a) o predicado encaixador determina a forma da completiva na medida em que requer majoritariamente e-complementos não-finitos com infinitivo pessoal.

(b) subtipos dessa classe de predicados, como mandar, deixar, podem selecionar de ecomplementos finitos no subjuntivo a construções não-finitas com infinitivo pessoal (forma preferencial). No polo mais nominal, podem selecionar complementos finitos e não-finitos com infinitivo, mas não complementos nominalizados. Uma explicação plausível, que precisa ser checada, é que esses predicados encaixadores requerem complementos representando estados de coisas temporalmente posteriores; nominalizações consistem, em geral, em estados de coisas pressupostos.

(c) subtipos dessa classe de predicados, como pedir e obrigar, podem selecionar de ecomplementos finitos no subjuntivo a construções não-finitas, seja com infinitivo pessoal, seja com nominalizações.

(d) a opção por complementos com infinitivo na codificação não-finita não está relacionada aos participantes, que não são, por definição, correferenciais, mas pode estar relacionada à referência TAM.

Há uma preferência inequívoca por completivas infinitivas. É possível deduzir, portanto, que, a tendência desse tipo de predicado é a de selecionar o infinitivo, embora licencie construções mais verbais e mais nominais que o infinitivo pessoal. A necessidade de marcar o evento denotado pelo verbo como um fato irreal, ou simplesmente possível ou 
desejado (afinal, a ação de manipular não significa que o estado de coisas pretendido se realizou), torna relevante a referência TAM.

Com base nessa afirmação, pode-se propor uma escala de tipos de predicados encaixados para os predicados de manipulação da seguinte forma:

infinitivo pessoal $>$ nominalização $>$ subjuntivo

indicativo

em que '>' significa mais requerido do que

\subsubsection{Predicados encaixadores de percepção física}

Nas diferentes línguas, os complementos de verbos que denotam percepção podem assumir diferentes formas, com diferentes significados, que podem ser interpretados com base no tipo de entidade a que o complemento se refere. Predicados de percepção física indicam que o evento da completiva é objeto da percepção visual (percepção imediata do estado de coisas) do sujeito indicado na oração matriz, o que o difere de um predicado de conhecimento, que denota (o processo de) aquisição do conteúdo expresso no complemento (percepção mental do conteúdo proposicional), tal como os predicados ver e perceber, apresentados na seção 5.3.3 (cf. DIK; HENGEVELD, 1991; CRISTOFARO, 2003). ${ }^{74}$

O contraste entre predicados que denotam uma percepção física e predicados que funcionam como predicados de conhecimento tem atraído a atenção de muitos linguistas (cf. DIK; HENGEVELD, 1991). É essa diferença de significado que pode ser codificada em diferentes tipos formais. Postulo aqui, em conformidade com a proposta de Dik e Hengeveld (1991), Cristofaro (2003) e de Gonçalves (2006), que o complemento de predicados de percepção física tem o estatuto de um estado de coisas (uma entidade de segunda ordem),

\footnotetext{
${ }^{74}$ Cf. nota 73 (p. 183) sobre as classificações de predicado de conhecimento e predicados de percepção mental.
} 
enquanto o complemento de predicados de conhecimento tem o estatuto de um conteúdo proposicional, que designa um fato possível (uma entidade de terceira ordem). Isso significa que predicados como ver e ouvir, dependendo de sua natureza semântica, podem requerer tanto complementos mais verbais, p-complementos, quanto complementos mais nominais, ecomplementos.

Os dados apresentados na Tabela 5-1 mostram que, em oito das dez ocorrências de predicados de percepção física, o e-complemento assume a forma de oração não-finita com infinitivo pessoal. Aos descreverem uma percepção direta, esses encaixadores designam um estado de coisas, que, no caso do português, parece preferir a forma de uma oração não-finita, com infinitivo pessoal, como em (5-56), ou com uma nominalização como núcleo, como em (5-57). A razão dessa distribuição é a de que há maior dependência conceitual entre os estados de coisas da matriz e encaixada, visto que, no mundo real, os estados de coisas de percepção direta e o percebido ocorrem simultaneamente.

(5-56) o rio fica lá na:: no como que fala ali? Nas comporta E... (doc. Ah sim) o rio fica/ a comporta cai no rio (doc.: uhum) quer dizer que nosso rancho fica na represa mesmo acima... então você vai daqui prá lá... você olha a:: as comporta tão aberta... você vê cair no rio... então nós tamos lá na represa mesmo... mas é muito gosTO::SO... (IBORUNA AC 132:203)

De acordo com a PM, um taxista que estava na região e viu o atropelamento seguiu o motorista suspeito depois que ele saiu do local sem prestar socorro à vítima, que morreu no local.

(Fonte: http://g1.globo.com/Noticias/SaoPaulo/0,,MUL1285822-5605,00.html)

É possível alegar, então, que a forma de expressão do complemento de predicados como ver e ouvir, por exemplo, depende da natureza semântica do predicado encaixador, que, por sua vez, pode requerer um conteúdo proposicional, quando tem a função de predicado de conhecimento, ou um estado de coisas, quando indica uma percepção direta. Essa observação está de acordo com a associação que Dik e Hengeveld (1991) e Hengeveld e Mackenzie (2008) estabelecem entre o tipo de complemento e o tipo de entidade designada. 
Sheila saw Peter leave.

Hengeveld e Mackenzie (2008) entendem que a construção em (5-59), finita, descreve a conclusão a que Sheila chegou com base em sua percepção (o fato de Peter não estar no carro, por exemplo), enquanto (5-58), com o complemento não-finito, descreve o estado de coisas diretamente percebido por Sheila. Dik e Hengeveld (1991) formalizam a diferença entre as duas construções alegando que o complemento em (5-59) se identifica com uma pcategoria e o de (5-58), com uma e-categoria. Fica clara a associação entre complementos finitos e percepção mental (predicados de conhecimento), por um lado, e complementos nãofinitos e percepção visual (predicados de percepção física), por outro.

$\mathrm{Na}$ análise dos dados aqui apresentada, mantém-se a relação entre a natureza semântica do predicado e o tipo de entidade designada (p-complemento finitos com predicados de conhecimento e e-complementos não-finitos com infinitivo com predicados de percepção imediata). Observem-se, entretanto, os exemplos em (5-60) e (5-61):

(5-60) Inf.1.: ah depois que abriu essa igreja aí (inint) ((arrastou uma cadeira)) eu também fui lá olhá(r) mas eu desliguei eu já esqueci o arro::z Inf.2: não (isso aí) eu vi que cê desligôo(u) Inf.1: é né? eu/ mas eu fui lá olha de novo (IBORUNA - AI 002:004)

ai mas eu corri grita:ndo e xinga:ndo ... e xinguei tudo quanto é nome MESMO ... e fui atrás mas corri ... corri atrás dele "filha da puta ... vem cá:: ((risos)) eu/ me dá minha chave::... não tem dinheiro aí .. não tem nada::: me dá minha chave" ... e fui correndo ... corri ... corri ... ele pegou e:: ... sabe ... FOI CORRENDO abrindo a bolsinha .... ele viu que não tinha nada ...- tinha um real dos reais -...ele pegou e viu que eu tava corre::ndo ... eu não ia desistir eu ia correr atrás dele até o/ até quando eu conseguir ... aí ele pegou e:: jogou a bolsinha n/no chão ... com a chave tudo ... (IBORUNA - AC 062:99)

A ocorrência (5-60) foi analisada como um caso de p-complemento finito, isto é, complementos de predicados de conhecimento que designam um conteúdo proposicional. A leitura possível de (5-60) é a de que o Informante 2, ao dizer que viu o Informante 1 desligar o fogão, revela ter visto tão somente o fogo apagado, inferindo, portanto, que o Informante 1 
teria desligado o fogão. No entanto, não é impossível uma leitura que o Informante 2 tenha de fato presenciado a ação do Informante 1 de apagar o fogo, alternativa que permitiria classificar o complemento finito como e-complemento.

$\mathrm{Na}$ interpretação de (5-61), esse valor é facilmente notável, por ser a percepção do assaltante física, visual e não mental. Essa leitura permite sustentar o postulado de que, no português, diferentemente do que defendem Hengeveld e Mackenzie (2008), bem como Dik e Hengeveld (1991), é possível a um predicado encaixador de percepção visual licenciar complementos mais verbais, no caso e-complemento finito no indicativo. A despeito dessa possibilidade, a preferência nos dados é mesmo por e-complementos não-finitos (80\% [8/10]).

Os resultados sobre os predicados de percepção física, apresentados nesta seção, podem ser assim sintetizados (com base no corpus e nas possibilidades de ocorrência):

(a) a natureza semântica do predicado encaixador determina a forma da completiva. Há uma preferência para que o e-complemento assuma a codificação morfossintática de oração nãofinita com infinitivo pessoal.

(b) o predicado encaixador de percepção física pode ser suficiente para determinar o tipo de completiva; além do predicado encaixador, que normalmente seleciona complementos nãofinitos com infinitivo pessoal, o falante pode optar por marcar a oração dependente com TAM, casos em que opta por uma oração mais verbal. Com os predicados de percepção física, há um grau de maior dependência conceitual entre os estados de coisas, visto que, no mundo real, a percepção e o evento percebido se realizam simultaneamente.

Os resultados permitem propor uma escala de tipos de predicados encaixados da seguinte forma (com base no corpus e nas possibilidades de ocorrência): 
infinitivo pessoal > nominalização

indicativo

em que '>' significa mais requerido do que

\subsubsection{Predicados encaixadores fasais}

Predicados encaixadores fasais se referem à fase de desenvolvimento (início, continuação, fim) do estado de coisas por eles designados. De acordo com Dik (1997a), esses predicados tomam um complemento que descreve um estado de coisas necessariamente simultâneo ao estado de coisas descrito na oração matriz. O estado de coisas designado pela completiva está em determinada fase em relação à evolução temporal do estado de cosias designado pela oração matriz.

Cristofaro (2003) considera que há uma relação de interconexão que se estabelece entre o predicado fasal e a oração dependente: começar, continuar ou parar uma ação é, na verdade, parte da ação. Por isso, predicados fasais agem como se fossem operadores aspectuais do estado de coisas dependente, mas têm um comportamento diferente do deles.

A GF (DIK, 1997a, 1997b) considera que os fasais são operadores que modificam a estrutura interna do estado de coisas a que eles se referem. Na medida em que especifica a fase de desenvolvimento de um estado de coisas, os predicados fasais modificam a constituição interna do estado de coisas dependente, e, desse modo, poderiam ser considerados operadores aspectuais. Entretanto, como observado por Siewierska (1991 apud CRISTOFARO, 2003), predicados fasais operam de modo bastante diverso dos outros operadores aspectuais, como, por exemplo, o perfectivo/imperfeito. Enquanto a distinção perfectivo/imperfectivo é puramente interna ao estado de coisas afetado, predicados fasais, por outro lado, relacionam o estado de coisas que eles modificam, tomado como um todo, a 
outro estado de coisas, a saber, o fato de que uma certa entidade se encontra numa certa fase com respeito à realização do estado de coisas em si mesmo. A constituição temporal interna desse estado de coisas não é afetada pelo operador aspectual (cf. CRISTOFARO, 2003).

Com base nessas observações, é possível, então, uma análise que considere os fasais verdadeiros encaixadores, e não operadores de aspectualidade. A diferença entre predicado fasal e operadores aspectuais, como o perfectivo/imperfectivo, pode ser observada por uma comparação entre (5-63a-b):

(5-63)a. O pedreiro começou a trabalhar.

b. O pedreiro está trabalhando agora.

O enunciado de (5-63b) especifica que a ação de trabalho está em curso, mas não há nenhuma referência à fase em que o pedreiro se encontra no que diz respeito ao desenvolvimento da ação (por exemplo, ele pode ter apenas começado a trabalhar, ou estar no final do trabalho), diferentemente de (5-63a), em que começar especifica o início do evento de trabalhar. Além disso, observe-se que, para atuar como verdadeiros operadores aspectuais, começar, parar e continuar não poderiam ser classificados como classes lexicais de palavras em português, mas como classes gramaticais de palavras na qualidade de verbos auxiliares. Para tanto, não é absolutamente clara a possível auxiliaridade desses predicados, que preservam o valor semântico de verdadeiros predicados intransitivos (5-64a) e transitivos causativos (5-64b).

(5-64)a. O trabalho do pedreiro começou.

b. O pedreiro começou o trabalho. 
Além dessa evidência no português, há evidências tipológicas de que o grego é um bom testemunho de que predicados fasais assumem uma construção completiva verbal, como se observa em (5-65):

$$
\begin{array}{lll}
\text { Sinéxyse } & \text { [na } & \text { katevéni]. } \\
\text { continuar.PFV.3.SG } & \text { CONJ } & \text { descer.IMPF.3.SG }
\end{array}
$$

'Ele continuou descendo’. $\quad$ (Adaptado de Hengeveld e Mackenzie, 2008, p. 366)

Há, no entanto, outras línguas em que, para se expressar noções fasais, é necessário acrescentar afixos verbais, como no groenlandês ocidental em (5-66):

$$
\begin{aligned}
& \text { akiuti-usaar-puq } \\
& \text { resist-keep.on-3SG:INDC }
\end{aligned}
$$

'Ele continuou resistindo.'

(Adaptado de CRISTOFARO, 2003, p. 103)

O fato é que há línguas que dispõem de predicados fasais, como o português, e outras que não dispõem - e marcam as noções fasais de um outro modo, tal como o groenlandês ocidental, que se vale de afixos verbais. Mutatis mutandis, há línguas em que os modais são verdadeiros predicados encaixadores. Há outras línguas, como o português, em que eles funcionam como verbos auxiliares e, como tais, constituem classes gramaticais de palavra. ${ }^{75}$

Bastos et al. (2007, p. 210) consideram que um predicado fasal "indica que a propriedade de 'ter um começo', 'ter um fim' ou 'ter uma continuidade' se aplica ao evento encaixado no predicado". ${ }^{76} \mathrm{Na}$ análise que os autores fazem, os complementos desse tipo de predicado são classificados como uma propriedade, isto é, como um f-complemento, quando a completiva é uma oração não-finita com infinitivo ou com gerúndio. Hengeveld e

\footnotetext{
${ }^{75}$ Cf. Quadro 2-6, Capítulo 2, seção 2.3 .2 (p.83).

${ }^{76} \mathrm{Cf}$. original: To indicate that the property of 'to have a beginning', 'to have an end' and 'to have continuity' applies to the event embedded in the predicate.
} 
Mackenzie (2008) também sustentam o argumento de que os fasais são predicados e, como tais, classes lexicais de palavra que tomam um f-complemento.

Como mencionado, a GF (DIK, 1997a, 1997b) considera o que aqui se chama predicados fasais como operadores que modificam a estrutura interna do estado de coisas a que eles se referem e, por isso, atuam, na primeira camada (predicados e termos, na versão standard do modelo). Essa posição parece se manter no novo modelo, já que Hengeveld e Mackenzie (2008) tratam o complemento de um predicado fasal como f-complemento, isto é, uma propriedade (que equivaleria à primeira camada na versão padrão do modelo). É possível que essa associação tenha diretamente a ver com o fato de predicados fasais sempre tomarem infinitivo como complemento, tipo de predicado que é identificado por Hengeveld e Mackenzie (2008) como propriedades.

Na medida em que o estado de coisas principal não tem uma referência puramente interna ao estado de coisas relevante (como acontece com os operadores aspectuais), postulo que os predicados encaixadores fasais do português designam entidades de segunda ordem, isto é, estados de coisas, e não uma propriedade, como defendem Bastos et al. (2007) e Hengeveld \& Mackenzie (2008). Essa posição é sustentada por Cristofaro (2003), que acha problemático postular que a atuação dos predicados fasais se dá no nível do predicado e não no nível da predicação.

$\mathrm{Na}$ análise dos dados, predicados fasais estão associados a e-complementos nãofinitos com infinitivo impessoal, como em (5-67), e a e-complementos não-finitos com nominalização, como em (5-68). ${ }^{77}$ No corpus, $95 \%$ (92/97) dos complementos de fasais são codificados como formas não-finitas com infinitivo.

\footnotetext{
${ }^{77} \mathrm{O}$ fato de os predicados fasais também selecionarem nominalizações como complemento é mais uma razão para considerar as completivas de predicados fasais como e-complementos e não f-complementos, já que não seria possível considerar um complemento nominalizado (derivado de verbo) como uma propriedade.
} 
(5-67) Inf.: ai às vezes eles fazem joguinho prá gente ficar cansado depois... éh:.... ele/ éh tacar um prá outro... o goleiro/ o::/ o::... guarda-campo taca pro ou/ pro time dele e aí ele/ a ge/ a gente fica tacando aí a gente fica cansado eles começam a queimar todo mundo do outro time inimigo... (IBORUNA - AC 004: 163)

(5-68) ::... e ele tava no ônibus e quando ele sentou... ele sentou numa coisa da/ na cade::ira... e sentou e até cont/ e continuou a via::gem... vindo de São José do Rio Preto pra Bady Bassit... (IBORUNA - AC 035: 160)

Observe-se, agora, o exemplo contido em (5-69):

(5-69) Doc: Qual seria a tradução direta desse 'headhunter'?

Inf 2: éh, éh... seria um contato direto... é e/ eles telefonam... falam... com a pessoa... através de uma mensagem... que que de modo nenhum pode ser identificada porque começa que a pessoa pode estar muitíssimo bem no lugar que está e de maneira nenhuma pensando em sair... então...o telefonema de alguém ah... intermediário de um concorrente pode complicar a situação da pessoa naquela empresa... (D2 SP 360)

Como observam Bastos et al. (2007, p. 209), nesse caso, “o verbo começar pode, no seu uso, ser considerado um encaixador de complemento alternativo a modificadores adverbiais, como primeiramente e em primeiro lugar". Bastos et al. (2007) entendem que, no exemplo em (5-69), começar toma um A-complemento, isto é, um ato que, juntamente com os outros atos, integram um move, em reação à pergunta feita pelo documentador.

Em (5-69), começar introduz um dos argumentos em defesa da ideia de que uma empresa, interessada em contratar o funcionário de outra empresa, faz um contato por telefone, sem qualquer identificação. Na sequência, o falante expõe o segundo argumento - $e$ de maneira nenhuma (pode estar) pensando em sair. E conclui a série de estados de coisas iniciados por começar com então... o telefonema de alguém ah... intermediário de um concorrente pode complicar a situação da pessoa naquela empresa.

A ocorrência de um predicado 'fasal' com um complemento finito identifica um valor para começar que é diferente do valor característico desse tipo de predicado. Os predicados fasais característicos, como os da amostra analisada, designam estados de coisas. Ao encaixar uma completiva finita, a base é a mesma, mas a noção fasal normal, aqui preservada, abrange 
uma camada acima da do estado de coisas por dar início ao primeiro argumento de uma discussão ou de um episódio tipicamente argumentativo. Esse uso extrapola o sentido original, como uma extensão metafórica, como se o falante assinalasse que o primeiro argumento é o mais importante.

Diferentemente da interpretação de Bastos et al. (2007), prefiro classificar o tipo de complemento em (5-69) como e-complemento. De um modo amplo, os estados de coisas que fazem parte de um discurso compõem um episódio, definido pela GDF como um conjunto coerente de estados de coisas. Cada estado de coisas constitui, então, parte de um episódio, ou é, em si mesmo, um episódio, na medida em que aparece com tempo verbal absoluto (HENGEVELD; MACKENZIE, 2008). Na análise aqui proposta, seria possível a classificação do complemento em (5-69) como ep-complemento (assim como seria possível a classificação de todos e-complementos como ep-complemento), no sentido mais amplo que a relação entre estado de coisas e episódio toma nos termos da GDF. Nesse caso, o que postulo é que esse exemplo inovador de começar não sai do âmbito do Nível Representacional.

Os resultados sobre os predicados fasais, apresentados nesta seção, podem ser assim sintetizados:

(a) o predicado fasal admite tanto formas infinitivas quanto nominalizações como complemento e restringe formas mais verbais, seja no indicativo, seja no subjuntivo.

(b) começar, terminar, acabar, em casos particulares, admitem a ocorrência de um complemento finito no indicativo, como codificação alternativa a modificadores adverbiais.

Os resultados permitem propor uma escala de tipos de predicados encaixados da seguinte forma (com base no corpus): 
infinitivo impessoal > nominalização

em que '>’ significa mais requerido do que

\subsubsection{Predicados encaixadores de experiência psicológica}

Predicados encaixadores de experiência psicológica representam, juntamente com os predicados fasais, já mencionados, e com os de tentativa, a serem apresentados, o polo mais nominal na classificação de predicados encaixadores e tipos de completivas analisadas neste trabalho. Como apresentado na Tabela 5-1, esse tipo de predicado requer exclusivamente ecomplementos não-finitos com infinitivo (100\% [25/25]).

(5-71) Inf.: olha eu gosto muito assim de trabalhar na cidade eu gosto no final de semana no domingo... (IBORUNA - AC 067: 168)

Embora não tenha havido ocorrência no corpus, o predicado de experiência psicológica gostar admite e-complementos com nominalização, como em (5-72):

(5-72) Jucá diz que Lula gostou da indicação de Lobão para Minas e Energia.

(Fonte: http://www1.folha.uol.com.br/folha/brasil/ult96u362452.shtml)

$\mathrm{O}$ fato de predicados de experiência psicológica aparecerem majoritariamente com complementos não-finitos com infinitivo impessoal está relacionado ao compartilhamento de informações, tanto em relação ao participante, que é correferencial, quanto em relação à referência a TAM. Para a ocorrência de completivas no indicativo (5-73a-b) e no subjuntivo (5-73c-d) não pode haver compartilhamento de participante. Nas ocorrências de (5-73a-d), a variação é possível porque não há diferença semântica em relação à factualidade do predicado encaixado, embora seja normativamente prescrita a codificação de subjuntivo, que, nessa situação, seria morfossintaticamente determinada. O compartilhamento de informação 
referente a participante e, consequentemente, a TAM determina a forma que a completiva assumirá, finita ou não-finita com infinitivo.

(5-73)a. Mas o que eu estranho é que a Abin, depois que eu disse isso ao presidente Lula, parte para mandar arapongas contra o PTB. Alguém, dentro do governo, não gostou que nós passamos essa informação ao presidente Lula.

(Fonte: http://www.observatoriodaimprensa.com.br/artigos.asp?cod=333ASP002)

b. PT não gostou que o PSDB ficou com a presidência.

(Fonte: http://www.jhoje.com.br/04032008/geral.php)

c. Solnik conta que Borgneth se contrariou com o depoimento do ex-deputado Airton Soares, que teve de deixar o PT porque votou em Tancredo Neves. Não gostou que Fafá de Belém contasse o boicote que Franco Montoro tentou impor-lhe, nem de Mário Covas Neto dizendo que hoje o PT está à direita do PSDB.

(Fonte: http://observatorio.ultimosegundo.ig.com.br/artigos.asp?cod=281ASP003)

d. O presidente Luiz Inácio Lula da Silva usou ontem as solenidades do Programa de Aceleração do Crescimento (PAC), em Belo Horizonte e Ribeirão das Neves, na região metropolitana, para mais uma vez negar que esteja utilizando suas viagens pelo País para fazer campanha eleitoral. "A minha oposição não gosta que eu ande. Ela fala que eu estou fazendo campanha. Eu não sou candidato..."

(Fonte: http://www.cut.org.br/content/view/1148/170/)

Os resultados sobre os predicados de experiência psicológica, apresentados nesta seção, podem ser assim sintetizados (com base no corpus e nas possibilidades de ocorrência):

(a) o predicado encaixador requer majoritariamente e-complementos mais nominais, em especial, complementos não-finitos com infinitivo impessoal.

(b) a natureza semântica do predicado encaixador não é o único fator que determina a forma da completiva; a referência a participante é fundamental para determinar a forma de codificação da completiva, seja finita, para participantes não-correferenciais, seja não-finita com infinitivo, para participantes correferenciais. 
(c) como a referência tempo-aspectual do predicado encaixado é simultânea à da matriz, o subjuntivo, normativamente prescrito, é preferível na oração completiva, situação que indica um tipo de determinação estritamente morfossintática. ${ }^{78}$

Pode-se propor a seguinte escala de tipos de predicados encaixados para os predicados de experiência psicológica:

infinitivo impessoal

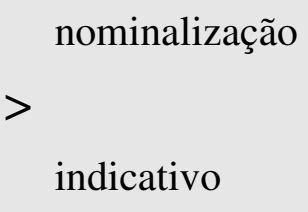

subjuntivo

em que '>' significa mais requerido do que

\subsubsection{Predicados encaixadores de tentativa}

Predicados de tentativa indicam que o participante do estado de coisas principal emprega meios para realizar/conseguir que o estado de coisas descrito no complemento oracional ocorra. No corpus analisado, esse tipo de predicado restringe-se à ocorrência de tentar e de procurar, que, em 100\% (14/14) das ocorrências, licenciam um complemento nãofinito com infinitivo impessoal.

Juntamente com predicados de percepção imediata e de experiência psicológica, predicados de tentativa são os que mais restringem a ocorrência de um estado de coisas com um complemento não-finito. Além disso, os estados de coisas, tanto do predicado encaixador quanto do predicado da completiva, estão codificados em um único evento, o que se reflete na codificação não-finita do complemento:

\footnotetext{
${ }^{78} \mathrm{O}$ uso do indicativo em vez do subjuntivo não tem qualquer motivação pragmática ou semântica; é, na realidade, o produto de processos sociolinguísticos de variação e mudança.
} 
(5-75)a. Inf.: contaram... que ele tentou assaltar acho que uma:: uma:: acho que uma:: uma loja lá... em Mirassol... uma loja de roupa... então no dia ele tentou assaltar só que aí tinha poli/ Mirassol é pequena... (IBORUNA - AC 039: 087)

b. Inf.: não ela foi na casa da:: irmã dela... procurou saber onde eu morava e começamos a namorar... (IBORUNA - AC 145:045)

O comportamento desse tipo de predicado manifesta o princípio givoniano de que, quanto mais integrados os eventos, tanto em relação à correferencialidade entre participantes quanto em relação a TAM, mais nominal o complemento. Essa natureza tão integrada entre predicado encaixador e predicado encaixado pode levar, inclusive, à omissão da forma nãofinita, nas situações em que o verbo da dependente for [+ dinâmico] e [+ controlado], como fazer ou dar:

(5-76)a. Ela [Carmo] tentou (dar) um risinho impudico, sem resultado (DM, 229)

(Retirado de BORBA, 1990, p. 1284)

b. Seu vigário, me desculpe, mas eu tentei (fazer) de tudo (PP, 99)

(Retirado de BORBA, 1990, p. 1284)

Embora não tenha ocorrido no corpus, o predicado encaixador tentar também é compatível com construções ainda mais nominais, com nominalizações como núcleo, como ilustra (5-77):

(5-77) Estimulado por alguns de seus ministros, Lula tentou a aproximação dos dois partidos em vários momentos.

(Fonte: http://abcpolitico.com.br/index.php?secao=secoes.php\&sc=5\&url=cenario_politico.php)

O predicado encaixador de tentativa não licencia a codificação morfossintática da completiva na forma de complementos mais verbais, seja no indicativo, seja no subjuntivo.

Os resultados sobre os predicados de tentativa, apresentados nesta seção, podem ser assim sintetizados (com base no corpus e nas possibilidades de ocorrência): o predicado 
encaixador determina a forma da completiva na medida em que requer majoritariamente ecomplementos não-finitos com infinitivo impessoal e, alternativamente, nominalizados.

Com base na discussão aqui apresentada, propõe-se a seguinte escala de tipos de predicados encaixados:

infinitivo impessoal > nominalização em que '>' significa mais requerido do que

\subsubsection{Sumário geral}

As seções anteriores apresentaram uma descrição geral das subordinadas completivas com base no tipo de predicado encaixador e no tipo de unidade semântica que os complementos representam. Os dados analisados mostram haver uma relação entre o tipo de construção encaixada e o estatuto semântico do predicado encaixador, que pode interferir no comportamento das orações completivas, determinando sua forma de expressão.

O Gráfico 5-1, repetido aqui por conveniência, mostrou que há um declínio no grau de verbalidade do complemento em oposição a um aumento no grau de nominalidade do polo esquerdo para o polo direito, isto é, dos predicados de enunciação em direção aos predicados de tentativa. 


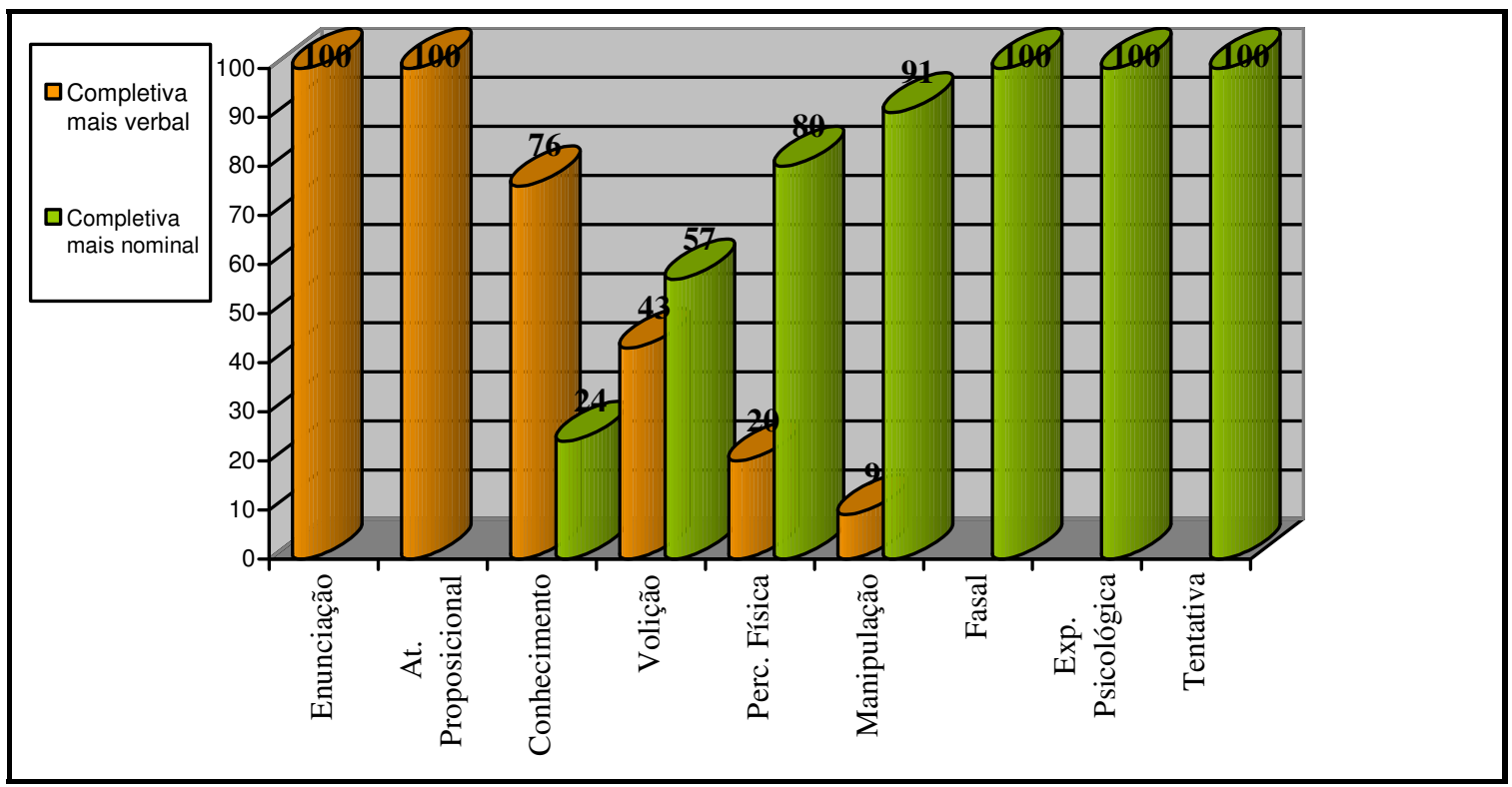

Gráfico 5-1: Tipos de predicado encaixador e tipos de complemento

Os predicados de enunciação, de atitude proposicional e de conhecimento são os que requerem exclusiva ou majoritariamente completivas mais verbais, com verbo no indicativo como núcleo. Isso não significa, no entanto, que esses predicados não licenciem também complementos mais nominais.

Predicados de enunciação podem também admitir complementos no subjuntivo e, em alguns casos, uma forma infinitiva como C-complemento, conforme traços de subcategorização semântica do predicado encaixador. Em casos de correferencialidade entre participantes, o falante pode optar por um complemento finito, quando for relevante assinalar referência TAM, ou por um complemento não-finito, quando não é relevante essa marcação.

Predicados de atitude proposicional requerem majoritariamente p-complementos com verbos finitos no indicativo. Os predicados achar, acreditar e pensar licenciam também complementos no subjuntivo e formas ainda mais nominais, como o infinitivo impessoal.

Seguindo a tendência de predicados encaixadores que requerem orações completivas mais verbais, predicados de conhecimento requerem majoritariamente p-complementos com verbos finitos. Os encaixadores saber, lembrar, esquecer, ver e perceber requerem pcomplementos com verbos finitos, no indicativo, preferencialmente. Os encaixadores lembrar 
e esquecer podem licenciar complementos ainda mais nominais, ou seja, formas não-finitas com infinitivo impessoal ou com nominalização. Já os encaixadores saber, ver e perceber licenciam uma nominalização, além da forma preferencial no indicativo.

Similarmente a predicados encaixadores de enunciação, de atitude proposicional e de conhecimento, que, embora admitam majoritariamente complementos verbais, licenciam também complementos mais nominais, predicados de volição e de manipulação requerem majoritariamente e-complementos nominais (preferencialmente com infinitivo), mas admitem também complementos codificados na forma finita, no subjuntivo ou no indicativo. Tanto predicados de volição quanto de manipulação apresentam poucas ocorrências de ecomplementos finitos no indicativo, requerendo majoritariamente formas no subjuntivo. Predicados volitivos restringem-se, especificamente, à ocorrência de e-complementos no subjuntivo, quando não dispõem de compartilhamento de participantes, que, portanto, não podem ser correferenciais, condição que licencia somente formas não-finitas.

Com predicados encaixadores de manipulação, a codificação de participantes, que são, por definição, exclusivamente não-correferenciais, não interfere na escolha de um ecomplemento finito no subjuntivo: nesse caso, o uso preferencial da forma não-finita parece estar relacionado às referências a tempo, modo e aspecto, visto que o compartilhamento desse tipo de informação permite conceber os eventos descritos na matriz e na subordinada como fundidos num único. Os predicados encaixadores mandar e pedir também requerem complementos mais nominais, não admitindo, portanto, complementos finitos no indicativo. O grau mais próximo da verbalidade que esses complementos conseguem atingir é o da codificação do complemento com verbo finito no subjuntivo.

Predicados encaixadores de percepção física requerem e-complementos mais nominais, isto é, formas não-finitas com infinitivo pessoal, preferencialmente, ou nominalização, mas também admitem formas mais verbais, no indicativo. 
$\mathrm{Na}$ direção ao extremo em que os predicados encaixadores requerem complementos mais nominais, no Gráfico 5-1, predicados fasais, de experiência psicológica e de tentativa identificam-se como requerendo preferencialmente e-complementos nominais, não-finitos com infinitivo e nominalização. Complementos finitos no indicativo não são licenciados para predicados encaixadores fasais e de tentativa. Formas finitas no indicativo e no subjuntivo, no entanto, podem aparecer como complemento para os predicados de experiência psicológica, casos em que é relevante observar que participantes não podem ser correferenciais.

As possibilidades de cada tipo de predicado selecionar complemento estão resumidas no Quadro 5-2. ${ }^{79}$

\begin{tabular}{|l|l|l|l|l|l|}
\cline { 2 - 6 } \multicolumn{1}{c|}{} & \multicolumn{1}{c|}{ IND } & \multicolumn{1}{c|}{ SUBJ } & \multicolumn{1}{c|}{ INF. PESS } & INF. IMPESS & \multicolumn{1}{c|}{ NOM } \\
\hline de Enunciação & C-complemento* & C-complemento & & C-complemento & \\
\hline de At. proposicional & p-complemento* & p-complemento & & p-complemento & \\
\hline de Conhecimento & p-complemento* & & & p-complemento & p-complemento \\
\hline de Volição & e-complemento & e-complemento* & & e-complemento* & e-complemento \\
\hline de Manipulação & e-complemento & e-complemento & e-complemento* & & e-complemento \\
\hline $\begin{array}{l}\text { de Experiência } \\
\text { psicológica }\end{array}$ & e-complemento & e-complemento* & & e-complemento* & e-complemento \\
\hline de Percepção física & e-complemento & & e-complemento* & & e-complemento \\
\hline Fasais & & & & e-complemento* & e-complemento \\
\hline de Tentativa & & & & e-complemento* & e-complemento \\
\hline
\end{tabular}

Quadro 5-2: Tipo de predicado encaixador e tipo de complemento

*Forma preferencial ${ }^{80}$

Chama a atenção que complementos pertencentes às camadas mais altas de representação, como conteúdo comunicado e conteúdo proposicional, licenciam formas

\footnotetext{
${ }^{79}$ Cabe relembrar a taxonomia para a referência aos tipos de completivas, apresentada no início deste capítulo: C- complemento para conteúdos comunicados, p-complemento para conteúdos proposicionais e e-complemento para estados de coisas (cf. HENGEVELD; MACKENZIE, 2008).

${ }^{80}$ Os predicados encaixadores que aparecem no Quadro 5-2 como tendo duas formas preferenciais (de volição e de experiência psicológica) são aqueles em que se deve observar a correferencialidade ou não do participante para determinar a forma da completiva. No corpus, houve maior predominância de complementos não-finitos com infinitivo em relação ao subjuntivo e isso se deve à correferencialidade de participantes. Em outras palavras, tanto o subjuntivo quanto o infinitivo podem ser preferenciais porque, para determinar qual forma será escolhida, é necessário verificar se os dois estados de coisas envolvidos compartilham ou não participantes.
} 
nominais (não-preferenciais) e complementos pertencentes às camadas mais baixas de representação, como estado de coisas, permitem formas mais verbais (também nãopreferenciais), sobretudo o indicativo. Não é possível afirmar, desse modo, que, no português brasileiro, predicados como os de enunciação, de atitude proposicional e de conhecimento não envolvam integração semântica, tal como alega Cristofaro (2003) em seu estudo tipológico. Essas observações serão mais bem tratadas no próximo capítulo.

\subsection{A determinação de participantes e referência TAM na seleção da completiva}

Esta seção mostra os resultados referentes à integração semântica das completivas ao predicado encaixador, com base em critérios definidos por Cristofaro (2003) e Givón (1980, 1993), tais como a correferencialidade entre participantes e a referência a categorias de tempo, modo e aspecto.

Postulo que são mais integrados os eventos com compartilhamento de marcação TAM, uma vez que a cotemporalidade sinaliza eventos cognitivamente adjacentes. ${ }^{81}$ Assim, a completiva de maior grau de integração tende a apresentar a mesma relação temporal que a oração matriz, o que é observado principalmente nas completivas não-finitas com infinitivo como núcleo, que, por não apresentarem referência TAM distinta do verbo da matriz, tendem a formar com ela um evento único.

Observe-se a Tabela 5-3, que apresenta resultados referentes a relações temporais:

\footnotetext{
${ }^{81}$ Vale lembrar que marcação TAM é mais abrangente que cotemporalidade. No entanto, se, por um lado, a referência aspectual está fortemente conectada à referência temporal na morfossintaxe do português, a referência modal, por outro, está ligada, às vezes, à factualidade do evento, e, às vezes, está ligada exclusivamente ao grau de dependência da completiva em relação à predicação matriz.
} 
Tabela 5-3: Tipo de predicado encaixador e relações temporais

\begin{tabular}{|c|c|c|c|c|c|c|c|c|}
\hline \multirow[t]{2}{*}{ Predicado encaixador } & \multicolumn{2}{|c|}{ Anterioridade } & \multicolumn{2}{|c|}{ Simultaneidade } & \multicolumn{2}{|c|}{ Posterioridade } & \multicolumn{2}{|c|}{ Total } \\
\hline & $\mathrm{N}$ & $\%$ & $\mathrm{~N}$ & $\%$ & $\mathrm{~N}$ & $\%$ & $\mathrm{~N}$ & $\%$ \\
\hline de Enunciação & 36 & 100 & & & & & 36 & 11 \\
\hline de At. proposicional & 9 & & & & 7 & & 16 & 5 \\
\hline de Conhecimento & 26 & & 4 & & 2 & & 32 & 9 \\
\hline de Volição & & & & & 84 & 100 & 84 & 24 \\
\hline de Manipulação & & & & & 32 & 100 & 32 & 9 \\
\hline de Exp. psicológica & & & 25 & 100 & & & 25 & 7 \\
\hline de Percepção física & & & 10 & 100 & & & 10 & 3 \\
\hline Fasal & & & 97 & 100 & & & 97 & 28 \\
\hline de Tentativa & & & 14 & 100 & & & 14 & 4 \\
\hline Total & 71 & 21 & 150 & 43 & 125 & 36 & 346 & \\
\hline
\end{tabular}

Os predicados encaixadores de experiência psicológica, de percepção física, fasais e de tentativa compartilham marcação de tempo (e, por conseguinte, de modo e aspecto, já que essas referências encontram-se marcadas na predicação matriz) em $100 \%$ dos casos, o que aparece refletido na codificação morfossintática do complemento, que se realiza de forma mais nominal. O critério para considerar dois eventos como cotemporais é a dependência de referência temporal, como se infere da proposta de Givón (1990): eventos simultâneos são eventos cotemporais.

Os estados de coisas dependentes dos predicados encaixadores de volição e de manipulação marcam relações de posterioridade, mesmo sendo esses complementos majoritariamente nominais. Nesses casos, o predicado matriz envolve um elemento de desejo, de intenção: os estados de coisas dependentes são não-realizados (querer ou mandar não significa que o que é desejado ou mandado ocorra) e seu valor modal é irrelevante. Esses traços determinam um alto grau de perda de distinções TAM (que se reflete na forma do complemento, majoritariamente não-finitos para esses predicados). 
Há, então, uma clara dependência conceitual entre os estados de coisas dependentes e predicados matrizes que se reflete na natureza sintaticamente integrada do predicado encaixador e do predicado dependente. Givón (1990) alega que o desejo ou interesse do participante na ocorrência de um estado de coisas desencadeia efeitos de integração semântica. Predicados que envolvem preferência (tais como querer e mandar) determinam um alto grau de integração entre os estados de coisas interconectados, enquanto predicados que não envolvem preferência estão relacionados a um baixo grau de integração semântica.

Predicados encaixadores de enunciação, de atitude proposicional e de conhecimento são comparativamente eventos menos integrados, portanto, mais independentes, por marcarem relações de anterioridade/posterioridade entre os eventos da matriz e da completiva, que, desse modo, são concebidos como dois eventos. Em 95\% (80/84) das ocorrências que envolvem esses tipos de predicados, não há compartilhamento de marcação temporal. Por conseguinte, o complemento é, majoritariamente, codificado como finito.

Há assim, uma correlação relevante entre marcação temporal e codificação de complemento. Um aspecto importante da tipologia que considera a referência TAM é indicar o grau de integração. Quanto maior o grau de independência semântica entre os dois eventos de uma relação complexa, maior a probabilidade de o complemento ser codificado como forma finita. No português, dentro de uma mesma categoria de predicados, ausência ou presença de referência TAM pode corresponder, respectivamente, a eventos finitos e nãofinitos. Marcar as relações temporais de anterioridade, simultaneidade e posterioridade significa expressar um complemento sob a forma finita ou não-finita.

Outro traço que identifica maior ou menor grau de integração morfossintática consiste na correferencialidade entre os participantes da matriz e da completiva. O compartilhamento de participantes desencadeia maior grau de integração morfossintática, enquanto o nãocompartilhamento acarreta maior grau de distanciamento. Observe-se a Tabela 5-4: 
Tabela 5-4: Tipo de predicado encaixador e participantes

\begin{tabular}{lcccccc}
\hline Predicado encaixador & \multicolumn{2}{c}{$\begin{array}{c}\text { Participantes } \\
\text { correferenciais }\end{array}$} & \multicolumn{2}{c}{$\begin{array}{c}\text { Participantes não- } \\
\text { correferenciais }\end{array}$} & \multicolumn{2}{c}{ Total } \\
\cline { 2 - 7 } de Enunciação & $\mathrm{N}$ & $\%$ & $\mathrm{~N}$ & $\%$ & $\mathrm{~N}$ & $\%$ \\
\cline { 2 - 7 } de At. proposicional & 3 & 19 & 13 & 81 & 16 & 5 \\
de Conhecimento & 11 & 39 & 17 & 61 & $28^{82}$ & 8 \\
de Volição & 44 & 52 & 40 & 48 & 84 & 24 \\
de Manipulação & & & 32 & 100 & 32 & 9 \\
de Percepção física & & & 10 & 100 & 10 & 3 \\
de Exp. psicológica & 25 & 100 & & & 25 & 7 \\
Fasal & 97 & 100 & & & 97 & 28 \\
de Tentativa & 14 & 100 & & & 14 & 4 \\
\hline Total & 102 & 42 & 143 & 58 & 342 & \\
\hline
\end{tabular}

Uma vez mais, os dados apontam para uma correlação entre predicados que codificam complementos mais nominais e correferencialidade, e predicados que codificam complementos mais verbais e a falta de correferencialidade.

Predicados de enunciação, de atitude proposicional e de conhecimento dispõem, em sua maioria, de participantes diferentes na matriz e na encaixada. No extremo oposto, predicados de experiência psicológica, fasal e de tentativa dispõem, exclusivamente, de correferencialidade de participantes. Essa distribuição se reflete no tipo de complemento requerido, majoritariamente verbal para participantes diferentes e majoritariamente nominal para participantes correferenciais.

Para os predicados de volição, é a correferencialidade ou não de participantes que determina a codificação do tipo de complemento, mais verbal para participantes diferentes e mais nominal para participantes correferenciais. Por isso, além da determinação semântica do

\footnotetext{
${ }^{82}$ As ocorrências com predicados de conhecimento totalizam 32. Na tabela, aparecem 28 casos a que se aplica a correferencialidade ou não de participantes; 4 casos não computados dizem respeito à nominalização, que, no corpus, tem estatuto genérico.
} 
próprio predicado encaixador, que age como motivação primária, a nominalidade majoritária dos complementos desse tipo de predicado é motivada secundariamente pela correferencialidade de participantes.

Predicados de manipulação e de percepção física, por sua vez, embora exibam, em sua maioria, complementos mais nominais, não apresenta correferencialidade entre participantes, que se mostram irrelavantes para determinar o grau de integração semântica. A explicação para a nominalidade majoritária dos complementos pode, então, estar assentada na perda de distinções TAM: no caso dos predicados de manipulação, como se trata de eventos necessariamente posteriores ao manipulativo, o predicado do complemento aparece codificado numa forma não-marcada em termos de referência TAM; já os predicados de percepção, como os eventos são simultâneos, a referência TAM é codificada como marcada na oração principal.

A Tabela em 5-1, representada pelo Gráfico 5-1 na seção anterior, mostra que há predicados encaixadores que não dispõem de determinados tipos de completivas. No entanto, os dados discutidos na seção 5.3, que tratou de cada predicado encaixador separadamente, permitiram mostrar que o fato de uma forma de completiva não se encaixar em determinado tipo de predicado encaixador não implica o não licenciamento de outras codificações morfossintáticas possíveis.

O que mostram a Tabela 5-1 e o Gráfico 5-1 são as estruturas preferidas registradas nos dados da amostra, que, como já mencionado, não espelham completamente as exigências do predicado encaixador. É relevante, por isso, apresentar agora dados relativos às reais possibilidades de ocorrência das completivas no corpus, que, muitas vezes, são restringidas ou facultadas por aspectos relacionados à integração semântica. Os dados apresentados na Tabela 5-5 dizem respeito à restrição de outra completiva além do tipo originalmente encontrado no corpus. 
Tabela 5-5: Restrição a outros complementos

\begin{tabular}{lccc}
\hline \multicolumn{1}{c}{ Tipo de } & \multicolumn{3}{c}{ Restrição a } \\
predicado encaixador & outro(s) & complemento(s) \\
\hline & N & $\%$ & Total \\
\cline { 2 - 4 } de Atitude proposicional & 16 & 100 & 16 \\
de Enunciação & 28 & 78 & 36 \\
de Conhecimento & 25 & 78 & 32 \\
de Volição & 63 & 75 & 84 \\
de Tentativa & 9 & 64 & 14 \\
de Experiência psicológica & 15 & 60 & 25 \\
Fasal & 53 & 55 & 97 \\
de Percepção física & 5 & 50 & 10 \\
de Manipulação & 1 & 3 & 32 \\
\hline Total & 215 & 62 & 346 \\
\hline
\end{tabular}

Observando-se os dados em sua totalidade, os predicados encaixadores analisados tendem a permitir a expressão morfossintática de somente um tipo de complemento, já que em 62\% (215/346) dos casos não há possibilidade de ocorrência de outra forma de oração completiva além do tipo selecionado; as possibilidades de licenciamento/não-licenciamento de diferentes formas de codificação, no entanto, dependem crucialmente da natureza semântica do predicado encaixador.

Os predicados de atitude proposicional, de enunciação, de conhecimento e de volição são os que mais restringem a ocorrência de outras formas de complementos além da manifestada na amostra. No corpus analisado, os predicados de atitude proposicional, cujas completivas são todas codificadas como finitas no indicativo, restringem a expressão de qualquer outro tipo de complemento. Já os predicados de enunciação observados no corpus, que também codificam exclusivamente complementos finitos no indicativo, restringem outras formas de expressão em $78 \%$ (28/36), ficando a possibilidade de codificar complemento mais nominal restrita a $22 \%$ (8/36). Essa incidência se refere aos casos de compartilhamento de participantes que permitem o encaixador dizer selecionar um complemento não-finito com 
infinitivo, como mostra (5-79a-b). É, então, o compartilhamento de informação referente aos participantes e a TAM que determina a possibilidade de mais de um tipo de ocorrência, isto é, complemento finito e não-finito.

(5-79)a. Doc.: Everton... éh cê me disse que cê sabe fazer TRU:fa BO::lo enTÃO eu queria que cê me explicasse COmo que é assim como que cê aprende::u como que fAz essas coisas? (IBORUNA - AC 047: 177)

b. Doc.: Everton... éh cê me disse saber fazer TRU:fa BO::lo enTÃO eu queria que cê me explicasse COmo que é assim como que cê aprende::u como que fAz essas coisas?

Quando ocorrem com complementos finitos no indicativo, os predicados encaixadores de conhecimento tendem a restringir qualquer outra forma de complemento mais nominal (95\% [19/20]). O único caso que permite outro tipo codificação de complemento além da forma finita no indicativo licencia uma construção não-finita com infinitivo impessoal, porque há compartilhamento de participantes, como mostra (5-80a-b). Quando ocorrem com complementos mais nominais, esses predicados restringem em $13 \%$ (1/8) a possibilidade de ocorrência de outra forma de complemento. As 7 ocorrências que permitem mais de um tipo de codificação, além do tipo de complemento nominal originalmente selecionado, licenciam complementos mais ou menos nominais: 3 ocorrências com infinitivo impessoal licenciam também nominalizações, como em (5-81c-d), e 4 ocorrências com nominalizações licenciam o infinitivo impessoal, como em (5-82a-b), e o indicativo, como em (5-83a-b):

(5-80)a. ...tinha uma boa:: uma área bastante diversificada e eu lembro que eu gostava muito de andar ali... (IBORUNA - AC 084: 140)

b. ...tinha uma boa:: uma área bastante diversificada e eu lembro de gostar muito de andar ali...

(5-81)a. que eles saindo com uma profissão eles num:: pensaria em roubar... pensaria em matar... pensaria em se vingar... (IBORUNA - AC 051: 483)

b. que eles saindo com uma profissão eles num:: pensaria em roubo... pensaria em matar... pensaria em vingança...

(5-82)a. aí eu e/ eu esqueço das outras coisas eu esqueço de bagagem eu esqueço de/ de check in de conferência de bilhete esqueço de desembarque esqueço de embarque esqueço de tudo (IBORUNA - AC 051: 366) 
b. aí eu e/ eu esqueço das outras coisas eu esqueço de bagagem eu esqueço de/ de check in de conferir bilhete esqueço de desembarque esqueço de embarque esqueço de tudo

(5-83)a. aí eu e/ eu esqueço das outras coisas eu esqueço de bagagem eu esqueço de/ de check in de conferência de bilhete esqueço de desembarque esqueço de embarque esqueço de tudo (IBORUNA - AC 051: 366)

b. aí eu e/ eu esqueço das outras coisas eu esqueço de bagagem eu esqueço de/ de check in de conferir bilhete esqueço que (as pessoas) desembarcam esqueço de embarque esqueço de tudo

Dos predicados encaixadores que requerem a expressão de complementos mais nominais (cf. Gráfico 5-1), os predicados de volição são os que mais restringem outra forma de complemento além do tipo originalmente encontrado (75\% [63/84]). A restrição está relacionada à correferencialidade entre participantes ou à ausência dela. Os predicados de volição que restringem a ocorrência de outros tipos de complementos dizem respeito (i) aos que requerem construções não-finitas com infinitivo (das 44 ocorrências, 40 não licenciam outro tipo de complemento): por terem participantes correferenciais não permitem, por exemplo, a ocorrência da completiva codificada como subjuntivo, e (ii) aos que requerem complementos na forma de subjuntivo (das 32 ocorrências, 23 não licenciam outro tipo de complemento), uma vez que, por terem participantes diferentes, não permitem a expressão de formas não-finitas com infinitivo.

Os predicados de volição que licenciam formas alternativas de complemento dão preferência a complementos nominais: dos 21 casos que licenciam a codificação de mais de uma forma, 9 ocorrências com subjuntivo licenciam complementos na forma de nominalização, como em (5-84a-b), 4 ocorrências com nominalização licenciam a codificação do predicado encaixado na forma de subjuntivo, como em (5-85a-b), 4 ocorrências com infinitivo licenciam a expressão de nominalização, como em (5-86a-b), e 4 ocorrências com o indicativo licenciam a codificação do complemento na forma de subjuntivo ou de nominalização, como em (5-87a-c): 
(5-84)a. Inf.: ah! que meu pai contou é meu pai contava que:: quando ele namorava minha mãe era era muito bonita né e tinha bastante moço que gostava dela não queria que ela namorasse (IBORUNA - AC 136:084)

b. Inf.: ah! que meu pai contou é meu pai contava que:: quando ele namorava minha mãe era muito bonita né e tinha bastante moço que gostava dela não queria o namoro dela.

(5-85)a. e eu já tava meio envolvido com E:la e ele pressioNOU pressioNOU basTANte... a mãe NÃO queRIA namoro só que o pai dela falou que era pa ficar aqui na porta de Casa... (IBORUNA - AC 047:114)

b. e eu já tava meio envolvido com E:la e ele pressioNOU pressioNOU basTANte... a mãe NÃO queRIA que a gente namorasse só que o pai dela falou que era pa ficar aqui na porta de Casa...

(5-86)a. existe muito preconceito é a menina que:: por exemplo a menina que:: nu::m num tá afim de namora::r tá afim só de fica::r se ela fica com um monte de meni::no ela fica com fama de gali::nha de menina fá::cil acho que isso deveria acabar porque se a menina num se sente prepara::da pra namora::r se ela num quer namora::r... (IBORUNA - AC 016: 393)

b. existe muito preconceito é a menina que:: por exemplo a menina que:: nu::m num tá afim de namora::r tá afim só de fica::r se ela fica com um monte de meni::no ela fica com fama de gali::nha de menina fá::cil acho que isso deveria acabar porque se a menina num se sente prepara::da pra namora::r se ela num quer um namoro...

(5-87)a. Inf.1.: 28[ai] eu acho o cúmulo (falo) -"gen::te por que que foi fazê(r) isso? largasse lá no planalto... que é duzentos reais... então o padre qué(r) que a gente paga o aluguel... cada um dá um tanto pa pagá(r)... eu dei dez reais (IBORUNA - AI 002:190) $)^{83}$

b. Inf.1.: 28[ai] eu acho o cúmulo (falo) -“gen::te por que que foi fazê(r) isso? largasse lá no planalto... que é duzentos reais... então o padre qué(r) que a gente pague o aluguel... cada um dá um tanto pa pagá(r)... eu dei dez reais

c. Inf.1.: 28[ai] eu acho o cúmulo (falo) -“gen::te por que que foi fazê(r) isso? largasse lá no planalto... que é duzentos reais... então o padre qué(r) o (nosso) pagamento do aluguel... cada um dá um tanto pa pagá(r)... eu dei dez reais

Os predicados de tentativa restringem a ocorrência de outras formas de complementos além do tipo selecionado em 64\% (9/14). Como o Gráfico 5-1 mostra, esses predicados requerem exclusivamente a codificação do complemento sob a forma de verbos não-finitos com infinitivo como núcleo. Nas cinco ocorrências em que esses predicados licenciam outro tipo de complemento, permitem construções nominalizadas, como em (5-88a-b):

\footnotetext{
${ }^{83}$ A alternância da forma no indicativo, em (5-86a), e no subjuntivo, em (5-86b), parece estar relacionada muito mais à variação linguística do que a formas alternativas de gramática.
} 
(5-88)a. Inf.: contaram... que ele tentou assaltar acho que uma:: uma:: acho que uma:: uma loja lá... em Mirassol... uma loja de roupa... então no dia ele tentou assaltar só que aí tinha poli/ Mirassol é pequena... tem polícia né... aí prenderam ele em flagrante ((doc.: ah éh)) é ele tava com porte ilegal de arma... (IBORUNA - AC 039: 086)

b. Inf.: contaram... que ele tentou um assalto acho que em uma:: uma:: acho que em uma:: uma loja lá... em Mirassol... uma loja de roupa...

60\% (15/25) dos predicados de experiência psicológica não licenciam outro tipo de complemento, além da oração completiva originalmente encontrada. No corpus, as possibilidades de mais de um tipo de codificação do complemento dizem respeito a complementos na forma de infinitivo impessoal que licenciam complementos nominalizados, como em (5-89a-b):

(5-89)a. você vai lá você passa um feria::do... você leva a famí::lia você leva os ir/ você leva conheci::do... os cole::ga... a turma gosta de pescar:.... (IBORUNA - AC 132: 205)

b. você vai lá você passa um feria::do... você leva a famí::lia você leva os ir/ você leva conheci::do... os cole::ga... a turma gosta de pescaria::..

55\% (53/97) dos predicados fasais restringem a codificação de outro tipo de complemento além do tipo originalmente encontrado. Nos casos em que se licencia alguma forma alternativa, pode haver a expressão de um complemento nominalizado, quando o complemento original for uma forma no infinitivo (5-90a-b) - isso ocorre em $90 \%$ dos casos que licenciam mais de um tipo -, ou pode haver a expressão de um complemento infinitivo, quando a construção encaixada for uma nominalização, como mostra (5-91a-b):

(5-90)a. : :... ele ele/ esse tio esse avó dele convidou a gente pra tá entrando em estu::dio... a gente já começou a gravar já... a gente tá gravando e:.... (IBORUNA - AC 035: 134)

b. $\quad$ ::.. ele ele/ esse tio esse avó dele convidou a gente pra tá entrando em estu::dio... a gente já começou a gravação já... a gente tá gravando e::...

(5-91)a. : :.... e ele tava no ônibus e quando ele sentou... ele sentou numa coisa da/ na cade::ira... e sentou e até cont/ e continuou a via::gem... vindo de São José do Rio Preto pra Bady Bassit... (IBORUNA - AC 035: 160)

b. $\quad:: . .$. e ele tava no ônibus e quando ele sentou... ele sentou numa coisa da/ na cade::ira... e sentou e até cont/ e continuou a viajar... 
Os predicados de percepção física restringem em $50 \%$ (5/10) a ocorrência de outros tipos de complementos. Além da forma não-finita com infinitivo, esses predicados licenciam também nominalizações, como (5-92a-b).

(5-92)a. Inf.1.: e se ele escuta conversá(r) ele fica na grade uh:: uh:: ele faz né Fernanda? (IBORUNA - AI 007:012)

b. Inf.1.: e se ele escuta uma conversa ele fica na grade uh:: uh:: ele faz né Fernanda?

Os predicados encaixadores que tendem a restringir menos a expressão da completiva são os de manipulação (somente $3 \%$ [1/32] restringem a ocorrência de outros complementos). Por disporem de participantes não-correferenciais, permitem a codificação de completivas na forma de subjuntivo em 69\% (22/29) das ocorrências (22 ocorrências com complementos não-finitos com infinitivo pessoal licenciam também o subjuntivo), como exemplificam (5-93a-b). Além disso, uma ocorrência com indicativo licencia também a expressão do complemento na forma de subjuntivo e de infinitivo pessoal, como em (5-94ac), uma ocorrência de completiva no subjuntivo licencia também a forma de infinitivo impessoal, como em (5-95a-c), e, finalmente, 7 ocorrências codificadas como nominalização licenciam tanto a forma de complemento com infinitivo pessoal quanto a de subjuntivo, como aparece em (5-96a-c).

(5-93)a. Inf.: não a mãe dela entrou na briga fez um acordo... falou assim - "não tá bom ela num te pediu então dessa vez você num empresta ou então você deixa ela pegar e pega um dela" - aí parece que ela deixou depois a irmã usar e pegou uma (da minha amiga)... (IBORUNA - AC 024: 153)

b. Inf.: não a mãe dela entrou na briga fez um acordo... falou assim - "não tá bom ela num te pediu então dessa vez você num empresta ou então você deixa que ela pegue e pega um dela" - aí parece que ela deixou depois a irmã usar e pegou uma (da minha amiga)...

(5-94)a. Inf. 1.: enquanto isso você vai lá no no::... conversá(r) com essa::... m/moça do conselho pra pegá::(r) vê(r) se tem algum documento se ela permite que cê... tira pra xerocá(r) ele (IBORUNA - AI 009:287)

b. Inf. 1.: enquanto isso você vai lá no no:.... conversá(r) com essa::... m/moça do conselho pra pegá::(r) vê(r) se tem algum documento se ela permite que cê... tire pra xerocá(r) 
c. Inf. 1.: enquanto isso você vai lá no no::... conversá(r) com essa::... $\mathrm{m} / \mathrm{moça} \mathrm{do} \mathrm{conselho}$ pra pegá::(r) vê(r) se tem algum documento se ela permite tirar pra xerocá(r) ele

(5-95)a. eu pedi que ele fosse me visitar pra que a gente falasse da bíblia... (IBORUNA - AC 124: 011)

b. eu pedi pra ele ir me visitar pra que a gente falasse da bíblia...

(5-96)a. í:: ela pegou e contratou mais dois estagiários um mês depois quando ela contratou mais dois estagiários aí no aEroporto uma menina pediu demissão... (IBORUNA - AC 051: 129)

í:: ela pegou e contratou mais dois estagiários um mês depois quando ela contratou mais

b. dois estagiários aí no aEroporto uma menina pediu para a demitirem...

í:: ela pegou e contratou mais dois estagiários um mês depois quando ela contratou mais c. dois estagiários aí no aEroporto uma menina pediu que a demitissem...

Com base nos dados, pode-se dizer que predicados que requerem majoritariamente a codificação de complementos verbais no indicativo tendem a restringir mais a ocorrência de formas alternativas do que os predicados encaixadores que requerem completivas mais nominais. ${ }^{84}$ Das 83 ocorrências de complementos finitos no indicativo no corpus (78 das quais dizem respeito aos complementos de predicados de enunciação, de atitude proposicional e de conhecimento), $83 \%$ (69/83) restringem a ocorrência de qualquer complemento alternativo, seja no subjuntivo, seja com construções não-finitas.

No extremo oposto, predicados que, originalmente, requerem completivas sob a forma de subjuntivo, de infinitivo ou de nominalizações (76\% [262/346]), quando licenciam outra forma de complemento além da original (em 47\% [123/262] dos casos), tendem a permitir complementos nominais, excluindo completamente complementos sob a forma de verbos finitos no indicativo. Isso significa que, quando o predicado encaixador licencia mais de uma forma alternativa para a construção dependente, há certa tendência para que (i) se a completiva for uma oração não-finita com infinitivo, ele admita majoritariamente a expressão de complementos sob a forma de nominalização (65\% [61/94] dos casos), ou de verbo no

\footnotetext{
${ }^{84}$ A relação parece óbvia: se o predicado admite um complemento codificado em formas mais nominais, então, na hierarquia verbo/nome, ele também pode admitir complementos codificados em formas mais verbais.
} 
subjuntivo (35\% [33/94] dos casos); (ii) se a completiva for uma nominalização, ele admita a codificação de completivas sob a forma não-finita com infinitivo como núcleo (19\% [3/16] dos casos), sob a forma de subjuntivo (25\% [4/16] dos casos), e sob a forma de indicativo (12\% [2/16] dos casos), ou ainda sob a forma de infinitivo e de subjuntivo juntas (44\% [7/16] dos casos).

É interessante observar que, conforme demonstrado, a maioria das restrições está relacionada ao tipo de predicado encaixador e, adicionalmente, à referência a participantes e a TAM. Não obstante, a codificação de completivas não-finitas sob a forma de nominalização exclui outros tipos de complementos em virtude da natureza genérica da completiva. Observese, a título de ilustração, o exemplo em (5-97):

(5-97)a. Lula detesta aplausos e honrarias. Por isso, pediu para não ser anunciado no sistema de som, entrou depois de iniciado o desfile e recusou o convite do Neguinho.

(Fonte: http://www.notivaga.com.br/mpa_mostra.asp?sid=20092251055395059)

A nominalização em (5-97a) tem estatuto genérico, como qualquer nome de entidade referencial. O predicado encaixador detestar permitiria a codificação de outros tipos de complementação além da nominalização, se fossem respeitadas algumas condições. De um modo geral, esse tipo de predicado licencia também a expressão da oração dependente sob a forma de oração finita e não-finita com infinitivo impessoal. Ocorre que o uso do complemento como oração finita implica a expressão de referência TAM, bem como a de participantes; já o uso da construção não-finita com infinitivo consiste numa situação intermediária, em que se eliminam as circunstâncias temporais, mas não a relação entre eventos etc.

(5-97)b. Lula detesta que a oposição o aplauda.

c. Lula detesta aplaudir a oposição. 
Em (5-97b), a completiva é especificada por distinções também características dos predicados da oração matriz. Já em (5-97c), a oração não-finita continua especificando um agente para a ação de aplaudir e não representa a contraparte verbal direta do que é expresso em (5-97a). Somente a transformação do verbo em nome fornece a condição ideal para a designação genérica.

No caso contido em (5-97a), não é somente o tipo semântico de predicado que determina a forma do complemento, mas a escolha do falante pode também estar relacionada à designação da completiva. A formação de nomes a partir de verbos é produtiva para a denotação do significado verbal como uma entidade ou conceito em si, como em (5-97a), em que o nome aplausos se refere à noção verbal em si, genericamente, sem nenhuma especificação. Subordinar uma predicação é, nos termos da GF (Dik, 1997b), apresentá-la como o núcleo de um termo. Ao empregar um termo como uma nominalização, o falante convida seu interlocutor a atentar para alguma entidade (ou conjunto de entidades), ou seja, para o referente, que não pode ser uma pessoa, animal ou outro objeto tangível. Nos termos de Lyons (1977), deve ser uma entidade de ordem superior: de segunda ou de terceira ordem. Mackenzie (1996) considera que, do ponto de vista semântico, nominalizações são frequentemente empregadas com o propósito de abstração, ou seja, para apresentar noções verbais desprovendo-as de seus acessórios.

As nominalizações constituem exemplos flagrantes de predicados verbais que necessitam submeter-se a ajustes formais próprios de um modelo prototípico de termo, que é o nome de primeira ordem (Dik, 1985; Lyons, 1977). Desse modo, na escala gradativa, essas construções têm características mais nominais, já que se aproximam da estrutura e função de um membro prototípico da classe dos nomes. O estado de coisas constitui-se apenas de um núcleo de predicado que prescinde de termo, porque é tomado genericamente, sem implicar participantes, nem do ponto de vista semântico nem do ponto de vista sintático. 
Há que se considerar ainda que, muitas vezes, para um predicado verbal, não existe, no português, a contraparte nominalizada correspondente, como em (5-98a), o que não permite, então, que o encaixador tome uma nominalização como expressão do complemento, muito embora esse mesmo predicado encaixador, em outra situação, possa licenciar uma nominalização, como em (5-98b):

(5-98)a. Inf.: argola ainda eu não aprendi mas só que... que e::u vou... eu vou fazer um dia... éh eu vou/ eu... eu já fiz... eu já:: quando eu tenho hoRÁrio eu faço corda... mas só que num é no/ no solo e:: também tem... eu gosto muito de fazer casinha e parada de cabeça... (IBORUNA - AC 004: 197)

b. ... quis vim pra cima de mim tal... só que... de certa forma eu num gosto de bri::ga... só que eu sei me defender... corretamente né?... eu empurrava ele dava uns empurrão nele... (IBORUNA - AC 035: 113)

Finalmente, cabe ressaltar que parece haver uma clara razão discursiva para o uso da nominalização nos dados reais retirados da internet. Muitas vezes, esses enunciados representam manchetes de jornais, como ilustram os exemplos em (5-35) e (5-54c), repetidos abaixo. De acordo com Mackenzie (1996), a nominalização permite ao falante dar um nome à entidade de segunda e de terceira ordem, um nome que desfruta de uma versatilidade de uso que complementa a sua versatilidade sintática. Um caso particularmente notável é o uso de nominalizações em títulos, definições etc.

Do ponto de vista pragmático, as nominalizações servem para a condensação de informação, para comprimir o texto, além da coesão textual. A compactividade da nominalização é, então, um traço que motiva o seu uso em elocuções sumárias, como as que aparecem em manchetes.

(5-35) Lula soube da retirada de nódulo em Dilma há 1 semana.

(Fonte: http://www.estadao.com.br/nacional/not_nac360776,0.htm)

(5-54)c. Lula sanciona lei que obriga uso de air bags frontais em carros.

(Fonte: http://www.estadao.com.br/noticias/geral,lula-sanciona-lei-que-obriga-uso-de-air-bagsem-carros,341459,0.htm) 
De um modo geral, pode-se afirmar que a restrição/seleção de orações completivas está relacionada:

(i) ao tipo/subtipo semântico de predicado encaixador, que pode licenciar somente a expressão de uma forma de complemento, como, por exemplo, o predicado encaixador de enunciação falar, que introduz C-complementos finitos no indicativo, ou o predicado encaixador de tentativa procurar, que licencia somente e-complementos não-finitos com infinitivo impessoal;

(ii) ao compartilhamento de informação em relação a (1) participantes, que, quando correferenciais ou não, podem permitir/restringir outros tipos de complementos, como ocorre com o predicado volitivo querer, que, com participantes correferenciais, licencia somente ecomplementos mais nominais e, com participantes diferentes, licencia e-complementos finitos no subjuntivo; e a (2) tempo, modo e aspecto: quando matriz e completiva compartilham referência TAM, o predicado encaixador requer complementos mais nominais.

Em vista das considerações feitas até aqui a respeito da relação entre o tipo de complemento encontrado e a possibilidade de manifestação de outras formas de completivas, a hierarquia proposta em (5-10), repetida abaixo por conveniência, pode ser reorganizada da forma como apresenta (5-99):

\section{(5-10) Predicados encaixadores e escala de sentencialidade/nominalidade do complemento}

de Enunciação > de Atitude proposicional $>$ de Conhecimento $>$ de Volição, de Manipulação, de Percepção física $>$ Fasal $>$ de Experiência psicológica $>$ de Tentativa

em que '>’ significa mais verbal do que

Como a hierarquia em (5-10) considera somente as ocorrências do corpus, predicados de enunciação estão no extremo mais verbal porque, na análise dos dados, requerem a codificação preferencial de complementos finitos no indicativo; no extremo oposto, o 
predicado de tentativa foi considerado mais nominal porque, na análise dos dados, é o que mais requer complementos não-finitos (no infinitivo), excluindo outras formas de codificação. No entanto, em vista das considerações sobre possibilidades alternativas de codificação, apresentadas no Quadro 5-2, repetido por conveniência, a reorganização da hierarquia proposta em (5-99) reflete, de fato, a escala de verbalidade/nominalidade dos complementos licenciados pelos diferentes tipos de predicados encaixadores.

\begin{tabular}{|l|l|l|l|l|l|}
\cline { 2 - 6 } \multicolumn{1}{c|}{} & \multicolumn{1}{c|}{ IND } & \multicolumn{1}{c|}{ SUBJ } & \multicolumn{1}{c|}{ INF. PESS } & INF. IMPESS & \multicolumn{1}{c|}{ NOM } \\
\hline de Enunciação & C-complemento* & C-complemento & & C-complemento & \\
\hline de At. proposicional & p-complemento* & p-complemento & & p-complemento & \\
\hline de Conhecimento & p-complemento* & & & p-complemento & p-complemento \\
\hline de Manipulação & e-complemento & e-complemento & e-complemento* & & e-complemento \\
\hline de Volição & e-complemento & e-complemento* & & e-complemento* & e-complemento \\
\hline $\begin{array}{l}\text { de Experiência } \\
\text { psicológica }\end{array}$ & e-complemento & e-complemento* & & e-complemento* & e-complemento \\
\hline de Percepção física & e-complemento & & e-complemento* & & e-complemento \\
\hline Fasais & & & & e-complemento* & e-complemento \\
\hline de Tentativa & & & & e-complemento* & e-complemento \\
\hline
\end{tabular}

Quadro 5-2: Tipo de predicado encaixador e tipo de complemento

(5-99) Predicados encaixadores e escala de sentencialidade/nominalidade do complemento (reorganizada)

de Enunciação, de Atitude proposicional > de Conhecimento $>$ de Manipulação > de Volição , de Experiência psicológica $>$ de Percepção física $>$ Fasal, de Tentativa

em que '>’ significa mais verbal do que

Na escala proposta em (5-99), predicados de enunciação e de atitude proposicional são os mais verbais por requererem preferencialmente a codificação do complemento sob a forma de indicativo ou, quando muito, sob a forma de predicados não-finitos com infinitivo impessoal. Predicados de conhecimento são menos verbais do que os predicados de atitude proposicional e de enunciação porque, além da forma verbal finita e não-finita com infinitivo impessoal, licenciam nominalizações como complemento. Predicados de manipulação são 
mais verbais que os de volição e de experiência psicológica porque a forma de infinitivo pessoal para a codificação do complemento de predicados é mais verbal do que a de infinitivo impessoal para os complementos de predicados de volição e de experiência psicológica. Predicados de percepção física são mais nominais do que os de manipulação, de volição e de experiência psicológica porque, entre as formas mais nominais, admite somente construções com infinitivo pessoal e nominalização, excluindo a forma de subjuntivo (que é licenciado pelos outros três predicados). Predicados fasais e de tentativa, por fim, são menos verbais que os de percepção física, de experiência psicológica, de volição e de manipulação porque o máximo de verbalidade que a codificação de seu complemento pode tomar é o uso da forma de infinitivo impessoal.

No Nível Representacional, e-complementos constituem uma camada hierarquicamente contida na camada de p-complemento, sendo, portanto, categorias mais baixas. Predicados encaixadores de manipulação, de volição, de experiência psicológica, de percepção física, fasal e de tentativa são hierarquicamente inferiores a predicados de enunciação, de atitude proposicional e de conhecimento porque requerem e-complementos mais nominais. ${ }^{85}$

\footnotetext{
${ }^{85}$ Não há uma relação hierárquica entre C-complemento e p-complemento, visto que as camadas de conteúdo comunicado (C-complementos) e de conteúdo proposicional (p-complementos) não são ordenadas hierarquicamente.
} 
PARTE III:

GENERALIZAÇÕES E IMPLICAÇÕES 


\section{CAPÍTULO 6}

\section{MOTIVAÇÕES FUNCIONAIS DA GRADAÇÃO ENTRE CONSTRUÇÕES ENCAIXADAS NOMINAIS E VERBAIS}

\subsection{Considerações iniciais}

O capítulo anterior mostrou os resultados do tratamento empírico de natureza quantitativa da pesquisa, mediante a descrição e interpretação dos dados. Procurou, assim, identificar fatores, de ordem tanto semântica quanto morfossintática, associados ao comportamento mais ou menos verbal/nominal das completivas.

Cabe, agora, como próximo passo, voltar a discutir as motivações semânticofuncionais para a explicação da seleção/restrição dos tipos de construções capazes de figurarem como complemento de orações hierarquicamente superiores, de modo a comprovar a tese de que:

(i) a semântica do predicado encaixador de completivas é altamente relevante para determinar a categoria morfossintática das predicações dependentes;

(ii) a seleção dos diferentes tipos de codificação depende de motivações funcionais governadas pelo princípio funcional de economia, que representa uma pressão para a simplificação máxima da expressão;

(iii) a relação de gradação entre maior ou menor grau de sentencialidade/nominalidade está vinculada aos níveis e às camada de organização estrutural definidos pela GDF (HENGEVELD; MACKENZIE, 2008).

Essa é a função da seção 6.2, à qual cabe ainda relacionar os resultados obtidos com outros trabalhos, de cunho tipológico, como o de Givón (1980) e de Cristofaro (2003), na tentativa de apontar em que os resultados obtidos nesta pesquisa convergem ou divergem com os princípios formulados nesses trabalhos. 
Cumprida essa tarefa, na seção 6.3, volto a atenção para a tentativa de fornecer uma interpretação adequada do fenômeno aqui estudado a partir da perspectiva da GDF, recorrendo, para tanto, à noção de alinhamento, que pode abrigar satisfatoriamente a interpretação dos diferentes tipos de construções encaixadas em termos de integração semântica.

\subsection{Economia e iconicidade: integração semântica}

Uma primeira afirmação a fazer, em vista da discussão apresentada até aqui, é a de que o estatuto semântico do predicado encaixador e o compartilhamento de informação exercem forte influência sobre o comportamento morfossintático das orações completivas, determinando, em muitos casos, sua forma de expressão.

O capítulo anterior mostrou que o tipo de predicado encaixador seleciona ou restringe determinadas formas de complemento. Entre os predicados envolvidos na relação de complementação pode haver menor ou maior dependência, que é determinada, em primeiro plano, pelo predicado encaixador. O predicado encaixador é, desse modo, o primeiro fator semântico mais relevante na delimitação do tipo formal de construção que pode figurar como complemento. Justamente por isso, é possível pensar numa escala de predicados encaixadores que leve em conta a natureza morfossintática do complemento: num extremo da escala, é possível dispor de predicados que requerem preferencialmente complementos mais verbais, isto é, predicados característicos de ligações mais frouxas com seu complemento; no extremo oposto, há predicados que requerem preferencialmente complementos mais nominais, estabelecendo-se entre oração matriz e completiva uma ligação mais tensa, como aparece na Figura 6-1: 


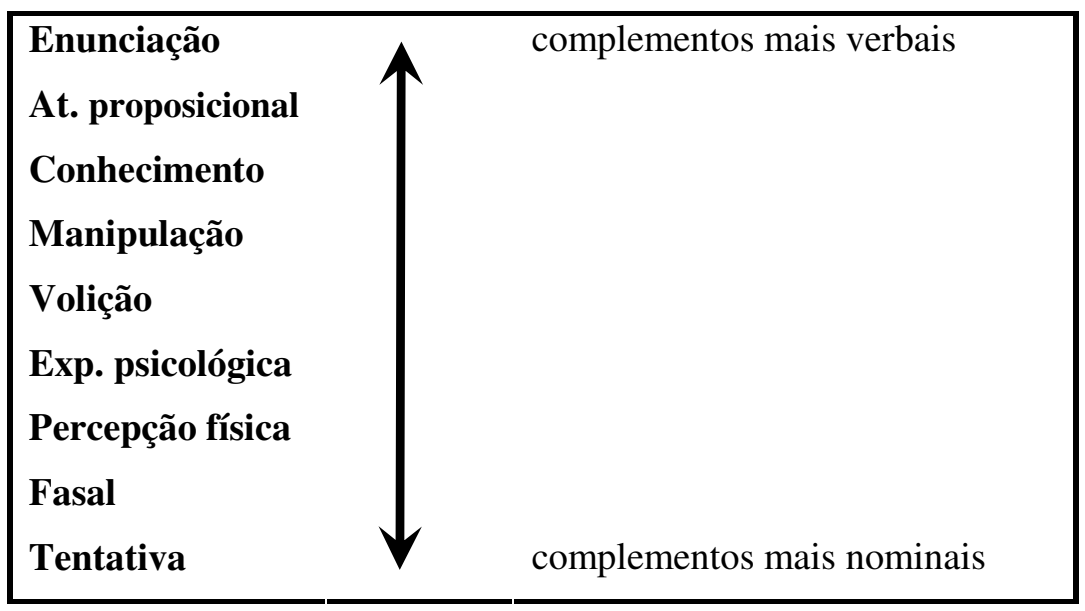

Figura 6-1: Escala de predicados encaixadores

Há uma correlação entre uma hierarquia semântica de manipulação progressiva, que identifica o predicado da matriz, e uma hierarquia morfossintática da predicação dependente, que pode assumir forma de verbo finito a predicado plenamente lexicalizado como nome.

Como mostraram as evidências empíricas, embora possam prevalecer formas mais ou menos verbais como complemento, todos os predicados encaixadores possibilitam ao menos uma forma mais nominal de codificação, quando se trata de predicados complementados principalmente por construções mais verbais, e, alternativamente, uma forma mais verbal, quando se trata de predicados que requerem preferencialmente complementos mais nominais.

O tipo semântico de predicado encaixador pode não ser, no entanto, o único fator na determinação do complemento. Com efeito, outros fatores podem também contribuir para o grau de integração entre as orações nas construções com complementos oracionais finitos e não-finitos. As relações morfossintáticas de complementação dependem de um conjunto de fatores semânticos, relacionados principalmente ao compartilhamento de informação. Como já mencionado, na literatura funcionalista, essas motivações estão ligadas aos princípios de economia e de iconicidade (GIVÓN, 1980; HAIMAN, 1983; CRISTOFARO, 2003).

Conforme a seção 2.3 mostrou, para Cristofaro (2003), a economia sintagmática explica a correlação entre a predeterminação de traços semânticos no estado de coisas encaixado e a codificação morfossintática que se traduz na não especificação de informação 
correspondente, processo denominado Princípio de Recuperabilidade de Informação. A economia sintagmática está fortemente correlacionada com a predeterminação de informação semântica em estados de coisas conectados e a não manifestação de informação pragmaticamente compartilhada pelos participantes da interação. Se, por exemplo, a referência TAM de uma predicação dependente é predeterminada pelos traços semânticos da predicação principal, não é necessária especificação no verbo da predicação dependente.

Os dados apresentados no capítulo anterior mostram que tanto o predicado da matriz quanto o da oração encaixada, numa relação de subordinação, são marcados por diferentes graus de interconexão cujos efeitos são o compartilhamento de participantes e de marcas de TAM, fato que é conhecido na pesquisa tipológica como integração semântica (GIVÓN, 1980, 1990; NOONAN, 1985, CRISTOFARO, 2003). Com efeito, é possível propor a hierarquia em (6-1) para a codificação morfossintática da completiva, que seria determinada, primeiramente, pela natureza semântica do predicado encaixador, em segundo lugar, pelo compartilhamento de participantes e, por último, pelo compartilhamento de referência TAM:

Predicado encaixador $>$ Participantes $>$ TAM

Em termos de predeterminação da codificação morfossintática motivada pelo predicado encaixador, pelo compartilhamento de argumentos e e por referência TA(M), há casos em que a seleção do modo subjuntivo representa um alinhamento morfossintático. É o que ocorre com os predicados de experiência psicológica em que não há compartilhamento de argumentos e a codificação da completiva sob a forma de subjuntivo indica apenas que é uma oração dependente: parece que TAM seria dispensável porque o que o subjuntivo indica é que o tempo e aspecto do predicado encaixador são os mesmos do da encaixada; já o modo, por definição, não, na medida em que se tem o indicativo para o predicado matriz e o subjuntivo 
para o predicado encaixado. Nesses casos, o subjuntivo é morfossintaticamente motivado, enquanto a referência a TA e a argumentos é semanticamente motivada.

De modo geral, as evidências discutidas comprovam a correlação existente entre o grau de integração de um complemento oracional a uma oração matriz e seu comportamento morfossintático, definido como um conteúdo comunicado, um conteúdo proposicional e um estado de coisas. Considerando tanto a influência do predicado encaixador quanto o compartilhamento de informações referentes a participantes e TAM, foi possível chegar à hierarquia de complementação apresentada em (5-99), repetida abaixo por conveniência:

(5-99) Predicados encaixadores e escala de sentencialidade/nominalidade do complemento (reorganizada)

de Enunciação, de Atitude proposicional $>$ de Conhecimento $>$ de Manipulação $>$ de Volição , de Experiência psicológica $>$ de Percepção física $>$ Fasal, de Tentativa

em que '>’ significa mais verbal do que

Os predicados encaixadores que se identificam semanticamente com os tipos de enunciação, de atitude proposicional e de conhecimento determinam o tipo de complemento requerido, morfossintaticamente mais verbal, mas o compartilhamento de participantes e a referência TAM também são relevantes para determinar o tipo de complemento. Os predicados encaixadores que definem semanticamente os tipos de manipulação e de percepção física são determinantes para selecionar a forma da completiva, morfossintaticamente mais nominal, já que a ausência de correferencialidade entre participantes bem como a perda de distinções TAM não tem relevância alguma. A relação que se estabelece entre o predicado de volição e a forma morfossintática do complemento depende tanto do predicado encaixador quando do compartilhamento ou não de participantes, que é o que, de fato, restringe determinada codificação da completiva. Essa correlação é verdadeira para os predicados semanticamente definidos como de experiência psicológica. Os predicados fasal e de tentativa têm relevância integral para a determinação da forma da 
completiva, já que esses predicados requerem participantes correferenciais com o complemento.

O enfoque funcionalista privilegia o estudo das relações sintático-semânticas entre o predicado encaixador e seu complemento sob a perspectiva tipológica, que prevê o estudo de padrões organizacionais (semelhantes ou não) entre variados sistemas linguísticos.

Givón (1980, 1995) destaca uma relação de isomorfismo entre as dimensões semântica e (morfos)sintática da complementação. A dimensão semântica envolve a integração cognitiva de eventos, ao passo que a dimensão (morfos)sintática implica o grau maior ou menor de integração formal de uma oração na outra. Parte-se do princípio de que quanto maior a ligação semântica entre dois eventos tanto maior a integração sintática de suas orações em uma relação complexa. Em outras palavras, a complexidade sintática é uma conseqüência da complexidade cognitivo-semântica. Ao tratar das relações de complementação, Cristofaro (2003), por seu lado, focaliza os seus traços semânticos com base em três aspectos: (a) nível da estrutura oracional; (b) predeterminação; (c) integração semântica.

Com base em Givón (1980) e Cristofaro (2003), o Capítulo 2 mostrou que a natureza semântica do predicado encaixador pode ser vista como um fator indicativo do grau de integração da oração subordinada à matriz. Os diferentes graus de integração entre orações são explicados pelo princípio de iconicidade diagramática (HAIMAN, 1983), segundo o qual a integração sintática entre as orações reflete iconicamente a integração semântica entre os eventos codificados. Em outras palavras, se os dois eventos na oração principal e na oração completiva estiverem integrados em um único evento complexo, as orações constituirão uma única oração complexa.

Os complementos não-finitos com infinitivo e nominalização podem atuar como exemplo de um dos extremos de motivação funcional por iconicidade (HAIMAN, 1983; GIVÓN, 1980), segundo o qual a integração semântica entre os eventos se reflete na 
integração morfossintática entre as orações. Desse modo, as formas mais nominais dependentes constituem o tipo de construção encaixada com o maior grau de integração semântica, em oposição às formas verbais mais e menos dependentes. No outro extremo, a relação de iconicidade se explica pelo grau maior de independência da oração completiva, sinalizado pela codificação mais verbal de seu predicado.

Em termos de integração semântica, Cristofaro (2003) considera que diferentes relações de complementação têm diferentes implicações sobre a referência TAM e participantes do estado de coisas ligado. Segundo Givón (1993, p.7), “quanto maior a contiguidade temporal entre dois eventos tanto maior a probabilidade de serem representados cognitivamente como um evento único do que como dois eventos independentes". ${ }^{86}$ Essa correlação significa que, se as orações compartilham o mesmo tempo, os dois eventos codificados tendem a formar, cognitivamente, um evento único e serem codificados, portanto, com um grau maior de dependência morfossintática.

Os estados de coisas principal e dependente numa relação de subordinação podem ter vários graus de interconexão, em termos de compartilhamento de participantes e de marcação TAM. Com base nesse parâmetro, vale relembrar que Cristofaro (2003) propõe uma relação entre predicados encaixadores e integração semântica, repetida abaixo por conveniência:

\begin{tabular}{|l|l|}
\hline a Hierarquia da integração semântica & Sem integração semântica \\
\hline $\begin{array}{l}\text { Fasais > Modais > Manipulativos ('fazer') > } \\
\text { Manipulativos ('ordenar'), Volitivos e de Conhecimento, de Atitude proposicional e } \\
\text { Percepção }\end{array}$ & de Enunciação \\
$\begin{array}{l}\text { em que '>' significa 'envolve maior grau de } \\
\text { integração semântica do que' }\end{array}$ \\
\hline
\end{tabular}

Quadro 2-2: Integração semântica (adaptado de Cristofaro, 2003, p.122)

\footnotetext{
${ }^{86}$ Cf. original: The more temporally contiguous two events are, the more likely they are to be represented cognitively as a single event, rather than as two independent events.
} 
Considerando que, em maior ou menor grau, todos os tipos de predicados encaixadores analisados envolvem integração semântica, as evidências discutidas aqui contradizem parcialmente a alegação de Cristofaro (2003) de que predicados de enunciação, de atitude proposicional e de conhecimento não envolvem nenhum grau de integração semântica. Com efeito, a possibilidade que esses predicados apresentam de tomarem como complemento predicados não-finitos permite postular que eles também envolvem relação de integração semântica com a oração dependente, ainda que tendam a admitir a codificação de verbo finito para seus complementos. Para a complementação do português, é possível postular a seguinte hierarquia de integração semântica:

\begin{tabular}{|c|}
\hline \multicolumn{1}{|c|}{ Hierarquia da integração semântica } \\
\hline Tentativa, Fasais > Percepção física > Volição, Experiência psicológica > \\
Manipulação > Conhecimento > Atitude proposicional, Enunciação \\
em que '>' significa 'envolve maior grau de integração semântica do que' \\
\hline
\end{tabular}

Quadro 6-1: Hierarquia de integração semântica

Uma justificativa possível para a divergência entre os resultados apresentados neste trabalho e a tipologia de Cristofaro (2003) pode estar no fato de ser o português uma língua indo-européia, românica, um tipo de língua que não aparece na amostra de Cristofaro, que compreende línguas européias não pertencentes ao tronco indo-europeu.

Com a hierarquia de ligação e a tipologia de complementos, Givón (1980) estabelece a relação entre a natureza semântica do predicado encaixador e a estrutura formal de seus complementos. Segundo o autor, as categorias semânticas são representadas iconicamente na estrutura da oração completiva.

Na escala gradativa de integração semântica que Givón (1980) constrói, quanto maior a tendência para o polo esquerdo das relações entre predicado encaixador e predicado, maior o grau de independência da completiva; a recíproca é também verdadeira: quanto maior a 
tendência para o polo direito das relações de complementação, maior o grau de lexicalização da completiva, como mostra o Quadro 2-1, repetido aqui por conveniência.

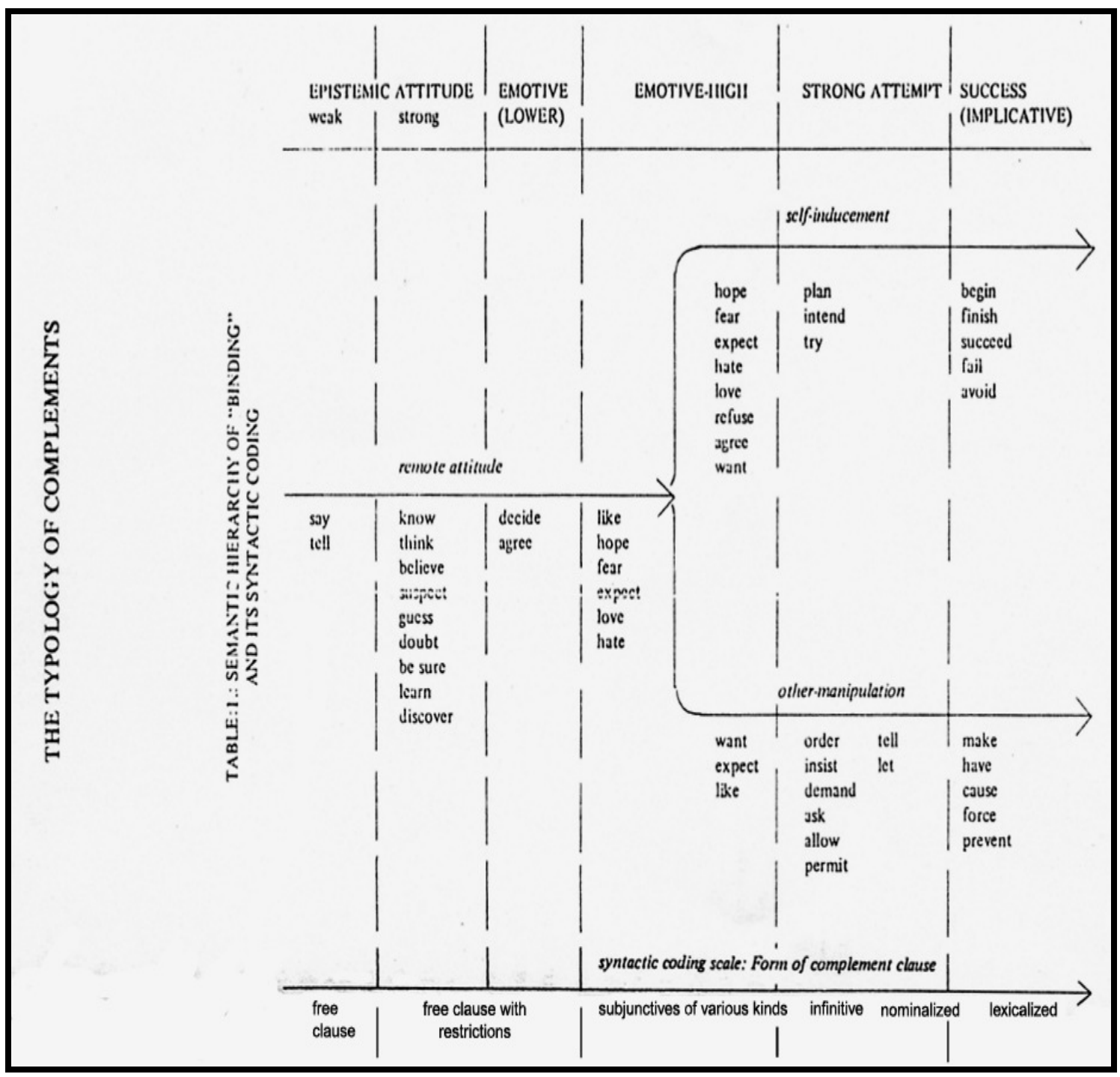

Quadro 2-1: Hierarquia da ligação (Givón, 1980, p.369)

Nos dados examinados, a tendência de distribuição dos predicados encaixadores está parcialmente em conformidade com as predições de Givón (1980). Na medida em que avançam para a zona mais à direita da escala, as construções vão se tornando mais dependentes sintática e semanticamente, para se tornarem completamente integradas, a ponto de designarem um mesmo evento. Predicados de atitude epistêmica fraca (predicados de enunciação) tomam complementos finitos, tanto quanto os predicados de atitude epistêmica forte (predicados de atitude proposicional e de conhecimento), já predicados que envolvem 
atitude emocional forte e fraca (predicados de experiência psicológica e de volição), forte tentativa (predicados de manipulação) e implicabilidade (predicados de tentativa e fasais) tomam construções não-finitas com infinitivo e nominalizações como núcleo.

As predições se cumprem parcialmente porque as relações que se estabelecem entre os tipos de predicados e tipos de complementos, em alguns casos, não são absolutamente fechadas, mas preferenciais, de modo não ser possível sustentar que um determinado tipo semântico de predicado encaixador requeira uma única forma de complemento. As especificidades de cada predicado encaixador no que diz respeito às alternativas possíveis de complementação mostram diferenças entre o tratamento fornecido por Givón (1980) e os resultados apresentados neste trabalho, conforme mostra o Quadro 6-2.

\begin{tabular}{|c|c|c|c|}
\hline $\begin{array}{c}\text { Tipo de predicado } \\
\text { analisado }\end{array}$ & $\begin{array}{c}\text { Tipo de complemento } \\
\text { requerido }\end{array}$ & $\begin{array}{c}\text { Estrutura semântica } \\
\text { do predicado (Givón, } \\
1980 \text { ) }\end{array}$ & $\begin{array}{l}\text { Configuração sintática } \\
\text { (Givón, 1980) }\end{array}$ \\
\hline Enunciação & $\begin{array}{l}\text { Indicativo; Subjuntivo; } \\
\text { Infinitivo impessoal }\end{array}$ & $\begin{array}{l}\text { Atitude Epistêmica } \\
\text { fraca }\end{array}$ & Oração livre \\
\hline Atitude proposicional & $\begin{array}{l}\text { Indicativo; Subjuntivo; } \\
\text { Infinitivo impessoal }\end{array}$ & $\begin{array}{l}\text { Atitude Epistêmica } \\
\text { forte }\end{array}$ & Oração livre com restrições \\
\hline Conhecimento & $\begin{array}{l}\text { Indicativo; Infinitivo } \\
\text { impessoal; } \\
\text { Nominalização }\end{array}$ & $\begin{array}{l}\text { Atitude Epistêmica } \\
\text { forte }\end{array}$ & Oração livre com restrições \\
\hline Manipulação & $\begin{array}{l}\text { Indicativo; Subjuntivo; } \\
\text { Infinitivo pessoal; } \\
\text { Nominalização }\end{array}$ & Forte Tentativa & $\begin{array}{l}\text { Infinitivo, construções } \\
\text { nominalizadas, } \\
\text { lexicalizadas }\end{array}$ \\
\hline Volição & $\begin{array}{l}\text { Indicativo; Subjuntivo ; } \\
\text { Infinitivo impessoal ; } \\
\text { Nominalização }\end{array}$ & Atitude Emotiva forte & Subjuntivo de vários tipos \\
\hline $\begin{array}{l}\text { Experiência } \\
\text { psicológica }\end{array}$ & $\begin{array}{l}\text { Indicativo; Subjuntivo; } \\
\text { Infinitivo impessoal; } \\
\text { Nominalização }\end{array}$ & Atitude Emotiva forte & Subjuntivo de vários tipos \\
\hline Percepção física & $\begin{array}{l}\text { Indicativo; Infinitivo } \\
\text { pessoal; Nominalização }\end{array}$ & $\begin{array}{l}\text { Desconsiderado pelo } \\
\text { autor }\end{array}$ & Desconsiderado pelo autor \\
\hline Fasal & $\begin{array}{l}\text { Infinitivo impessoal; } \\
\text { Nominalização }\end{array}$ & Implicativos & $\begin{array}{l}\text { Construções nominalizadas, } \\
\text { lexicalizadas }\end{array}$ \\
\hline Tentativa & $\begin{array}{l}\text { Infinitivo impessoal; } \\
\text { Nominalização }\end{array}$ & Implicativos & $\begin{array}{l}\text { Construções nominalizadas, } \\
\text { lexicalizadas }\end{array}$ \\
\hline
\end{tabular}

Quadro 6-2: Resultados obtidos em comparação às predições de Givón (1980) 
Novamente aqui, o que está em foco é que, em menor ou maior grau, todos os tipos de predicados encaixadores envolvem integração semântica, e isso se reflete na codificação morfossintática do complemento, que pode ser mais ou menos verbal/nominal. Não é possível identificar o complemento não-finito com infinitivo de um predicado de enunciação com a noção de "forma livre".

Já em relação aos predicados fasais e de tentativa (implicativos, na definição de Givón (1980)), é completamente rígida a relação entre o predicado encaixador e seu complemento. Tal como aponta Givón (1980), são predicados que requerem completivas nominais, infinitivas ou nominalizadas.

Predicados de enunciação, por seu lado, envolvem baixo grau de integração semântica, visto que, como predicados de atitude epistêmica fraca, tomam complementos oracionais independentes. Não se pode menosprezar, entretanto, a viabilidade de construções alternativas à codificação não-finita do predicado da completiva. Com efeito, predicados de enunciação podem, em algumas situações, licenciar a forma infinitiva para o complemento, fenômeno que sinaliza integração. Muitas vezes, a restrição/seleção está relacionada à subcategorização semântica do predicado.

Predicados de atitude epistêmica forte ocorrem com complementos menos integrados à oração matriz. Segundo Cristofaro (2003), predicados de atitude proposicional e de conhecimento, assim como os predicados encaixadores de enunciação, não dispõem de alto grau de integração semântica. Cabe salientar, entretanto, que esses predicados também licenciam, além da completiva finita, oração não-finita com infinitivo e com nominalização.

O inverso também é verdadeiro: predicados que tomam como complementos construções mais integradas também licenciam a expressão de uma forma mais independente. Essa possibilidade de complementação alternativa aparece com predicados de atitude emotiva forte, bem como com predicados de forte tentativa. 
A correlação entre o tipo semântico de encaixador e a forma de complemento requerida pode também ser vista a partir do tipo de entidade que a completiva representa. Hengeveld (1998) faz referência ao fato de que, no caso de complementação, a natureza da representação subjacente do complemento oracional depende semanticamente do predicado encaixador. Postulo, adicionalmente, que o tipo de unidade semântico-funcional de uma oração completiva reflete o grau de integração gramatical (maior ou menor) que ela mantém com a oração matriz.

Observando o tipo de entidade designada a partir da possibilidade de ocorrências dos diferentes tipos de complementos, pode-se chegar ao seguinte quadro:

\begin{tabular}{|ccc|}
\hline C-complemento & p-complemento & e-complemento \\
\hline indicativo* & indicativo* & indicativo \\
subjuntivo & subjuntivo & subjuntivo* \\
& & infinitivo pessoal* \\
infinitivo impessoal & infinitivo impessoal & infinitivo impessoal* \\
& nominalização & nominalização \\
\hline Quadro 6-3: Tipo de entidade e forma assumida & $*$ Forma preferencial & \\
\end{tabular}

Uma primeira observação a fazer é que, de fato, em termos de complementos preferencial ou exclusivamente requeridos, a relação de gradação entre maior ou menor grau de sentencialidade/nominalidade está vinculada aos níveis e às camada de organização estrutural definidos pela GDF (HENGEVELD; MACKENZIE, 2008) nos seguintes termos: quanto mais alta a camada mais externa de uma oração complemento, mais provavelmente ela será expressa por uma forma verbal independente.

\footnotetext{
${ }^{87} \mathrm{O}$ subjuntivo e o infinitivo pessoal e impessoal aparecem juntamente como formas preferenciais para ecomplementos porque, para determinar o tipo preferencial, é necessário observar o tipo semântico de predicado encaixador e, consequentemente, se o compartilhamento de participantes seleciona/restringe a codificação do complemento (cf. nota 80, p. 213). Os predicados de percepção direta, por exemplo, tomam como forma preferida e-complementos com infinitivo pessoal; já os predicados de volição tomam como única forma possível tanto e-complementos com infinitivo impessoal quanto e-complementos no subjuntivo, dependendo da correferencialidade dos participantes.
} 
Não obstante, em conformidade com o Quadro 6-3, não é possível alegar que as diferentes entidades designadas pelo complemento refletem fielmente essa relação entre camada de representação e verbalidade/nominalidade da completiva. C-complementos e pcomplementos ocorrem preferencialmente no indicativo, mas, observadas algumas particularidades, como compartilhamento de participantes, podem ocorrer como construções mais nominais. Do mesmo modo, e-complementos podem ser considerados como mais nominais em relação a C-complementos e p-complementos, já que pertencem à camada mais interna; deveriam, desse modo, ocorrer com complementos mais nominais, mas, embora formas mais nominais sejam requeridas, e-complementos também licenciam formas mais verbais.

É interessante observar que a ocorrência de complementos mais nominas requer, no quadro de complementos possíveis, construções mais verbais. Assim, um predicado que licencia p-complemento ou um e-complemento nominalizado deve, necessariamente, licenciar um p-complemento ou um e-complemento mais verbal (infinitivo, subjuntivo, indicativo). Similarmente, um predicado que licencia um C-complemento, ou um p-complemento ou ainda um e-complemento no infinitivo deve, necessariamente, licenciar construções mais verbais que o infinitivo (subjuntivo, indicativo).

$\mathrm{Na}$ seção introdutória, à vista desses resultados, propus examinar qual seria a classificação tipológica do português em relação às construções encaixadas. É uma tarefa complexa determinar o tipo de língua com base em um estudo não comparativo como este.

De qualquer modo, vale lembrar que Koptjevskaja-Tamm (1993) alega ser possível classificar as línguas em dois tipos bem definidos: línguas de complemento equivalente (complement-balancing languages) e línguas de complemento rebaixado (complementderanking languages). 
Conforme a análise demonstrou, o português não ocupa nenhum desses polos opositivos, já que os complementos possíveis abrigam um continuum. Lembrando a tipologia de construções encaixadas proposta por Dik (1997b) e adaptada por Camacho (2009), apresentada na Figura 2-2 (p. 88), deduzo que ela é insuficiente para abrigar a escala de completivas de o português dispõe, já que aquela tipologia inclui apenas dois extremos, representados pelas construções encaixadas finitas e pelas não-finitas. Vimos, todavia, que, no polo das finitas, o português dispõe de encaixadas no indicativo e no subjuntivo, e apenas as primeiras são equivalentes sintaticamente à predicação encaixadora. Nesse caso específico, assumo a posição de Cristofaro (2003), que, divergindo de Hengeveld (1998), para o qual tanto as construções no indicativo quanto as no subjuntivo são equivalente, postula que somente as primeiras podem ser assim consideradas. ${ }^{88}$ Já no polo das não-finitas, o português dispõe de construções encaixadas infinitivas pessoais e impessoais e de construções encaixadas nominalizadas. ${ }^{89}$

\subsection{Alinhamento representacional e integração semântica}

A discussão desenvolvida até aqui se dirige à sustentação da hipótese de que a complementação requer uma relação entre o tipo de predicado encaixador e o tipo morfossintático requerido, bem como a atuação de outros critérios semânticos como a correferencialidade entre participantes e a referência a categorias de tempo, modo e aspecto. A descrição e interpretação apresentadas no capítulo e na seção anteriores mostram que a expressão linguística não é morfossintaticamente arbitrária e, portanto, autossuficiente, mas é o resultado da atuação de princípios semânticos. Camadas do nível Representacional exercem papel relevante na codificação das formas de complementação.

\footnotetext{
${ }^{88}$ Conforme vimos, há construções de experiência psicológica que requerem o subjuntivo não por razões de ordem semântica, mas apenas para assinalar a dependência sintática da encaixada.

${ }^{89}$ Lembro que existe a possibilidade também de contarmos com construções participiais reduzidas de gerúndio, que não foram consideradas neste trabalho por definirem apenas aspecto progressivo.
} 
A GDF sistematiza nos níveis e camadas de representação que postula a intuição givoniana (1980, 1993) de integração semântica, acomodando formalmente as tendências observadas por Givón e outros linguistas. O Nível Representacional e o Nível Interpessoal permitem distinguir diferentes tipos de complementos, determinados, sobretudo, pela categoria semântica do predicado encaixador (cf. HENGEVELD; MACKENZIE, 2008). Hengeveld (1989) sugere que construções subordinadas sejam classificadas de acordo com a camada mais alta que as contenha. Diferentes predicados encaixadores requerem diferentes tipos de complemento: os complementos podem, então, ser caracterizados segundo o tipo de entidade que designam. Essa dependência permite fazer fortes predições sobre a possibilidade de expressar operadores de tempo, modo e aspecto: quanto mais alta a camada mais externa de uma oração complemento, mais provavelmente ela será expressa por uma forma verbal independente. Esse fato está plenamente de acordo com a correlação entre tipos morfossintáticos de subordinação e grau de integração semântica entre predicação encaixada e predicação matriz.

Um tratamento importante para as relações de complementação diz respeito à noção de alinhamento apresentada pela GDF. Como mencionado no Capítulo 3, o alinhamento se refere ao modo como unidades semânticas e pragmáticas, não relacionadas hierarquicamente, projetam-se nas unidades morfossintáticas.

O alinhamento relevante para as relações de complementação do português brasileiro é o alinhamento representacional. Esse tipo de alinhamento diz respeito ao modo como a organização morfossintática reflete a organização das unidades do Nível Representacional, seja em termos de suas funções semânticas (Actor, Undergoer etc), seja em termos de sua designação, que exibem alinhamento hierárquico, quando dependem de hierarquias como a de animacidade e a de pessoalidade. 
Postulo aqui a extensão da noção de alinhamento representacional à designação de eventos, possibilidade que permite acomodar o processo de integração semântica no tratamento das relações de complementação. A noção de alinhamento mostra que há alguns princípios que se resolvem apenas no Nível Morfossintático: são de natureza formal, mas outros mostram relações de economia e iconicidade.

O alinhamento representacional pode ser entendido a partir do princípio de iconicidade de Haiman (1983), vista por Givón (1980) como mecanismo de integração semântica: tendo em vista a semântica do predicado encaixador, quanto mais externa a camada do predicado encaixado mais sentencial ou menos nominal é a oração completiva. Essa relação tem a ver com as camadas definidas pela GDF. A natureza semântica do predicado encaixador define o tipo de completiva, ora no Nível Representacional, ora no Nível Interpessoal. Quanto mais alta a camada de representação, mais equivalente é a relação do verbo da subordinada com o verbo da matriz. Se o complemento designa um estado de coisas, é maior o grau de dependência entre o predicado encaixador e a completiva e, portanto, tanto menor o grau de sentencialidade da completiva (LEHMANN, 1988).

O modo como o grau de integração semântica se reflete na codificação morfossintática está no uso de formas não-finitas, com a não-especificação de morfema modo-temporal e de argumentos. A economia tem a ver com o compartilhamento de marcação TAM e de correferencialidade de argumentos, geralmente o sujeito da matriz da encaixada, o que é também uma propriedade semântica. O compartilhamento de argumentos e de referência TAM desencadeia uma economia semanticamente motivada, na medida em que esses traços não precisam ser especificados no verbo dependente.

A literatura se refere a esse fenômeno de correferencialidade que atravessa a fronteira entre a oração principal e a oração subordinada como logoforicidade, reservando o termo 
reflexividade para referir-se ao mesmo fenômeno semântico ocorrendo no interior dos limites de uma oração.

Hengeveld e Mackenzie (2008) mencionam uma situação típica de uso de logofóricos em oposição ao uso de reflexivos no babungo, um tipo de correferência necessariamente restrita ao controle do sujeito. Para codificar a noção semântica de reflexividade, a gramática dessa língua dispõe de uma estratégia perifrástica envolvendo o nome 'ywáa', 'corpo', que serve justamente para indicar correferência no interior da oração, como se vê em (6-2a). Nas situações em que a correferencialidade ultrapassa os limites formais da oração principal para indicar compartilhamento do participante sujeito com a oração dependente, a gramática do babungo lança mão de pronomes logofóricos, como se observa em (6-2b).

\begin{tabular}{|c|c|c|c|c|}
\hline -2)a. & $\begin{array}{l}\text { Mò sò } \\
\text { I } \quad \text { wash.PFV }\end{array}$ & $\begin{array}{l}\text { ywáa } \\
\text { body }\end{array}$ & $\begin{array}{l}\text { ywāa } \\
\text { my }\end{array}$ & \\
\hline & ' $\mathrm{I}_{\mathrm{i}}$ washed myse & & & \\
\hline b. & ywว̀ gì & lāa & yì & táa \\
\hline & say.PFV & CONJ & 3.LOG & FUT \\
\hline
\end{tabular}

'He $\mathrm{i}_{\mathrm{i}}$ said that he $\mathrm{i}_{\mathrm{i}}$ would come.' $\quad$ (cf. HENGEVELD; MACKENZIE, 2008, p. 375)

O sistema morfossintático do português não dispõe da diferença que o babungo estabelece entre reflexivos para representar o fenômeno semântico da correferencialidade ocorrendo no interior da oração simples e pronomes logofóricos para representar o fenômeno semântico da correferencialidade através da fronteira entre a oração principal e a dependente. Mesmo assim, é possível postular que o sistema morfossintático do português contempla essa diferença semântica, codificando o primeiro fenômeno como pronome reflexivo e o segundo como zero anafórico.

A GDF identifica os casos de anáfora zero com a categoria de núcleo ausente (Absent Head) que se opõe à categoria de núcleo vazio (Empty Head). Observem-se (6-3a) e (6-3b): 
(6-3)a. O pintor lixou a parede e $\varnothing$ consertou a porta.

b. Maria quer namorar um cara bonito, mas eu prefiro um honesto.

Em (6-3a), a elipse representada por $\emptyset$ indica a ocorrência de uma relação anafórica entre a descrição precedente $o$ pintor, representada pela variável coindexada para indivíduo $\left(\mathrm{x}_{\mathrm{i}}\right)$. Como em (6-3a) o núcleo da segunda oração está simplesmente ausente, é essa variável em si mesma que explica o processo de designação. Em (6-3b), por outro lado, ausência de menção estabelece uma relação anafórica com a propriedade homem antes mencionada, que é representada pela variável coindexada para propriedades $\left(\mathrm{f}_{\mathrm{i}}\right)$, conforme a representação em (63c):

(6-3)c. $\quad\left(\mathrm{x}_{\mathrm{i}}:\left[\mathrm{f}_{\mathrm{i}}: \operatorname{homem}\left(\mathrm{f}_{\mathrm{i}}\right)\right)\left(\mathrm{x}_{\mathrm{i}}\right)_{\Phi}\right]:\left[\left(\mathrm{f}_{\mathrm{j}}\right.\right.$ : honesto $\left.\left.\left.\left(\mathrm{f}_{\mathrm{j}}\right)\right)\left(\mathrm{x}_{\mathrm{i}}\right)_{\Phi}\right]\right)$.

Nessa segunda situação, há uma posição de núcleo dentro da camada-x, mas ela é preenchida com a variável propriedade, não com um material lexical, como ocorre nas situações de ausência de núcleo como (6-3a). Trata-se em (6-3b) de um caso de núcleo vazio. Portanto, o modo como o sistema morfossintático do português interpreta a situação de logoforicidade do babungo é mediante o uso de zeros anafóricos, que a GDF representa como casos de Núcleos Ausentes.

A correferencialidade entre um argumento da predicação matriz e um argumento da predicação encaixada, que se projeta sobre a categoria de núcleo ausente no Nível Morfossintático, constitui, portanto, mais uma situação típica de alinhamento representacional.

Os princípios de projeção, chamados de alinhamento, são motivados por princípios universais de economia e iconicidade. No entanto, a organização morfossintática que os reflete é sempre particular e depende de cada sistema linguístico. A codificação morfossintática da completiva é motivada no Nível Representacional pelo tipo semântico do 
predicado encaixador. As diferentes línguas podem codificar diferentemente os tipos de encaixamento. A natureza semântica da relação é a mesma, mas não a codificação morfossintática final da construção, que pode variar conforme a natureza própria de cada sistema linguístico. Pode-se alegar, portanto, que o grau de universalidade que a teoria linguística pode postular está no domínio funcional em que as motivações semânticas aparecem, enquanto o grau de particularidade se revela na natureza morfossintática do encaixamento.

O português, especificamente, exibe um alinhamento representacional entre unidades não hierárquicas do Nível Morfossintático em que as camadas do Nível Representacional exerce papel na escolha das formas de complementação: predicados que introduzem conteúdos comunicados e conteúdos proposicionais tendem a requerer complementos finitos (C-complementos e p-complementos) no indicativo, preferencialmente, enquanto predicados que designam estados de coisas tendem a requerer complementos mais nominais (ecomplementos), construções não-finitas com infinitivo e nominalização.

É possível sustentar que a nominalização, especificamente, é o resultado mais evidente do princípio de motivação funcional por iconicidade (GIVÓN, 1980), segundo a qual a integração semântica entre os eventos se reflete na integração morfossintática entre as orações. Desse modo, juntamente com outras formas dependentes com verbos não-finitos, constitui o tipo de construção encaixada com o maior grau de integração semântica. A nominalização implica, assim, o grau máximo de integração, na medida em que envolve menor complexidade categorial no Nível Morfossintático.

\subsection{Considerações finais}

Resta-me, para finalizar, realizar um pequeno balanço para avaliar perdas e danos em relação ao compromisso que este trabalho firmou com a fixação de seu objetivo e os 
resultados a que as evidências analisadas permitiram chegar.

Vale lembrar que o principal objetivo deste trabalho foi o de sustentar a tese de que de que há uma variação escalar entre dois extremos. Num haveria construções mais verbais ou completivas plenamente desenvolvidas nucleadas por predicados finitos e, noutro, haveria construções mais nominais ou completivas não-finitas, nucleadas por um predicado codificado como infinitivo ou nominalização.

O continuum que medeia esses dois extremos seria capaz de fornecer um conjunto de construções alternativas, cuja seleção depende crucialmente de motivações funcionais, especialmente as de natureza semântica, como os princípios de iconicidade e economia (HAIMAN, 1983; CRISTOFARO, 2003), com base na natureza semântica do predicado matriz, que se projetariam sobre a codificação morfossintática do predicado encaixado.

Nesse caso, a gradação entre maior ou menor grau de sentencialidade (LEHMANN, 1988), que se define nos interstícios desse continuum, configuraria uma forte relação de integração entre a semântica (GIVÓN, 1980, 1984, 1990) do predicado encaixador e a codificação morfossintática do predicado encaixado. Essa relação de integração estaria, no final, representada formalmente nos níveis e camadas de organização estrutural, definidos pela GDF (HENGEVELD; MACKENZIE, 2008), e se comportaria como uma situação linguística típica de alinhamento representacional.

Se consideradas em termos de frequências preferenciais, as evidências emanadas dos dados analisados sustentaram fortemente essas previsões, o que justificaria alegar que, no final, o balanço aponta mais para uma situação de crédito do que uma de débito. Além disso, as evidências discutidas confirmaram algumas das mais fortes predições funcionalistas. Uma delas é a de que nada na língua é matéria de tudo ou nada, mas de construções escalares que radicalizam ainda mais esse princípio por envolverem alternativas preferenciais não construções únicas e definitivas. 
Além disso, um linguista funcionalmente orientado assume que há motivações sistemáticas, sujeitas a princípios regulares, subjacentes à conexão entre funções semânticodiscursivas e estruturas morfossintáticas relevantes. As motivações são relacionadas ao modo como as estruturas se projetam nos conceitos correspondentes (iconicidade), à frequência e ao grau de acessibilidade dessas estruturas na mente do falante (economia), à dificuldade de processamento de combinações individuais de estruturas e conceitos etc.

O princípio funcional de economia representa uma pressão para a simplificação máxima da expressão. O resultado é, segundo Cristofaro (2003), tornar a estrutura linguística mais opaca em contraposição ao princípio da motivação icônica, que torna a estrutura mais transparente. A economia sintagmática é a tendência para reduzir o comprimento ou a complexidade do enunciado, de modo que as expressões mais frequentes no uso tendem a reduzir-se fonologicamente, e a informação redundante ou recuperável no contexto comunicativo tende a ser omitida.

$\mathrm{Na}$ subordinação completiva, assim como em outros tipos de subordinação, é a economia sintagmática que explica a correlação entre a predeterminação de traços semânticos de estados de coisas ligados e os fenômenos morfossintáticos que levam à não especificação de informação correspondente. Se a referência temporal, aspectual ou modal do estado de coisas dependente é predeterminada pelos traços semânticos do predicado principal, ou pela relação de conexão entre os dois estados de coisas, ela não precisa ser especificada no verbo que codifica o estado de coisas dependente. Similarmente, se os dois estados de coisas compartilham argumentos, também a referência a eles, seja mediante expressão valencial seja mediante concordância de pessoa, pode ser omitida na construção dependente. Quanto maior o grau de compartilhamento entre os eventos da oração matriz e da completiva, tanto maior o grau de integração semântica e, consequentemente, de integração morfossintática. 
Esses resultados estão fortemente arraigados no uso, em evidência empírica rigorosamente levantada. Penso que resultados baseados em evidência derivada do uso da língua, como a que serviu de base para este trabalho, estão muito fortemente propensos a mostrar grau maior de adequação entre teoria e dados. Nesse aspecto, considero que o saldo que ficou também é positivo.

O otimismo que esse balanço gera não significa excluir a discordância do ponto de vista de outros auditores. Muito pelo contrário, quanto mais debate este trabalho suscitar maior prova para seu realizador de que outros pesquisadores não são indiferentes aos seus resultados. Pior que a discordância só a indiferença. Espero que o saldo positivo deste balanço seja a predição otimista de que esta tese continue a suscitar discussão e como todo trabalho de grau seja, como o fenômeno investigado, um continuum, mas num sentido diferente, de estar sempre dialogando com outros textos similares num processo contínuo de elaboração que não se esgota neste ponto final. 


\section{REFERÊNCIAS}

ANSTEY, M. Functional grammar from its inception. In: MACKENZIE, J. L.; GÓMEZGONZÁLEZ, M. Á. (Ed.). A new architecture for Functional Grammar. Berlin: Mouton de Gruyter Amsterdam, 2004. p. 23-72.

AZEREDO, J.C.A. Fundamentos de gramática do português. Rio de Janeiro: Jorge Zahar Editor, 2000.

BASTOS, S. D. G. et al. The expressibility of modality in representational complement clauses in Brazilian Portuguese. In: HATTNHER, M. M. D.; HENGEVELD, K. (Eds.). Advances in Functional Discourse Grammar. Alfa - Revista de Lingüística 51.2, 2007, p.189212.

BECHARA, E. Moderna gramática portuguesa (37 $7^{\mathrm{a}}$ revista, ampliada e atualizada conforme o novo Acordo Ortográfico). Rio de Janeiro: Nova Fronteira, 2009.

BOLKESTEIN, M. Sentential complements in Functional Grammar: Embedded predications, propositions, utterances in latin. In: NUYTS, J., BOLKESTEIN, A. M. \& VET, C. (Eds). Layers and levels of representation in language theory: a functional view. Amesterdam/Philadelphia: John Benjamins, 1990.

. Limits to layering: locatability and other problems. In: FORTESCUE, M et al. (Ed.). Layered structure and reference in a functional perspective. Amsterdam: John Benjamins. 1992. p. 387-407.

BORBA, F. da S. Dicionário gramatical de verbos do português contemporâneo do Brasil. São Paulo: Fundação Editora da UNESP, 1990.

BRAGA, M.L. Relações de complementação sob a perspectiva da Gramática DiscursivoFuncional. In: $56^{\circ}$ Seminário do Grupo de Estudos Linguísticos do Estado de São Paulo GEL. São José do Rio Preto - Brasil, 2008.

BRESNAN, J. On complementisers: Toward a syntactic theory of complement types. Foundationsof Language, n. 6, 1970, p. 297-321.

Theory of complementation in English syntax. New York: Garland, 1979.

BUTLER, C.S. Structure and function: a guide to three major structural-functional theories. Part 2: from clause to discourse and beyond. Amsterdam and Philadelphia: John Benjamins, 2003.

Corpus studies and functional linguistic theories. In: MACKENZIE, J. L.; SIMONVANDENBERGEN, A. M., THOMPSON, G. (eds.). Functions of Language (vol. 11, n. ${ }^{\circ} 2$ ). Amsterdam/Philadelphia: John Benjamins Publishing Company, 2004, p.147-186.

Cognitive adequacy in structural-functional theories of language. Language Sciences. Vol. 30, 2008, p.1-30. 
CEGALLA, D.P. Novíssima gramática da língua portuguesa (48 a edição revisada). São Paulo: Companhia Editora Nacional, 2008.

CUNHA, C.; CINTRA, L. Nova gramática do português contemporâneo. $5^{\mathrm{a}}$ edição. Rio de Janeiro: Lexikon, 2008.

CAMACHO, R.G. Gramática, formalização e discurso. Estudos Linguísticos XXXV. São Carlos, 2006, p. 3-26. Disponível em www.gel.org.br.

O papel da nominalização no continuum categorial. 2009. 275 f. Tese (Livredocência em Linguística) - Instituto de Biociências, Letras e Ciências Exatas - UNESP, São José do Rio Preto, 2009.

CHOMSKY, N. Lectures on government and binding. Dordrecht: Foris, 1981.

Knowledge of language. New York: Praeger, 1986.

COMRIE, B. The syntax of action nominals: a cross-language study. Lingua. Vol. 40, p.177201, 1976.

COMRIE, B; THOMPSON, S.. Lexical nominalizations. In: SHOPEN, T. (ed.) Language typology and syntactic description. Vol. III. Cambridge: Cambridge University Press, 1985, p. 349-398.

CRISTOFARO, S. Subordination. Oxford: University Press, 2003.

CROFT, W. Syntactic categories and grammatical relations: the cognitive organization of information. Chicago: University of Chicago Press, 1991.

Autonomy and functionalist linguistics. Language 71, 1995, p.490-532.

DECAT, M.B.N. Uma abordagem Funcionalista da Hipotaxe Adverbial em Português. In: Série Encontros. Descrição do Português: abordagens funcionalistas. ano XVI, $\mathrm{n}^{\circ} 1$. Araraquara: Unesp, 1999.

DIK, S.C. Formal and semantic adjustment of derived constructions. In: BOLKSTEIN et al. (Ed.). Predicates and terms in Functional Grammar. Dordrecht/Cinnaminson: Foris, 1985, p. $1-28$. $11-52$.

On the notion "functional explanation". Belgian Journal of Linguistics 1. 1986, p.

The theory of Functional Grammar. (Part I: The structure of the clause). Dordrecht: Foris, 1997a.

The theory of Functional Grammar. (Part II: Complex and Derived Constructions). Edited by Kees Hengeveld. Berlin/New York: Mouton de Gruyter, 1997b.

DIK, S.; HENGEVELD, K. The hierarchical structure of the clause and the typology of perception verb complements. Linguistics 29.2, 1991, p. 231-259. 
DILLINGER, M. Forma e função na lingüística. D.E.L.T.A. São Paulo, v. 1991, p. 395-407.

DILLINGER, M. et al. Padrões de complementação no português falado. In:KATO, M.A. (Org.). Gramática do português falado - Volume V: Convergências. Campinas: Editora da UNICAMP, 1996, p. 275-322.

DIXON, R.M.W. Complement clauses and complementation strategies in typological perspective. In: DIXON, R.M.W; AIKHENVALD. A.Y. (Eds). Complementation. Oxford: Oxford University Press, 2006, p.1-48.

DU BOIS, J. W. Competing motivations. In: HAIMAN, J. (ed.). Iconicity in syntax. Amsterdam/Philadelphia: John Benjamins Publishing Company, 1985.

EGAN, T. Non-finite complementation: A usage-based study of infinitive and -ing clauses in English. Amsterdam - New York: Editions Rodopi B.V., 2008.

FABER, P. B.; USÓN, R. M. Constructing a lexicon of English verbs. Berlin: Mouton de Gruyter, 1999.

FOLEY, W.; VAN VALIN, R. Functional syntax and universal grammar. Cambridge: Cambridge University Press, 1984.

FRAJZYNGIER, Z. Grammaticalization of the complex sentence: a case study in Chadic. Amsterdam: John Benjamins, 1996.

GARCIA VELASCO, D. Funcionalismo y Linguística: la Gramática Funcional de S.C. Dik. Oviedo, Universidad de Oviedo, 2003.

GIVÓN, T. The time-axis phenomenon. Language. vol 49, 1973, p. 890-925.

On understanding grammar. New York: Academic Press, 1979.

. The binding hierarchy and the typology of complements. Studies in Language: 4-3, 1980, p. 333-377.

. Syntax I. New York: Academic Press, 1984.

1989.

Mind, code and context: Essays in pragmatics. Hillsdale, NJ: Lawrence Erlbaum,

Syntax: a functional-typological introduction. Amsterdam: John Benjamins, 1990.

English Grammar - a function-based introduction. V. I. Amsterdam /Philadelphia: John Benjamins Publishing Company, 1993.

Company, 1995.

Functionalim and grammar. Amsterdam /Philadelphia: John Benjamins Publishing Syntax: an introduction (Volume I). Amsterdam: Benjamins, 2001a. 
Syntax: an introduction (Volume II). Amsterdam: Benjamins, 2001b.

GONÇALVES, S.C.L. Gramaticalização e dessentencialização de construções com predicados de atitude proposicional. Gragoatá. N. ${ }^{\circ} 21,2^{\circ}$ semestre, 2006, p.147-166.

GONÇALVES, S.C.L. et al. As construções subordinadas substantivas. In: NEVES, M.H.M.; CASTILHO, A.T. (Org.). Gramática do português culto falado no Brasil - Classes de palavras e processos de construção. Campinas: Editora da Unicamp, 2008, p. 1021-1084.

GONÇALVES, S.C.L.; TENANI, L.E. Problemas teórico-metodológicos na elaboração de um sistema de transcrição de dados interacionais: o caso do projeto ALIP (Amostra Lingüística do Interior Paulista). In: RONCARATI, C.; SOARES, V.L. (Orgs). Gragoatá. N. ${ }^{\circ}$ 25, $2^{\circ}$ semestre, 2008, p.165-183.

GRIMSHAW, J. Complement selection and the lexicon. Linguistic Inquiry, v. 2, n.10, 1979, p. 279-326.

HAIMAN, J. Iconic and economic motivation. Language, 59: 1983, p.781-819.

HALLIDAY, M.A.K. An introduction to Functional Grammar. London: Edward Arnold, 1985.

An introduction to Functional Grammar. London: Edward Arnold, 1994a.

. "Systemic Theory". In R. E. Asher \& J. M. Y. Simpson (Eds.). The Encyclopedia of

Language and Linguistics. Oxford: Pergamon Press, 1994b, p.4505-508

An introduction to Functional Gramma. London: Arnold, 2004.

HALLIDAY, M.A.K.; HASAN, R. Cohesion in English. London: Longman Library, 1979.

HALLIDAY, M.A.K., MATTHIESSEN, C.M.I.M. Construing experience through meaning: A language-based approach to cognition. London and New York: Cassell, 1999.

Educational, 2004.

An introduction to Functional Grammar. London: Hodder and Stoughton

HENGEVELD, K. Layers and operators in Functional Grammar. Journal of Linguistics 25, 1989, p.127-157.

The hierarchical structure of utterances. In: NUYTS, J.; BOLKSTEIN, A. M.; VET, C. (eds.). Layers and levels of representation in language theory: a functional view. Amsterdam/Philadelphia: John Benjamins, 1990a, p.1-24.

Semantic relations in non-verbal predication. In: NUYTS, J.; BOLKSTEIN, A. M.; VET, C. (eds.). Layers and levels of representation in language theory: a functional view. Amsterdam/Philadelphia: John Benjamins, 1990b, p.101-122.

. The internal structure of adverbial clauses. In: DEVRIENDT, B.; GOOSSENS, L.; AUWERA, J. van der (eds). Complex structures: A functionalist perspective (Functional 
Grammar Series 17). Berlin: Mouton de Gruyter, 1996, p. 119-147.

Adverbial clauses in the languages of Europe. In: AUWERA, J. van der; BAIOLL, D.P.O. (eds). Adverbial Constructions in the Languages of Europe. Berlim and New York: Mouton de Gruyter, 1998, p.335-419.

The architecture of a Functional Discourse Grammar. In: MACKENZIE, L., GONZÁLEZ, M. G (Eds). A New Architecture for Functional Grammar (Functional Grammar Series 24). Berlin: Mouton de Gruyter, 2004a.

Epilogue. In: MACKENZIE, L., GONZÁLEZ, M. G (Eds). A new architecture for Functional Grammar (FGS 24). Berlin: Mouton de Gruyter, 2004b, p. 365-378.

Dynamic expression in Functional Grammar. In: DE GROOT, C.; HENGEVELD, K. (Ed.) Morphosyntactic Expression in Functional Grammar. Berlin: Mouton de Gruyter, 2005. p.53-86.

HENGEVELD, K.; MACKENZIE, J.L. Functional Discourse Grammar - A typologicallybased theory of language structure. Oxford: Oxford University Press, 2008.

HOPPER, P.J. Emergent grammar. Proceedings of the Berkeley linguistics society 13, 1987, p $139-157$.

Emergence of grammar. In BRIGHT, W. (ed.). International Encyclopedia of Linguistics. New York and Oxford: Oxford University Press, 1992, p.364-367.

HOPPER, P. J. \& THOMPSON, S. A. The discourse basis for lexical categories in universal grammar. Language 60, 1984, p.703-83.

HOPPER, P., TRAUGOTT, E. Grammaticalization. Cambridge: Cambridge University Press, 1993.

HYMES, D. Short notice of Dik's Studies in Functional Grammar. Language in Society, v. $12,1979$.

JACKENDOFF, R. X-bar Syntax. Cambridge, MA: MIT Press, 1977.

KOPTJEVSKAJA-TAMM, M. Nominalization. London/New York: Routledge, 1993.

LABOV, W. Sociolinguistic Patterns . Philadelphia: University of Pennsylvania Press, 1972 .

LAKOFF, R. The pragmatic of Subordination. In: BRUGMAN, C. et al. (Eds.). Proceedings of the Tenth Annual Meeting of the Berkeley Linguistics Society. 1984, p. 481-492.

LANGACKER, R.W. Foundations of Cognitive Grammar. Vol. I: Theoretical Prerequisites. Standford: Standford University Press, 1987a. Nouns and verbs. Language 71, 1987b. p.1-62.

Foundations of Cognitive Grammar. Vol II: Descriptive Applications. Stanford: Stanford University Press, 1991. 
LEHMANN, C. Towards a tipology of clause linkage. In: HAIMAN, J.; THOMPSON, S.A. (Eds.). Clause combining in grammar and discourse. Amsterdam: John Benjamins, 1988.

LYONS, J. Semantics (vol 2). Cambridge: Cambridge University Press, 1977.

MACKENZIE, J. L. Nominalization and valency reduction. In: BOLKESTEIN, A. M. et al. (eds). Predicates and terms in Functional Grammar. Dordrecht/Cinnaminson: Foris, 1985, p. $31-51$.

English nominalizations in the layered model of the sentence. In: DEVRIEND, B., GOOSSENS, L., AUWERA, J. von der (eds). Complex Structures: A Functionalist Perspective. Berlim/New York: Mouton de Gruyter, 1996, p.325-55.

MALCHUKOV, A. L. Nominalization/verbalization: constraining a typologyt of transcategorial operations. Lincom: Lincom Europa, 2004.

MATEUS, M.H.M. et al. Gramática da língua portuguesa. Coimbra: Almedina, 1983.

Gramática da língua portuguesa. 5. ed. Lisboa: Caminho, 2003.

MATTHIESSEN, C.; THOMPSON, S. The structure of discourse and "subordination". In: HAIMAN, J.; THOMPSON, S. (Eds). Clause combining in grammar and discourse. Amsterdam: John Benjamins, 1988, p. 275-329.

MIOTO, C.; KATO, M.A. Aspectos sintáticos da subordinação sentencial. In: ABAURRE, M.B.M; RODRIGUES, A.C.S. (orgs). Gramática do português falado - Volume V: Convergências. Campinas: Editora da UNICAMP, 2002, p. 379-411.

NASCIMENTO, M.do. Teoria gramatical e "Mecanismos funcionais do uso da língua". D.E.L.T.A. São Paulo, v. 6., n. 1, 1990, p.83-98.

NEVES, M.H.M. Discurso e gramática no funcionalismo. In: Estudos Lingüísticos, v. 28, 1999, p.30-40.

NEVES, M.H.M. Gramática de usos do Português. São Paulo: Editora da UNESP, 2002

NEWMEYER, E.F. Some remarks on the Functionalist-Formalist controversy in linguistics. In: DARNELL, M. et al. (Ed.) Functionalism and Formalism in Linguistics. Amsterdam: John Benjamins, 1998. p.469-486 (V. 2: Studies in Language Companion Series 42).

NOONAN, M. Complementation. In: SHOPEN, T. (Ed.) Language typology and syntactic description. Vol II: Complex constructions. 1985, p. 42-141.

NUYTS, J. Aspects of a cognitive-pragmatic theory of language. Amsterdam: John Benjamins, 1992.

OUHALLA, J. Functional categories and parametric variation. London: Blackwell, 1981.

PERINI, M. A. Gramática descritiva do português. São Paulo: Ática, 1995. 
ROSENBAUM, P. S. The grammar of English predicate complement constructions. Cambridge: MIT Press, 1967.

SAID ALI, M.I. Gramática histórica da língua portuguesa. 8. ed. São Paulo/Brasília: Melhoramentos/ UnB, 2001.

SANKOFF, D. VARBRUL: Université de Montréal. 1975 (mimeo)

SOUSA, G.C. Gramaticalização das construções com orações completivas: o caso do complemento oracional introduzido por se. Araraquara, 2007. Tese (Doutorado em Linguística e Língua Portuguesa) - Faculdade de Ciências e Letras de Araraquara - UNESP.

STASSEN, L. Comparison and Universal Grammar. Oxford: Basil Blackwell, 1985.

STOWELL, T. Subjects across categories. The Linguistic Review, 2 (3), 1982, p.285-312.

VAN VALIN, R.D. Exploring the syntax-semantics interface. Cambridge: Cambridge University Press, 2005.

A typology of syntactic relations in clause linkage. In: BRUGMAN, C. et al. (Eds.). Proceedings of the Tenth Annual Meeting of the Berkeley Linguistics Society. 1984, p. 54258.

VAN VALIN, R.D., LAPOLLA, R.J. Syntax: structure, meaning and function.Cambridge: Cambridge University Press, 1997.

VILELA, M. Gramática da língua portuguesa. 2. ed. Coimbra: Almedina, 1999.

VOTRE, S.J., NARO, A. J. Mecanismos funcionais do uso da língua. D.E.L.T.A. (São Paulo). v. 5., n. 2, 1989, p. 169-184. 
Autorizo a reprodução xerográfica para fins de pesquisa.

São José do Rio Preto, 18 de fevereiro de 2010.

\section{LILIANE SANTANA}

